RICARDO PERES FREOA

\title{
DO CONTRATO DE PARTICIPAÇÃO EM GRUPO DE CONSÓRCIO PARA AQUISIÇÃO DE BENS OU SERVIÇOS
}

DISSERTAÇÃO DE MESTRADO EM DIREITO CIVIL

Orientador: Professor Doutor Alcides Tomasetti Júnior

Faculdade de Direito da Universidade de São Paulo

São Paulo

2014 


\section{RICARDO PERES FREOA}

\section{DO CONTRATO DE PARTICIPAÇÃO EM GRUPO DE CONSÓRCIO PARA AQUISIÇÃO DE BENS OU SERVIÇOS}

Dissertação de mestrado em Direito Civil sob a orientação do Professor Doutor Alcides Tomasetti Júnior.

Faculdade de Direito da Universidade de São Paulo

São Paulo

2014 
BANCA EXAMINADORA 


\section{AGRADECIMENTOS}

Agradeço aos meus pais, Walter e Christiane, por me sempre me ensinarem amorosamente que a única maneira de enfrentar tempos críticos, ferozes, difíceis de manejar, é pelo amor incondicional aos outros, a integridade aos valores e constante busca pelo conhecimento, pelo entendimento, pelo discernimento e pela sabedoria como uma vital empreitada para encontrar tesouros escondidos. Em todos os momentos da minha vida, bons ou ruins, meus pais sempre foram minha força protetora, minha companhia e, principalmente, meus melhores amigos.

Agradeço também ao Professor Doutor Alcides Tomasetti Júnior, que desde os tempos de graduação tenta iluminar os cantos escuros do mundo jurídico por meio do estudo da filosofia, da sociologia e da economia, introduzindo-me ao pensamento de Pontes de Miranda e modelos dogmáticos de pensamento com elevado grau de abstração, mas de fundamental utilidade na compreensão dos fenômenos jurídicos. Sou muito grato por todo o esforço do Professor em não apenas passar conhecimento, mas dar um limite, uma finalidade clara para aplicação quase matemática dos conceitos, compartilhando seu modo particular de enxergar o mundo jurídico.

Não posso deixar de agradecer a Fabiano Marques Milani, André Mestriner Stocche, Bruna Pires de Campos Belloto e a todos os colegas do escritório que sempre fizeram o possível e o impossível para me apoiar durante toda a pesquisa, fornecendo, além do seu tempo e companheirismo, imensa vontade de discutir e contribuir o desenvolvimento do trabalho.

Muitas palavras de agradecimento podem ser dirigidas a meus colegas Roberto Panucci Filho e Paulo Henrique Signori Pinese, que me aguentaram durante a graduação e pós-graduação e sempre estiveram prontos para contribuir com este trabalho de maneiras incontáveis, seja compartilhando as angústias e alegrias do trabalho de pesquisa, seja por trazerem constantes novidades que exigiram permanente renovação e validação do pensamento e da compreensão do fenômeno objeto deste estudo.

Por fim, quero deixar registrado meu sincero muito obrigado a Marcel Simões, a Leonardo Auriema e Júlio César Alves, amigos que se mostraram verdadeiros irmãos em tempo de aflição, com um apoio inestimável sem o qual o trabalho não seria concluído. Sem dúvida, a gratidão será eterna. 


\section{DEDICATÓRIA}

A Camila Salina Bertan por me ensinar a enxergar a beleza nas pequenas coisas e a descobrir como amar de toda alma, de toda mente e de todo coração. 
"A nós, juristas, impõe-se a tarefa mais difícil: crer na profissão de nossa vida, e, concomitantemente, em alguma das camadas mais profundas de nossa essência, duvidar dela todo o tempo".

\section{Gustav Radbruch}




\section{RESUMO}

A Lei n. ${ }^{\circ}$ 11.795/08 trouxe nova disciplina ao mecanismo do consórcio, originário da prática diária e utilizado para lidar com falta generalizada de crédito e com a galopante inflação, transformado agora em um sistema amplo, reconhecido como instrumento de progresso social que se destina a propiciar o acesso ao consumo de bens e serviços. O consórcio é tratado socialmente como agrupamento de sujeitos reunidos para o levantamento ao longo do tempo de recursos financeiros a serem aplicados na aquisição de bens ou serviços da mesma espécie, em quantidade correspondente ao número de membros do grupo. Sob a óptica da dogmática jurídica, a gênese de toda a disciplina do consórcio concentra-se no contrato de participação em grupo de consórcio, definido legalmente como "instrumento plurilateral de natureza associativa cujo escopo é a constituição de fundo pecuniário para a finalidade de propiciar a seus integrantes, de forma isonômica, a aquisição de bens ou serviços, por meio de autofinanciamento". O objeto deste estudo consiste na busca da compreensão do sistema de consórcios por meio da classificação e da qualificação jurídica do contrato de participação em grupo de consórcio.

Palavras-chave: consórcio, contrato, associativo, consumo, organização 


\begin{abstract}
Law n. 11.795/08 has brought about a new understanding to consortium, which was initially developed by interested parties to remedy the general lack of credit and raging inflation and, is now transformed into a consortia system known as a social development instrument to facilitate the consumption of goods and services. Consortium is considered to an aggroupment of parties so gathered to raise financial resources to, in time, be used in the procurement of goods or services of the same nature, in a corresponding quantity to the number of members of the group. Under the perspective of legal doctrine, the genesis of all consortium related discipline is concentrated on the contract of participation on a consortium, which legal definition is "a plurilateral associative document aiming to constitute a monetary fund to, isonomically, allow its participants to acquire goods or services by self-financing". The subject matter of this study is the search for comprehension about the consortia by the classification and legal qualification of the contract of participation on a consortium.
\end{abstract}

Key words: consortium, contract, associative, consumption, organization 


\section{SUMÁRIO}

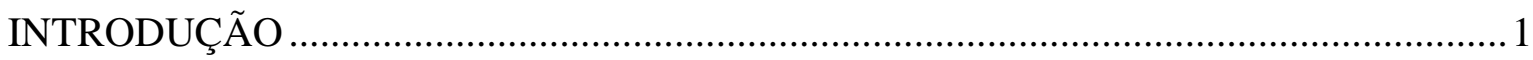

1. NOÇÕES GERAIS DE CONTRATO DE PARTICIPAÇÃO EM GRUPO DE CONSÓRCIO E DO SISTEMA DE CONSÓRCIOS .......................................................

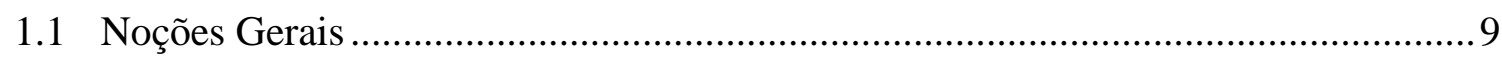

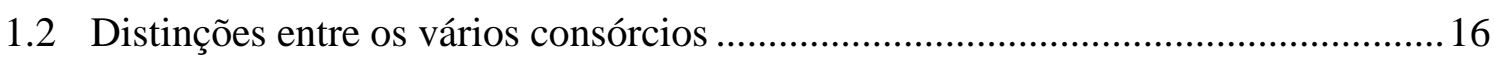

1.3 Apontamentos históricos do desenvolvimento do consórcio no Brasil .................... 19

1.1.1. Possíveis antecedentes históricos do consórcio ..............................................20

1.1.2. A evolução da disciplina do consórcio no Brasil ..........................................25

2. O FUNCIONAMENTO PRÁTICO DO CONSÓRCIO ................................................. 37

2.1. A sociedade administradora de grupos de consórcio ........................................... 37

2.2. Contrato de participação em grupo de consórcio ................................................. 40

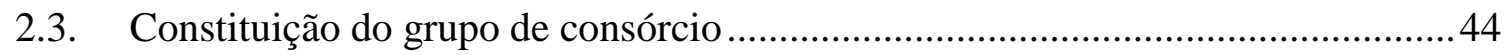

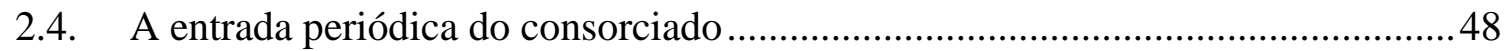

2.4.1. Cálculo da entrada mensal para o fundo comum ..........................................50

2.4.2. Cálculo do valor da taxa de administração mensal .......................................50

2.4.3. Cálculo do valor da entrada mensal para o fundo de reserva ........................51

2.4.4. Cálculo do valor mensal de desembolso do consorciado ..............................51

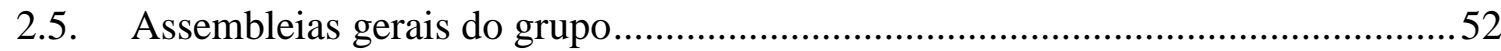

2.6. Diferenças na entrada periódica do consorciado.................................................53

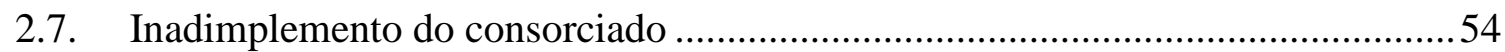

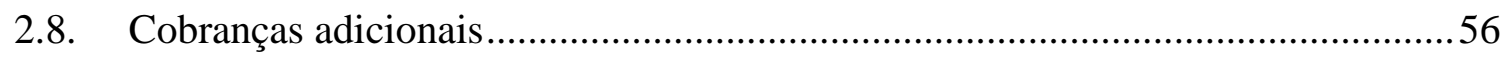

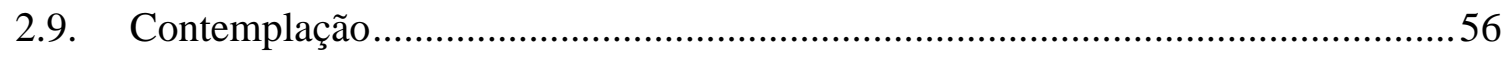

2.10. Utilização do crédito pelo consorciado ............................................................58

2.11. Exclusão do grupo e desistência do consorciado ............................................59

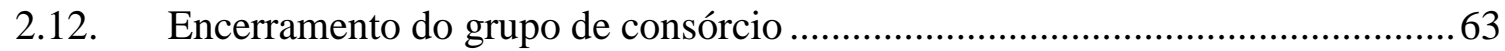

3. ANÁLISE ESTRUTURAL DOS FATOS JURÍDICOS: O PLANO DA EXISTÊNCIA, O PLANO DA VALIDADE E O PLANO DA EFICÁCIA ........................65

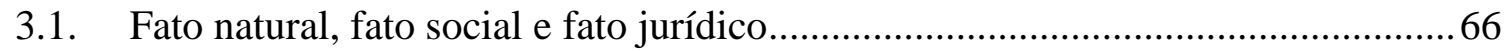

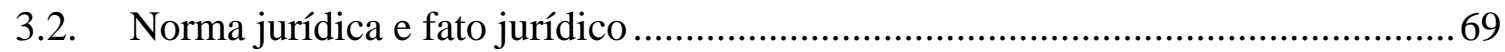

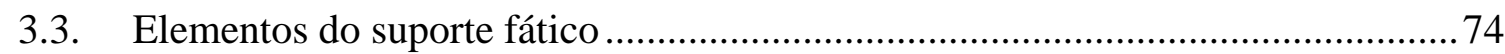

3.4. A incidência da norma jurídica sobre o suporte fático....................................... 77 
3.5. O fato jurídico e suas espécies ..........................................................................79

3.6. Suporte fático suficiente, suporte fático deficiente e suporte fato eficiente ..........81

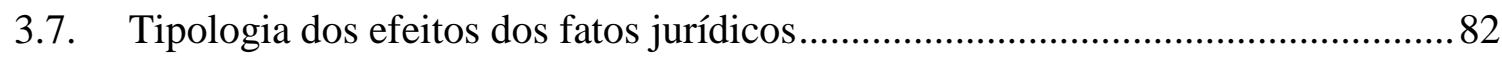

4. CLASSIFICAÇÃO E QUALIFICAÇÃO DO CONTRATO DE PARTICIPAÇÃO EM

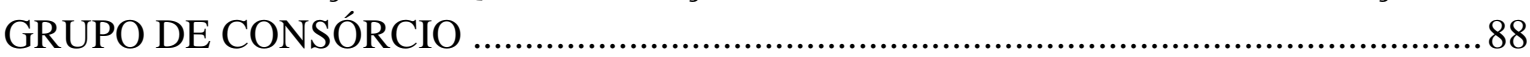

4.1. Noções gerais do contrato de participação em grupo de consórcio …………….......8 88

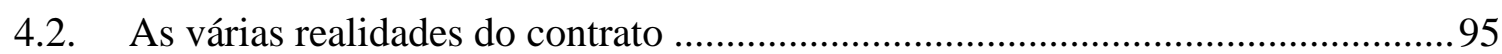

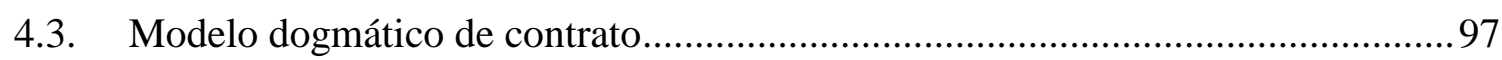

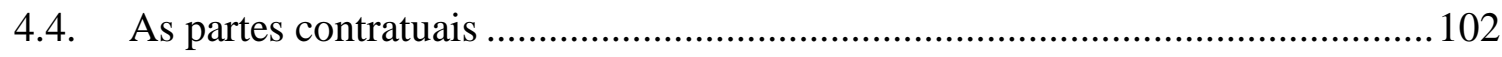

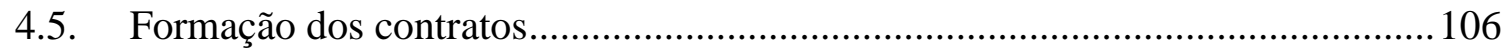

4.6. As classificações dos contratos .......................................................................113

4.6.1. Classificação dos contratos pela sua função econômica..................................114

4.6.2. Contratos reais e contratos consensuais ........................................................ 116

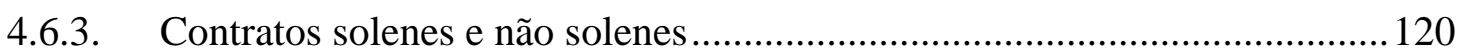

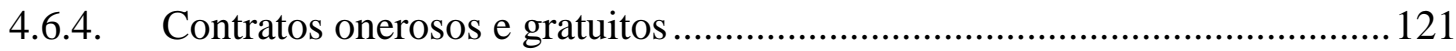

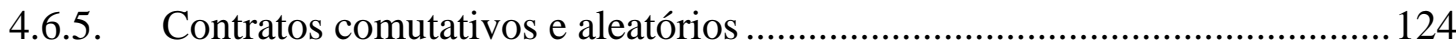

4.6.6. Contratos de prestações correspectivas, contratos de prestação de uma parte, contratos de prestações para consecução de escopo comum .......................................125

4.6.7. Contratos de comunhão de escopo e contratos organizativos.........................130

4.7. Análise do contrato de participação em grupo de consórcios a partir das

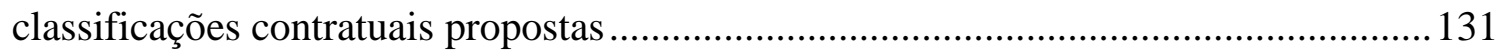

4.8. Processo de conclusão do contrato de participação em grupo de consórcio........146

4.9. Consentimento por adesão e contrato por adesão ……………………………...... 150

4.10. Classificação do contrato de participação em grupo de consórcio .....................154

4.11. Impossibilidade de qualificação do contrato de participação em grupo de

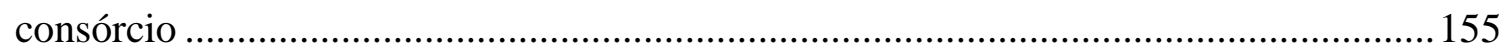

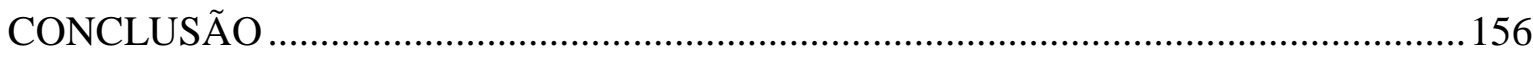

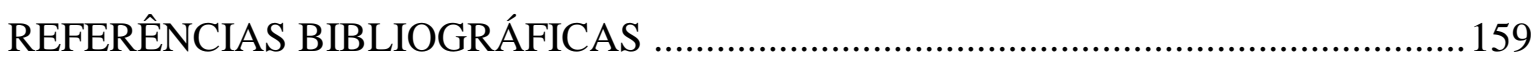




\section{INTRODUÇÃO}

O fenômeno identificado por Z. BAUMAN ${ }^{1}$ de liquidificação da sociedade pósmoderna apresenta-se cada vez mais claro, pois os sólidos laços humanos que outrora constituíram os pilares da vida social estão cada vez mais frágeis, mais globalizados, mais padronizados e o desenvolvimento tecnológico, ao mesmo tempo em que permite em larga escala o contato praticamente instantâneo entre pessoas ${ }^{2}$ em extremos opostos da superfície terrestre, também banaliza tais contatos sociais. De fato, as conexões entre pessoas são desfeitas com a mesma facilidade com que são criadas: basta apertar um botão, girar uma alavanca, escorregar os dedos sobre a tela de um dispositivo móvel para criar novos laços e conexões, renovar o ciclo de amigos e, por que não, de namorados, cônjuges e companheiros. Esta mudança de uma sociedade sólida para uma sociedade líquida resulta em tensões, rupturas e quebras de valores compartilhados pelos membros de determinada sociedade. Com efeito, a sociedade moderna ${ }^{3}$ era marcada pela busca de liberdade em um meio social considerado como um local seguro, edificado sobre os fundamentos da repressão, da imposição, do policiamento e da coação. Embora valorizassem essa sensação de segurança social, as pessoas buscavam, ainda que de maneiras particulares, um maior grau de liberdade, uma possibilidade para a satisfação de seus desejos e necessidades ${ }^{4}$.

A sociedade pós-moderna, com seus laços humanos liquefeitos, por sua vez, continua a coexistir com o mesmo conflito segurança-liberdade, mas paulatinamente experimenta uma inversão no sentido do gládio, pois o valor máximo da sociedade líquida é a liberdade: todos são e devem ser livres ao extremo, respeitado tão somente o padrão

1 Cf. Z. BAUMAN, Amor líquido - sobre a fragilidade dos laços humanos, trad. port. Carlos Alberto Medeiros, Rio de Janeiro, Zahar, 2004, p. 15 e s.

2 Nesta subseção o vocábulo pessoa é empregado em sentido ético-social e não em seu sentido técnico-jurídico de ente autônomo de imputação de posições jurídicas subjetivas ativas e passivas (Cf. M. Bernardes De Mello, Teoria do fato jurídico - Plano da Eficácia - 1. ${ }^{a}$ parte, 2. ${ }^{a}$ ed., São Paulo, Saraiva, 2004, pp. 125-162; A. TomASETTI JR., Teoria Geral do Direito Privado, mimeo, São Paulo, 2004).

3 A expressão "sociedade moderna" não é empregada no texto em seu sentido técnico-histórico com relação à sociedade típica da chamada Idade Moderna. Esta se caracterizava pela divisão estamental da sociedade (clero, nobreza e resto), a centralização do poder político nas mãos do monarca e o consequente fortalecimento - e até criação - dos estados nacionais. No texto, "sociedade moderna" refere-se ao conceito tradicional de estrutura social iniciada com a revolução industrial e que atingiu seu clímax no final do século 19 e na primeira metade do século 20.

4 Cf. S. Freud, $O$ mal-estar na civilização, 2. a ed., Coimbra, Relógio D’Água, 2008. Sob a teoria econômica, o modelo de análise da conduta humana assume que a verdadeira força motriz do ser humano e a base dos conflitos intersubjetivos não é a necessidade natural, mas os desejos profundos imanentes ao homem (ver, por todos, M. C. JENSEN - W. H. MECKLING, The Nature of Man, Journal of Applied Corporate Finance, vol. 7, n. ${ }^{\circ}$ 2, 1994, pp. 4-19). 
mínimo e móvel de convivência. Surgem muitas liberdades, inúmeros grupos sociais diminutos que bradam expressões como "multiculturalismo" e "aceitação das diferenças" que resultam na mais importante forma de licença social, a liberdade de conexão e desconexão com qualquer pessoa ou grupo.

Onde antes faltava liberdade e sobrava segurança agora não passa de um sítio de liberdade extrema, de forma que o grande medo, o verdadeiro mal-estar que assola a sociedade pós-moderna não é mais a repressão, a carência de liberdade. A marca indelével da sociedade líquida atual é exatamente a opção pela liberdade exacerbada em detrimento da segurança e, por isso, os medos e os temores das pessoas pós-modernas se encontram em um lugar comum, um ponto de partida e também de chegada denominado insegurança 5 . Não é possível enfrentar essa insegurança com armas, muros, grades ou sistemas de alarmes, visto que a incerteza instalou-se como hóspede indesejada nos fundamentos dos próprios relacionamentos humanos. Como a insegurança não pode ser derrotada por uma atuação individual, a psique humana precisa sublimar seus temores com algo mais próximo e palatável, como o esquecimento momentâneo da insegurança por meio da satisfação dos desejos, satisfação essa que, na sociedade pós-moderna, só é obtida pelo consumo ${ }^{6}$. A vida é, portanto, orientada para o consumo ${ }^{7}$. Deveras, o consumo é a válvula de escape da sociedade pós-moderna, uma vez que quem consome exercita sua liberdade, reivindica sua condição de cidadão num mundo que valoriza o que a pessoa tem e não o que a pessoa é. Afinal, a possibilidade de consumir bens ou serviços é a única segurança, a única imutabilidade de uma sociedade líquida, cujos laços humanos são jogados de um lado para o outro pelas ondas dos modismos e a maré da tecnologia.

Em mundo no qual a principal fonte de segurança, ainda que momentânea, é o consumo, nada mais natural do que a transformação de tudo (e todos) em bens para consumo. Contudo, tal transformação não é suficiente para prover bens em quantidade e qualidade passíveis de satisfazer necessidades e desejos, porque, como é a premissa inicial de todo o pensamento econômico, os bens colocados no mercado de consumo são

5 Cf. Z. BAUMAN, O mal-estar da pós-modernidade, trad. port. Mauro Gama, Cláudia Martinelli Gama, Rio de Janeiro, Zahar, 1999, p. 37.

6 A vida das pessoas é orientada para busca de uma impossível segurança em um mundo de liberdade insegura; face à impossibilidade de encontrar a segurança tão deseja, a necessidade de segurança metamorfoseia-se em necessidade de consumir.

$7 \quad$ Cf. Z. BAUMAN, Vida para o consumo - a transformação das pessoas em mercadoria, trad. port. Carlos Alberto Medeiros, Rio de Janeiro, Zahar, 2008, p. 43. 
escassos $^{8}$. Em razão da relação entre escassez e aptidão para satisfação de necessidades e desejos $^{9}$, os bens para consumo são passíveis de valoração econômica e consequente expressão pecuniária, cabendo ao Direito, em especial ao Direito Privado, utilizando a poderosa técnica da relação jurídica, proceder à ordenação dos bens entre os sujeitos.

Face ao evidente caráter patrimonial, o consumo depende da titularidade de meios de pagamento, ou, mais tecnicamente, de moeda corrente nacional, que também é escassa. Há titulares superavitários de recursos monetários enquanto outros necessitam destes mesmos recursos (= sujeitos deficitários), o que em qualquer sociedade, mas principalmente em uma sociedade orientada para o consumo, torna imprescindível a criação de mecanismos que permitam a transferência dos recursos dos sujeitos superavitários para os sujeitos deficitários e que, após receberem os recursos, poderão empregá-los em seus objetivos próprios. Em outras palavras, é preciso criar mecanismos de financiamento ${ }^{10}$. Fomentar o consumo, então, passa a ser atribuição do Estado, pois o consumo total, ou melhor, a demanda agregada, relaciona-se diretamente ao crescimento macroeconômico e ao desenvolvimento nacional ${ }^{11}$. No caso brasileiro atual, a política macroeconômica adotada depende do consumo total das famílias brasileiras, baseada em três pilares de sustentação: (1) metas de inflação; (2) responsabilidade fiscal; e (3) câmbio flutuante. A correta combinação desses mecanismos de política macroeconômica, associados a uma política prudencial adequada e forte supervisão, resultaram na capacidade de absorver choques internos e externos, na estabilidade macroeconômica e financeira, na possibilidade de crescimento sustentável, no desenvolvimento dos mercados de crédito e de capital e, por fim, aumento do investimento em todos os setores da economia.

Em anos recentes, verificou-se significativa melhora nos índices de diversos fundamentos macroeconômicos, tais como crescimento da renda, redução das taxas de

8 Cf. E. G. MANKIW, Introdução à economia, 5. a ed., trad. port. Allan Vidigal Hastings, Elisete Paes e Lima, ver. téc. Carlos Roberto Martins Passos, Manuel José Nunes Pinto, São Paulo, Cengage Learning, 2009, pp. 3-4, para quem a economia é o estudo de como a sociedade administra os recursos escassos.

$9 \quad$ A relação de complementaridade entre o sujeito que experimenta uma necessidade e o ente apto a satisfazer tal necessidade consiste, consoante lição de F. CARNELUTTI, no conceito de interesse (Teoria Generale del Diritto, 3. ${ }^{a}$ ed. Roma, Foro Italiano, 1951, p. 11 e ss.). Para uma súmula das diversas concepções de interesse na literatura jurídica, vide P. MOTA PINTO, Interesse Contratual Negativo e Interesse Contratual Positivo, v. 1, Coimbra, Coimbra, 2008, p. 481 e seguintes.

10 A palavra "financiamento" é empregada no texto em sentido amplíssimo, entendido como o ato de obter recursos para determinado objetivo (Cf. F. J. MASSET LACOMBE, Dicionário de negócios - mais de 6.000 termos em inglês e português, São Paulo, Saraiva, 2009, p. 289)

${ }_{11}$ Cf. J. M. KEYNES, The General Theory of Employment, Interest and Money, New York, Martino Fine Books, 2011. 
desemprego e maior formalização dos contratos de trabalho, que somando à redução das taxas de juros, gera forte estímulo ao processo de inclusão financeira e expansões expressivas nas carteiras de crédito, com destaque para o crédito imobiliário. De fato, o crédito ao consumidor possui suma importância no desenvolvimento econômico ${ }^{12}$, pois, conforme sustenta R. LEVINE ${ }^{13}$, um sistema financeiro bem estruturado deve apresentar cinco mecanismos básicos para atuação direta na atividade econômica: (1) produção antecipada de informações sobre possíveis investimentos e alocação de capital; (2) monitoramento de investimento e utilização de mecanismos de governance do tomador dos recursos; (3) facilitação da troca, diversificação e administração de riscos; (4) mobilização e constituição de poupança; e (5) facilitação da aquisição e troca de bens e serviços.

Com relação ao primeiro mecanismo, deve-se atentar para o inegável custo para obtenção de informações sobre os diversos investimentos e agentes econômicos, tendo em vista que a assimetria de informações ${ }^{14}$ incrementa os custos de negociação entre os agentes (transaction costs) e aumenta os riscos de comportamento oportunista por parte daqueles dotados de mais informações ${ }^{15}$. O segundo mecanismo apontado por R. LEVINE, desenvolvimento de instrumentos que permitam monitorar o tomador dos recursos, também são fundamentais para assegurar o uso ótimo dos recursos, reduzir os custos de oportunidade e aumentar a eficiência econômica como um todo. No tocante à administração de risco (mecanismo 3), os fatores fundamentais são a diversificação de risco entre diversos setores (cross seccional), o compartilhamento intertemporal do risco e a distribuição do risco de liquidez. Diversificam-se os riscos por meio de investimentos em portfólios bem diferentes, seja em projetos individuais, atividades empresariais, setores econômicos e até regiões de determinado país ou continente. Embora choques sistêmicos possam frustrar a mitigação do risco pela diversificação dos investimentos, é possível

12 Para uma análise histórica do papel do crédito financeiro no desenvolvimento dos países, vide $\mathrm{N}$. FERGUSON, The Ascent of Money - a Financial History of the world, New York, Penguin, 2009.

13 R. LEVINE, Finance and Growth - Theory and Evidence, in P. AGHION - S. DURLAF (eds.), Handbook of economic growth, v.1, Amsterdam, North-Holland, 2006.

14 Em economia, assimetria de informação entre duas partes envolvidas em determinada transação ou relacionamento econômico se refere à situação em que uma das partes detém informação que, se fosse de conhecimento da outra parte, faria com que esta mudasse seu comportamento, cf. H. R. VARIAN, Intermediate Microeconomics, 6. ${ }^{\mathrm{a}}$ ed. New York, Norton, 2003, p. 668.

15 De acordo com a teoria econômica, o oportunismo é característica marcante da ação humana nas relações sociais, e se caracteriza como a busca do interesse próprio com utilização do engodo, do erro e ou da ignorância, consoante exposição O. E. WILlIAMSON: "Mais genericamente, o oportunismo se refere à apresentação incompleta ou distorcida de informações, especialmente a esforços calculados para enganar, distorcer, fingir, ofuscar ou de outro modo confundir" (The economic institutions of capitalismo, New York, Free Press, 1985, p. 47, tradução livre do original: "More generally, opportunism refers to the incomplete or distorted disclosure of information, especially to calculated efforts to mislead, distort, disguise, obfuscate, or otherwise confuse"). 
compartilhar tais riscos entre as gerações. Investimentos de longo prazo que ofereçam retornos razoáveis no período de crescimento econômico e retorno elevado em momentos de crise sistêmica permitem compartilhar os riscos no tempo e, consequentemente, garantem a higidez do sistema no longo prazo. Por fim, os riscos de liquidez podem ser devidamente tratados se há a disponibilidade imediata de moeda corrente para os poupadores enquanto os agentes de intermediação investem em ativos não circulantes. $\mathrm{O}$ quarto mecanismo do sistema financeiro é a mobilização da poupança popular, mas para que as pessoas possam poupar, guardar e investir os recursos excedentes às suas despesas e consumo, é preciso um ambiente institucional que permita superar: (1) os custos de negociação (transaction costs) decorrentes da coleta de poupança de diversos sujeitos; e (2) a assimetria informacional para fazer com que os sujeitos se sintam seguros em abrir mão da gestão sobre seus recursos. Último mecanismo do sistema financeiro, a facilitação de trocas depende de instituições que reduzam os custos de negociação (transaction costs) pela maior especialização produtiva, informacional e operacional, tendo em vista que, como mostrou ADAM SMITH, quanto maior a divisão do trabalho (especialização), maior o grau de eficiência produtiva ${ }^{16}$.

Há relação direta entre o consumo e os mecanismos 4 e 5, pois se tais mecanismos forem bem empregados, resultarão na expansão do consumo. É por isso que qualquer análise a respeito do sistema de consórcios, ou mais propriamente, do contrato de participação no grupo de consórcio deve levar em conta tais mecanismos, pois o sistema de consórcios desempenha macro função de captação e mobilização da poupança popular e de redução dos custos de negociação (transaction costs). Destarte, é essencial que sejam necessidade de serem desenvolvidos mecanismos que permitam a expansão do consumo e o acesso das pessoas ao crédito é possível compreender o desenvolvimento histórico do consórcio na realidade brasileira.

Dentro os mecanismos de incentivo à captação da poupança popular, incentivo ao consumo e planejador da atividade de investimento, destaca-se o consórcio como uma operação tipicamente brasileira, surgida no seio social e ganhando aos poucos posição de relevo nas políticas financeiras, principalmente na política monetária, do Estado brasileiro. Tradicionalmente, o consórcio é visto como agrupamento de sujeitos reunidos para o levantamento ao longo do tempo de recursos financeiros a serem aplicados na aquisição de 
bens ou serviços da mesma espécie, em quantidade correspondente ao número de membros do grupo $^{17}$.

A participação do sistema de consórcios na economia nacional vem crescendo sensivelmente, com 5,63 milhões de consorciados ativos em outubro de 2013, correspondendo ao dobro do verificado em 2000, quando somou 2,81 milhões de consorciados. Nos últimos treze anos, o crescimento do consórcio se consolidou e diversificou a participação nos vários segmentos: veículos automotores, 86,8\%, que, com sua totalidade subdividida, apresenta $49 \%$ em motocicletas, $46,6 \%$ em veículos leves e 4,4\% em veículos pesados; tendo ainda os imóveis com 12,3\%; eletroeletrônicos e outros bens duráveis com $0,6 \%$ e serviços com $0,3 \%$. Os consórcios também apontaram expansão nas vendas de novas cotas e nas contemplações, com 2,09 milhões de novas adesões nos dez primeiros meses de 2013 e aumento de 3\% no número de contemplações, de 1,01 milhão (jan-out/2012) para 1,04 milhão (jan-out/2013), no mesmo período ${ }^{18}$.

Atualmente, o consórcio ganhou o status de sistema um microssistema disciplinado pela Lei n. ${ }^{\circ} 11.795$, de 8 de outubro de 2008 (Lei 11.795/08) e pelas normas específicas do Banco Central do Brasil, mormente a Circular n. ${ }^{\circ}$ 3.432, de 4 de fevereiro de 2009, a Circular n. ${ }^{\circ} 3.433$, de 3 de fevereiro de 2009 e a Circular n. ${ }^{\circ} 3.558$ de 16 de setembro de 2011. Assim, de acordo com o art. 2. ${ }^{\circ}$ da Lei 11.795/08, consorcio é "a reunião de pessoas naturais e jurídicas em grupo, com prazo de duração e número de cotas previamente determinados, promovida por administradora de consórcio, com a finalidade de propiciar a seus integrantes, de forma isonômica, a aquisição de bens ou serviços, por meio de autofinanciamento". Compõe-se o chamado sistema de consórcio pelo grupo de consórcio, definido como "sociedade não personificada constituída por consorciados" (art. 3. ${ }^{\circ}$ da Lei 11.795/08), e pela sociedade administradora de grupos de consórcio, "pessoa jurídica prestadora de serviços com objeto social principal voltado à administração de grupos de consórcio, constituída sob a forma de sociedade limitada ou sociedade anônima" (art. 5. ${ }^{\circ}$ da Lei 11.795/08). Cabe ao Banco Central do Brasil normatizar, supervisionar, fiscalizar e controlar as atividades do sistema de consórcio de consórcios (art. 6. ${ }^{\circ}$ da Lei 11.795/08). Dentre as competências do Banco Central, vale destacar a autorização para funcionamento, transferência de controle e realização reorganização societária envolvendo a

17 Cf. A. RizzARDO, Contratos, 5. ${ }^{\text {a }}$ ed. Rio de Janeiro, Forense, 2005, p. 1279.

18 Cf. ASSOCIAÇÃO BRASILEIRA DAS ADMINISTRADORAS DE CONSÓRCIO, total de consorciados dobra em Treze anos e é recorde histórico, 2013, Disponível em < http://abac.org.br/sistemas/releases/1_(201312052342)MATERIA_DE_DEZEMBRO_2013_DADOS_DE_ OUTUBRO_DE_2013_A_29nov2013_FINAL.pdf> 
administradora de consórcios (art. 7. ${ }^{\circ}$, inciso I da Lei 11.795/08). A Lei 11.795/08 reconhece no sistema de consórcios, um papel destacado como "instrumento de progresso social que se destina a propiciar o acesso ao consumo de bens e serviços". Cada consórcio é em si um microssistema composto "por administradoras de consórcio e grupos de consórcio", e os vários consórcios existentes estão organizados pelo Banco Central em um sistema mais amplo, um sistema de consórcios que integra o integra o Sistema Financeiro Nacional (SFN) ${ }^{19}$

Sob a óptica da dogmática jurídica, a gênese de toda a disciplina do consórcio concentra-se no contrato de participação em grupo de consórcio, definido legalmente como "instrumento plurilateral de natureza associativa cujo escopo é a constituição de fundo pecuniário para a finalidade de propiciar a seus integrantes, de forma isonômica, a aquisição de bens ou serviços, por meio de autofinanciamento" (art. $10 \mathrm{c} / \mathrm{c}$ art. 2. ${ }^{\circ}$ da Lei 11.795/08). Desse modo, uma das melhores maneiras de compreender o sistema de consórcios é estudar o contrato de participação em grupo de consórcios, procurando classifica-lo e qualifica-lo dentro dos modelos dogmáticos. Não obstante, como se mostrará ao longo do estudo, autores que se dedicaram ao estudo do contrato de participação em grupo de consórcio o fizeram como um meio para atingir um fim maior, como a possibilidade de devolução imediata das entradas feitas pelo consorciado excluído ou desistente. Também existem estudos focados na aplicação do Código de Defesa do Consumidor à relação entre administradora do grupo de consórcios e os consorciados, estudos esses que acabam por focar tanto nessa relação que se ignora por completo a dicção legal no sentido de que o contrato é, acima de tudo, celebrado entre os consorciados para a formação de fundo comum cujos recursos serão aplicados periodicamente na aquisição do bem ou do serviço em favor do consorciado contemplado. Outros autores sustentam que o contrato de participação em grupo de consórcio é um contrato atípico, porque a legislação preocupou-se mais em disciplinar a operação econômica do consórcio do que as relações jurídicas completas.

Assim, a proposta do presente estudo é compreender o funcionamento do sistema de consórcios por meio da classificação jurídica desse contrato, o que envolverá a análise de pertinência a determinado grupo contratual, sendo os grupos repartidos com base na

19 E. FORTUNA admite, implicitamente, o sistema de consórcios como integrante do Sistema Financeiro Nacional ao inserir as administradoras de consórcios como "instituições não financeiras, mas participantes do mercado financeiro", dentro do subsistema de intermediação (FORTUNA, Eduardo. Mercado Financeiro: produtos e serviços. 18. ed. Rio de Janeiro: Qualitymark, 2010. p. 18). 
verificação ou ocorrência de certas características ou qualidades adotadas como critérios distintivos. Ademais, tendo em vista a noção atual de que o contrato de participação em grupo de consórcio é atípico, guardando notas da sociedade, da associação e do mandato, será feita a tarefa de tentar qualificar o contrato, procurando identificar se contrato é um contrato de sociedade ou um contrato de compra-e-venda, a partir de um pensamento tipológico dos tipos enquanto modelos regulatórios de sentido próprio e imanente. Tanto a tarefa de classificação como de qualificação demandam um conhecimento profundo do conteúdo contratual e da operação econômica subjacente ao contrato. Desse modo, o presente estudo iniciará na primeira seção trazendo as noções gerais sobre a ideia da operação de consórcio, diferenciando-a de outras figuras consorciais e traçando os antecedentes históricos. É cediço que a operação de consórcio como é conhecida hoje surgiu no âmbito de servidores do Banco do Brasil na década de 1960 que buscavam fugir das altas taxas de juros e da inflação galopante. Entender as evoluções e involução da disciplina do consórcio será fundamental para entender o sistema os diversos interesses a serem organizados pelo contrato de participação em grupo de consórcio.

Após a análise das noções gerais e do desenvolvimento histórico, da estática do consórcio, a segunda seção procurará descrever em termos simples a dinâmica de funcionamento do consórcio no dia a dia, permitindo enxergar o desenvolvimento completo da operação econômica do consórcio. Antes de adentrar profundamente à classificação do contrato de participação em grupo de consórcio, a seção três fixará os conceitos metodológicos centrais que serão utilizados na análise do fenômeno consorcial, em especial a teoria do fato jurídico de F. C. PONTES DE MiRANDA e a teoria das posições jurídicas subjetivas elementares proposta por W.N. HoHFELD, G. LUMIA e A. TOMASETTI JR. Com base nos conceitos fixados, a seção final procurará classificar o contrato de participação em grupo de consórcio dentro dos diversos modelos dogmáticos de contrato, comparando o modelo legal com o modelo socialmente adotado, visto que a prática não raro se afasta da teoria.

Ressalta-se que não serão analisados aspectos relacionados com o Direito do Consumidor, abstraindo-se, exceto em poucas incursões, de seus impactos nas conclusões adotadas. 


\section{NOÇÕES GERAIS DE CONTRATO DE PARTICIPAÇÃO EM GRUPO DE CONSÓRCIO E DO SISTEMA DE CONSÓRCIOS}

O objeto desta seção é permitir a compreensão do conteúdo semântico da palavra consórcio, com os diversos aspectos por ela evocados, e os contornos gerais do sistema de consórcio no qual o contrato objeto de estudo está inserido, passando pela evolução do sistema na realidade brasileira e compreendendo esquematicamente o funcionamento prático do consórcio no dia a dia das famílias brasileiras.

\subsection{Noções Gerais}

O vocábulo consórcio deriva da palavra latina consortium, com o significado literalmente de "comunhão de sortes, ou sorte comum" 20 . No direito romano pré-clássico, existia a figura do consortium ercto non cito, uma espécie de propriedade coletiva acidental entre os coerdeiros do pater famílias presente na economia agrária que marcou as primitivas eras do desenvolvimento da civilização romana ${ }^{21}$, conforme explica Gaio:

\footnotetext{
"antigamente, quando morria o chefe da família [lit.: o pater famílias], formavase entre os herdeiros naturais uma espécie de sociedade simultaneamente legítima e natural, a que se dava o nome de ercto non cit $^{\prime 22}$.
}

Ou seja, com a morte do pater famílias, os bens herdados passavam a ser de propriedade comum da família, sem que nenhum herdeiro fosse titular individual de uma quota ou quinhão sobre a herança, mas todos os direitos eram atribuídos à comunhão de

20 Consortium é formado por cum, que exprime a ideia de "companhia, sociedade, junção no tempo ou no espaço, qualificação, maneira de ser ou de estar, acompanhamento e consequência", e do verbo latino sortis, a "ação de tirar à sorte coisas atadas entre si".

$21 \quad$ Cf. Consortium, in Enciclopédia Saraiva de Direito, v. 18, São Paulo, Saraiva, 1978, p. 296.

22 G. 3. 154a, in Instituições - direito privado romano, trad. e notas J. A. Segurado e Campos, Lisboa, Calouste Gulbenkian, 2010, p. 340. Conforme explica R. ZIMMERMANN, a referência de Gaio no G.3.154 a uma sociedade pertencente ao direito das gentes gerava um acalorado debate na doutrina acerca da existência de uma sociedade pertencente ao direito civil. Nesse sentido, a descoberta de um fragmento das Instituições em uma loja de livros usados no Cairo em fevereiro de 1933 confirmou as suspeitas ao mencionar o consortium ercto cit e a societas omnium bonorum (in The Law of Obligations - Roman Foundations of the Civilian Tradition, Cape Town/Wetton/Johannesburg, Juta, 1992, pp. 451-452). 
herdeiros $^{23}$, o que permitia atender a anseios de solidariedade social, garantir proteção em situações de guerras e conservar a unidade familiar como veículo propulsor do expansionismo romano, pois era exclusivo dos cidadãos romanos e regido pelo ius civile ${ }^{24}$.

Pondera R. ZIMMERMANN que o consortium ercto cit teve um papel fundamental na construção da identidade familiar romana, impedindo que a morte do chefe da família levasse à decomposição da unidade familiar em tantas novas famílias quanto fossem os herdeiros. Pelo contrário, a morte do pater famílias mantinha os herdeiros unidos em uma comunhão de coerdeiros, que mantinha a antiga família tanto para fins sagrados quanto jurídicos ${ }^{25}$.

O consortium, isto é, a comunhão de sortes, era decorrente da propriedade coletiva indivisível sobre os bens herdados, de modo que a expressão "ercto non cit" é traduzida consistentemente pelos romanistas como "propriedade não divisível”, embora para alguns, como o próprio GAIO, “erctum significa 'propriedade', termo donde provém erus, que significa 'senhor'; quanto a ciere, significa dividir",26, enquanto para outros como V. ARANGIO-RUIZ, ercto vem de ercisco, que significa "dividir" e cit deriva de cieo, que significa provocar ${ }^{27}$.

Em seus traços históricos originais, então, o consortium era uma imposição "natural" da impossibilidade de divisão da herança pelos coerdeiros, inexistindo decisão por parte dos integrantes da comunhão de herdeiros sobre a permanência ou não deste estado consorcial. Pode-se dizer o consortium ercto non cit pode ser definido como um "consórcio hereditário",28.

A despeito do "consórcio hereditário", GAIO também menciona outra espécie de consórcio, que podia ser formada pela decisão de irmãos e outros parentes de explorarem bens em conjunto por meio de uma ação perante o pretor, in verbis:

23 Cf. R. Zimmermann, The Law of Obligations - Roman Foundations of the Civilian Tradition, Cape Town/Wetton/Johannesburg, Juta, 1992, p. 452.

24 Cf. Del ChiARo, Le Contrat de Société en Droit Privé Romain sous la République et au Temps des Jurisconsultes Classiques, Paris, Sirey, 1928, p. 20.

${ }_{25} \quad$ Cf. The Law of obligations cit., p. 452; E. PETIT, Tratado Elementar de Direito Romano, trad. port. J. L. Custódio Porto, adap. R. Rodrigues Gama, Campinas, Russell, 2003, p. 541.

$26 \quad$ G. 3. 154a, in Instituições - direito privado romano cit., p. 340.

27 Cf. V. ARANGIO-RuIZ, La società in Diritto Romano, Napoli, Jovene, 1950, p. 3, nota 1.

28 Cf. R. VENTURA RIBEIRO, Aspectos da societas Romana, in Revista da Faculdade de Direito da Universidade de São Paulo, v. 101, jan./dez. 2006, p. 629. A ideia de um consórcio hereditário, ou, mais propriamente, uma comunhão hereditária, não é estranha ao ordenamento jurídico brasileiro, visto que o art. 1.791 do Código Civil enuncia norma por meio da qual a "herança defere-se como um todo unitário, ainda que vários sejam os herdeiros", caracterizando-se esse todo unitário pela indivisibilidade das posições jurídicas dos coerdeiros até o momento da partilha. 


\begin{abstract}
"Outros [herdeiros] que o desejassem, igualmente podiam formar também uma sociedade do mesmo tipo, para o que deviam recorrer ao Pretor mediante uma bem determinada acção da lei. Neste tipo de sociedade, formada por irmãos e por outros [parentes] que, à maneira dos irmãos, quisessem formar entre si uma sociedade, verificava-se esta peculiaridade: um dos sócios [que o quisesse] podia conceder liberdade por manumissão a um escravo comum, o qual passaria a ser liberto de todos. Igualmente, se um [dos sócios] fizesse a venda de um bem comum tornava [esse bem] propriedade por mancipação daquele que o adquirisse" 29
\end{abstract}

Supõe-se que o consortium voluntarium surge após a Lei das XII Tábuas, visto que então a herança passa a ser divisível por meio da actio familiae erciscundae e a continuidade da comunhão depende então do consentimento dos herdeiros ${ }^{30}$.

Além do elemento consenso, aponta R. VENTURA RIBEIRO que outra diferença fundamental entre os dois tipos de consórcio reside no fato de que o consortium voluntarium surge desde logo no âmbito do ius gentium, disponível, portanto, não apenas aos cidadãos romanos ${ }^{31}$.

Por meio do consortium voluntarium ${ }^{32}$, os consorciados unificavam todas as suas posições jurídicas ativas e passivas, independentemente de sua origem, formavam uma comunhão universal na busca de uma finalidade comum ${ }^{33}$. Em sua evolução histórica, o consortium voluntarium pautava-se inicialmente no consenso entre os familiares e posteriormente no consenso entre quaisquer pessoas, mesmo sem relação familiar entre si. Surgia, assim, a estrutura jurídica e social para o desenvolvimento da sociedade ${ }^{34}$, caracterizada pela necessidade de consenso permanente, nas relações pessoais entre os membros, fortes vínculos de confiança, relação fraternal (ius quodammodo fraternitatis), o

29 G. 3. 154b, in Instituições - Direito Privado Romano cit., pp. 340-341.

30 Cf. V. ARANGIO-RuIZ, La società cit., p. 14. E. PETIT menciona que, após a divisão da herança, cada herdeiro era arrolado no censo com o seu quinhão, de maneira que uma das vantagens do consortium voluntarium era a manutenção de todos os participantes como titulares da totalidade dos bens da herança (Tratado Elementar de Direito Romano cit., p. 531).

31 Cf. Aspectos da societas Romana cit., p. 629. Contra, R. ZIMMERMANn, The Law of Obligations, para quem o consortium voluntarium era exclusivo dos cidadãos romanos por meio do ius civile.

$32 \quad$ Cf. R. VENTURA RIBEIRO, Aspectos da societas cit., p. 629.

33 Cf. R. ZIMMERMANN, The Law of Obligations cit., p. 452.

34 Cf. R. ZIMMERMANN, The Law of Obligations cit., p. 453, florescimento do comércio e dos empreendimentos que exigiam maior aplicação de recursos eram incompatíveis com a comunhão universal do consortium voluntarium, de modo que no final da República o pretor peregrino passou a reconhecer acordos voltados a um fim comum restrito a algumas atividades ou até a uma única operação. Com o passar do tempo, o consortium voluntarium e esta figura de sociedade reconhecida pelo direito pretoriano fundiramse na societas clássica. A ideia de que o contrato de sociedade da era clássica desenvolveu-se a partir do consortium ercto cit não é pacífica, conforme pode ser verificado na resenha compilada por R. VENTURA RIBEIRO, Aspectos da societas cit., pp. 630-636. 
beneficium competentiae e a extinção da sociedade pela morte ou capitis deminutio do sócio $^{35}$.

Aparentemente, o emprego da palavra consórcio em língua portuguesa data de 1540 EC, com a palavra consórcio utilizada como sinônimo de casamento ou matrimônio e, com o passar do tempo, no sentido figurado de união, combinação, associação ou comunicação de pessoas ${ }^{36}$. Em seu Vocabulario Portuguez \& Latino, de 1728, R. BluTEAU definiu consórcio como "companhia, sociedade, união" ${ }^{37}$, sendo que companhia significa "pessoas juntas em algum lugar", "pessoas unidas entre si por qualquer fim que seja", "pessoas que vivem juntas", "pessoas que comem e bebem na mesma casa"38, a sociedade a "união" ou "aliança" entre pessoas 39 e a união o ajuntamento de coisas diversas do qual resulta uma só ${ }^{40}$. A. DE MORAES SILVA, por sua vez, entendia o consórcio como "companhia entre consortes", "sociedade", "conversação"41. A companhia era definida como "união de pessoas ou cabedais para algum fim", "união para fim de convivência ou conversação", "sociedade",42 e o consorte como "o companheiro na sorte, no estado ou na fortuna, o marido ou a mulher" $"$. A sociedade era "a união de duas ou mais pessoas para conseguirem algum fim", o sócio "o companheiro de outro ou de mais que se concertarão para de mão comum conseguirem algum fim"44 e a união "o ajuntamento de várias peças em hum todo", "ajuntamento em hum corpo", "uniformidade" e "adhesão"45. Por força da evolução semântica do vocábulo, o vernáculo contemporâneo admite cinco acepções básicas da palavra consórcio ${ }^{46}$ : (1) associação, união; (2) união matrimonial, casamento; (3) convivência, companhia; (4) grupo de sociedades autônomas que têm operações comuns; e (5) grupo de pessoas que assumem o compromisso formal de pagar mensalmente uma prestação para uma caixa comum, destinada à compra futura de um

35 Cf. R. Ventura RiBEIRO, Aspectos da societas cit., pp. 635-636

36 Cf. Consórcio, in Dicionário Houaiss da Língua Portuguesa, Rio de Janeiro, Objetiva, 2009, p. 530.

37 R. Bluteau, Vocabulario Portuguez \& Latino - aulico, anatomico, architectonico ..., v. 2, Coimbra, Collegio das Artes da Companhia de Jesu, 1728, p. 481.

$38 \quad$ R. BluteaU, Vocabulario Portuguez \& Latino cit., vol. II, p. 412.

39 R. Bluteau, Vocabulario Portuguez \& Latino cit., vol. VII, p. 684.

$40 \quad$ Cf. R. Bluteau, Vocabulario Portuguez \& Latino cit., vol. VIII, p. 551.

41 A. Moraes SILVA, Diccionario da Lingua Portugueza - Recompilado dos Vocabularios Impressos ate Agora, e Nesta Segunda Edição Novamente Emendado e Muito Acrescentado, por Antonio de Moraes Silva, 2. ${ }^{a}$ ed., Lisboa, Typographia Lacerdina, 1813, vol. I, p. 453.

$42 \quad$ A. Moraes Silva, Diccionario da Lingua Portugueza cit., vol. I, p. 425.

43 A. Moraes Silva, Diccionario da Lingua Portugueza cit., vol. I, p. 453; em sentido semelhante vide L. M. DA SILva PINTO, Diccionario da Lingua Brasileira por Luiz Maria da Silva Pinto, natural da Provincia de Goyaz, Na Typographia de Silva, 1832, p. 125.

$44 \quad$ A. Moraes Silva, Diccionario da Lingua Portugueza cit., v. II, p. 713.

45 A. Moraes Silva, Diccionario da Lingua Portugueza cit., v. II, p. 821; L. M. DA SILVA PINTO, Diccionario da Lingua Brasileira cit., p. 135.

$46 \quad$ Cf. Consórcio, in Dicionário Houaiss cit., p. 530. 
bem, cujas unidades serão entregues paulatinamente a cada um dos consorciados, a intervalos estipulados, mediante sorteio e/ou lance.

Percebe-se nitidamente que todas as acepções da palavra conservam o elemento união ou ajuntamento e o elemento fim comum no cerne semântico, permitindo uma aproximação da ideia geral de consórcio como o ajuntamento de sujeitos formando um todo unitário para o atingimento de determinado fim comum, compartilhando todos os membros desse ajuntamento das venturas e desventuras resultantes da busca em comum dessa finalidade, conforme explica F. C. PONTES DE MIRANDA:

\begin{abstract}
“Consórcio, senso largo, é a ligação ou associação de pessoas físicas ou jurídicas para atender a necessidades ou interesses dos figurantes. Supõe-se, no conceito, que haja identidade de situação objetiva dos figurantes, ditos consorciados, de modo que a finalidade seja melhor solução para as atividades. Idêntico há de ser o interêsse ou necessidade e idêntica a situação objetiva. Nem sempre é o único meio para a solução dos problemas que resultam da situação objetiva idêntica. A vinculação é para que se atinja o que pareceu realizável (ou somente realizável) com $a$ consorcialidade. O consórcio pode obter o que se quis mediante simples medidas concernentes à atividade de todos os figurantes, ou por distribuição, proporcionável ou não, de atuação. O que importa é que exista comunhão de interesses e que se não destrua ou liminarmente se fira essa comunhão de interesses. Tão-pouco, que se crie comunhão de interesses, porque então a figura seria outra. Parte-se do que existe, estabelecem-se as vinculações, e organiza-se a atividade para o fim consorcial ou para os fins consorciais. A positividade dos atos do consórcio é, se não integral, prevalecente ${ }^{47}$ ".
\end{abstract}

O sentido amplo da palavra consórcio no vernáculo faz com que o universo jurídico conheça muitos consórcios, como o consórcio de sociedades, o consórcio público, o consórcio administrativo, o consórcio imobiliário e o consórcio para aquisição de bens ou obtenção de serviços ${ }^{48}$. Não obstante, o foco do presente estudo é o consórcio constituído para a aquisição de bens de consumo ou a obtenção de serviços, conforme a quinta acepção acima referida, cujo conceito estipulativo é encontrado no art. $2 .^{\circ}$ da Lei 11.795 , de 8 de outubro de 2008 (Lei n. ${ }^{\circ}$ 11.795/08):

\footnotetext{
“Consórcio é a reunião de pessoas naturais e jurídicas em grupo, com prazo de duração e número de cotas previamente determinados, promovida por administradora de consórcio, com a finalidade de propiciar a seus integrantes, de forma isonômica, a aquisição de bens ou serviços, por meio de autofinanciamento".
}

$47 \quad$ Tratado de Direito Privado, vol. LI, 2. ${ }^{\text {a }}$ ed., Rio de Janeiro, Borsoi, § 5.379, n. 2, p. 205

48 Cf. D. Orfali GIacomini, A Devolução das Quantias Pagas pelos Consumidores Desistentes e Excluídos dos Contratos de Consórcio à Luz da Lei 11.795/2008, Dissertação, São Paulo, 2010, p. 19; 
Do conceito estipulativo legal algumas ideias ressaltam, como a reunião de pessoas naturais ou coletivas, a finalidade de propiciar a aquisição de bens ou de serviços de qualquer natureza, o autofinanciamento e participação da administradora de consórcio. Referido conceito está em linha com a evolução da regulamentação do Banco Central do Brasil a respeito do consórcio e com a visão tradicional no campo do Direito do consórcio como agrupamento de sujeitos reunidos para o levantamento ao longo do tempo de recursos financeiros a serem aplicados na aquisição de bens ou serviços da mesma espécie, em quantidade correspondente ao número de membros do grupo ${ }^{49}$.

Apesar do conceito legal de consórcio caminhar na trilha aberta pela doutrina tradicional, na toada do desenvolvimento da regulação do Banco Central do Brasil, os estudos contemporâneos sobre a Lei 11.795/2008 contêm críticas à demasiada atenção que o legislador pátrio concedeu à ideia de reunião e de autofinanciamento, visto que " $o$ consórcio não é uma 'reunião' e muito menos um mecanismo de 'autofinanciamento'”, rejeitando-se a ideia de reunião "porque os consorciados não se reúnem livremente: são 'reunidos' pela administradora do grupo de consórcio”, e afasta-se o conceito de autofinanciamento pelo fato de que "são estes consorciados que 'financiam' o grupo, ou seja, que bancam a coletividade de consorciados que possui o mesmo objetivo, qual seja, adquirir um mesmo bem ou serviço de consumo" 50.

Uma vez afastada a ideia de reunião do núcleo do fenômeno consorcial, para autores como F. FERNANDES Ribeiro MAIA ${ }^{51}$ e MARIA HELEna Diniz ${ }^{52}$, o consórcio é, acima de tudo, um sistema social dotado de elementos e de regras próprias, estruturado a partir da cooperação de vários sujeitos na formação de uma poupança coletiva para aquisição programada de bens ou serviços, com inexistência de juros e ausência de pressão

49 Cf. A. Rizzardo, Contratos, 5. ${ }^{a}$ ed., Rio de Janeiro, Forense, 2005, p. 1279; A. CHAVES, Tratado de direito civil, vol. II, t. II, 3. a ed., São Paulo, Revista dos Tribunais, 1984, pp. 1.386 e ss. O conceito adotado pela Lei 11.795/2008 está pautado no definição do art. 2. ${ }^{\circ}$ da Lei 11.795/2008 no art. $1 .^{\circ}$ do Regulamento anexo à Circular do Banco Central do Brasil n. ${ }^{\circ}$ 2.766/1997: "Consórcio é uma reunião de pessoas físicas elou jurídicas, em grupo fechado, promovida pela administradora, com a finalidade de propiciar a seus integrantes a aquisição de bem, conjunto de bens ou serviço turístico por meio de autofinanciamento".

50 F. FERnANDES RibeIRo MAIA, O Sistema de Consórcio Financeiro na Lei 11.795/2008, Revista de Direito Bancário e do Mercado de Capitais, vol. 47, Jan / 2010, p. 66.

51 Cf. F. FERNANDES RIBEIRO MAIA, Consórcio financeiro - o Sistema e o Pedido de Restituição do Consorciado na Falência da Administradora, Dissertação de mestrado, Belo Horizonte, Universidade Federal de Minas Gerais, 2007, p. 160.

52 Cf. MARIA Helena Diniz, Tratado teórico e prático dos contratos, vol. IV, 6 a ed., São Paulo, Saraiva, 2006, p. 262. 
inflacionária decorrente do espaçamento da demanda dos consorciados ao longo da duração do grupo de consórcio.

Outra concepção merecedora de atenção constrói o consórcio como uma operação de captação de poupança popular dentro de um grupo fechado de sujeitos e que tem por finalidade a aquisição de bens ou serviços de qualquer natureza, sustentada por A. M. SousA FiguEIREDO ${ }^{53}$ e adotada pelo Banco Central do Brasil em sua página eletrônica na rede mundial de computadores ${ }^{54}$.

Embora aparentemente semelhante com a concepção do consórcio enquanto operação econômica, C. H. ABRÃO propõe em estudo monográfico enxergar o consórcio como um empreendimento, empregando a palavra "empreendimento", apesar de não esclarecer a carga semântica utilizada, no sentido de organização decorrente de um contrato por adesão celebrado entre os consorciados e a administradora do grupo de consórcio, acrescentando que referido contrato pode ser qualificado como solene, oneroso, comutativo, com finalidade própria e com termo final de eficácia fixado desde o momento de sua conclusão ${ }^{55}$.

Como é possível verificar, as posições acima referidas concentram no aspecto econômico-finalístico do consórcio, deixando a análise jurídica em segundo plano, apesar do esforço de C. H. ABRÃO de relacionar o empreendimento no âmago do consórcio com o contrato por adesão ${ }^{56}$. O foco no elemento econômico-finalístico é fruto da complexidade do fenômeno, gerador de certo estranhamento para o jurista, como pode ser exemplificado pela concepção de F. UlHOA COELHO fundada no consórcio enquanto "negócio" por meio do qual "uma das partes (administradora) presta determinados serviços às outras (consorciados)", sob um regime de mutualidade, e com a finalidade de viabilizar " $a$ aquisição por cada um dos consorciados [...] de bem móvel, imóvel ou serviços" ${ }^{\$ 7}$. Referido estranhamento no raciocínio fica hialino no emprego vacilante da palavra

$53 \quad A B C$ do Consórcio - Teoria e Prática, 5. ${ }^{\circ}$ ed., Curitiba, Juruá, 2009, p. 32: “Consórcio é uma operação de captação de poupança popular entre um determinado grupo fechado de pessoas, com a finalidade de aquisição de bem móvel ou imóvel, conjunto de bens ou serviços de qualquer natureza".

${ }_{54}$ Introdução ao Sistema de Consórcios, disponível na rede mundial de computadores em < http://www.bcb.gov.br/>: "[O consórcio é uma] operação de captação de recursos em um grupo fechado de pessoas, jurídicas ou físicas, com a finalidade de aquisição de bens ou serviços específicos, por meio de autofinanciamento".

${ }_{55}$ Do consórcio, Rio de Janeiro, GZ, 2010, p. 5: "Define-se, pois consórcio, como o empreendimento assentado no contato de adesão pactutado entre os consorciado e a administradora, solene, oneroso, existentes obrigações recíprocas, de duração limitada, e com especificidade no seu propósito".

56 Vale ressaltar o entendimento de R. SENISE LISBOA no sentido de encarar o consórcio como um contrato (Manual de direito civil, vol. III, 3. ${ }^{\text {a }}$ ed., São Paulo, Revista dos Tribunais, 2005, p. 593).

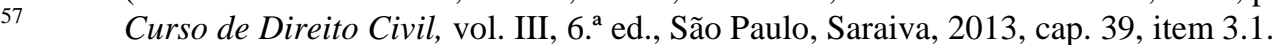


"negócio", gerando uma ambiguidade insolúvel entre o conceito técnico-jurídico de negócio como uma espécie de fato jurídico ou a acepção ordinária de ajuste comercial ou operação econômica.

Em face da dificuldade dos autores na qualificação jurídica do consórcio, evocando o conteúdo finalístico e os elementos econômicos estruturantes para explicar a superestrutura jurídica, qualquer tentativa de aproximação inicial da noção demanda tangenciar o tecido social e a finalidade do consórcio. Assim, para fins de delimitação de noção inicial do objeto estudado, sem qualquer pretensão de esgotamento do fenômeno, o consórcio apresenta-se como um conjunto sistemático de operações econômicas estruturadas para possibilitar a diversos sujeitos, de maneira isonômica e programa ao longo do tempo, a titularidade de um crédito contra um fundo em comum, formado pelas entradas periódicas desses mesmos sujeitos, à prestação de entrega e transferência de certo valor em moeda a um terceiro como contraprestação pela aquisição de um bem, móvel ou imóvel, ou prestação de um serviço de qualquer natureza. Sob a ótica macroeconômica, o mecanismo do consórcio nas linhas acima traçadas permite a formação de poupança popular, estimulando e viabilizando o consumo a partir de uma demanda programada capaz de reduzir e até neutralizar os efeitos inflacionários normalmente decorrentes do aumento da demanda agregada. Observando o sistema pela lente social, o consórcio inclui um elevado número de pessoas na dignificante prática do consumo, dotando-os dos recursos financeiros necessários para fazerem valer sua cidadania na sociedade liquefeita orientada para o consumo.

Apesar de não ser o objeto deste estudo, o forte conteúdo semântico da palavra consórcio, evocando a ideia de união e ajuntamento, exige a diferenciação do consórcio para aquisição de bens duráveis ou obtenção de serviço das demais modalidades de consórcios reconhecidas e disciplinadas no ordenamento jurídico brasileiro.

\subsection{Distinções entre os vários consórcios}

Além do consórcio para aquisição de bens duráveis ou obtenção de serviços de qualquer natureza, o direito brasileiro conhece os consórcios de sociedades, os consórcios 
públicos, os consórcios administrativos e os consórcios imobiliários ${ }^{58}$, todos estruturando alguma forma de união de sujeitos ou de bens para o atingimento de determinada finalidade específica, com caráter conformador, pois o regime jurídico de cada consórcio é edificado a partir das finalidades abstratas de cada união de sujeitos ou bens.

A primeira e mais conhecida modalidade de consórcios é o consórcio de sociedades previsto na Lei n. ${ }^{\circ}$ 6.404, de 15 de dezembro de 1976 (Lei n. ${ }^{\circ}$ 6.404/76) como um ajuntamento entre sociedades para a execução de determinado empreendimento (art. $278^{59}$ ). Comumente, denomina-se consórcio de sociedades o negócio jurídico plurilateral organizativo de direito empresarial e de eficácia patrimonial, consistindo em contrato de comunhão de escopo por meio do qual as partes organizam a colaboração temporária e limitada entre elas, conservando a individualidade jurídica e econômica, para a execução de determinado empreendimento ${ }^{60}$. Também se emprega o termo consórcio de sociedades para designar o conjunto de efeitos decorrentes do contrato de consórcio ${ }^{61}$. As diferenças entre o consórcio de sociedades e consórcio para aquisição de bens ou obtenção de serviços ficam evidentes, inexistindo a figura legal de um terceiro administrador do consórcio ${ }^{62}$, a formação necessária de um fundo comum que será destinado à aquisição do bem ou obtenção do serviço por um dos consorciados, enquanto os demais aguardaram a sua vez. Nada impede que o empreendimento comum a ser desenvolvido entre as sociedades consorciadas seja a aquisição de determinado bem ou a obtenção de certo serviço. Mas isso não transforma o consórcio de sociedades em consórcio para aquisição de bens ou obtenção de serviços, visto que o bem adquirido será pertencente a todos os consorciados em condomínio ou comunhão ou será atribuído contratualmente a apenas uma das partes, o

$58 \quad$ Cf. D. Orfali Giacomini, A Devolução cit., p. 18.

59 "Art. 278. As companhias e quaisquer outras sociedades, sob o mesmo controle ou não, podem constituir consórcio para executar determinado empreendimento, observado o disposto neste Capítulo.

$\S 1^{\circ} \mathrm{O}$ consórcio não tem personalidade jurídica e as consorciadas somente se obrigam nas condições previstas no respectivo contrato, respondendo cada uma por suas obrigações, sem presunção de solidariedade. $\S 2^{\circ}$ A falência de uma consorciada não se estende às demais, subsistindo o consórcio com as outras contratantes; os créditos que porventura tiver a falida serão apurados e pagos na forma prevista no contrato de consórcio".

$60 \quad$ Cf. A. XAVIER, Consórcio: Natureza Jurídica e Regime Tributário, Revista Dialética de Direito Tributário, n. 64, p. 7; F. C. PONTES DE MIRANDA, Tratado de Direito Privado cit., t. LI, § 5.386, n. 1, p. 231-232; M. Rodrigues PENTEAdO, Anotações sobre o consórcio de empresas, Dissertação, Faculdade de Direito da Universidade de São Paulo, São Paulo, 1978; F. Konder ComPARATO, Estudos e Pareceres de Direito Comercial, Rio de Janeiro, Forense, 1978, p. 223; A. AzEvedo Franco Neto, Consórcio, in A. LAmy FILHo - J. L. Bulhões PedreIRA, Direito das Companhias, vol. II, Rio de Janeiro, Forense, 2009, p. 2.073 .

61 Cf. F. C. Pontes de MiRAndA, Tratado de Direito Privado cit., t. LI, § 5.387, n. 3, p. 236-237.

62 O contrato de consórcio de sociedades pode prever a atribuição da administração do consórcio a um terceiro, mas a lei apenas exige que o contrato contenha cláusulas tratando da administração. 
que é diametralmente diferente do mecanismo e da finalidade do consórcio objeto deste estudo.

Também não se confunde com o consórcio para aquisição de bens ou obtenção de serviços o consórcio público previsto no art. 241 da Constituição Federal ${ }^{63}$ e disciplinado pela Lei n. ${ }^{\circ}$ 11.107, de 6 de abril de 2005 (Lei n. ${ }^{\circ}$ 11.107/05), caracterizado pelo negócio jurídico de direito administrativo celebrado por dois ou mais entes federativos para a constituição de uma nova pessoa jurídica de direito público ou privado (art. $6 .^{\circ}$ da Lei n. ${ }^{\circ}$ $11.107 / 05^{64}$ ) com objeto de gerir os serviços públicos de interesse comum das partes (art. 1. ${ }^{\circ}$ e art. $2 .^{\circ}$ da Lei n. $\left.{ }^{\circ} 11.107 / 05^{65}\right)$.

Os consórcios administrativos, por sua vez, são disciplinados pela Lei n. ${ }^{\circ}$ 8.666, de 21 de junho de 1993 (Lei n. ${ }^{\text {o }}$ 8.666/1993) e podem ser constituídos entre entidades da

63 “Art. 241. A União, os Estados, o Distrito Federal e os Municípios disciplinarão por meio de lei os consórcios públicos e os convênios de cooperação entre os entes federados, autorizando a gestão associada de serviços públicos, bem como a transferência total ou parcial de encargos, serviços, pessoal e bens essenciais à continuidade dos serviços transferidos".

$64 \quad$ "Art. $6^{\circ} \mathrm{O}$ consórcio público adquirirá personalidade jurídica:

I - de direito público, no caso de constituir associação pública, mediante a vigência das leis de ratificação do protocolo de intenções;

II - de direito privado, mediante o atendimento dos requisitos da legislação civil.

$\S 1^{\mathrm{o}} \mathrm{O}$ consórcio público com personalidade jurídica de direito público integra a administração indireta de todos os entes da Federação consorciados.

$\S 2^{\mathrm{o}}$ No caso de se revestir de personalidade jurídica de direito privado, o consórcio público observará as normas de direito público no que concerne à realização de licitação, celebração de contratos, prestação de contas e admissão de pessoal, que será regido pela Consolidação das Leis do Trabalho - CLT”.

65 "Art. 1 $1^{\circ}$ Esta Lei dispõe sobre normas gerais para a União, os Estados, o Distrito Federal e os Municípios contratarem consórcios públicos para a realização de objetivos de interesse comum e dá outras providências.

$\S 1^{\circ} \mathrm{O}$ consórcio público constituirá associação pública ou pessoa jurídica de direito privado.

$\S 2^{2}$ A União somente participará de consórcios públicos em que também façam parte todos os Estados em cujos territórios estejam situados os Municípios consorciados.

$\S 3^{\circ}$ Os consórcios públicos, na área de saúde, deverão obedecer aos princípios, diretrizes e normas que regulam o Sistema Único de Saúde - SUS.

Art. $2^{\underline{0}}$ Os objetivos dos consórcios públicos serão determinados pelos entes da Federação que se consorciarem, observados os limites constitucionais".

$\S 1^{\underline{0}}$ Para o cumprimento de seus objetivos, o consórcio público poderá:

I - firmar convênios, contratos, acordos de qualquer natureza, receber auxílios, contribuições e subvenções sociais ou econômicas de outras entidades e órgãos do governo;

II - nos termos do contrato de consórcio de direito público, promover desapropriações e instituir servidões nos termos de declaração de utilidade ou necessidade pública, ou interesse social, realizada pelo Poder Público; e

III - ser contratado pela administração direta ou indireta dos entes da Federação consorciados, dispensada a licitação.

$\S 2^{0}$ Os consórcios públicos poderão emitir documentos de cobrança e exercer atividades de arrecadação de tarifas e outros preços públicos pela prestação de serviços ou pelo uso ou outorga de uso de bens públicos por eles administrados ou, mediante autorização específica, pelo ente da Federação consorciado.

$\S 3^{0}$ Os consórcios públicos poderão outorgar concessão, permissão ou autorização de obras ou serviços públicos mediante autorização prevista no contrato de consórcio público, que deverá indicar de forma específica o objeto da concessão, permissão ou autorização e as condições a que deverá atender, observada a legislação de normas gerais em vigor”. 
administração pública direta de mesmo nível de governo ou entidades da administração indireta para a concretização de objetivos de interesse comum.

Por fim, a figura do consórcio imobiliário foi criada pela Lei n. ${ }^{\circ} 10.257$, de 2001 (Lei n. ${ }^{\circ}$ 10.257/01), como uma forma de viabilizar a edificação e o aproveitamento urbano previsto no plano diretor ${ }^{66}$. Trata-se de um negócio jurídico celebrado entre o proprietário de imóvel urbano não edificado, subutilizado ou não utilizado a quem o plano diretor impõe o dever e a obrigação de utilizar o solo e o Poder Público Municipal, por meio do qual o sujeito titular do bem transfere à propriedade do bem ao Poder Público, que se encarregará de edificar e utilizar corretamente o imóvel e, posteriormente, transferirá ao proprietário a titularidade unidades imobiliárias devidamente urbanizadas ou edificadas (art. 46 da Lei n. $\left.{ }^{\circ} 10.257 / 01^{67}\right)^{68}$.

Uma vez diferenciado o consórcio para compra de bens duráveis ou para obtenção de serviço (sobre o qual, doravante, este trabalho se debruçará com exclusividade) dos demais fenômenos consorciais admitidos no ordenamento jurídico brasileiro, a correta apreensão da noção de consórcio proposta depende, antes de tudo, do entendimento do desenvolvimento e da paulatina inserção do consórcio no cotidiano das famílias brasileiras no decorrer do século XX.

\subsection{Apontamentos históricos do desenvolvimento do consórcio no Brasil}

Esta seção secundária possui por escopo pontuar os eventos considerados determinantes para a conformação do consórcio ao tratamento legal e prático verificado nos dias atuais, sem qualquer tentativa de descrição completa da história do consórcio no

66 Cf. P. A. CAVichiolli CARMOna, O Consórcio Imobiliário Como Instrumento de Intervenção Urbanística, Belo Horizonte, Fórum, 2007.

67 "Art. 46. O Poder Público municipal poderá facultar ao proprietário de área atingida pela obrigação de que trata o caput do art. 5ำ desta Lei, a requerimento deste, o estabelecimento de consórcio imobiliário como forma de viabilização financeira do aproveitamento do imóvel.

$\S 1^{\circ}$ Considera-se consórcio imobiliário a forma de viabilização de planos de urbanização ou edificação por meio da qual o proprietário transfere ao Poder Público municipal seu imóvel e, após a realização das obras, recebe, como pagamento, unidades imobiliárias devidamente urbanizadas ou edificadas.

$\S 2^{\underline{0}} \mathrm{O}$ valor das unidades imobiliárias a serem entregues ao proprietário será correspondente ao valor do imóvel antes da execução das obras, observado o disposto no $§ 2^{\mathrm{o}}$ do art. $8^{\mathrm{o}}$ desta Lei”.

68 Na prática imobiliária entre os sujeitos privados, esta operação é muito comum entre as incorporadoras e os proprietários de imóveis (chamados de terreneiros) e estrutura-se por meio da celebração de um contrato de permuta e, após a realização das obras, recebe, como pagamento, unidades imobiliárias devidamente urbanizadas ou edificadas. 
século XX, porque tal empreitada deve ser objeto da ciência histórica, com seus métodos e técnicas particulares de investigação para obtenção de conhecimento dos acontecimentos e processos do passado.

A revisão dos antecedentes históricos do consórcio, com foco no nascimento por força da iniciativa das pessoas comuns, é importante também para evidenciar a falta de criatividade contratual do titular do poder normativo, pois a disciplina das diversas categorias e tipos de contratos, no mais das vezes, não é fruto da atuação inovadora do legislador, e sim de uma atividade de compreensão, de interpretação, de valoração e de escolha das alternativas desenvolvidas pelos particulares e que desembocam na tipificação social de novos contratos e na solidificação de novas instituições no tecido social ${ }^{69}$.

\subsubsection{Possíveis antecedentes históricos do consórcio}

A primeira provável influência histórica no desenho do consórcio com as feições atuais foi o antigo clube de mercadorias, criado no seio social por volta de $1900^{70} \mathrm{e}$ fortemente regulado no governo Venceslau Brás pelo Decreto n. ${ }^{\circ} 8.598$, de 8 de março de 1911 em razão do uso de sorteios para a venda de mercadorias. O Decreto n. ${ }^{\circ}$ 8.598/1911 proibia a loteria ou rifa de qualquer natureza, incluindo a venda de mercadorias, de objetos, de bens e de direitos por meio de sorteio (art. $1 .^{\circ}$ do Decreto n. ${ }^{\circ} 8.598 / 1911^{71}$ ), mas admitia, em caráter de exceção, a "venda de artigos de commercio mediante sorteio, conhecida geralmente pela denominação de club de mercadorias" cujo prazo de duração não poderia ultrapassar a vigência das loterias federais (art. 2. ${ }^{\circ}$ do Decreto $n .^{\circ}$ 8.598/1911 ${ }^{72}$ ). O emprego da locução "conhecida geralmente pela denominação de club de

69 Cf. P. PAIS DE VASCONCELOS, Contratos Atípicos, 2. a ed., Coimbra, Almedina, 2009, p. 21: "os catálogos de modelos de contratos que o direito privado coloca à disposição das pessoas para que os utilizem nas suas relações recíprocas não são, as mais das vezes, inventados pelo legislador ex novo $e$ correspondem à recolha que é feita na lei daquilo que é característico dos contratos que com maior frequência se celebram na prática".

$70 \quad$ Cf. D. ORFAli GiaCOMINI, A Devolução cit., p. 19

71 “Art. $1^{\circ}$ Constitue jogo prohibido, sujeito ás penas civis e criminaes estatuidas, a loteria ou rifa não autorizada por lei.

Paragrapho unico. Tal se considera, entre outros jogos, a venda de objectos, mercadorias, direitos ou bens de qualquer especie por meio da sorte, qualquer que seja a fórma de sorteio."

"Art. 2 $2^{\circ}$ A venda de artigos de commercio mediante sorteio, conhecida geralmente pela denominação de club de mercadorias, sómente será permittida na vigencia do prazo das loterias autorizadas a estabelecimentos commerciaes, satisfeitas as exigencias da lei e precedendo autorização, nesta capital e no Estado do Rio de Janeiro, do ministro da Fazenda, e nos demais Estados, dos delegados fiscaes, de cuja decisão denegatoria haverá recurso voluntario para aquelle ministro.’ 
mercadorias" para qualificar a venda de artigos por meio de sorteio é de extrema importância, pois deixa evidente o surgimento do clube de mercadorias como uma manifestação da prática diária das famílias brasileiras na busca por soluções para as seguidas desvalorizações da moeda nacional durante a República Velha.

Embora muitas disposições aproximassem o clube de mercadoria das normas das loterias federais (art. 26 do Decreto n. ${ }^{\circ} 8.598 / 1911^{73}$ ), a característica diferenciadora do clube residia no fato dos participantes receberem apenas e tão somente a mercadoria objeto do clube, cujo valor jamais poderia ser convertido em pecúnia, sob pena de cassação da autorização para funcionamento do estabelecimento e a aplicação das sanções penais ao responsável pela prática de rifa ou loteria não autorizada (art. 11 do Decreto n. ${ }^{\circ}$ $\left.8.598 / 1911^{74}\right)$.

A formação do clube de mercadoria era restrita a estabelecimentos com capital integralizado em valor superior a cinquenta contos de réis (art. 3. ${ }^{\circ}$ do Decreto n. ${ }^{\circ}$ 8.598/1911 ${ }^{75}$ ) cuja autorização especial do Ministério da Fazenda era consubstanciada em uma carta patente, cabendo ao responsável pelo estabelecimento atuar como fiel depositário das quantias recebidas (art. 5. ${ }^{\circ}$ do Decreto n. ${ }^{\circ} 8.598 / 1911^{76}$ ). Toda a atuação do clube de mercado estava sujeita à rígida fiscalização do Ministério da Fazenda, por meio de fiscais nomeados em comissão pelo titular da pasta (art. 16 do Decreto n. ${ }^{\circ} 8.598 / 1911^{77}$ )

73 “Art. 26. No que forem applicaveis, vigorarão a respeito de clubs de mercadorias todas as disposições referentes á fiscalização das loterias".

“Art. 11. E' vedado, expressamente, converter-se em moeda a mercadoria do club, por parte do estabelecimento que o mantenha, seus socios ou prepostos, pena de cassar-se a autorização e reputar-se a operação loteria ou rifa não autorizada e sujeita ás respectivas comminações".

“Art. $3^{\circ} \mathrm{O}$ pedido da autorização será feito em requerimento acompanhado de certidão da Junta Commercial competente, mostrando ser o capital realizado do estabelecimento superior a cincoenta contos de réis, e de documento que prove achar-se o mesmo quite para com a Fazenda Publica - Federal, Estadoal e Municipal."

76 "Art. $5^{\circ}$ A autorização constará de uma carta patente, que não será expedida sem que se recolha á repartição fiscal do logar a quota semestral adeantada de um conto de réis, prescripta pelo art. 36 da lei n. 2.321, de 30 de dezembro de 1910, e seja assignado o termo de fiel depositario das quantias que o estabelecimento receber para serem applicadas ao fim determinado nos planos e pactuado pelas partes, com expressa declaração por parte do pretendente de sujeitar-se ás multas e demais disposições do presente regulamento.

Paragrapho unico. Esse termo será assignado perante a Procuradoria Geral da Fazenda Publica, quanto aos clubs organizados no Districto Federal e no Estado do Rio de Janeiro, e nas respectivas Delegacias Fiscaes quanto aos que o foram nos Estados. Quando organizados os clubs no interior dos Estados, o termo poderá ser lavrado e assignado, em documento avulso, perante o fiscal ou funccionario federal designado, que o remetterá, para ser registrado e archivado, á repartição que competir outorgar autorização para funccionar.”

77 “Art. 16. A fiscalização dos clubs será exercida por fiscaes, cujo numero fixará, tendo em vista os clubs existentes, o ministro da Fazenda, que será as nomeações precisas em commissão.

$\S 1^{\circ}$ Nos Estados haverá um ou mais fiscaes, que exercerão a fiscalização dos clubs nas circumscripções que forem estabelecidas para facilidade desse serviço.

$\S 2^{\circ}$ Fóra da séde dos fiscaes exercerá as attribuições respectivas, que não devam ser adiadas a bem dos interessados, o funccionario federal que fôr designado pelo ministro da Fazenda." 
com competência para programar o calendário de sorteios (art. $7 .^{\circ}$ do Decreto n. ${ }^{\circ}$ $8.598 / 1911^{78}$ ) e comparecer na realização de cada sorteio (art. 10, primeira parte, do Decreto n. ${ }^{\circ} 8.598 / 1911^{79}$ ).

Uma vez concluídas as providências preliminares, os clubes de mercadoria deveriam realizar sorteios nas datas pré-fixadas, independente do número de associados e das entradas pagas (art. 10, in fine, do Decreto n. ${ }^{\circ}$ 8.598/1911 ${ }^{80}$ ). Para garantir a saúde financeira do clube, decairiam os direitos do associado inadimplente de três prestações sucessivas, podendo o estabelecimento responsável pela criação e administração do clube tomar para si os valores até então contribuídos pelo associado excluído (art. 9. ${ }^{\circ}$ do Decreto n. $\left.{ }^{\circ} 8.598 / 1911^{81}\right)$.

Como parte do sistema de fiscalização, o Decreto n. ${ }^{\circ}$ 8.598/1911 impunha ao estabelecimento administrador do clube uma detalhada escrituração em livro específico, autenticado pelo fiscal em todas as folhas e conservado com as formalidades dos livros comerciais (art. 12 do Decreto n. ${ }^{\circ} 8.598 / 1911^{82}$ ), no qual deviam ser registrados, dentre outras informações, os planos do clube, o número de cada participante, a identificação do bem a ser comprado e o preço de referência (art. 13do Decreto n. ${ }^{\circ} 8.598 / 1911^{83}$ ).

A efetividade das normas sobre clube de mercadoria foi pensada por meio da fixação de sanções, especialmente multas pecuniárias variando de $200 \S$ a $500 \$$ para o

78 "Art. $7^{\mathbf{0}}$ Os estabelecimentos não farão funccionar clubs antes de concedida a autorização, assignando-lhes fiscal, de accôrdo com os proprietarios e as conveniencias do serviço, os dias do sorteio, que serão annunciados pela imprensa, onde houver."

79 "Art. 10. Os clubs terão sorteios proprios extrahidos com a presença do fiscal ou se servirão dos sorteios das loterias autorizadas; em um ou outro caso o resultado do sorteio será affixado em lista na séde do estabelecimento e publicado pela imprensa, onde houver, com a assignatura do fiscal e do depositario como representante do estabelecimento ou seu proprietario".

80 "Art. 10. Os clubs terão sorteios proprios extrahidos com a presença do fiscal ou se servirão dos sorteios das loterias autorizadas; em um ou outro caso o resultado do sorteio será affixado em lista na séde do estabelecimento e publicado pela imprensa, onde houver, com a assignatura do fiscal e do depositario como representante do estabelecimento ou seu proprietario".

${ }_{81}$ "Art. 9. ${ }^{\circ}$ Os direitos dos prestamistas faltosos em tres prestações successivas poderão ser declarados pelo estabelecimento caducos em seu beneficio".

“Art. 12. Os clubs terão seu livro de inscripção aberto, encerrado e rubricado pelo fiscal ou por quem fôr devidamente designado, em todas as suas folhas, e escripturado na fórma dos livros commerciaes".

"Art. 13. Esse livro mencionara:

$1^{\circ}$, os planos do club e o estabelecimento a que pertença;

$2^{\circ}$, o nome e naturalidade de seus proprietarios e do depositario de que trata este regulamento;

$3^{\circ}$, o numero de ordem ou lettra do club e o das inscripções em ordem arithmetica;

$4^{\text {o }}$, o nome, domicilio e profissão do prestamista em seguida ao numero escolhido;

$5^{\circ}$, a importancia de cada prestação;

$6^{\circ}$, a especificação minuciosa do objecto do club, dando-se o quilate dos metaes e pedras preciosas, a marca da fabrica, sua denominação no commercio, etc.;

$7^{\circ}$, o preço por extenso da cousa a vender e o processo, dia, hora e logar do sorteio;

$8^{\circ}$, finalmente todas as condições ou vantagens em que as partes convenham". 
descumprimento das regras formais e de 500\$ a 2:000\$ para o inadimplemento da obrigação de entregar a mercadoria ao participante sorteado (art. 20 do Decreto n. ${ }^{\circ}$ $8.598 / 1911^{84}$ ). Como forma de estimular a fiscalização sobre os clubes de mercadoria, o Decreto n. ${ }^{\circ}$ 8.598/11 adotou um mecanismo interessante, mas que poderia gerar incentivos perversos, atribuindo ao fiscal e ao denunciante da violação metade da multa pecuniária efetivamente arrecadada por violação das normas sobre clubes de mercadoria (art. 23 do Decreto n. ${ }^{\circ} 8.598 / 1911^{85}$ ).

Apesar de não ser identificado estudo específico ${ }^{86}$, na análise dos antecedentes históricos do consórcio é necessário considerar a possível influência do milenar mecanismo japonês denominado Mujin ou Tanomoshi-Ko ${ }^{87}$, baseado na solidariedade e na ajuda mútua e amplamente utilizado pelos imigrantes japoneses ao redor do mundo, dentre as diversas manifestações culturais oriundas do Japão incorporadas no modo de ser brasileiro, no surgimento do sistema de $\operatorname{consórcios~}^{88}$. A chegada do navio Kasato Maru ao cais 14 do porto de Santos em 17 de junho de 1908, como resultado do acordo entre o Estado de São Paulo e a Companhia Imperial de Imigração Tókio-Japão, foi o marco inicial da imigração japonesa no Brasil, um processo longo e de impactos profundos na formação da cultura brasileira, especialmente nos Estados de São Paulo e do Paraná, onde traços da cultura japonesa foram misturados e fundidos com costumes locais ${ }^{89}$.

84 “Art. 20. Incorrerão na multa fiscal de $200 \S$ a $500 \$$ os clubs de mercadorias omissos ou demorados em cada publicação que devam fazer, ou que infrinjam alguma disposição legal a que não esteja imposta pena especial, e na multa de 500\$ a 2:000\$ os que não effectuarem a entrega do objecto do sorteio á vista da respectiva cautela".

${ }_{85}$ "Art. 23. Metade das multas, julgadas procedentes e effectivamente arrecadadas, será adjudicada ao fiscal e dividida em partes iguaes entre elle e os denunciantes da infracção, si o existirem.”.

86 De acordo com a ASSOCIAÇÃO BRASILEIRA DAS ADMINISTRADORAS DE CONSÓRCIO, os imigrantes japoneses efetivamente estabeleceram os Tanomoshi-Ko em meados de 1950 (Cf. Consórcio - A realidade de um Sonho Brasileiro, São Paulo, ABAC, 2005, p. 5).

87 Na tradição budista, Mujin significa "inesgotável" e Tanomoshi-ko pode ser traduzido como "comunidade confiável" ou "comunidade da confiança" (Cf. R. DEKLE - K. HAMADA, On the Development of Rotating Credit Associations in Japan, Economic Development and Cultural Change, vol. 49, n. 1, 2000, pp. 77-90).

88 Considerando que os imigrantes japoneses fixados nos EUA durante o século XX reproduziram em solo estadunidense o Tanomoshi-Ko como forma de acessarem o crédito que lhes era negado pelas instituições financeiras tradicionais (cf. D. J. O’BRIEN - S. S. FUGITA, The Japanese American Experience, Bloomington, Indiana University Press, 1991, p. 27), é possível a adoção do modelo do Ko pelos imigrantes japoneses no Brasil em suas comunidades. Também é possível, dada a evidente incorporação de traços culturais e sociais japoneses na formação da identidade brasileira, a penetração do modelo do Ko conforme o processo de abertura das comunidades japonesas e o consequente diálogo com a sociedade brasileira progredia ao longo dos anos.

Para uma descrição detalha da imigração japonesa no Brasil, ver Almanaque do Centenário da Imigração Japonesa no Brasil, São Paulo, Escala, 2008; F. MoRAIS, Corações Sujos - A história da Shindo Renmei, São Paulo, Companhia das Letras, 2000 e C. SAKURAI, Os Japoneses, São Paulo, Contexto, 2007. 
Em termos simples, consiste o Tanomoshi-Ko em modelo de poupança rotativa e de associação de crédito originário das práticas budistas em templos na Índia, na China e na Coréia e cujo primeiro registro histórico na sociedade japonesa data de 1255 EC, assumindo importante papel no cotidiano das famílias do Japão no período Muromachi entre 1338 EC e 1467 EC $^{90}$. Conforme explicam R. DEKLE e K. HAMADA ${ }^{91}$, o TanomoshiKo tradicional possuía as seguintes regras estruturantes básicas: (1) os iniciadores ou os fundadores de Ko eram chamados de pais; (2) os pais reuniam uns poucos ou mais de dez pessoas que comporiam os membros do $\mathrm{Ko}$; (3) os membros do Ko precisavam consentir expressamente com a operação; (4) os membros do Ko participavam de reuniões periódicas nas quais deveriam contribuir certa soma de dinheiro; (5) o dinheiro arrecadado formava um "pote" pago para pessoa determinada por sorteio ou por lance em um leilão; (6) no caso da contemplação por sorteio, o participante contemplado não poderia participar dos sorteios remanescentes; (7) o Ko era dissolvido automaticamente assim que todos os participantes fossem contemplados, seja por sorteio ou por lance; e (8) poderia haver a fixação de juros pagos pelos primeiros contemplados em favor dos últimos, por meio da atribuição de um "pote" maior do que a soma total das contribuições dos últimos contemplados.

Uma característica importante do Tanomoshi-Ko era a ausência de vinculação para a aplicação dos recursos recebidos pelo contemplado, que poderia utilizar o pote para reformar a casa, comprar uma fazenda, ou investir num pequeno negócio. Por esse motivo, o Ko era muito utilizado para fins de beneficência e de caridade, estruturado para tanto de maneira que as pessoas afligidas por certa calamidade fossem as primeiras contempladas, recebendo os recursos necessários para lidar com as dificuldades enfrentadas. Embora tal modalidade de $K o$ fosse construída com fins de caridade, todos os beneficiados eram membros participantes do Tanomoshi-Ko e realizavam em cada reunião do Ko a mesma contribuição exigida pelos demais participantes; um mecanismo engenhoso para permitir aos beneficiados conservar sua honra e sua dignidade por devolver aos demais os recursos recebidos do $K o$.

90 Cf. R. DeKLE - K. HAMADA, On the Development cit., pp. 77-90. O papel do Ko na evolução da sociedade japonesa ilustra bem a importância da História não apenas como educadora por meio das experiências do passado, mas também como diagnosticadora do presente e do futuro, profundamente conectados com o passado pelo liame da persistência das instituições, pois as escolhas de hoje e amanhã são moldadas pelo passado, e a correta compreensão do passado depende da narrativa da evolução das instituições (cf. D. C. NORTH, Institutions, Institutional Change and Economic Performance, 27. ${ }^{\mathrm{a}}$ ed., New York, Cambridge University Press, 2009, p. vii)

91 On the Development cit., pp. 77-90. 
Como o Ko podia prever o pagamento de juros pelos primeiros contemplados em favor dos últimos sorteados ${ }^{92}$, rapidamente assumiu o papel fulcral na intermediação entre os titulares de recursos superavitários e as pessoas deficitárias de recursos, passando a ser a coluna de sustentação do sistema financeiro japonês por muitos séculos. De fato, até a criação de um sistema bancário de modelo ocidental ocorrida no âmbito da Reforma Meiji, o Tanomoshi-Ko foi uma das poucas instituições ${ }^{93}$ sociais permanentes e desempenhou com elevada eficiência o papel dos bancos europeus na circulação de riqueza por meio da atividade financeira ${ }^{94}$.

Embora não seja possível precisar a verdadeira influência do clube de mercadorias e do Ko no desenvolvimento do sistema de consórcios no Brasil, o princípio fundamental ${ }^{95}$ de realização de contribuições periódicas para a formação de um fundo comum a ser atribuído por sorteio a cada participante ao longo do tempo de duração do grupo residia e pautava a constituição dessas iniciativas de captação e distribuição de recursos ${ }^{96}$.

\subsubsection{A evolução da disciplina do consórcio no Brasil}

Como a gênese do consórcio encontra-se no tecido social, no espírito criador do ser humano, concretizado no exercício do poder de autorregramento de interesses (mais conhecido pelo nome de autonomia privada) decorrente do reconhecimento pelo ordenamento jurídico da pessoa humana como um fim em si mesmo, dotada da capacidade de fazer escolhas definidoras do seu próprio valor ${ }^{97}$, que em face da falta de crédito específico para o consumidor em um ambiente de elevadas taxas de juros e inflação

92 Apesar de facultativo, a aplicação de juros era vista como uma necessidade de justiça equitativa, pois do contrário os últimos contemplados acabariam por financiar economicamente os primeiros, sem receber nenhuma compensação financeira para tanto.

93 A palavra instituição no texto é empregada com o sentido de conjunto de normas, jurídicas, sociais, morais e econômicas, disciplinadoras da interação entre as pessoas, restringindo, conformando e o construindo as trocas sociais, econômicas, políticas ou culturais inerentes aos relacionamentos humanos (Cf. D. C. NoRTH, Institutions, Institutional Change and Economic Performance, 27. a ed., New York, Cambridge University Press, 2009, pp. 3 e ss.).

$94 \quad$ Cf. Cf. R. DEKLE - K. HAMADA, On the Development cit., p. 77-90.

95 Cf. A. M. Sousa Figueiredo, $A B C$ do Consórcio cit., p. 25.

96 D. ORFALI GIACOMINI sugere que o consórcio encontrou inspiração no consortium romano e nas várias experiências realizadas desde a Idade Média para a captação e distribuição de recursos ( $A$ Devolução cit., p. 20). Entretanto, conforme exposto no texto, carecem estudos históricos profundos para embasar uma conclusão tão definitiva sobre o papel dessas iniciativas na formação do consórcio contemporâneo.

97 Cf. W. FlÜME, Allgemeiner Teil des Bürgerlichen Rechts, vol. II, Das Rechtsgeschäft, 4. ${ }^{\text {a }}$ ed., Berlin - Heidelberg - New York - London - Paris - Tokyo - Hong Kong - Barcelona - Budapest, Springer, 1992, pp. 1-22. 
significativa, desenvolveram mecanismos próprios de adaptação às circunstâncias, é difícil precisar o momento exato da constituição do primeiro consórcio contemporâneo. A hipótese mais aceita data o consórcio de $1962^{98}$, fruto da iniciativa de duzentos funcionários do Banco do Brasil, ávidos por comprar os automóveis lançados por uma indústria automotiva nascente, em um ambiente de insegurança institucional e de falta generalizada de crédito, unidos pelo compromisso de contribuição ao longo de sessenta meses de valor suficiente para que cada membro do grupo comprasse o automóvel, com atribuição do montante total formado a cada mês por sorteio entre os vários participantes, em reuniões festivas na nas dependências da Associação Atlética do Banco do Brasil (AABB). O sucesso do modelo, pautado na ausência de juros, pouca burocracia na apresentação de garantias, na confiança entre os participantes e a confraternização, inspirou várias iniciativas semelhantes no âmbito das diversas AABBs espalhadas pelo Brasil $^{99}$. Em pouco tempo, o consórcio deixou os limites da AABB e ganhou aceitação popular como catalisador de crédito e impulsionador do consumo, crescendo de maneira desordenada e assumindo o papel principal na compra de veículos automotores durante a década de 1960, como bem ilustra o caso dos cerca de cinquenta e cinco mil consorciados desejosos de comprar um automóvel da montadora Willys Overland do Brasil em 1967.

O rápido florescimento do consórcio levou ao surgimento das primeiras administradoras de consórcio organizadas na forma de sociedades e de associações com objeto social específico de administração dos recursos dos consorciados para aquisição de veículos automotores. Ao mesmo tempo, a falta de disciplina positiva e o crescimento desordenado permitiram a muitos aventureiros atuarem como administradores de consórcios, resultando em negligência na gestão dos recursos e casos de fraude nos quais os administradores simplesmente desapareciam após coletar os recursos dos consorciados, o que gerou prejuízos consideráveis para os consumidores e trouxe um grande descrédito para o modelo de consórcios ${ }^{100}$.

Em 21 de setembro de 1967, com a finalidade de "resguardar os interesses do público participante de consórcios (fundos mútuos ou outras formas associativas

98 Cf. ASSOCIAÇÃo BRASILEIRA DAS ADMINISTRADORAS DE CONSÓRCIO, Consórcio - A realidade cit., p. 5 e ss; A. M. Sousa FigueIREDO, ABC do Consórcio cit., p. 25; D. Orfali GIacomini, A Devolução cit., p. 20; F. Lopes FerreIRA, Consórcio e Direito - Teoria e Prática, Belo Horizonte, Del Rey, 1998, p. 21-22; F. FERnANDES RIBEIRo MAIA, O Sistema de Consórcio Financeiro na Lei 11.795/2008, Revista de Direito Bancário e do Mercado de Capitais, vol. 47, Jan, 2010, p. 66.

99 Cf. A. M. Sousa FigueIREDO, ABC do Consórcio cit., p. 25; F. LOPES FerReIRA, Consórcio e Direito cit., p. 21-22.

$100 \quad$ Cf. A. M. Sousa FigueIREDO, ABC do Consórcio cit., p. 26. 
assemelhadas) que objetivem a coleta de poupanças para propiciar a venda ou o autofinanciamento da aquisição de bens móveis de qualquer natureza”, o Banco Central, por meio da Resolução n. ${ }^{\circ} 67$ (Resolução n. ${ }^{\circ}$ 67/67), trouxe a primeira disciplina jurídica do consórcio enquanto instituição social. Chama a atenção na Resolução n. ${ }^{\circ}$ 67/67, face à necessidade prática de normatizar o consórcio, a adoção pelo Banco Central de uma estratégia regulatória indireta, impondo uma série de requisitos para a abertura, pelos bancos comerciais e pelas caixas econômicas, de contas de depósito para os recursos

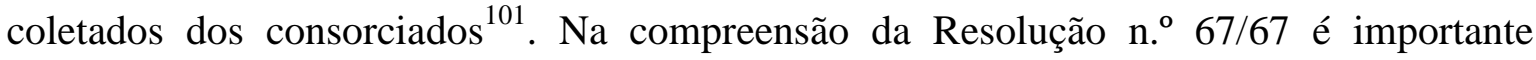
identificar os limites do desempenho da função normativa pelo Banco Central ${ }^{102}$, pois os destinatários das normas jurídicas eram apenas os participantes do sistema financeiro, o que excluía tanto os consorciados como os administradores de consórcios. Assim, a estratégia do Banco Central foi influenciar a conduta das pessoas (consorciados e administradores) por meios indiretos, proibindo que as instituições financeiras aceitassem o depósito de recursos coletados de consórcios que não preenchessem os requisitos mínimos de viabilidade e higidez ${ }^{103}$.

No final da década de 1960, o ambiente macroeconômico brasileiro e descrédito sobre o consórcio fez com que os participantes do setor, preocupados com a sobrevivência do sistema, fundassem a Associação Brasileira das Administradoras de Consórcio e o Sindicato Nacional das Administradoras de Consórcio, com o objetivo de aperfeiçoar

101 O Banco Central "recomendou" aos bancos comerciais e às caixas econômicas somente abrirem contas de depósito vinculadas a consórcios após a análise da idoneidade moral e da capacidade financeira dos administradores e da existência de cláusulas no contrato de consórcio aptas a salvaguardar a viabilidade econômico-financeira do grupo, estruturar a apresentação de garantias suficientes pelos contemplados para assegurar o pagamento das entradas remanescentes após adquirirem o bem e a obrigação dos administradores depositarem os recursos coletados em banco comercial ou caixa econômica, admitindo-se o levantamento dos recursos apenas para a aplicação na aquisição dos bens objeto do consórcio. Adicionalmente, a Resolução n. ${ }^{\circ}$ 67/1967 também proibiu a abertura de contas de depósito vinculadas a novos planos de consórcio sem a apresentação de instrumento de regulamento, contendo, além das salvaguardas acima mencionadas, a vedação ao recebimento de moeda do valor do bem, regras para devolução dos valores em caso de desistência, representação dos consorciados junto à administradora, proibição de operações financeiras com os recursos coletados, valor mínimo de cinco vezes o maior salário mínimo para o bem objeto do consórcio, prazo máximo de duração do plano de cinquenta meses e a contribuição mensal mínima de dois por cento do valor do bem.

102 Para uma análise sumária da função normativa na administração pública, vide E. GRAU, O Direito Posto e o Direito Pressuposto, São Paulo, Malheiros, 1996, p. 179-182.

103 A Resolução n. ${ }^{\circ}$ 67/1967 expressamente excluiu do seu âmbito de aplicação os consórcios para aquisição de bens imóveis, pois o Banco Central entendia que tal modalidade configurava uma sociedade de crédito imobiliário cuja constituição dependia de aprovação do Banco Nacional de Habitação, nos termos do art. 8. ${ }^{\circ}$, inciso IV da Lei n. ${ }^{\circ} 4.380$, de 21 de agosto de 1964. 
normas e mecanismos para garantir o funcionamento do sistema e conquistar a confiança dos consumidores ${ }^{104}$.

Instituído socialmente, regrado indiretamente pelo Banco Central por meio das normas regulamentares dirigidas aos bancos comercias e caixas econômicas que recebiam os recursos coletados, o consórcio para aquisição de bens recebeu a primeira disciplina legal na Lei n. ${ }^{\circ}$ 5.768, de 20 de dezembro de 1971 (Lei n. ${ }^{\circ}$ 5.768/71), que em seus artigos 7..$^{\circ}$ e $8 .^{\circ}$ sujeitou a realização das "operações conhecidas como consórcio" à prévia aprovação do Ministério da Fazenda, por meio da Secretaria da Receita Federal, a qual somente seria conferida aos empresários com comprovada capacidade técnica, econômica e financeira cujo plano de consórcio fosse dotado de viabilidade nas formas de captação, de gestão e de aplicação dos recursos. A Lei n. ${ }^{\circ}$ 5.768/71 foi regulamentada pelo Decreto n. ${ }^{\text { } 70.951, ~ d e ~} 9$ de agosto de 1972 (Decreto n. $\left.{ }^{\text {o }} 70951 / 72\right)^{105}$, o primeiro regulamento específico do consórcio no Brasil, cujas inovações foram sensíveis para o posterior desenvolvimento do sistema nos moldes atuais: (1) requisitos rígidos para a constituição e administração de grupos de consórcio; (2) taxa de administração de no máximo doze por cento sobre o valor do bem; (3) taxa de adesão de um por cento cobrada na adesão ao plano e descontada na taxa de administração; (4) cláusulas mínimas a serem incluídas no contrato de participação em consórcio celebrado por adesão; e (5) possibilidade de constituição do consórcio para aquisição de bens móveis e imóveis ${ }^{106}$.

A disciplina do consórcio, embora ainda incompleta, foi suficiente para levar à eliminação das administradoras de consórcio aventureiras e fraudulentas, conferindo a estabilidade necessária para a consolidação definitiva do sistema ${ }^{107}$ e o desenvolvimento de estruturas para a aquisição de um sem número bens de consumo e serviços. Desse modo, em meados da década de 1970, pouco tempo após o advento da Lei n. ${ }^{\circ}$ 5.768/71 e do

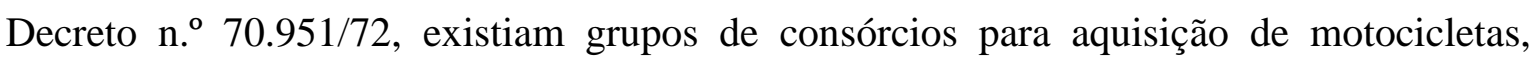
caminhões, embarcações, implementos agrícolas, aeronaves e antenas parabólicas.

Durante a década de 1980, o sistema de consórcios passou a viabilizar a aquisição de eletrodomésticos e eletroeletrônicos e desempenhou importante papel na luta contra a

\footnotetext{
104 Cf. A. M. Sousa FigueIREDO, ABC do Consórcio, cit., p. 25-26.

105 O objeto da Lei n. ${ }^{\circ} 5.768 / 1971$ e do Decreto n. $^{\circ} 70.951 / 1972$ era disciplinar distribuição gratuita de prêmios, mediante sorteio, vale-brinde ou concurso, e a proteção à poupança popular, o que acabava por incluir, dentre as diversas modalidades de sorteio e captação de poupança popular, o consórcio.

106 O consórcio para aquisição de bens imóveis ganhava, assim, sua autonomia, não sendo mais encarado pelo ordenamento jurídico como uma sociedade de crédito imobiliário, mas como uma operação econômica específica e que granjeava um tratamento próprio.

107 Cf. F. LOPES FERREIRA, Consórcio e Direito cit., p. 26.
} 
inflação por permitir equilibrar e programar a demanda e o consumo ao longo do tempo, medida fundamental para a efetividade das diversas intervenções estatais na economia e os vários planos econômicos ${ }^{108}$. Apesar de ajudar a reduzir a pressão inflacionária decorrente do excesso de demanda, o consórcio, principalmente no segmento de automóveis, enfrentou dificuldades com a escassez de $\operatorname{produtos}^{109}$, o aumento excessivo das entradas dos consorciados, o reajuste do saldo do caixa, a dilatação dos grupos de consórcio e o despreparo das administradoras de consórcios para lidar com a nova realidade, culminando numa enxurrada de demandas judiciais questionando o funcionamento do sistema ${ }^{110}$.

Novamente, o Estado não poderia fechar os olhos para a situação dos consórcios e as entidades da Administração Pública Direta e Indireta, tais como o Ministério da Economia, Fazenda e Planejamento, o Ministério da Fazenda, a Secretaria da Receita Federal, a Superintendência de Seguros Privados (SUSEP), o Conselho Monetário Nacional e o Banco Central, produziram uma hipertrofia de normas jurídicas impondo medidas paliativas com o objetivo de solucionar os problemas práticos do sistema de consórcio, mas insuficientes para atender aos anseios dos consorciados e das administradoras de consórcios ${ }^{111}$. A hiperprodução normativa no período atingiu estágio tão avassalador que levou o Ministério da Fazenda a organizar, sistematizar e consolidar as normas sobre consórcios elaboradas nas mais diferentes esferas do Poder Público por meio da Portaria MF n. ${ }^{\circ}$ 330, de 23 de setembro de 1987 (Portaria MF n. ${ }^{\circ}$ 330/87).

A relevância do consórcio no mercado de consumo brasileiro no período e sua potencialidade para reduzir os efeitos da pressão inflacionária pela programação da demanda - bem ilustrada pelas diversas tentativas governamentais para manter o funcionamento regular do sistema de consórcios - foi compreendida pelo Poder Constituinte, que conferiu à União o poder privativo de produzir normas legais para disciplinar o sistema de consórcios (Constituição Federal, art. 22, inciso $\mathrm{XX}^{112}$ ).

\footnotetext{
108 Cf. D. Orfale Giacomini, A Devolução cit., p. 22.

109 Nesta época, os consorciados contemplados eram titulares de crédito contra o grupo de consórcio à entrega e à transferência da propriedade do bem objeto do consórcio, o que exigia da administradora uma atuação diligente na aquisição do bem e repasse para o consorciado. Como se verá, a solução atual é baseada na atribuição de crédito à entrega dos recursos financeiros diretamente do grupo de consórcio para o vendedor do bem ou para o prestador do serviço objeto do consórcio escolhido pelo próprio consorciado.

110 Cf. A. M. Sousa Figueiredo, $A B C$ do Consórcio cit., p. 26-28; D. Orfale Giacomini, $A$ Devolução cit., p. 22; ASSOCIAÇÃO BRASILEIRA DAS ADMINISTRADORAS DE CONSÓRCIOS, O Consórcio $-a$ Realidade cit., p. 16.

111 Para uma descrição detalhada dos diplomas normativos no período, vide ASSOCIAÇÃo BRASILEIRA DAS ADMINISTRADORAS DE CONSÓRCIOS, O Consórcio - a Realidade cit., p. 16 e ss.

112 "Art. 22. Compete privativamente à União legislar sobre:

[...]
} 
No ano seguinte à promulgação da Constituição Federal de 1988, o Ministério da Fazenda, na mesma tônica de consolidação das normas sobre consórcios iniciada em 1987, editou a Portaria n. ${ }^{o} 190$, de 27 de outubro de 1989 (Portaria MF n. ${ }^{\circ}$ 190/89), cujo objeto foi estruturar didaticamente o sistema de consórcios, trazendo, pela primeira vez no ordenamento jurídico brasileiro, um conceito jurídico de consórcio claro e palatável não apenas para fins operacionais dos juristas, mas também para os consumidores e para as administradoras de consórcio. Apesar dos avanços trazidos pela Portaria MF n. ${ }^{\circ}$ 190/89, a instabilidade econômica assolava o país no início da última década do século XX, exigindo novas e firmes intervenções governamentais no setor de consórcios, desaguando na proibição por tempo indeterminado da realização de qualquer operação com consórcios, a formação de novos grupos e a comercialização de cotas de grupos de consórcios, conforme a Resolução do Banco Central e do Conselho Monetário Nacional n. ${ }^{\circ}$ 1.778, de 19 de dezembro de 1990 (Resolução Bacen/CMN n. ${ }^{\circ}$ 1.778/90).

O poder de produção de normas legais conferido à União pela Constituição foi exercido no âmbito das medidas de desindexação da economia brasileira contidas na Lei n. ${ }^{\circ} 8.177$, de $1^{\circ}$ de março de 1991 (Lei n. ${ }^{\circ} 8.177 / 91$ ), a partir da transferência para o Banco Central do Brasil dos poderes anteriormente atribuídos ao Ministério da Fazenda à Secretaria da Receita Federal para autorizar o funcionamento das administradoras de consórcios e a comercialização das cotas, regulamentar os consórcios de maneira a construir um verdadeiro sistema de consórcios e fiscalizar o funcionamento desse sistema (art. 33 da Lei n. ${ }^{\circ} 8.177 / 91^{113}$ ). Em 1992, o Banco Central deu início à reorganização e à reconstrução do sistema de consórcios com a edição da Resolução n. ${ }^{\circ}$ 1.936, de 30 de junho de 1992 (Resolução n. ${ }^{\circ}$ 1.936/92), que ab-rogou a Resolução Bacen/CMN n. ${ }^{\circ}$ 1.778/90 e permitiu a realização de novas operações de consórcio. No mesmo dia 30 de junho de 1992, o Banco Central editou a Circular n. ${ }^{o} 2.196$ (Circular n. ${ }^{\circ}$ 2.196/92), contendo um regulamento detalhado para a constituição e o funcionamento de grupos de consórcio referenciados em automóveis, em camionetas, em buggies e em utilitários de produção nacional ou estrangeira, incluindo os limites para constituição dos grupos, os prazos de duração, número máximo de participantes, o valor das taxas de administração e demais cláusulas padronizadas a serem incluídas nos contratos. Poucos meses depois, a

\footnotetext{
XX - sistemas de consórcios e sorteios".

113 "Art. 33. A partir de $1^{\circ}$ de maio de 1991, são transferidas ao Banco Central do Brasil as atribuições previstas nos arts. $7^{\circ}$ e $8^{\circ}$ da Lei $\mathrm{n}^{\circ} 5.768$, de 20 de dezembro de 1971 , no que se refere às operações conhecidas como consórcio, fundo mútuo e outras formas associativas assemelhadas, que objetivem a aquisição de bens de qualquer natureza".
} 
Circular n. ${ }^{\circ}$ 2.230, de 23 de setembro de 1992 (Circular n. ${ }^{\circ}$ 2.230/92) determinou a aplicação do regulamento aprovado pela Circular n. $.^{\circ} 2.196 / 92$ à constituição e ao funcionamento de grupos de consórcio para a aquisição de motocicletas e motonetas. No final do ano, a Circular n. ${ }^{\circ} 2.255$, de 9 de dezembro de 1992 (Circular n. ${ }^{\circ}$ 2.255/92), alterou sensivelmente o regulamento do consórcio, transformou os consórcios referenciados em bugies em consórcios de automóveis e permitiu a aplicação das novas normas aos grupos de consórcio então constituídos, condicionada à aprovação dos consorciados em assembleia geral. Em 1993, a Circular n. ${ }^{\circ} 2.312$, de 26 de maio (Circular

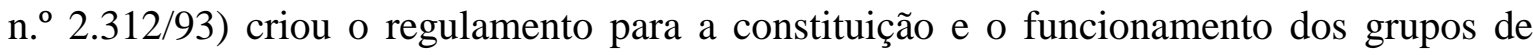
consórcio para aquisição de passagens aéreas. Não muito tempo depois, o Banco Central, por meio da Circular n. ${ }^{\circ} 2.342$, de 14 de julho 1993 (Circular n. ${ }^{\circ}$ 2.342/93), ampliou a incidência das normas do regulamento anexo à Circular n. ${ }^{\circ} 2.196 / 92$ para os grupos de consórcio referenciados em caminhões, em ônibus, em tratores, em equipamentos rodoviários, em máquinas e equipamentos agrícolas, em aeronaves e em embarcações. Nessa linha de normatização dos diversos segmentos, a Circular n. ${ }^{\circ} 2.386$, de 2 de dezembro de 1993 (Circular n. ${ }^{\circ}$ 2.386/93), criou um regulamento específico para a constituição e o funcionamento dos grupos de consórcios para a aquisição de eletrodomésticos, de eletroeletrônicos, de móveis, de brinquedos, de instrumentos musicais, de bicicletas, dentre outros. Por fim, a Circular n. ${ }^{\circ} 2.394$, de 21 de dezembro de 1993 (Circular n. ${ }^{\circ}$ 2.394/93), alterou o regulamento de consórcios anexo à Circular n. ${ }^{\circ}$ $2.196 / 92^{114}$.

Uma nova etapa na disciplina do consórcio, caracterizada pela redução do desempenho da função normativa pelo Banco Central e incremento na atividade de fiscalização ${ }^{115}$, começou com o advento de um novo regulamento do sistema de consórcios

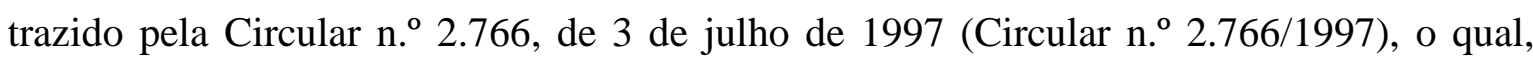
além de conceituar o consórcio como "reunião de pessoas físicas elou jurídicas, em grupo fechado, promovida pela administradora, com a finalidade de propiciar a seus integrantes a aquisição de bem, conjunto de bens ou serviço turístico por meio de autofinanciamento", diminuiu as exigências formais sobre os contratos de participação em grupo de consórcio, permitindo às administradoras fixarem livremente os limites para constituição dos grupos,

114 Cf. A. M. Sousa Figueiredo, $A B C$ do Consórcio cit., p. 26-32; D. Orfale GiaComini, $A$ Devolução cit., p. 22 e ss.; ASSOCIAÇÃo BRASILEIRA DAS ADMINISTRADORAS DE CONSÓRCIOS, O Consórcio - a Realidade cit., p. 16 e ss.

115 Cf. F. LOPES FerReIRA, Consórcio e Direito cit., p. 170; A. M. Sousa FIGUEIREDO, ABC do Consórcio cit., p. 33. 
os prazos de duração, a cobrança das taxas e despesas, os números de participantes, as formas de contemplação e as entradas mensais dos participantes ${ }^{116}$. Como contrapartida da maior amplitude de poder de autorregramento para a constituição e conformação de consórcios, a Circular n. ${ }^{\circ}$ 2.766/1997 estabeleceu um regime de envio periódico de informações ao Banco Central pelas administradoras de consórcios, incluindo a quantidade de grupos em andamento, número de cotas "vendidas", contempladas e substituídas, número de participantes ativos, índice de inadimplemento, taxa média de administração e bens pendentes de entrega.

Embora a Circular n. ${ }^{\circ}$ 2.766/1997 tenha desenhado um regulamento único para todas as categorias de consórcio, do ponto de vista operacional, financeiro e logístico, os riscos envolvidos na administração de um grupo de consórcio para a aquisição de uma aeronave são diferentes (para não dizer maiores) do que os riscos decorrentes da administração de um grupo referenciado em uma motocicleta. Riscos diversos também exigem uma atividade fiscalizadora especificamente adequada para lidar com as particularidades associadas a cada tipo de risco. Assim, logrando facilitar a tarefa fiscalizadora, as informações periódicas prestadas pelas administradoras de consórcios sob a égide da Circular n. ${ }^{\circ}$ 2.766/1997 deveriam ser divididas em seis segmentos, conforme previsto no art. 2. ${ }^{\circ}$ da Circular n. ${ }^{\circ} 2.889$, de 20 de maio de 1999 (Circular n. ${ }^{\circ}$ 2.889/1999): (1) imóveis; (2) tratores, equipamentos rodoviários, máquinas e equipamentos agrícolas, embarcações, aeronaves, veículos automotores destinados ao transporte de carga com capacidade superior a $1.500 \mathrm{~kg}$ e veículos automotores destinados ao transporte coletivo com capacidade para vinte passageiros ou mais; (3) veículos automotores não incluídos no segmento 2, exceto motocicletas e motonetas; (4) motocicletas e motonetas; (5) outros bens móveis duráveis; e (6) serviços turísticos.

Passados onze anos, o sistema de consórcios foi novamente reestruturado, seguindo o princípio da maior liberdade negocial para as pessoas e maior foco na fiscalização das atividades das administradoras de consórcios pelo Banco Central, pela Lei n. ${ }^{\circ} 11.795$, de 8 de outubro de 2008 (Lei n. ${ }^{\text {o } 11.795 / 08) . ~ D o ~ p o n t o ~ d e ~ v i s t a ~ e s t r u t u r a l, ~ o ~ n o v o ~ d i p l o m a ~ l e g a l ~}$ contém cinquenta e três artigos, divididos em oito capítulos. Inicia-se com a conformação do sistema de consórcios (Capítulo I), passando para a disciplina do contrato de participação no grupo de consórcio (Capítulo II), adentrando em seguida à dinâmica do funcionamento e do encerramento do grupo (Capítulo III e Capítulo IV). Há também 
esclarecimento sobre o tratamento a ser conferido aos recursos não procurados (Capítulo V) e a disciplina do funcionamento do grupo em caso de administração especial ou falência da administradora (Capítulo VI). Por fim, a Lei n. ${ }^{\circ}$ 11.795/08 enuncia as penalidades que podem ser aplicadas pelo Banco Central do Brasil (Capítulo VII) e as disposições finais costumeiras nos leis ordinárias (Capítulo VIII).

Ressalta na Lei n. ${ }^{\circ} 11.795 / 08$ um objetivo maior do que apenas disciplinar legalmente o contrato de participação em grupo de consórcio ou as diversas posições jurídicas subjetivas ativas e passivas atribuídas a cada um dos sujeitos envolvidos na operação. Está subjacente no diploma legal a estruturação do sistema de consórcios, isto é, um sistema composto por inúmeros consórcios, dotado de regras próprias (regras de identificação, regras de modificação e regras de aplicação) disciplinadoras do funcionamento dinâmico do sistema. A Lei n. ${ }^{\circ}$ 11.795/08 não cria todas as regras do sistema, fixando tão somente os fundamentos - as regras mínimas de identificação e de produção de novas regras - sobre os quais o Banco Central deve projetar, edificar e fazer funcionar o sistema de consórcios.

No tocante ao elemento substancial do sistema, o consórcio propriamente dito, a disciplina jurídica da Lei n. ${ }^{\circ}$ 11.795/08 trouxe algumas inovações bastante celebradas pelos consumidores e pelas administradoras de $\operatorname{consórcios}^{117}$ : (1) positivação do princípio de supremacia do interesse do grupo de consórcio sobre o interesse do consorciado; (2) possibilidade de formação de consórcio para a obtenção de serviços de qualquer natureza ${ }^{118}$; (3) permissão de utilização do crédito contra o grupo de consórcio para o pagamento do saldo remanescente de prestação devida em financiamento obtido pelo consorciado para aquisição do bem ou obtenção do serviço objeto do consórcio; (4) regramento da restituição das entradas realizadas pelo consorciado desistente ou excluído; e (5) qualificação do instrumento particular de contrato de participação em grupo de consórcio em título executivo extrajudicial.

Analisando as inovações trazidas pela Lei n. ${ }^{\circ}$ 11.795/08 sob a ótica do direito do consumidor, B. MiRAGEM expressa preocupação com inclusão de serviços de qualquer natureza no objeto do consórcio, um mecanismo para aquisição de bens duráveis,

117 Cf. A. M. DE Sousa FigueIREDO, ABC do Consórcio cit., pp. 31-32.

118 Comentando a inovação da criação de um segmento de serviços de qualquer natureza, A. M. DE SOUSA FIGUEIREDO explica que "poderão ser criados grupos de consórcio referenciados em serviços de qualquer natureza, isto é, poderão ser criados grupos de consórcio para financiar os estudos dos filhos, os cursos de pós-graduação, o pagamento de um implante dentário, a viagem dos sonhos, o pagamento de uma cirurgia plástica entre outros serviços" ( $A B C$ do Consórcio cit., p. 31, nota 26). 
visualizando em tal opção do legislador um desincentivo ao consumo racional e um estímulo ao superendividamento ${ }^{119}$. Embora não esclareça a relação entre consórcio para obtenção de serviços e consumo irracional e endividamento excessivo, o autor parece assumir que o fato de o mecanismo do consórcio facilitar o acesso a diversos serviços pode gerar um descontrole nos consumidores, ávidos para consumirem tantos serviços outrora inacessíveis. Sem dúvida, essa é uma possibilidade real, uma preocupação justa baseada na observação de situações nas quais a criação de uma válvula de escape para a demanda a muito reprimida gera descontrole, até mesmo uma bolha de consumo que pode prejudicar os fornecedores e consumidores. Não obstante, essa situação deve ser combatida por meio de políticas ativas de educação financeira do consumidor e não pela amputação dos serviços do objeto do consórcio. De fato, a sociedade contemporânea é uma sociedade eminentemente de serviços, os bens móveis e imóveis continuam com sua importância na dinâmica social, mas os serviços assumem uma posição impressionante como bem apto para satisfazer as necessidades e desejos das pessoas. A existência de uma demanda reprimida por tais serviços e a potencialidade de descontrole pela facilitação do acesso evidenciam o papel cada vez mais central despenhado pelos serviços nos dias atuais. Em uma sociedade liquefeita, orientada para o consumo, a realização máxima da integração no corpo social, um verdadeiro exercício de cidadania, passa a ser o ato de consumir, inclusivo e capaz de equiparar pessoas de todas as esferas e divisões da sociedade. Num mundo como esse, um mecanismo de estímulo ao consumo sem impacto inflacionário deve sem dúvida ser estimulado pelo ordenamento jurídico, apesar dos riscos de descontrole dos consumidores. Castrar o consórcio referenciado em de serviços de qualquer natureza pode significar, para muitas pessoas, inviabilizar o acesso a serviços para elas importantes simplesmente porque correm o risco de errar na dosagem e deixarem de consumir racionalmente. Seria o equívoco tantas vezes repetido na história de se definir um fenômeno, e muitas vezes proibi-lo, em razão de sua patologia, patologia essa passível de ser tratada e controlada (quando não exterminada) com outros remédios ${ }^{120}$.

119 Cf. B. MiRagem, Curso de Direito do Consumidor, 4. ${ }^{\text {a }}$ ed., rev., atual. e ampl., São Paulo, Revista dos Tribunais, p. 443.

120 Afinal, nunca pode ser perdido de vista que o enaltecimento da dignidade da pessoa humana como fundamento do Estado brasileiro (art. 1. ${ }^{\circ}$, inciso III da Constituição Federal) importa reconhecer o poder de autodeterminação das pessoas, o poder de tomar decisões e sofrer as consequências, boas ou ruins dessas decisões. A dignidade da pessoa humana, então, não se coaduna com o Estado babá, tomando conta das pessoas como se todos não passassem de bebês inaptos para tomarem decisões. Sob a ótica da dignidade da pessoa humana, o Estado babá, ainda que baseado em um governo escolhido democraticamente, não deixa de autoritário e impeditivo da autodeterminação das pessoas. Mesmo o princípio da proteção do consumidor deve ser conformado com a necessidade de o consumidor conviver e suportar os efeitos ruins de suas 
Finalmente, em 8 de fevereiro de 2009, poucos meses após o advento da Lei n. ${ }^{\circ}$ 11.795/08, o Banco Central começou a estruturar o sistema de consórcios por meio das normas jurídicas enunciadas na Circular n. 3.432 (Circular n. ${ }^{\circ}$ 3.432/09), que contém quarenta e dois artigos, organizados em dez capítulos. A preocupação do Banco Central foi criar normas suficientes para operacionalizar o sistema de consórcios e os consórcios como subsistemas elementares do sistema de consórcios, focando bastante atenção aos aspectos formais do contrato de participação em grupo de consórcio e à gestão do grupo de consórcio pela administradora de consórcios.

Após esta breve resenha histórica da disciplina do consórcio no ordenamento jurídico brasileiro, é possível identificar três eras ou etapas do desenvolvimento da instituição social denominada consórcio. De início, no período entre 1962 e 1971, havia uma ausência de normatividade específica do consórcio ${ }^{121}$, nascido da criatividade das pessoas e, por isso mesmo, acessível a qualquer um sem maiores formalidades, o que permitiu a alguns aventureiros e fraudadores atuarem entre os diversos administradores dos grupos então existentes, resultando em prejuízos consideráveis a muitos consorciados. Em seguida, o advento da Lei n. ${ }^{\circ}$ 5.768/71 deu início à segunda era do consórcio, uma era de forte normatização e até dirigismo estatal na qual até as cláusulas contratuais gerais precisavam de aprovação governamental e o sistema de consórcios era refundado a cada intervenção do Estado na economia. Por fim, a última etapa teve início em 1997, com Circular n. ${ }^{\circ} 2.766 / 97$, responsável por reduzir o engessamento do sistema, com paulatino incremento de liberdade contratual para os sujeitos e a assunção do Banco Central de uma posição de fiscalização e gerenciamento do sistema de consórcios ${ }^{122}$.

A par dos movimentos de maior ou menor normatividade e atuação estatal sobre os consórcios ao longo do tempo, ressalta ao olhar a gradual mudança da tônica subjacente às normas disciplinadoras dos consórcios, cujo enfoque inicial consistia em diferenciar o

escolhas. Não pode o ordenamento jurídico tentar remover ou excluir o "inalienável direito do cidadão de fazer tolices", mas deve criar mecanismos para impedir que "outros o fizessem de tolo" (L. Loss, Securities Regulation, vol. I, 2. ${ }^{\text {a }}$, Boston, Little Brown, 1961, p. 125).

121 Importante notar que a expressão "ausência de normatividade" não significa que o consórcio não era jurídico. Pelo contrário, era emanação do poder de autorregramento dos indivíduos na busca da satisfação de seus interesses, poder este expressamente conferido pelo ordenamento jurídico pela incidência de normas secundárias. Adicionalmente, as operações de consórcio também eram permitidas pela norma primária de conduta exclusiva, por meio da qual no campo do direito privado estão permitidas todas as condutas que não sejam expressamente proibidas. O emprego da expressão em questão possui por objetivo apontar a ausência de uma disciplina jurídica própria para o contrato de participação em grupo de consórcio e para a operação econômica como um todo.

122 Cf. F. UlhoA Coelho, Curso de Direito Civil cit., vol. III, cap. 39, item 1; D. ORFAle GiACOMINI, A Devolução cit., p. 22. 
consórcio das loterias, construído como uma exceção à vedação de sorteios pelo fato de conferir ao consorciado apenas um crédito para o recebimento do bem objeto do consórcio. Com tal construção, acrescida da certeza de contemplação de todos os consorciados ao longo da vida do grupo, pareceu totalmente justificável ao legislador permitir e tutelar o consórcio e seu mecanismo de sorteio para atribuição do crédito. Aos poucos, por força dos problemas e conflitos surgidos na prática do consórcio, a relação entre consórcio e sorteio começou a ser secundária, pois o primeiro plano, a necessidade premente era disciplinar a atuação das administradoras de consórcio, a gestão do grupo de consórcio e a abusividade das cláusulas contratuais do contrato de participação em grupo de consórcio.

Uma vez delimitadas as noções gerais envolvendo o consórcio e compreendido seu importante papel histórico, surgindo do seio da sociedade para galgar o posto de importante catalisador do consumo, a seção seguinte observará a dinâmica do funcionamento prático do consórcio. 


\section{O FUNCIONAMENTO PRÁTICO DO CONSÓRCIO}

Esta seção objetiva compreender a operação econômica consorcial por meio da descrição sumária do funcionamento prático do consórcio, iniciando pelo papel da sociedade administradora de grupos de consórcio, forma de participação no grupo de consórcio, modo de cálculo da entrada mensal do consorciado, a realização da assembleia geral de constituição, as assembleias de contemplação e as regras para utilização do crédito, para exclusão do consorciado e para restituição das entradas pelo consorciado desistente.

\subsection{A sociedade administradora de grupos de consórcio}

$\mathrm{Na}$ análise do funcionamento do consórcio, o primeiro olhar deve ser voltado à administradora de grupos de consórcio, pois é ela quem analisa mercadologicamente os anseios dos consumidores pelos bens e pelos serviços, estuda a viabilidade e as condições mínimas para funcionamento saudável de determinado grupo e as expectativas de lucratividade, elabora as cláusulas do contrato de participação em grupo de consórcio, elabora o projeto de regulamento do grupo, faz os esforços de colocação das cotas do grupo, analisa o perfil dos interessados e escolhe quem pode participar do grupo, organiza a assembleia geral de constituição, calcula o valor das entradas mensais dos consorciados, organiza e realiza as assembleias gerais ordinárias, faz a gestão dos recursos do grupo de consórcio, faz os pagamentos necessários em favor do grupo e representa-o ativa e passivamente em juízo.

A administradora de grupos de consórcio é pessoa jurídica de direito privado, organizada na forma de sociedade limitada ou sociedade por ações, cuja constituição e funcionamento foram devidamente autorizados pelo Banco Central ${ }^{123}$, com objeto

\footnotetext{
123 A Lei n. ${ }^{\text {1 }}$ 11.795/08 exige a aprovação prévia do Banco Central apenas para o funcionamento das administradoras de grupos de consórcio, silenciando a respeito da necessidade de tal aprovação na constituição. O Banco Central, por meio Circular n. ${ }^{\circ} 3.433$, de 3 de fevereiro de 2009 (Circular n. ${ }^{\circ} 3.433 / 09$ ), pautando-se no poder legal de aprovar os atos societários das administradoras de grupos de consórcios (art. 7..$^{\circ}$, inciso II da Lei n. $\left.{ }^{\circ} 11.795 / 08\right)$, condicionou o funcionamento da sociedade administradora de grupos de consórcios à constituição em conformidade com o procedimento previsto na referida circular, o que inclui a aprovação prévia dos atos constitutivos (art. 7. ${ }^{\circ}$, inciso I da Circular n. ${ }^{\circ} 3.433 / 09$ ).
} 
societário principal (o escopo-meio da sociedade ${ }^{124}$ ) de atividades de administração de grupos de consórcio (art. 5. ${ }^{\circ}$, caput e art. $7 .^{\circ}$, inciso I da Lei n. $.^{\circ} 11.795 / 08^{125}$ ), podendo exercer atividades secundárias compatíveis com a administração de grupos de consórcio, como a prestação de serviços a terceiros de colocação de cotas de outras administradoras de consórcio, a administração de grupos de outras administradoras de consórcio e a realização de serviços de cadastro, de pesquisa e de consultoria a outras administradoras de consórcio (art. 3. $.^{\circ} \S 1 .^{\circ}$ da Circular n. ${ }^{\circ} 3.433$, de 3 de fevereiro de $2009^{126}$ ).

Consoante o procedimento para constituição, os interessados em constituir uma sociedade administradora de grupos de consórcio, pessoas naturais ou coletivas, deverão apresentar pedido dirigido ao Banco Central contendo uma série de documentos previstos no Anexo da Circular n. ${ }^{\circ} 3.433 / 09$, incluindo a minuta final de contrato societário ou de estatuto societário, publicação de declaração de propósito dos fundadores e controladores, o plano de negócios e comprovação da origem dos recursos a serem aportados na integralização do capital social (art. 8. ${ }^{\circ}$, art. 27 e art. 28 da Circular n. ${ }^{\circ}$ 3.433/09).

A Circular n. ${ }^{\circ}$ 3.433/09 prevê um valor mínimo de patrimônio líquido ajustado de quatrocentos mil reais para as sociedades administradoras de grupos de consórcio referenciados em bens móveis e serviços e de um milhão de reais para as administradoras de grupos para aquisição de bens imóveis, não apenas no momento de constituição da sociedade administradora de grupos de consórcio, mas durante toda a sua vida (art. $6 .^{\circ}$ da Circular n. $\left.{ }^{\circ} 3.433 / 09^{127}\right)$.

124 Cf. E. Valladẽo AzeVedo e Novaes FranÇa - M. VieIRA VON AdAMeK, "Affectio Societatis": um Conceito Jurídico Superado no Moderno Direito Societário pelo Conceito de "Fim Social", in E. Valladẽo Azevedo e Novaes FrançA, Temas de Direito Societário, Falimentar e Teoria da Empresa, São Paulo, Malheiros, 2009, p. 43 e ss.

${ }_{125}$ "Art. 5ำ A administradora de consórcios é a pessoa jurídica prestadora de serviços com objeto social principal voltado à administração de grupos de consórcio, constituída sob a forma de sociedade limitada ou sociedade anônima, nos termos do art. $7^{\circ}$, inciso I.

Art. 7o Compete ao Banco Central do Brasil:

I - conceder autorização para funcionamento, transferência do controle societário e reorganização da sociedade e cancelar a autorização para funcionar das administradoras de consórcio, segundo abrangência e condições que fixar".

126 "Art. 3. ${ }^{\circ}$

$\S 1^{\mathrm{o}}$ As atividades que podem ser desempenhadas pela administradora de consórcio devem restringir-se às compatíveis com a administração de grupos de consórcio, assim consideradas aquelas referentes à prestação de serviços a terceiros mediante a venda e colocação de cotas de outras administradoras de consórcio, a administração de grupos de outras administradoras de consórcio e a realização de serviços de cadastro, pesquisas e consultoria a outras administradoras de consórcio, devendo constar obrigatoriamente no objeto social"”.

127 "Art. $6^{\circ}$ Os seguintes padrões mínimos de capital realizado e de Patrimônio Líquido Ajustado (PLA) devem ser permanentemente observados pelas administradoras de consórcio:

I - R $\$ 400.000,00$ (quatrocentos mil reais), para administração de grupos referenciados em bens móveis e serviços; 
Após a comunicação aos interessados a respeito da obtenção da aprovação para constituição da sociedade administradora de grupos de consórcio aos interessados, esses deverão celebrar o contrato societário ou realizar a assembleia geral de constituição e providenciar o registro do instrumento particular documentando o ato de constituição no Registro de Empresas Mercantis, a cargo das Juntas Comerciais Estaduais, e instruir o processo para obtenção de autorização de funcionamento no prazo de noventa dias contados da manifestação favorável do regulador, podendo o prazo ser prorrogado por até noventa dias por decisão do Banco Central, em resposta a pedido justificado dos interessados (art. 9. ${ }^{\circ}$ da Circular n. $.^{\circ} 3.433 / 09^{128}$ ).

A sociedade administradora de grupos de consórcio deve, necessariamente, figurar no contrato de participação em grupo de consórcio como "gestora dos negócios dos grupos e de mandatária de seus interesses e direitos" (Lei n. ${ }^{\circ} 11.795 / 08$, art. 5. ${ }^{\circ}, \S 1 .^{{ }^{129}}$ ), fazendo jus a uma remuneração adequada pela formação, pela constituição, pela organização e pela gestão do grupo de consórcio, cobrada na forma de taxa de administração (art. $5 .^{\circ}, \S 3 .^{\circ}$ da Lei n. ${ }^{\circ} 11.795 / 08^{130}$ ).

No funcionamento prático do consórcio, a sociedade administradora de grupos de consórcio assume a titularidade formal dos recursos entregues pelos consorciados, imóveis.

II - R \$1.000.000,00 (um milhão de reais), para administração de grupos referenciados em bens

$\S 1^{\circ}$ O PLA é obtido pela soma algébrica dos seguintes grupos integrantes do Plano Contábil das Instituições do Sistema Financeiro Nacional (Cosif):

(+) 6.0.0.00.00-2 Patrimônio Líquido;

(+) 7.0.0.00.00-9 Contas de Resultado Credoras;

(-) 8.0.0.00.00-6 Contas de Resultado Devedoras.

$\S 2^{\circ}$ A observância do disposto neste artigo é condição indispensável para o funcionamento das administradoras de consórcio.

$\S 3^{\circ}$ As insuficiências de capital realizado e de PLA eventualmente verificadas em decorrência das disposições desta circular deverão ser eliminadas até 31 de dezembro de 2009".

${ }_{128}$ "Art. $9^{\circ}$ Uma vez atendidas as providências estabelecidas no art. $8^{\circ}$ e obtida a manifestação favorável do Banco Central do Brasil em relação ao projeto de constituição da administradora de consórcio, os interessados devem formalizar os atos societários de constituição da sociedade e instruir o processo relativo ao pedido de autorização para funcionamento, nos termos do art. 27, no prazo máximo de noventa dias, contado do recebimento da respectiva comunicação, cuja inobservância ensejará o arquivamento do processo.

Parágrafo único. Mediante pedido justificado, pode ser concedido prazo adicional de até noventa dias, findo o qual, não adotadas as providências pertinentes, o processo será automaticamente arquivado". 129 "Art. 5."

$\S 1^{0}$ A administradora de consórcio deve figurar no contrato de participação em grupo de consórcio, por adesão, na qualidade de gestora dos negócios dos grupos e de mandatária de seus interesses e direitos".

${ }_{130}$ "Art. 5. ${ }^{\circ}$

$\S 3^{\mathrm{o}}$ A administradora de consórcio tem direito à taxa de administração, a título de remuneração pela formação, organização e administração do grupo de consórcio até o encerramento deste, conforme o art. 32, bem como o recebimento de outros valores, expressamente previstos no contrato de participação em grupo de consórcio, por adesão, observados ainda os arts. 28 e 35". 
depositados em conta vinculada em nome da administradora em banco múltiplo com carteira comercial, banco comercial ou caixa econômica (art. $6 .^{\circ}$ da Circular n. ${ }^{\circ}$ 3.432/09 ${ }^{131}$ ), e dos bens e direitos dados em garantia pelos consorciados contemplados, não havendo comunicação entre as posições jurídicas subjetivas ativas e passivas do grupo de consórcio e a as demais posições jurídicas subjetivas ativas e passivas integrantes da esfera jurídica da sociedade administradora de grupos de consórcio (art. $5 .^{\circ}, \S 5 .^{\circ}, \S 6 .^{\circ}$ e $\S 7 .^{\circ}$ da Lei n. ${ }^{\circ} 11.795 / 08^{132}$ ).

\subsection{Contrato de participação em grupo de consórcio}

A participação dos consorciados no grupo de consórcio ocorre por meio da celebração do contrato de participação em grupo de consórcio, legalmente conceituado como contrato plurilateral por adesão cujo objeto é constituição de um fundo pecuniário a

131 "Art. $6^{\text {o }}$ Os recursos dos grupos de consórcio, coletados pelas administradoras, devem ser obrigatoriamente depositados em banco múltiplo com carteira comercial, banco comercial ou caixa econômica.

$\S 1^{\mathrm{o}}$ A administradora de consórcio deve efetuar o controle diário da movimentação das contas componentes das disponibilidades dos grupos de consórcio, inclusive os depósitos bancários, com vistas à conciliação dos recebimentos globais, para a identificação analítica por grupo de consórcio e por consorciado contemplado cujos recursos relativos ao crédito estejam aplicados financeiramente.

$\S 2^{\circ}$ Os recursos de que trata o caput somente podem ser aplicados em títulos públicos federais registrados no Sistema Especial de Liquidação e de Custódia (Selic), em fundos de investimentos e em fundos de investimentos em cotas de fundos de investimentos constituídos sob a forma de condomínio aberto, classificados como fundos de curto prazo e fundos referenciados, nos termos da Instrução CVM nº 409, de 18 de agosto de 2004, e alterações posteriores, da Comissão de Valores Mobiliários (CVM), vedada a aplicação de recursos:

I - da própria administradora no mesmo fundo de investimento;

II - em fundos exclusivos;

III - em fundos destinados exclusivamente a investidores qualificados”.

132 " $\$ 5^{\circ}$ Os bens e direitos adquiridos pela administradora em nome do grupo de consórcio, inclusive os decorrentes de garantia, bem como seus frutos e rendimentos, não se comunicam com o seu patrimônio, observado que:

I - não integram o ativo da administradora;

II - não respondem direta ou indiretamente por qualquer obrigação da administradora;

III - não compõem o elenco de bens e direitos da administradora, para efeito de liquidação judicial ou extrajudicial;

IV - não podem ser dados em garantia de débito da administradora.

$\S 6^{\circ}$ A administradora estará desobrigada de apresentar certidão negativa de débitos, expedida pelo Instituto Nacional da Seguridade Social, e Certidão Negativa de Tributos e Contribuições, expedida pela Secretaria da Receita Federal, relativamente à própria empresa, quando alienar imóvel integrante do patrimônio do grupo de consórcio.

$\S 7^{\underline{0}}$ No caso de o bem recebido ser um imóvel, as restrições enumeradas nos incisos II a IV do $\S$ $5^{\circ}$ deste artigo deverão ser averbadas no registro de imóveis competente". 
ser utilizado na aquisição de bens ou obtenção de serviços (art. 10 da Lei n. ${ }^{0} 11.795 / 08^{133}$ ), por meio do qual se constrói um regramento próprio de cada grupo de consórcio, com a atribuição de posições jurídicas subjetivas ativas e passivas, simples ou complexas a cada membro do grupo de consórcio, consubstanciadas em uma cota atribuída ao participante (art. 11 da Lei n. ${ }^{o} 11.795 / 08^{134}$ ).

É essencial para o correto desenvolvimento e adimplemento da relação resultante do contrato de participação em grupo de consórcio, a identificação do bem, móvel ou imóvel, ou do serviço a que o contrato está referenciado (art. 12 da Lei n. ${ }^{\text {o }} 11.795 / 08^{135}$ ) e seu respectivo preço ou valor de retribuição na data da celebração do contrato, pois esse valor será ulteriormente utilizado para determinação da carta de crédito e para o cálculo das parcelas mensais dos consorciados.

O número total de cotas deve ser fixado no contrato de participação no grupo e não pode ser alterado após a constituição do grupo de consórcio (art. $7 .^{\circ}, \S 3 .^{\circ}$ da Circular n. ${ }^{\circ}$ $3.432 / 09^{136}$ ) e nenhum consorciado pode ser titular de um número de cotas que represente mais do que dez por cento do total das cotas ativas do grupo (art. $7 .^{\circ}, \S 4 .^{\circ}$ da Circular n. ${ }^{\circ}$ $\left.3.432 / 09^{137}\right)$. A administradora do grupo, coligadas, controladas e controladoras da administradora do grupo, bem como os respectivos administradores e pessoas com funções de gestão podem adquirir cotas do grupo, limitado a dez por cento do total das cotas ativas,

133 “Art. 10. O contrato de participação em grupo de consórcio, por adesão, é o instrumento plurilateral de natureza associativa cujo escopo é a constituição de fundo pecuniário para as finalidades previstas no art. $2^{\underline{0}}$.

$\S 1^{\circ}$ O contrato de participação em grupo de consórcio, por adesão, criará vínculos obrigacionais entre os consorciados, e destes com a administradora, para proporcionar a todos igual condição de acesso ao mercado de consumo de bens ou serviços.

$\S 2^{\underline{0}}$ (VETADO)

$\S 3^{0}$ A proposta de participação é o instrumento pelo qual o interessado formaliza seu pedido de participação no grupo de consórcio, que se converterá no contrato, observada a disposição constante do $\S 4^{\circ}$, se aprovada pela administradora.

$\S 4^{\underline{0}} \mathrm{O}$ contrato de participação em grupo de consórcio aperfeiçoar-se-á na data de constituição do grupo, observado o art. 16.

$\S 5^{\mathrm{o}}$ É facultada a estipulação de multa pecuniária em virtude de descumprimento de obrigação contratual, que a parte que lhe der causa pagará à outra.

$\S 6^{\circ} \mathrm{O}$ contrato de participação em grupo de consórcio, por adesão, de consorciado contemplado é título executivo extrajudicial".

134 “Art. 11. O contrato de participação em grupo de consórcio, por adesão, implicará atribuição de uma cota de participação no grupo, numericamente identificada, nela caracterizada o bem ou serviço".

135 "Art. 12. O contrato de participação em grupo de consórcio, por adesão, poderá ter como referência bem móvel, imóvel ou serviço de qualquer natureza".

136 "Art. 7.

§ 3. ${ }^{\circ}$ O número de cotas do grupo, fixado na data de sua constituição, não pode ser alterado ao longo de sua duração".

"Art. 7."

$\S 4^{\circ} \mathrm{O}$ percentual de cotas de um mesmo consorciado em um mesmo grupo em relação ao número máximo de cotas de consorciados ativos do grupo fica limitado a 10\% (dez por cento)". 
mas só concorrem a sorteio ou lance após a contemplação de todos os demais consorciados (art. 15, § 1. ${ }^{\mathrm{o}}$ da Lei n. ${ }^{\mathrm{o}} 11.795 / 08^{138}$ ).

Pode ser previsto no contrato de participação no grupo o pagamento, no ato da adesão do participante ao grupo, da primeira entrada para o fundo comum e para o fundo de reserva e o pagamento de antecipação da taxa de administração, com relação às despesas imediatas vinculadas à venda de cotas de grupo de consórcio e remuneração de representantes e corretores. Todavia, caso o grupo não venha a constituir-se no prazo de noventa dias contados da adesão, a administradora restituirá ao aderente os valores cobrados, acrescidos dos rendimentos líquidos provenientes de sua aplicação financeira

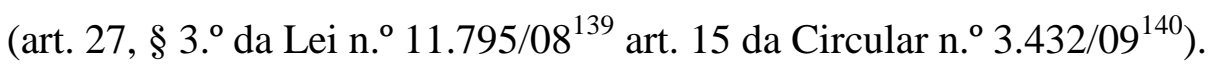

Além do contrato de participação no grupo de consórcio, a administradora do grupo também é responsável pela formulação do regulamento do grupo de consórcio, cujo instrumento deve ser levado registrado no ofício de títulos e documentos da sede da administradora do consórcio, que contém regras para o funcionamento diário do grupo de consórcio e detalha os procedimentos previstos no contrato para o relacionamento dos consorciados entre si e do grupo com a administradora do grupo de consórcio (art. $4 .^{\circ}$ da Circular n. ${ }^{\circ} 3.432 / 09^{141}$ ).

138 "Art. 15. administração.

$\S 1^{\mathrm{o}}$ A administradora de consórcio pode adquirir cotas de grupo de consórcio, inclusive sob sua

$\S 2^{\underline{0}}$ A administradora de consórcio, em qualquer hipótese, somente poderá concorrer a sorteio ou lance após a contemplação de todos os demais consorciados".

139 "Art. 27.

$\S 3^{\mathrm{o}}$ É facultado estipular no contrato de participação em grupo de consórcio, por adesão, a cobrança de valor a título de antecipação de taxa de administração, destinado ao pagamento de despesas imediatas vinculadas à venda de cotas de grupo de consórcio e remuneração de representantes e corretores, devendo ser:

I - destacado do valor da taxa de administração que compõe a prestação, sendo exigível apenas no ato da assinatura do contrato de participação em grupo de consórcio, por adesão;

140 II - deduzido do valor total da taxa de administração durante o prazo de duração do grupo".

140 "Art. 15. É facultado à administradora, desde que previsto contratualmente, cobrar do consorciado no ato de sua adesão a grupo de consórcio:

I - a primeira prestação;

II - a antecipação de recursos relativos à taxa de administração.

$\S 1^{\circ}$ Não constituído o grupo no prazo de noventa dias, a partir do primeiro dia útil seguinte a esse prazo, a administradora deve devolver ao aderente os valores cobrados, acrescidos dos rendimentos líquidos provenientes de sua aplicação financeira.

$\S 2^{\circ}$ As despesas com auditoria independente das demonstrações financeiras dos grupos de consórcio são de responsabilidade da administradora de consórcio".

$141 \quad$ "Art. $4^{\circ} \mathrm{O}$ regulamento do grupo de consórcio deve:

I - ser registrado em cartório de registro de títulos e documentos da localidade em que instalada a sede da administradora; 
Poderá prever o contrato de participação em grupo de consórcio que o aderente deverá, na data de sua adesão, realizar a primeira entrada para a formação do fundo comum e pagar taxa de adesão, a ser posteriormente descontada da taxa de administração. Os recursos serão recebidos pela sociedade administradora a título de depósito e deverão ser restituídos se o grupo de consórcio não se constituir no prazo de noventa dias (art. $27, \S 3$. $^{\circ}$ da Lei n. ${ }^{\circ} 11.795 / 08^{142}$; art. 15, da Circular n. ${ }^{\circ} 3.432 / 09^{143}$ ).

A adesão ao contrato de participação no grupo de consórcio não precisa, necessariamente, ocorrer antes da constituição do grupo. É perfeitamente possível, e faz parte do sistema, a cessão da posição contratual e a consequente transferência da cota para um terceiro, desde que haja o consentimento da administradora nesse sentido (art. 13 da Lei $11.975 / 08^{144}$ ). Faz sentido vincular a cessão da posição contratual (e de quaisquer posições jurídicas subjetivas ativas e passivas) ao consentimento da administradora, visto que cabe a ela zelar pela estabilidade econômico-financeira do grupo e analisar a possibilidade de cada consorciado cumprir pontualmente suas prestações.

Com relação ao mecanismo de participação no grupo de consórcio, é preciso lembrar que, de acordo com o modelo legal da operação de consórcio, a iniciativa de constituição do grupo de consórcio é da sociedade administradora de grupos de consórcio, pois é ela quem analisa o interesse dos consumidores, estrutura a viabilidade econômicofinanceira do grupo de consórcio em projeto, busca as tabelas oficiais dos fornecedores ou calcula o preço de mercado do bem ou serviço objeto do consórcio, predispõe as cláusulas

II - ser arquivado na sede da administradora, mantida a respectiva cópia autenticada nas filiais da administradora e nas dependências de empresa conveniada, se houver, à disposição dos consorciados e do Banco Central do Brasil".

142 "Art. 27.

$\S 3^{\mathrm{o}}$ É facultado estipular no contrato de participação em grupo de consórcio, por adesão, a cobrança de valor a título de antecipação de taxa de administração, destinado ao pagamento de despesas imediatas vinculadas à venda de cotas de grupo de consórcio e remuneração de representantes e corretores, devendo ser:

I - destacado do valor da taxa de administração que compõe a prestação, sendo exigível apenas no ato da assinatura do contrato de participação em grupo de consórcio, por adesão;

II - deduzido do valor total da taxa de administração durante o prazo de duração do grupo".

143 “Art. 15. É facultado à administradora, desde que previsto contratualmente, cobrar do consorciado no ato de sua adesão a grupo de consórcio:

I - a primeira prestação;

II - a antecipação de recursos relativos à taxa de administração.

$\S 1^{\circ}$ Não constituído o grupo no prazo de noventa dias, a partir do primeiro dia útil seguinte a esse prazo, a administradora deve devolver ao aderente os valores cobrados, acrescidos dos rendimentos líquidos provenientes de sua aplicação financeira.

$\S 2^{\circ}$ As despesas com auditoria independente das demonstrações financeiras dos grupos de consórcio são de responsabilidade da administradora de consórcio".

144 "Art. 13. Os direitos e obrigações decorrentes do contrato de participação em grupo de consórcio, por adesão, poderão ser transferidos a terceiros, mediante prévia anuência da administradora”. 
contratuais do contrato de participação em grupo de consórcio, define o regulamento do grupo de consórcio, faz a colocação das cotas, analisa o perfil de risco de cada prospectivo consorciado, coleta os recursos e gere o grupo de consórcio ${ }^{145}$.

\subsection{Constituição do grupo de consórcio}

De acordo com o conceito legal, o grupo de consórcio ${ }^{146}$ é uma sociedade não personificada, com prazo de duração ${ }^{147}$, constituída por consorciados (= partes do contrato de participação em grupo de consórcio), com a finalidade de proporcionar aos seus membros, de maneira isonômica, a aquisição de bens ou a obtenção de serviços (Lei n. ${ }^{\circ}$ 11.795/08, art. 3. ${ }^{{ }^{148}}$, caput; art. $2 .^{{ }^{149}}$ ). O grupo de consórcio é representado ativa e passivamente, judicial ou extrajudicialmente, pela sociedade administradora (Lei n. ${ }^{\circ}$ $11.795 / 08$, art. $3 .^{\circ}, \S 1 .^{{ }^{150}}$ ), cada grupo de consórcio é autônomo em relação aos demais grupos, dotado de patrimônio próprio, sem relação com o patrimônio de outros grupos ou da administradora (art. 3. ${ }^{\circ}, 33^{\circ}$ da Lei n. ${ }^{o} 11.795 / 08^{151}$ ), que deverá contabilizar os ativos

145 Cf. F. Ulho Coelho, Curso de Direito Civil cit., vol. III, cap. 39, item 2.

146 F. FERNANDES RIBEIRO MAIA critica o emprego da expressão "grupo de consórcio" pela Lei n. ${ }^{\circ}$ $11.795 / 08$, pois entende que "o grupo, isto é, aquelas pessoas naturais ou jurídicas reunidas pela administradora, é um grupo de consorciados, que são estas pessoas e, logo, não é um grupo de 'consórcio'. $O$ consórcio é o sistema e não as pessoas que participam dos planos de consórcios geridos pela administradora (pessoa jurídica prestadora de serviços, conforme art. 5. da Lei 11.795/2008)" (Cf. O Sistema de Consórcio Financeiro na Lei 11.795/2008 cit., pp. 66 e ss.).

147 Tecnicamente, o prazo é o lapso de tempo transcorrido entre um termo inicial e um termo final. A existência de um termo inicial e de um termo final faz com que o prazo, necessariamente, seja determinado. Não existe prazo indeterminado. O prazo indeterminado é um não prazo. A indeterminação é do tempo e não do prazo. Assim, o correto é dizer "tempo indeterminado". Por outro lado, como todo prazo é um lapso de tempo determinado por dois termos, falar em "prazo indeterminado" é incorrer em vício de linguagem reprovável (Cf. A. TomasetTi JR., Teoria Geral do Direito Privado, Mimeo, 2004).

"Art. $3^{\mathrm{o}}$ Grupo de consórcio é uma sociedade não personificada constituída por consorciados para os fins estabelecidos no art. $2^{\mathrm{o}}$ ".

149 “Art. $2^{\underline{0}}$ Consórcio é a reunião de pessoas naturais e jurídicas em grupo, com prazo de duração e número de cotas previamente determinados, promovida por administradora de consórcio, com a finalidade de propiciar a seus integrantes, de forma isonômica, a aquisição de bens ou serviços, por meio de autofinanciamento".

150 "Art. 3.

$\S 1^{\text {o }}$ O grupo de consórcio será representado por sua administradora, em caráter irrevogável e irretratável, ativa ou passivamente, em juízo ou fora dele, na defesa dos direitos e interesses coletivamente considerados e para a execução do contrato de participação em grupo de consórcio, por adesão".

151 "Art. 3.

§ 3. $\quad$ O grupo de consórcio é autônomo em relação aos demais e possui patrimônio próprio, que não se confunde com o de outro grupo, nem com o da própria administradora". 
e passivos dos grupos de maneira separada e individualizada (art. $3 .^{\circ}, \S 4 .^{\circ}$ da Lei $n .^{\circ}$ $\left.11.795 / 08^{152}\right)$.

Questão de suma importância na correta compreensão do contrato de participação em grupo de consórcio e ainda pendente de definição clara consiste na natureza jurídica do grupo de consórcio, conceituado pela norma legal como "sociedade não personificada". Seguindo o entendimento anterior à Lei n. ${ }^{\circ} 11.795 / 08$, M. HelEnA DinIz ${ }^{153}$, M. A. DE SOUSA FIGUEIREDO ${ }^{154}$ e D. GIACOMINI ${ }^{155}$ sustentam que o grupo de consórcio é uma sociedade de fato ${ }^{156}$, enquanto F. UlHOA COELHO ${ }^{157}$ entende que a Lei n. ${ }^{\text {o }}$ 11.795/08 disciplinou a operação de consórcio sem tipificar as diversas posições jurídicas subjetivas, relegando o grupo de consórcio a um conceito sui generis, mais próximo do patrimônio separado ou patrimônio de afetação, de modo que o regime jurídico a ser aplicado, por analogia, é o da sociedade em comum. Por outro lado, F. FERNANDES RIBEIRO MAIA ${ }^{158}$ faz duras críticas à redação legal, pois entende que a sociedade é um tipo de pessoa jurídica na qual os sócios se unem para exercer uma atividade em comum com a finalidade de obter um resultado positivo a ser distribuído entre os sócios. Em sua concepção, os consorciados não se unem, são reunidos pela administradora de grupos de consórcio com a finalidade de solidariedade e de ajuda mútua, uma verdadeira união de pessoas com fins não lucrativos, caracterizadora de uma associação de fato não passível de registro e de personificação ${ }^{159}$.

\footnotetext{
152 "Art. 3.

$\S 4^{0}$ Os recursos dos grupos geridos pela administradora de consórcio serão contabilizados separadamente. ".

$153 \quad$ Cf. Tratado Teórico e Prático dos Contratos cit., p. 265.

$154 \quad$ Cf. $A B C$ do Consórcio cit., p. 33.

155 Cf. A Devolução cit., p. 107.

156 Conforme demonstrou E. VALLADÃo AZEVEDO E NOVAES FRANÇA, o emprego da expressão "sociedade de fato" entre os autores designa situações distintas, tendo autores que associam a facticidade com a falta de prova escrita da constituição da sociedade, enquanto outros bebem na fonte do direito francês para sustentar que a sociedade de fato é aquela na qual os sócios desconhecem sua situação de participantes de uma sociedade e por fim aqueles que relacionavam a sociedade de fato com a sociedade irregular, cujos documentos dos atos constitutivos não foram levados a registro (Cf. A Sociedade em Comum, São Paulo, Malheiros, pp. 25-52; 105-113). Os autores citados no texto, embora não esclareçam sua posição, aparentemente consideram o grupo de consórcio uma sociedade de fato pela inexistência de registro no Registro Público de Empresas Mercantis a cargo das Juntas Comerciais ou no Ofício de Registro Civil de Pessoas Jurídicas. Esta concepção de sociedade de fato é equivocada, caindo na vala comum de confundir a sociedade com a personalidade jurídica decorrente do registro. A sociedade é efeito do negócio jurídico plurilateral organizativo societário e como tal ela sempre é uma realidade jurídica, sendo descabido falar em sociedade de fato e sociedade de direito. Se há contrato societário existente, válido e eficaz, há sociedade reconhecida e constituída pelo ordenamento jurídico, sociedade de direito. Se a sociedade é ou não registrada ou se ela pode ou não gozar de personificação é uma análise a ser feita em outro momento.

157 Cf. Curso de Direito Civil cit., vol. III, cap. 39, item 3.3.3.

158 Cf. O Sistema de Consórcio Financeiro na Lei 11.795/2008 cit., pp. 66 e ss.

159 O equívoco da expressão "associação de fato" é semelhante ao equívoco da locução "sociedade de fato", e pode ser repelida com idênticos argumentos.
} 
Já A. D. MALFATTI ${ }^{160}$ não visualiza a estabilidade organizacional necessária para que o grupo de consórcio seja uma sociedade ou uma associação, defendendo "quando se forma um grupo de consórcio, ocorreu a reunião acidental - dentro de uma estratégia de mercado conveniente para as partes e sem nenhuma confiança ou vínculo semelhante". Neste momento, basta mencionar as diferentes concepções a respeito da natureza jurídica do grupo de consórcios, visto que o tema deverá ser retomado posteriormente na análise da qualificação do contrato de participação em grupo de consórcios.

Somente entrará em funcionamento o grupo de consórcio após a realização da primeira assembleia geral, convocada pela administradora uma vez que sejam atingidas as adesões necessárias para a viabilidade econômico-financeira do grupo de consórcio (art. 16 da Lei n. $\left.{ }^{\circ} 11.795 / 08^{161}\right)$. Na assembleia geral de constituição, deverá a administradora comprovar a viabilidade do grupo e fornecer as informações sobre o auditor independente contratado para verificar as contas do grupo. Adicionalmente, os consorciados elegerão até três representantes que atuarão junto à administradora com a finalidade de acompanhar a regularidade da gestão, escolherão a modalidade de aplicação financeira mais adequada para os recursos coletados e deliberarão sobre a necessidade de abertura de conta individualizada para o grupo (art. 34 da Circular n. ${ }^{\circ} 3.432 / 09^{162}$; art. 17 da Lei n. ${ }^{\circ}$ $\left.11.795 / 08^{163}\right)$.

160 Cf. O Contrato de Consórcio e o Direito do Consumidor, após a Vigência da Lei 11.795/2008, Revista de Direito do Consumidor, no 70, São Paulo, RT, 2009, pp. 13-14.

161 "Art. 16. Considera-se constituído o grupo de consórcio com a realização da primeira assembléia, que será designada pela administradora de consórcio quando houver adesões em número e condições suficientes para assegurar a viabilidade econômico-financeira do empreendimento".

162 “Art. 34. Na primeira assembléia geral ordinária do grupo, a administradora deve:

I - comprovar a existência de recursos suficientes para assegurar a viabilidade econômico-financeira do grupo, nos termos do art. $7^{\circ}$;

II - promover a eleição dos consorciados representantes do grupo, com mandato não remunerado, não podendo concorrer à eleição funcionários, sócios, gerentes, diretores e prepostos com poderes de gestão da administradora ou das empresas a ela ligadas, promovendo-se nova eleição, na próxima assembléia geral, para substituição dos representantes em caso de renúncia, contemplação, exclusão da participação no grupo ou outras situações que gerarem impedimento, após a ocorrência ou conhecimento do fato pela administradora;

III - fornecer todas as informações necessárias para que os consorciados possam decidir quanto à modalidade de aplicação financeira mais adequada para os recursos coletados, bem como sobre a necessidade ou não de conta individualizada para o grupo;

IV - registrar na ata o nome e o endereço dos responsáveis pela auditoria externa contratada e, quando houver mudança, anotar na ata da assembléia seguinte ao evento os dados relativos ao novo auditor.

Parágrafo único. O consorciado pode retirar-se do grupo em decorrência da não observância do disposto no caput, desde que não tenha concorrido à contemplação, hipótese em que lhe serão devolvidos os valores por ele pagos a qualquer título, acrescidos dos rendimentos financeiros líquidos provenientes de sua aplicação financeira".

163 "Art. 17. O grupo deve escolher, na primeira assembléia geral ordinária, até 3 (três) consorciados, que o representarão perante a administradora com a finalidade de acompanhar a regularidade de sua gestão, 
Os critérios de viabilidade econômico-financeira para a constituição do grupo são arrolados no art. $7 .^{\circ}$ da Circular n. $.^{\circ} 3.432 / 09^{164}$ : (1) existência de recursos suficientes, na data da primeira assembleia geral ordinária, considerados os créditos de maior valor do grupo, para a realização do número de contemplações via sorteio previsto contratualmente para o período; e (2) da possibilidade de pagamento dos proponentes, relativamente às prestações assumidas perante o grupo e a administradora.

O grupo de consórcio pode ser homogêneo ou heterogêneo dependendo da existência de valores diferenciados de categorias ou não. Denomina-se valor da categoria a soma do valor do crédito na data da assembleia geral ordinária com o valor total da taxa de administração e do valor total do fundo de reserva. Um mesmo grupo de consórcio pode ter categorias diversas de consorciados na medida em que alguns consorciados farão jus a um crédito correspondente a cem por cento do valor do bem ou do serviço, enquanto outros fazem jus a um percentual menor. Unificando o grupo de consórcio está o bem ou o serviço e não o percentual de referência de cada consorciado. De fato, desde que fosse possível assegurar a viabilidade econômico-financeira do grupo, nada impediria formar um grupo de consórcio onde os créditos de cada consorciado correspondem a percentuais diferentes do preço do bem a ser comprado ou do valor da retribuição do serviço a ser obtido.

com mandato igual à duração do grupo, facultada a substituição por decisão da maioria dos consorciados em assembléia geral.

Parágrafo único. No exercício de sua função, os representantes terão, a qualquer tempo, acesso a todos os documentos e demonstrativos pertinentes às operações do grupo, podendo solicitar informações e representar contra a administradora na defesa dos interesses do grupo, perante o órgão regulador e fiscalizador".

164 "Art. $7^{\circ}$ A viabilidade econômico-financeira do grupo de consórcio, nos termos do art. 16 da Lei no 11.795, de 2008, pressupõe a:

I - existência de recursos suficientes, na data da primeira assembléia geral ordinária, para a realização do número de contemplações via sorteio previsto contratualmente para o período, considerados os créditos de maior valor do grupo;

II - verificação da capacidade de pagamento dos proponentes, relativamente às obrigações financeiras assumidas perante o grupo e a administradora.

$\S 1^{\circ}$ É admitida a formação de grupos em que os créditos sejam de valores diferenciados, observado que o crédito de menor valor, vigente ou definido na data da constituição do grupo, não pode ser inferior a $50 \%$ (cinquenta por cento) do crédito de maior valor.

$\S 2^{\circ}$ Para os casos de grupos resultantes da fusão de outros grupos, será admitida diferença superior à estabelecida no $\S 1^{\circ}$, desde que o procedimento atenda ao estabelecido no art. 35 , inciso II.

$\S 3^{\circ} \mathrm{O}$ número de cotas do grupo, fixado na data de sua constituição, não pode ser alterado ao longo de sua duração.

$\S 4^{\circ} \mathrm{O}$ percentual de cotas de um mesmo consorciado em um mesmo grupo em relação ao número máximo de cotas de consorciados ativos do grupo fica limitado a $10 \%$ (dez por cento)". 


\subsection{A entrada periódica do consorciado}

Por força do contrato de participação em grupo de consórcio, os participantes do consórcio ficam adstritos a efetuar entradas com certa periodicidade a um fundo comum durante determinado lapso temporal, devendo readequar-se o montante pecuniário da entrada do participante, de modo a refletir as alterações no preço de mercado do bem ou no valor da retribuição pela prestação do serviço ${ }^{165}$. A readequação do valor das entradas ${ }^{166}$ é realizada pela adoção do sistema de preço ponderado, consistindo na conversão, na data da assembleia geral, das contribuições para o fundo comum, dos lances e dos adiantamentos em percentual do valor do bem objeto do consórcio ${ }^{167}$.

A entrada periódica por parte dos consorciados acima mencionada, chamada no jargão dos consórcios de prestação mensal, não é unitária, mas pode ser composta por até quatro elementos: (1) montante destinado ao fundo comum; (2) montante destinado ao fundo de reserva; (3) importância correspondente à taxa de administração; e (4) prêmio do seguro. Como é possível perceber, são imperativas e ínsitas a todo e qualquer consórcio a pretensão ao pagamento da parcela destinada à formação do fundo comum e à taxa de administração que remunera os serviços da administradora do grupo, enquanto que a formação de fundo de reserva e o pagamento de prêmio de seguro são cláusulas negociais e podem ou não ser verificadas em determino consórcio. Consiste o fundo de reserva, como o próprio nome já diz, em provisão de recursos para a utilização em situações excepcionais, conforme regulamento do grupo de consórcio. Por sua vez, o seguro será usado para garantir o pagamento do consorciado já contemplado e inadimplente, que não pode ser excluído do grupo, ou em situação de morte de algum consorciado.

Periodicamente são realizadas assembleias gerais ordinárias do grupo de consórcio nas quais podem ocorrer as contemplações, isto é, a atribuição ao consorciado do crédito para a aquisição do bem ou a obtenção do serviço objeto do consórcio por sorteio ou lance

\footnotetext{
165 Com isso, garante-se a isonomia entre os participantes, visto que a soma total das prestações de todos os membros do grupo é idêntica, independentemente do momento no qual o participante seja contemplado.

166 Tecnicamente, os consorciados são titulares de uma dívida de valor, cuja prestação consiste na entrega de determinada soma de dinheiro equivalente ao valor do bem que serve de referência para o grupo de consórcio.

167 Cf. A. M. DE Sousa FigueIREDO, ABC do Consórcio cit., p. 45.
} 
(art. 22 da Lei n. ${ }^{\circ} 11.795 / 08^{168}$ ). Tal crédito atribuído ao consorciado corresponderá ao valor do bem ou do serviço objeto do consórcio na data da assembleia geral ordinária de contemplação, será acrescido do resultado líquido da aplicação financeira do valor no período entre a disponibilização dos recursos ao consorciado e a data de efetiva utilização desses recursos (art. 24 da Lei n. ${ }^{\circ} 11.795 / 08^{169}$ ).

Pode-se exemplificar o funcionamento geral do consórcio com a constituição de um grupo de consórcio homogêneo para aquisição de veículo automotor no valor de $\mathrm{R} \$$ 50.000,00 (cinquenta mil reais), com prazo de duração de cinco anos, com cobrança homogênea mensal das entradas do consorciado, compostas, além da contribuição para o fundo comum, de fundo de reserva total de dois por cento e taxa de administração total de vinte por cento.

$\begin{array}{lr}\text { Valor do bem: } & 50.000,00 \\ \text { Prazo de duração: } & 60 \text { meses } \\ \text { Percentual do fundo comum: } & 1^{170} \\ \text { Taxa de administração total: } & 0,2 \\ \text { Fundo de reserva total: } & 0,02 \\ \text { Periodicidade das entradas: } & \text { Mensal }\end{array}$

168 “Art. 22. A contemplação é a atribuição ao consorciado do crédito para a aquisição de bem ou serviço, bem como para a restituição das parcelas pagas, no caso dos consorciados excluídos, nos termos do art. 30 .

$\S 1^{\text {o }}$ A contemplação ocorre por meio de sorteio ou de lance, na forma prevista no contrato de participação em grupo de consórcio, por adesão.

$\S 2^{\underline{0}}$ Somente concorrerá à contemplação o consorciado ativo, de que trata o art. 21, e os excluídos, para efeito de restituição dos valores pagos, na forma do art. 30.

$\S 3^{\mathrm{o}} \mathrm{O}$ contemplado poderá destinar o crédito para a quitação total de financiamento de sua titularidade, sujeita à prévia anuência da administradora e ao atendimento de condições estabelecidas no contrato de consórcio de participação em grupo".

169 "Art. 24. O crédito a que faz jus o consorciado contemplado será o valor equivalente ao do bem ou serviço indicado no contrato, vigente na data da assembléia geral ordinária de contemplação.

$\S 1^{\circ} \mathrm{O}$ crédito de que trata este artigo será acrescido dos rendimentos líquidos financeiros proporcionais ao período que ficar aplicado, compreendido entre a data em que colocado à disposição até a sua utilização pelo consorciado contemplado.

$\S 2^{\underline{o}}$ Nos casos em que o objeto do contrato não possa ser perfeitamente identificado, o valor do crédito e a sua atualização deverão estar previstos no contrato, sem prejuízo do acréscimo dos rendimentos líquidos de que trata o $\S 1^{\underline{0}}$. parcial".

$\S 3^{0}$ A restituição ao consorciado excluído, calculada nos termos do art. 30, será considerada crédito

O consórcio pode ser formado para a captação de recursos para o pagamento tanto da totalidade como de uma parte do bem ou do serviço. No exemplo acima, o objeto é a formação de um fundo comum no valor total do veículo automotor e, por isso, a relação entre o valor total do fundo comum e o valor total do bem é de $100 \%$ ou 1 na expressão decimal. 


\title{
2.4.1. Cálculo da entrada mensal para o fundo comum
}

O cálculo de cada parcela da entrada mensal para o fundo comum é realizado com o cálculo do fator mensal de contribuição para o fundo comum, conforme fórmula abaixo:

$$
\begin{gathered}
\text { Fator mensal de fundo comum }=\frac{\text { Percentual do fundo comum }}{\text { Prazo de duração }} \\
\text { Fator mensal de fundo comum }=\frac{1}{60} \\
\text { Fator mensal de fundo comum }=0,016666667
\end{gathered}
$$

Em seguida, é possível calcular o valor da entrada mensal para o fundo comum:

\author{
Entrada mensal para o fundo comum $=$ Valor do bem $\times$ Fator mensal de fundo comum \\ Entrada mensal para o fundo comum $=50.000,00 \times 0,016666667$ \\ Entrada mensal para o fundo comum $=R \$ 833,34$
}

\subsubsection{Cálculo do valor da taxa de administração mensal}

De início, deve-se calcular o fator mensal de pagamento da taxa, conforme fórmula abaixo:

$$
\begin{gathered}
\text { Fator mensal da taxa de administração }=\frac{\text { Taxa de administração total }}{\text { Prazo de duração }} \\
\text { Fator mensal da taxa de administração }=\frac{0,2}{60} \\
\text { Fator mensal de taxa de administração }=0,003333333
\end{gathered}
$$

Em seguida, calcula-se o valor da taxa de administração mensal: 
Taxa de administração mensal $=$ Valor do bem $\times$ Fator mensal da taxa de administração

Taxa de administração mensal $=50.000,00 \times 0,003333333$

Taxa de administração mensal $=R \$ 166,67$

2.4.3. Cálculo do valor da entrada mensal para o fundo de reserva

Inicia-se o cálculo com a identificação do fator mensal destinado ao fundo de reserva, conforme fórmula abaixo:

$$
\begin{gathered}
\text { Fator mensal de fundo de reserva }=\frac{\text { Fundo de reserva total }}{\text { Prazo de duração }} \\
\text { Fator mensal de fundo de reserva }=\frac{0,02}{60}
\end{gathered}
$$

Fator mensal de fundo de reserva $=0,000333333$

Em seguida, calcula-se o valor da entrada mensal para o fundo de reserva:

Entrada para o fundo de reserva $=$ Valor do bem $\times$ Fator mensal de fundo de reserva Entrada para o fundo de reserva $=50.000,00 \times 0,000333333$

Entrada para o fundo de reserva $=R \$ 16,67$

\subsubsection{Cálculo do valor mensal de desembolso do consorciado}

O valor mensal a ser desembolsado por cada consorciado é a soma da entrada mensal para o fundo comum, do valor mensal de taxa de administração e da entrada mensal para o fundo de reserva:

Entrada Fundo Comum + Taxa de administração mensal + Entrada fundo de reserva

$$
\begin{gathered}
\text { Desembolso }=833,34+166,67+16,67 \\
\text { Desembolso }=R \$ 1.016,68
\end{gathered}
$$


Considerando os valores adotados no exemplo e a necessidade de contemplações mensais, para que o consórcio tenha viabilidade econômico-financeira é preciso de, no mínimo, sessenta e um consorciados no grupo, que gerarão um fundo comum de $\mathrm{R} \$ 50.833,74(=\mathrm{R} \$ 833,34 * 61)$ a cada mês ${ }^{171}$.

Após esta visão geral da mecânica do consórcio é preciso uma compreensão um pouco mais detalhada da participação do consorciado no grupo, a realização das assembleias gerais, as regras de contemplação por sorteio ou por lance, utilização do crédito, cessão da cota e extinção do grupo de consórcio.

\subsection{Assembleias gerais do grupo}

Uma vez iniciado o funcionamento do grupo de consórcio, serão realizadas periodicamente assembleias gerais (por isso, diz-se que a assembleia geral neste caso reúne-se ordinariamente) para apreciar as contas da administradora e promover as contemplações dos participantes (art. 18 da Lei n. ${ }^{\circ} 11.795 / 08^{172}$ ). Os consorciados também podem reunir-se extraordinariamente em assembleia geral convocada pela administradora por meio de carta enviada com oito dias úteis de antecedência a todos os consorciados com aviso de recebimento (AR), telegrama ou mensagem eletrônica, por iniciativa própria ou por solicitação de trinta por cento dos consorciados, para apreciar e deliberar sobre qualquer assunto que não seja objeto da assembleia geral ordinária (art. 19 da Lei n. ${ }^{\circ}$ 11.795/08 ${ }^{173}$; art. 37 da Circular n. ${ }^{\circ} 3.432 / 09^{174}$ ).

171 A análise de viabilidade feita pela administradora é muito mais ampla do que a realizada no texto, pois deve levar em conta a possibilidade de pagamento de cada consorciado, estimativa de inadimplemento, estimativa de valorização do bem, dentre outros fatores. Ademais, como no exemplo acima o montante do fundo comum em cada mês fica muito próximo do valor do bem, isso dificultaria, para não dizer impediria, que os consorciados dessem seus lances nas assembleias gerais ordinárias do grupo.

172 "Art. 18. A assembléia geral ordinária será realizada na periodicidade prevista no contrato de participação em grupo de consórcio, por adesão, e destina-se a apreciação de contas prestadas pela administradora e a realização de contemplações".

173 “Art. 19. A assembléia geral extraordinária será convocada pela administradora, por iniciativa própria ou por solicitação de $30 \%$ (trinta por cento) dos consorciados ativos do grupo, para deliberar sobre quaisquer outros assuntos que não os afetos à assembléia geral ordinária”.

“Art. 37. A convocação da assembléia geral extraordinária deve ser feita mediante envio a todos os participantes do grupo de carta, com Aviso de Recebimento (AR), telegrama ou correspondência eletrônica, com até oito dias úteis de antecedência da sua realização, devendo dela constar, obrigatoriamente, informações relativas ao dia, hora e local em que será realizada a assembléia, bem como os assuntos a serem deliberados. 
As assembleias gerais serão instaladas com a presença de qualquer número de consorciados, pessoalmente ou por meio de representante com poderes especiais, específicos e expressos, ou cujo voto escrito foi recebido pela administradora no dia útil anterior à realização da assembleia geral (art. 38 da Circular n. ${ }^{\circ} 3.432 / 09^{175}$ ). Deliberará a assembleia geral por maioria simples de votos, cabendo um voto a cada cota de consorciado ativo, assim considerado o consorciado que mantém vínculo obrigacional com o grupo, excetuado o participante inadimplente não contemplado e o excluído (art. 20 e art. 21 da Lei n. ${ }^{\circ} 11.795 / 08^{176}$ ).

\subsection{Diferenças na entrada periódica do consorciado}

Importa notar que o sistema de preço de ponderado demanda a atualização do valor do bem ou do serviço na data da assembleia geral ordinária. Normalmente a sociedade administradora de grupos de consórcio envia aos consorciados um aviso de cobrança com o cálculo do valor total da entrada do consorciado acompanhado de uma ficha de compensação bancária, com vencimento antes da data da assembleia geral ordinária.

Parágrafo único. O prazo de que trata o caput será contado incluindo-se o dia da realização da assembléia e excluindo-se o dia da expedição da carta, telegrama ou correspondência eletrônica".

175 "Art. 38. Nas assembléias gerais:

I - podem votar os participantes em dia com o pagamento das prestações, seus representantes legais ou procuradores devidamente constituídos;

II - que se instalarão com qualquer número de consorciados do grupo, representantes legais ou procuradores devidamente constituídos, as deliberações serão tomadas por maioria simples dos votos dos presentes, não se computando os votos em branco.

$\S 1^{\circ}$ Para efeito do disposto no inciso II, consideram-se presentes os consorciados que, atendendo as condições de que trata o inciso I, enviarem seus votos por carta, com AR, telegrama ou correspondência eletrônica.

$\S 2^{\circ}$ Os votos enviados na forma do $\S 1^{\circ}$ serão considerados válidos, desde que recebidos pela administradora até o último dia útil que anteceder o dia da realização da assembléia geral”.

176 "Art. 20. A cada cota de consorciado ativo corresponderá um voto nas deliberações das assembléias gerais ordinárias e extraordinárias, que serão tomadas por maioria simples.

$\S 1^{\circ}$ A representação do ausente pela administradora na assembléia geral ordinária dar-se-á com a outorga de poderes, desde que prevista no contrato de participação em grupo de consórcio, por adesão.

$\S 2^{\underline{o}}$ A representação de ausentes nas assembléias gerais extraordinárias dar-se-á com a outorga de poderes específicos, inclusive à administradora, constando obrigatoriamente informações relativas ao dia, hora e local e assuntos a serem deliberados.

$\S 3^{\text {o }}$ Somente o consorciado ativo não contemplado participará da tomada de decisões em assembléia geral extraordinária convocada para deliberar sobre:

I - suspensão ou retirada de produção do bem ou extinção do serviço objeto do contrato;

II - extinção do índice de atualização do valor do crédito e das parcelas, indicado no contrato;

III - encerramento antecipado do grupo;

IV - assuntos de seus interesses exclusivos.

Art. 21. Para os fins do disposto nos arts. 19 e 20, é consorciado ativo aquele que mantém vínculo obrigacional com o grupo, excetuado o participante inadimplente não contemplado e o excluído, conforme definição do art. 29". 
Entretanto, como o valor do bem ou do serviço deve ser atualizado na data da assembleia, podem ocorrer diferenças entre o montante efetivamente pago pelo consorciado e o valor dos bens ou do serviço objeto do consórcio. Eventuais diferenças no valor da entrada do consorciado, tanto a menor ou maior, dependendo da valorização ou desvalorização do bem ou serviço no período (art. 17 da Circular n. ${ }^{\circ} 3.432 / 09^{177}$ ), devendo-se acrescentar ou descontar as diferenças até a segunda entrada que vencer após a apuração da diferença (art. 19 da Circular n. ${ }^{\text {3 } 3.432 / 09^{178}}$ ).

\subsection{Inadimplemento do consorciado}

Em caso de inadimplemento da entrada, o consorciado deverá pagar a multa pecuniária e os juros moratórios previstos no contrato de participação em grupo de consórcio, que serão rateados entre o grupo de consórcio e administradora na proporção fixada no contrato, limitado a cinquenta por cento para o grupo de consórcio (art. 28 da Lei n. $\left.{ }^{\circ} 11.795 / 08^{179}\right)$. Além dos juros moratórios e da multa, em caso do não pagamento de duas entradas, consecutivas ou alternadas, o consorciado não contemplado poderá ser excluído do grupo, conforme cláusula contratual nesse sentido. Pelo princípio da boa-fé objetiva $^{180}$, a exclusão somente poderá ocorrer após a interpelação judicial ou extrajudicial

177 “Art. 17. São diferenças de prestação:

I - as importâncias recolhidas a menor ou a maior em relação ao preço do bem, conjunto de bens, serviço ou conjunto de serviços referenciado no contrato, vigente na data da realização da respectiva assembléia geral ordinária;

II - as verificadas no saldo do fundo comum que passar de uma assembléia para outra, decorrentes de alteração no preço do bem, conjunto de bens, serviço ou conjunto de serviços referenciado no contrato, ocorridas no mesmo período, na forma do disposto no art. 18".

178 "Art. 19. O valor relativo à diferença de prestação deve ser cobrado ou compensado até a segunda prestação imediatamente seguinte à data da sua verificação".

“Art. 28. O valor da multa e de juros moratórios a cargo do consorciado, se previstos no contrato de participação em grupo de consórcio, por adesão, será destinado ao grupo e à administradora, não podendo o contrato estipular para o grupo percentual inferior a $50 \%$ (cinqüienta por cento)".

180 De acordo com o art. 9:301 do The Principles of European Contract Law, um modelo padrão de princípios contratuais preparados por acadêmicos e profissionais com objetivo de integração nas negociações entre partes localizadas em diferentes países da União Europeia, uma parte contratual somente pode exercer seu poder formativo de resolução ou de resilição da relação contratual se for verificado (1) inadimplemento substancial pelo devedor; ou (2) se o inadimplemento não for substancial, vencer o prazo adicional razoável conferido pelo credor em interpelação escrita e formal para purgação da mora. As hipóteses de inadimplemento substancial são arroladas no art. 8:103 e estão relacionadas, em essência, com frustração da finalidade do contrato pelo inadimplemento ou a quebra brutal de confiança no cumprimento das obrigações pelo devedor. A verdade é que o inadimplemento de duas entradas em uma relação contratual de vários meses, não pode ser considerado substancial nos termos expostos acima. Desse modo, somente pode ser admitido o exercício do poder formativo extintivo da relação jurídica do grupo de consórcio após o envio de interpelação fixando um prazo adicional razoável para pagamento e informação clara e inequívoca de que o não cumprimento após o prazo adicional acarretará a exclusão do consorciado do grupo de consórcio. 
do consorciado, por meio da qual lhe é conferido um prazo para realização do pagamento das entradas em atraso, acrescidas dos encargos moratórios, sob pena de exclusão do grupo $^{181}$. Se já foi contemplado e não utilizou o crédito de sua titularidade, o contrato poderá prever a extinção do crédito por decadência. Em caso de utilização do crédito pelo consorciado contemplado, a administradora deverá excutir a garantia imediatamente após o atraso de mais de uma entrada por parte do consorciado contemplado (art. 21 da Circular n. $\left.3.432 / 09^{182}\right)$.

A par dos efeitos patrimoniais decorrentes do inadimplemento, o consorciado em mora não poderá votar nas deliberações das assembleias gerais e não poderá ser

$181 \quad$ Neste ponto cabe distinguir figuras que normalmente são confundidas pela doutrina e jurisprudência. Avisar é um fenômeno fático de levar determinado enunciado de fato (= mensagem) ao conhecimento de terceiro. Avisar é ato social de cientificação de uma mensagem, mas não entra no mundo jurídico. Quem avisa informa a um ou alguns membros do grupo social, sem maiores relevâncias jurídicas. O aviso é realizado por deveres morais, familiares, religiosos, afetivos, mas nunca jurídicos. Como diz o provérbio popular: "Quem avisa amigo é". O indivíduo que avisa é agente social; figura em relações sociais e atua dentro da ordem social. Atuar socialmente não é o mesmo que atuar juridicamente. Comunicar é mais do que avisar. Quem comunica realiza ato jurídico stricto sensu enunciativo, exteriorizando uma representação do mundo exterior (= conhecimento) ou um sentimento. Quem comunica simplesmente enuncia um conhecimento ou um sentimento. Notificar, por sua vez, já é um grau acima da comunicação. A notificação é um ato jurídico stricto sensu comunicativo. É o ato de dar ciência a outrem a respeito de uma decisão, de um querer, de uma vontade. Sua função é "dar ciência a alguém, figurante de uma relação jurídica, do querer de quem faz a comunicação" (M. BERNARDES DE MELlo, Teoria do Fato Jurídico - Plano da Existência, 18. ${ }^{a}$ ed., São Paulo, Saraiva, 2012, p. 200). Na notificação, "não se espera que a conduta do que as recebe seja essa, ou aquela, e que, conforme seja, tenha tal ou tal efeito a manifestação de vontade: comunica-se que tal é a vontade do que comunica" (F. C. PONTES DE MIRANDA, Tratado de Direito Privado, t. II, $4^{\mathrm{a}}$ ed., São Paulo, Revista dos Tribunais, 1983, § 231, n. 1, p. 453). A interpelação, por fim, é o mais solene dos atos. Consiste em um ato jurídico stricto sensu reclamativo ou provocativo. Clama-se do interpelado uma ação ou omissão. Provoca-o a tomar uma atitude. E o interpelado "ou atende ao que dele se reclama, ou sobre o seu desatendimento, como suporte fático, incide regra jurídica, que o ponha no mundo jurídico, produzindo, então, fato jurídico, com os respectivos efeitos jurídicos" (F. C. PONTES DE MIRANDA, Tratado de Direito Privado cit., t. II, § 230, (a), n. 1, p. 452). O credor interpela o devedor para que cumpra a prestação. Caso este não o faça, incide a norma jurídica do inadimplemento absoluto ou relativo, produzindo-se os efeitos respectivos. A mora, por exemplo, é efeito do inadimplemento e não da interpelação. Em muitas situações, contudo, só haverá inadimplemento após a interpelação. Conforme explica F. C. PONTES DE MIRANDA (Tratado de Direito Privado cit., t. II, § 235, p. 464): “A interpelação é o ato pelo qual o credor exige ao devedor a prestação. O interpelante quer exercer o seu direito; mas precisa manifestar (ou lhe parece aconselhável manifestar) a vontade interpelativa. Há manifestação de vontade; por ela o credor comunica que deseja fazer efetivo (= exercer) o seu direito". Resta claro que a exigência de solenidades que envolvem estas figuras é gradativa. A comunicação praticamente não depende de uma forma ou de uma solenidade. A notificação, entretanto, é mais solene, porque se exterioriza uma decisão juridicamente relevante, ao passo que a comunicação exterioriza uma representação sobre o mundo exterior ou sobre sentimentos. Já a interpelação, por clamar uma conduta, positiva ou negativa, de outrem, reveste-se de grandes solenidades. A imposição de solenidade na interpelação é necessária para proteção dos sujeitos envolvidos, visto que a observância ou não da conduta reclamada compõe suporte fático de normas jurídicas.

182 "Art. 21. A administradora deve adotar, de imediato, os procedimentos legais necessários à execução das garantias se o consorciado contemplado atrasar o pagamento de mais de uma prestação". 
contemplado, seja por sorteio ou por lance (Lei n. ${ }^{\circ} 11.795 / 08$, art. $19^{183}$, art. 20, caput $^{184}$,

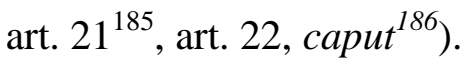

\subsection{Cobranças adicionais}

Além da entrada para o fundo comum e para o fundo de reserva, o pagamento da taxa de administração e do prêmio para o seguro de vida em grupo, dependendo das circunstâncias e vicissitudes da relação, o contrato de participação em grupo de consórcio pode prever o pagamento pelo consorciado dos seguintes valores adicionais: (1) das diferenças das entradas; (2) despesas com registro dos instrumentos contratuais de garantia; (3) despesas com registro dos instrumentos contratuais de cessão ou transferência; (4) taxas de cadastro, taxas de transferência e tarifas bancárias; (5) juros de mora; (6) multa pecuniária; (7) honorários de advogado e despesas judiciais; (8) reajuste de saldo de caixa; (9) diferenças de complemento no preço do bem ou no valor de retribuição do serviço; (10) taxas para emissão de segunda via de documentos; e (11) eventuais despesas para a utilização do crédito em praça diferente ${ }^{187}$.

\subsection{Contemplação}

Consoante mencionado acima, a contemplação consiste na atribuição de crédito a um consorciado, por sorteio ou lance, para a utilização na compra do bem ou

\footnotetext{
183 “Art. 19. A assembléia geral extraordinária será convocada pela administradora, por iniciativa própria ou por solicitação de 30\% (trinta por cento) dos consorciados ativos do grupo, para deliberar sobre quaisquer outros assuntos que não os afetos à assembléia geral ordinária”.

"Art. 20. A cada cota de consorciado ativo corresponderá um voto nas deliberações das assembléias gerais ordinárias e extraordinárias, que serão tomadas por maioria simples".

185 "Art. 21. Para os fins do disposto nos arts. 19 e 20, é consorciado ativo aquele que mantém vínculo obrigacional com o grupo, excetuado o participante inadimplente não contemplado e o excluído, conforme definição do art. 29.".

186 "Art. 22. A contemplação é a atribuição ao consorciado do crédito para a aquisição de bem ou serviço, bem como para a restituição das parcelas pagas, no caso dos consorciados excluídos, nos termos do $\underset{187}{\operatorname{art} .30 "}$.

Cf. A. M. DE Sousa FigueIREDO, ABC do Consórcio cit., p. 46.
} 
contraprestação pelo serviço, ou a atribuição de crédito à restituição das entradas realizadas ao consorciado excluído (art. 22 da Lei n. ${ }^{\circ} 11.795 / 08^{188}$ ).

Os sorteios ocorrem nas assembleias gerais ordinárias do grupo, nas quais todos os consorciados adimplentes e os participantes excluídos concorrem em igualdade de condições, mas nem a Lei n. ${ }^{\circ} 11.795 / 08$ nem a regulamentação do Banco Central disciplinam a forma como acontece o sorteio, devendo o mecanismo concreto adotado constar do contrato de participação no grupo de consórcio ou no regulamento do grupo de consórcio. Independentemente da forma de sorteio adotada (urnas, papéis, programas de computador, e outros), o mais importante é assegurar a idoneidade do sorteio, garantindo a isonomia entre os participantes.

Uma vez realizada a contemplação pelo sorteio, ou se ela não for realizada por insuficiência de fundos, poderá ocorrer a contemplação por lance, isto é, os consorciados ativos que desejarem oferecem determinada quantia a título de adiantamento das entradas e da taxa de administração para serem contemplados e, de acordo com as cláusulas previstas no contrato de participação no grupo de consórcio, o consorciado que deu o maior lance é contemplado. Pode o contrato de participação no grupo prever a modalidade de lance embutido, por meio da qual o valor do lance será descontado do crédito a ser atribuído na assembleia geral ordinária (art. 9. ${ }^{\circ}$ da Circular n. ${ }^{\circ} 3.432 / 09^{189}$ ).

188 “Art. 22. A contemplação é a atribuição ao consorciado do crédito para a aquisição de bem ou serviço, bem como para a restituição das parcelas pagas, no caso dos consorciados excluídos, nos termos do art. 30 .

$\S 1^{\circ}$ A contemplação ocorre por meio de sorteio ou de lance, na forma prevista no contrato de participação em grupo de consórcio, por adesão.

$\S 2^{\circ}$ Somente concorrerá à contemplação o consorciado ativo, de que trata o art. 21, e os excluídos, para efeito de restituição dos valores pagos, na forma do art. 30.

$\S 3^{\circ} \mathrm{O}$ contemplado poderá destinar o crédito para a quitação total de financiamento de sua titularidade, sujeita à prévia anuência da administradora e ao atendimento de condições estabelecidas no contrato de consórcio de participação em grupo".

189 "Art. $9^{\circ}$ É admitida a contemplação em grupos de consórcio por meio de lance embutido, assim considerada a oferta de recursos, para fins de contemplação, mediante utilização de parte do valor do crédito previsto para distribuição na respectiva assembléia.

$\S 1^{\circ} \mathrm{O}$ valor do lance vencedor deve:

I - ser integralmente deduzido do crédito previsto para distribuição na assembléia de contemplação, disponibilizados ao consorciado recursos correspondentes ao valor da diferença daí resultante;

II - destinar-se ao abatimento de prestações vincendas, compostas por parcelas do fundo comum e dos encargos vinculados previstos no contrato, de que são exemplos a taxa de administração e o fundo de reserva;

III - ser contabilizado em conta específica.

$\S 2^{\circ}$ No oferecimento de lance com recursos do Fundo de Garantia do Tempo de Serviço (FGTS) devem ser observadas as disposições baixadas pelo Conselho Curador do FGTS e pela Caixa Econômica Federal, na qualidade de agente operador do FGTS". 
No caso de grupos de consórcio heterogêneos, se o contrato de participação no grupo admitir lance em percentual do valor do bem ou da retribuição do serviço, o lance vencedor será aquele que corresponder a maior percentual em relação ao valor do crédito do consorciado, mesmo que inferior em valor monetário aos lances de outros consorciados.

\subsection{Utilização do crédito pelo consorciado}

O consorciado contemplado passa a ser titular de crédito à transferência dos recursos monetários em valor correspondente ao crédito ao fornecedor do bem ou do serviço de sua escolha. Além da aplicação dos recursos para aquisição do bem ou obtenção do serviço, o consorciado também poderá utilizar o crédito, desde que previsto no contrato de participação no grupo de consórcio, para: (1) optar por construção ou reforma de bem imóvel, desde que em município em que a administradora opere ou, se autorizado por essa, em município diverso, se o contrato estiver referenciado em bem imóvel; (2) realizar o adimplemento total de financiamento, de sua titularidade, nas condições previstas no contrato, de bens e serviços possíveis de serem adquiridos por meio do crédito obtido; e (3) receber o valor do crédito em espécie, mediante cumprimento integral de seus deveres para com o grupo, caso ainda não tenha utilizado o respectivo crédito decorridos cento e oitenta dias após a contemplação (art. 5. ${ }^{\circ}$, XIII da Circular n. ${ }^{\circ} 3.432 / 09^{190}$ ).

Visando proteger a viabilidade do grupo, a utilização do crédito pelo consorciado contemplado antes do pagamento total depende do oferecimento de garantia em favor do grupo, que consiste, em regra, no próprio bem adquirido com os recursos do grupo (art. 14

$190 \quad$ “Art. 5. ${ }^{\circ}$...

XIII - a faculdade de o consorciado contemplado poder:

a) adquirir, em fornecedor, vendedor ou prestador de serviço que melhor lhe convier:

1. veículo automotor, aeronave, embarcação, máquinas e equipamentos, se o contrato estiver referenciado em qualquer bem mencionado neste item;

2. qualquer bem móvel ou conjunto de bens móveis, novos, excetuados os referidos no item 1 , se o contrato estiver referenciado em bem móvel ou conjunto de bens móveis não mencionados naquele item;

3. qualquer bem imóvel, construído ou na planta, inclusive terreno, ou ainda optar por construção ou reforma, desde que em município em que a administradora opere ou, se autorizado por essa, em município diverso, se o contrato estiver referenciado em bem imóvel;

4. serviço, se o contrato estiver referenciado em serviço;

b) adquirir o bem imóvel vinculado a empreendimento imobiliário, na forma prevista no contrato, se assim estiver referenciado;

c) realizar a quitação total de financiamento, de sua titularidade, nas condições previstas no contrato, de bens e serviços possíveis de serem adquiridos por meio do crédito obtido;

d) receber o valor do crédito em espécie, mediante quitação de suas obrigações para com o grupo, caso ainda não tenha utilizado o respectivo crédito decorridos 180 dias após a contemplação”. 
da Lei n. ${ }^{\circ} 11.795 / 08^{191}$ ). É dever da sociedade administradora do grupo de consórcio excutir a garantia imediatamente após o atraso de mais de uma entrada por parte do consorciado contemplado (art. 21 da Circular n. ${ }^{\text {3 } 3.432 / 09^{192}}$ ).

\subsection{Exclusão do grupo e desistência do consorciado}

A exclusão de determinado participante extingue automaticamente o status de consorciado, passando a ser tratado como participante excluído e tornando-se titular de crédito à restituição dos valores contribuídos para a formação do fundo comum, mas a pretensão à restituição somente nascerá se o participante excluído for contemplado em assembleia geral ordinária ou, caso não seja contemplado em nenhuma assembleia, após sessenta dias da realização da última assembleia de contemplação (Lei n. ${ }^{\circ}$ 11.795/08, art. $20^{193}$, art. $30^{194}$, art. $31^{195}$ ).

191 “Art. 14. No contrato de participação em grupo de consórcio, por adesão, devem estar previstas, de forma clara, as garantias que serão exigidas do consorciado para utilizar o crédito. consórcio

$\S 1^{\circ}$ As garantias iniciais em favor do grupo devem recair sobre o bem adquirido por meio do

$\S 2^{\circ}$ No caso de consórcio de bem imóvel, é facultado à administradora aceitar em garantia outro imóvel de valor suficiente para assegurar o cumprimento das obrigações pecuniárias do contemplado em face do grupo.

$\S 3^{\mathrm{o}}$ Admitem-se garantias reais ou pessoais, sem vinculação ao bem referenciado, no caso de consórcio de serviço de qualquer natureza, ou quando, na data de utilização do crédito, o bem estiver sob produção, incorporação ou situação análoga definida pelo Banco Central do Brasil. vincendas.

$\S 4^{\mathrm{O}} \mathrm{A}$ administradora pode exigir garantias complementares proporcionais ao valor das prestações

$\S 5^{\circ}$ A administradora deve indenizar o grupo na ocorrência de eventuais prejuízos decorrentes:

I - de aprovação de garantias insuficientes, inclusive no caso de substituição de garantias dadas na forma dos $\S \S 1^{\circ}, 2^{\underline{o}}$ e $3^{\underline{o}}$;

II - de liberação de garantias enquanto o consorciado não tiver quitado sua participação no grupo.

$\S 6^{0}$ Para os fins do disposto neste artigo, o oferecedor de garantia por meio de alienação fiduciária de imóvel ficará responsável pelo pagamento integral das obrigações pecuniárias estabelecidas no contrato de participação em grupo de consórcio, por adesão, inclusive da parte que remanescer após a execução dessa garantia.

$\S 7^{0}$ A anotação da alienação fiduciária de veículo automotor ofertado em garantia ao grupo de consórcio no certificado de registro a que se refere o Código de Trânsito Brasileiro, Lei n ${ }^{\circ} 9.503$, de 23 de setembro de 1997, produz efeitos probatórios contra terceiros, dispensado qualquer outro registro público".

192 "Art. 21. A administradora deve adotar, de imediato, os procedimentos legais necessários à execução das garantias se o consorciado contemplado atrasar o pagamento de mais de uma prestação".

193 "Art. 22. A contemplação é a atribuição ao consorciado do crédito para a aquisição de bem ou serviço, bem como para a restituição das parcelas pagas, no caso dos consorciados excluídos, nos termos do art. 30".

194 “Art. 30. O consorciado excluído não contemplado terá direito à restituição da importância paga ao fundo comum do grupo, cujo valor deve ser calculado com base no percentual amortizado do valor do bem ou serviço vigente na data da assembléia de contemplação, acrescido dos rendimentos da aplicação financeira a que estão sujeitos os recursos dos consorciados enquanto não utilizados pelo participante". 
À primeira vista, pode causar estranheza o participante excluído do grupo por inadimplemento participar em igualdade de condições com os consorciados ativos, mas a solução legal é razoável e visa equilibrar os interesses do grupo com os interesses do participante excluído. Como regra geral, a resolução ou resilição ${ }^{196}$ da relação contratual em relação ao participante excluído exigiria a imediata liquidação do patrimônio em comum para a restituição dos aportes realizados pelo excluído. Para se evitar os efeitos perversos desse princípio, é preciso uma norma jurídica que atribua um momento para o cumprimento da prestação de restituição. O legislador optou por um regime de justiça, na medida em que sujeitou o pagamento dos valores a serem restituídos ao sorteio em assembleia geral de contemplação.

Grande discussão surge com relação ao momento da restituição do consorciado desistente, começando com a proposição jurídica enunciada na Portaria MF n. ${ }^{\circ}$ 190/1990 que determinava a devolução ao consorciado desistente dos valores pagos por ele para a formação do fundo comum sem juros e atualização monetária no prazo de trinta dias após o encerramento do grupo. A Súmula 35 do Superior Tribunal de Justiça expressamente afastou a norma jurídica do Ministério da Fazenda e reconheceu a incidência de "correção monetária sobre as prestações pagas, quando de sua restituição, em virtude da retirada ou exclusão do participante de plano de consórcio".

O debate sobre o assunto não passou despercebido pelo legislador, que inclui no Código de Defesa do Consumidor o $§ 2 .^{\circ}$ do art. 53, com o objetivo de disciplinar os caso de resolução ou resilição da relação contratual no âmbito do sistema de consórcios, determinando que "a compensação ou a restituição das parcelas quitadas, [...] terá descontada, além da vantagem econômica auferida com a fruição, os prejuízos que o desistente ou inadimplente causar ao grupo". Ainda assim, faltava a fixação do momento em que a restituição dos valores aportados para o fundo comum e para o fundo de reserva deveria ser realizada, visto que os consorciados desistentes desejam a devolução imediata e

195 “Art. 31. Dentro de 60 (sessenta) dias, contados da data da realização da última assembléia de contemplação do grupo de consórcio, a administradora deverá comunicar:

I - aos consorciados que não tenham utilizado os respectivos créditos, que os mesmos estão à disposição para recebimento em espécie".

196 Não há unanimidade doutrina a respeito da distinção entre resolução, resilição e denúncia, com cada autor adotando uma posição particular do fenômeno da extinção das relações jurídicas. Adota-se a proposta formulada por F. C. PONTES DE MIRANDA que enxerga a resolução como um fenômeno eficacial de extinção ex tunc de relação jurídica por tempo determinado (= com prazo), enquanto a resilição é a desconstituição da relação jurídica aprazada com efeitos ex nunc. Consoante tal visão, a denúncia é negócio jurídico unilateral com eficácia modificativa por meio do qual o denunciante coloca um termo final a uma relação jurídica sem prazo e, apesar de atuar no plano da eficácia como as demais figuras, não se confunde quer com a resolução

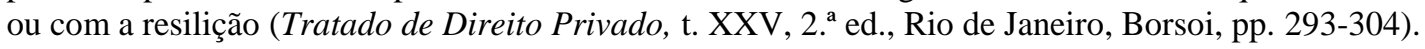


as administradoras de grupos de consórcios sustentam a necessidade de se garantir a viabilidade do grupo, protraindo-se a restituição após a última contemplação dos consorciados ativos. Ao assumir o papel de normatizador do sistema de consórcios no início da década de 1990, o Banco Central definiu o prazo de sessenta dias após a realização da última assembleia geral de contemplação para a devolução dos aportes ao fundo comum e ao fundo de reserva para os participantes excluídos e desistentes. Em pouco tempo, muitos consorciados questionaram a abusividade da cláusula contratual em juízo e a doutrina discutiu longamente a respeito do momento correto para a restituição dos valores $^{197}$.

Procurando dar um ponto final na discussão, o projeto de lei que veio a se tornar a Lei n. ${ }^{\circ}$ 11.795/08 aprovado pelo Congresso Nacional equiparava o desistente com o participante excluído, sujeitando-o ao sorteio nas assembleias gerais de contemplação. Tal equiparação, contudo, foi vetada pelo Presidente da República, com fundamento no referido artigo 53 do Código de Defesa do Consumidor e no princípio da boa-fé, que demandariam a devolução imediata dos valores pagos pelo consorciado desistente:

\begin{abstract}
"Nesse contexto, os dispositivos citados afrontam diretamente o art. 51, IV, c/c o art. 51, $\$ 1 .^{\circ}$, III, do CDC, que estabelecem regra geral proibitória da utilização de cláusula abusiva nos contratos de consumo. Com efeito, embora o consumidor deva arcar com os prejuízos que trouxer ao grupo de consorciados, conforme $\S$ 2. ${ }^{\circ}$ do art. 53 do CDC, mantê-lo privado de receber os valores vertidos até o final do grupo ou até sua contemplação é absolutamente antijurídico e ofende o princípio da boa-fé, que deve prevalecer em qualquer relacão contratual.
\end{abstract}

Ademais, a inteligência do Código de Defesa do Consumidor é de coibir a quebra de equivalência contratual e considerar abusiva as cláusulas que colocam o consumidor em 'desvantagem exagerada', tal como ocorre no caso presente. A devolução das prestações deve ser imediata, sob pena de impor ao consumidor uma longa e injusta espera" (reforços gráficos não originais).

Como os vetos do Presidente da República simplesmente fizeram com que a Lei n. ${ }^{\circ}$ 11.795/08 nada tratasse sobre o assunto, mantendo as incertezas entre todos os envolvidos no setor, o Banco Central procurou restabelecer a linha condutora do projeto de lei original e equiparou o consorciado desistente ao participante excluído no art. $2 .^{\circ}$ da Circular n. ${ }^{\circ}$ 3.432/09: 197 Para uma súmula das diversas posições a respeito, ver D. ORFALE GIACOMINI, A Devolução cit., pp.
148 e ss. 


\begin{abstract}
“Art. $2^{\circ}$ Considera-se consorciado excluído o participante que:
I - manifeste, por escrito, intenção de não permanecer no grupo;

II - deixe de cumprir as obrigações financeiras previstas, nos termos do contrato.

Parágrafo único. É vedada a exclusão de consorciado contemplado”.
\end{abstract}

Em princípio, a equiparação do desistente com o participante excluído faz com que ambos possam participar dos sorteios realizados nas assembleias gerais e, caso haja a contemplação, podem exigir a restituição dos valores no prazo de três dias úteis, da mesma forma como a colocação à disposição do crédito ao consorciado ativo contemplado. Todavia, F. FERNANDES RIBEIRO MAIA critica com veemência a estratégia regulatória adotada pelo Banco Central, pois, em seu modo de ver, ao mesmo tempo em que o Circular n. ${ }^{\circ} 3.432 / 2009$ equipara o desistente ao participante excluído, o prazo de três dias úteis é apenas aplicável ao crédito dos consorciados ativos, enquanto o pagamento do crédito à restituição dos participantes excluídos deverá ser previsto no contrato de participação no grupo de consórcio. Então, as sociedades administradoras de grupos de consórcio continuarão a incluir a cláusula de restituição após o encerramento do grupo, e o Poder Judiciário deverá decidir pela abusividade ou não da cláusula ${ }^{198}$.

Com relação à discussão da abusividade da cláusula de restituição dos valores após o encerramento do plano, o Superior Tribunal de Justiça, em sede de recursos repetitivos, definiu, pelo mesmo para a legislação anterior à Lei n. ${ }^{\circ}$ 11.795/08, que a devolução com juros e correção monetária após trinta dias do encerramento do grupo não é considerada abusiva:

"RECURSO ESPECIAL REPETITIVO. JULGAMENTO NOS MOLDES DO ART. 543-C DO CÓDIGO DE PROCESSO CIVIL. CONSÓRCIO. DESISTÊNCIA. DEVOLUÇÃO DAS PARCELAS PAGAS PELO CONSORCIADO. PRAZO. TRINTA DIAS APÓS O ENCERRAMENTO DO GRUPO.

1. Para efeitos do art. 543-C do Código de Processo Civil: é devida a restituição de valores vertidos por consorciado desistente ao grupo de consórcio, mas não de imediato, e sim em até trinta dias a contar do prazo previsto contratualmente para o encerramento do plano.

2. Recurso especial conhecido e parcialmente provido" ${ }^{\text {"199. }}$.

$198 \quad$ O Sistema de Consórcio Financeiro cit., pp. 66 e ss.

199 STJ, Recurso Especial Repetitivo n. ${ }^{\circ}$ 1.119.300 - RS, Rel. Min. Luis Felipe Salomão, julgado em 14 de abril de 2010, publicado no DJe de 27 de agosto de 2001. 
Apesar das ponderações de F. FERNANDES RIBEIRO MAIA acima mencionadas, tanto a lógica original da Lei n. ${ }^{\circ}$ 11.795/08 como da Circular n. ${ }^{\circ}$ 3.432/09 não é jogar o pagamento da devolução das parcelas pagas pelo participante excluído ou desistente no momento do encerramento do grupo de consórcio, e sim colocá-los em igualdade de situação com os demais consorciados, concorrendo ao sorteio nas assembleias de contemplação e devendo ter à disposição os recursos a serem restituídos no prazo de três dias úteis da realização da assembleia. Trata-se de uma solução mais justa e racional, procurando equilibrar de maneira salomônica os interesses do grupo de consórcio e do participante excluído. Conforme entendeu o Superior Tribunal de Justiça no acórdão supra, a não restituição imediata do participante desistente não é, por si, abusiva, embora possa vir a ser usada de maneira abusiva.

\subsection{Encerramento do grupo de consórcio}

Após a realização de todas as assembleias de contemplação previstas no calendário do grupo, com a contemplação de todos os consorciados e dos participantes excluídos, o grupo de consórcio deve ser encerrado. Como ato preliminar para o encerramento, a administradora deve, no prazo máximo de sessenta dias após a realização da última assembleia de contemplação, comunicar por escrito aos consorciados e participantes excluídos que estão à disposição os créditos não utilizados e os saldos do fundo comum e

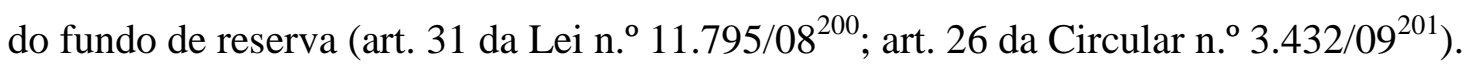

Passados pelo menos trinta dias da realização da comunicação aos consorciados e participantes excluídos, e dentro do prazo de cento e vinte dias da realização da última

200 “Art. 31. Dentro de 60 (sessenta) dias, contados da data da realização da última assembléia de contemplação do grupo de consórcio, a administradora deverá comunicar:

I - aos consorciados que não tenham utilizado os respectivos créditos, que os mesmos estão à disposição para recebimento em espécie".

201 “Art. 26. A comunicação de que trata o art. 31 da Lei no 11.795, de 2008, observado o prazo nele estabelecido, deve ser encaminhada também aos seguintes participantes contendo informações sobre:

I - aos participantes excluídos que não tenham utilizado ou resgatado os respectivos créditos, que os mesmos estão à disposição para recebimento em espécie;

II - aos consorciados ativos, que estão à disposição, para devolução em espécie, os saldos remanescentes no fundo comum e, se for o caso, no fundo de reserva, rateados proporcionalmente ao valor das respectivas prestações pagas.

$\S 1^{\circ}$ A comunicação mencionada no caput deve ser realizada por meio de carta com Aviso de Recebimento (AR), telegrama ou correspondência eletrônica com controle de recebimento, sendo obrigatória a manutenção de documentação comprobatória dos procedimentos adotados.

$\S 2^{\circ} \mathrm{O}$ encerramento de grupo e a existência de recursos à disposição dos consorciados e participantes excluídos devem ser divulgados no sítio eletrônico da administradora na internet.”. 
assembleia geral de contemplação, a sociedade administradora do grupo deverá prestar contas de sua gestão aos consorciados, tomar as providências finais para registro dos valores não procurados e declarar encerrado o grupo de consórcio (art. 32 da Lei n. ${ }^{\circ}$ $\left.11.795 / 08^{202}\right)$.

Esta seção procurou descrever sumariamente o funcionamento prático do consórcio, ressaltando a eleva complexidade nas relações dos consorciados entre si e do grupo de consórcio com a sociedade administradora de grupos de consórcio decorrentes do contrato de participação em grupo de consórcio, que assume um papel na disciplina e na estruturação do sistema de consórcios. Como primeiro passo para classificar e para qualificar o contrato de participação em grupo de consórcio, será preciso propor um método estrutural de análise, baseado na teoria do fato jurídico.

202 "Art. 32. O encerramento do grupo deve ocorrer no prazo máximo de 120 (cento e vinte) dias, contado da data da realização da última assembléia de contemplação do grupo de consórcio e desde que decorridos, no mínimo, 30 (trinta) dias da comunicação de que trata o art. 31, ocasião em que se deve proceder à definitiva prestação de contas do grupo, discriminando-se:

I - as disponibilidades remanescentes dos respectivos consorciados e participantes excluídos;

II - os valores pendentes de recebimento, objeto de cobrança judicial.

$\S 1^{\underline{0}}$ Os valores pendentes de recebimento, uma vez recuperados, devem ser rateados proporcionalmente entre os beneficiários, devendo a administradora, até 120 (cento e vinte) dias após o seu recebimento, comunicar-lhes que os respectivos saldos estão à disposição para devolução em espécie.

$\S 2^{\mathrm{o}}$ Prescreverá em 5 (cinco) anos a pretensão do consorciado ou do excluído contra o grupo ou a administradora, e destes contra aqueles, a contar da data referida no caput". 


\section{ANÁliSE ESTRUTURAL DOS FATOS JURÍDICOS: O PLANO DA EXISTÊNCIA, O PLANO DA VALIDADE E O PLANO DA EFICÁCIA}

O objetivo desta seção é apresentar a metodologia de análise do contrato de participação em grupo de consórcio a partir da divisão proposta por F. C. PONTES DE MirANDA $^{203}$ e retomada por A. JUnQueIRA DE AZEVEDO ${ }^{204}$, M. BERnARDES DE MELLO ${ }^{205}$ e A. Tomasetti JR. ${ }^{206}$ do mundo dos fatos jurídicos em três planos. Procura-se apontar quais correntes, teorias e concepções que explicam o fenômeno jurídico são adotadas neste estudo, de maneira a garantir um diálogo claro e conciso, sem ruídos de comunicação.

Deve ser ressaltado, antes de tudo, que a exposição a seguir é fruto de uma escolha filosófica, escolha esta que conduz a uma visão eminentemente idealista do mundo, separando o mundo real (= dos fatos) do mundo jurídico, que é um mundo de pensamento $(=\text { mundo ideal ou mundo eidético })^{207}$. Há concepções do Direito que seguem o materialismo filosófico, considerando como norma jurídica o momento da praxis, isto é, o momento da aplicação do Direito. Por serem escolhas filosóficas, prévias ao próprio pensamento científico, não podem ser classificadas como certas ou erradas, pois são modos diferentes de se enxergar o mundo e, como toda a forma de visão, encontram limites na sua capacidade visual $^{208}$.

Iniciar-se-á a exposição com base na teoria do fato jurídico e sua classificação, passando pela identificação dos planos da existência, da validade e da eficácia, dando-se especial ênfase às situações jurídicas multisubjetivas ou relação jurídica.

\footnotetext{
203 Cf. Tratado de direito privado, t. I, 2. ${ }^{\text {a }}$ ed., Rio de Janeiro, Borsoi, 1970, pp. 1-117.

204 Cf. Negócio Jurídico - Existência, Validade e Eficácia, São Paulo, Saraiva, 4. a ed., 2002, pp. $23-71$.

205 Cf. M. Bernardes de Mello, Teoria do Fato Jurídico - Plano da Existência, 18. a ed., São Paulo, Saraiva, 2012, pp. 33-140.

206 Cf. Teoria Geral do Direito Privado, mimeo, São Paulo, 2004.

207 Cf. A. Levi, Teoria Generale del Dirito, 2. ${ }^{\text {a }}$ ed., Padova, Cedan, 1967, p. 427 e ss., para quem o mundo jurídico é um mundo ideal composto por valores que só podem ser compreendidos a partir do exame dos fatos que concretizam os valores, pois, afinal, sem o fato, o valor é apenas uma virtualidade.

208 Explica F. C. PONTES DE MIRANDA que o conceito de fatos e o conceito de fatos jurídicos são modelos de análise do Direito: "Para uso nosso, fazemos modelos de fatos, inclusive de fatos jurídicos, para que o quadro jurídico descreva o mundo jurídico, engastando-o no mundo total. Daí os primeiros enunciados: (a) $O$ mundo jurídico está no conjunto a que se chama o mundo. (b) O mundo concorre com fatos seus para que se construa o mundo jurídico; porém esse seleciona e estabelece a causação jurídica, não necessariamente correspondente à causação dos fatos. (c) A juridicização é o processo peculiar ao direito; noutros termos: o direito adjetiva os fatos para que sejam jurídicos (= para que entrem no mundo jurídico)" (Tratado de Direito Privado cit., t. I, § 2. ${ }^{\text {o }}$ n. 1, p. 5-6).
} 


\subsection{Fato natural, fato social e fato jurídico}

O Direito é um fenômeno social que existe por causa da sociedade, dentro da sociedade e como parte da sociedade, com a função de ordenação da vida social, classificando, atribuindo e dispondo, e, portanto, concomitantemente conformado pelas necessidades da vida social ${ }^{209}$. A vida social, por sua vez, só existe dentro do mundo, e o mundo não é estático; é dotado de um dinamismo com grande fulgor, sendo modificado a cada instante. Mesmo o tempo é tão só mais uma dimensão das mudanças do mundo, sendo cada mudança um acontecimento ou um fato. Como o mundo está sempre em movimento, é um vir-a-ser, é possível afirmar que o mundo nada mais é do que um conjunto de fatos que aconteceram, acontecem e irão acontecer, ou nas palavras de F. C. PONTES DE MiRANDA: “O mundo mesmo, em que vemos acontecerem os fatos, é a soma de todos os fatos que ocorreram e o campo em que os fatos futuros se vão dar,210.

Adotando como critério sua relação com os seres-humanos, os fatos do mundo podem ser classificados como eventos e condutas $^{211}$. Os eventos são os fatos puramente naturais, não impulsionados pelo agir humano, ou, quando a atuação humana se faz presente, é atuação meramente biológica, muitas vezes até instintiva (ex. nascer, morrer, adoecer). As condutas, por sua vez, consistem nas atuações humanas que não decorram exclusivamente de natureza biológica, mas do caráter ímpar de ser humano com um ser apto a para tomar decisões e suportar as consequências dessas decisões, e admitem uma subclassificação, tendo em vista a presença de uma valoração prévia, visto que faz parte da natureza singular do homem uma atitude valorativa para com os estímulos do ambiente. Por outro lado, há condutas que carecem de um processo de valoração considerado relevante para fins da ordenação do comportamento, como os meros reflexos ou até fruto de um processo valorativo que não exterioriza o valor ou desvalor sobre o mundo.

O mundo jurídico está contido no mundo dos fatos, o Direito é em si mesmo um

\footnotetext{
209 G. RADBRUCH explica que o Direito é fenômeno da cultura, um fato cultural referenciado a valores, com a função de servir como uma ponte entre a realidade e valor. As normas jurídicas, então, não juízos de existência ou juízos de valor, mas juízos referenciados a valores, em especial à ideia de justiça (Filosofia do

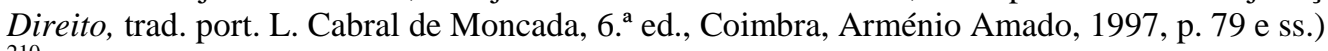

$210 \quad$ Tratado de Direito Privado cit., t. I, p. 3.

211 Cf. M. Bernardes de Mello, Teoria do Fato Jurídico - Plano da Existência cit., p. 38, citando classificação proposta por LOURIVAL VILANOVA.
} 
fato cultural ${ }^{212}$, e é composto por fatos que gozam, numa análise valorativa de quem é titular do poder de tomar decisões normativas ${ }^{213}$, de relevância no relacionamento intersubjetivo das pessoas. Mesmo com a proliferação de normas jurídicas dos dias atuais, nos quais muitas áreas da vida são incluídas no mundo jurídico, é possível identificar uma grande (para não dizer gigantesca) gama de fatos que por não estarem no controle do ser humano, por não afetarem interesses ou por simplesmente não resultarem em vantagem ou custos são consideradas como juridicamente irrelevantes e não integram o mundo jurídico $^{214}$. Com efeito, os fatos jurídicos são fatos naturais e sociais que são coloridos pelo Direito, recebendo uma marca ou carimbo de sua relevância estampada pela norma jurídica $^{215}$.

Reconhecer que o mundo da realidade é muito mais amplo do que o mundo jurídico é fundamental na estruturação do pensamento e correta análise dos fenômenos, pois, significa compreender que todas as situações jurídicas são apenas imputações feitas pelas pessoas a certos acontecimentos da realidade por meio de normas jurídicas ${ }^{216}$. Nesse sentido, assevera F. C. PONTES DE MIRANDA, “[p]or falta de atenção aos dois mundos [mundo dos fatos e mundo dos fatos jurídicos] muitos erros se cometem e, o que é mais grave, se priva e inteligência humana de entender, intuir e dominar o direito" ${ }^{217}$.

212 Cf. G. RadBruch, Filosofia do Direito, trad. port. L. Cabral de Moncada, 6. ${ }^{\text {a }}$ ed., Coimbra, Arménio Amado, 1997, p. 79 e ss.

213 Cf. A. Tomasetti JR., Teoria Geral do Direito Privado, mimeo, São Paulo, 2004.

214 F. C. PONTES DE MIRANDA, Tratado de Direito Privado cit., t. I, §2, n. 2, p. 3: “Os fatos do mundo ou interessam ao direito, ou não interessam. Se interessam, entram no subconjunto do mundo a que se chama mundo jurídico e se tornam fatos jurídicos, pela incidência das regras jurídicas, que assim os assinalam". Cf. também M. Bernardes DE MEllo, Teoria do Fato Jurídico - Plano da Existência cit., p. 39. Um exemplo claro é a relação de amizade entre as pessoas, que sem dúvida, está entre os fatos mais corriqueiros do dia a dia e desempenha um papel principal na formação da personalidade e da própria sociedade. Entretanto, apesar de sua relevância na vida das pessoas, inexiste tratamento jurídico específico para o fato social e cultural amizade, que recebe uma disciplina indireta quando integra, junto com outros elementos, o suporte fático de determinadas normas jurídicas.

215 Cf. A. TOMASETti JR., Teoria Geral do Direito Privado, mimeo, São Paulo, 2004. F. C. PONTES DE MIRANDA: "O direito, na escolha dos fatos, que hão de ser regrados (= sobre os quais incide a regra), deixa de lado, fora do jurídico, muitos fatos, que a alguns observadores e estudiosos parecem dignos de regulação; mas esse julgamento dos técnicos do direito, ou dos não-técnicos, por mais procedente que seja, só se pode passar no plano político, moral ou científico, e nenhuma influência pode ter na dogmática jurídica. Enquanto a regra se não transforma em regra jurídica, isto é, enquanto não se faz incidível, cabe a crítica; não, depois. Só o direito separa os fatos que ele faz serem jurídicos, precisando linhas entre o jurídico e o aquém ou o além do jurídico (não-jurídico), como tira, ou acrescenta, ou altera alguns desses fatos para os fazer jurídicos; de modo que, ainda no tocante aos fatos do suporte fático das regras jurídicas, $o$ direito procede a esquematização do mundo físico, a fim de o fazer, até certo ponto e dentro de limites precisos, jurídico (principio da esquematização do Fático)" (Tratado de Direito Privado cit., t. I, §7. ${ }^{\circ}$, n. 2, p. 7).

216 M. Bernardes De Mello, Teoria do Fato Jurídico - Plano da Existência cit., p. 39.

217 Tratado de Direito Privado cit., t. I, pp. 3-4. F. C. PONTES DE MIRANDA emprega a expressão fáctico para designar o não jurídico e, por isso, fala sobre o mundo fáctico em oposição ao mundo jurídico. Todavia, 
Atentando-se para a distinção entre o mundo dos fatos e o mundo dos fatos jurídicos é possível identificar os momentos lógicos pelos quais o fenômeno jurídico, em sua dimensão normativa, dimensão política e dimensão sociológica, desenvolve-se ${ }^{218}$ : (1) definição pelo titular do poder de tomada de decisões normativas de fato juridicamente relevante e para o qual são imputadas consequências jurídicas por meio de norma jurídica; (2) a concreção do fato desenhado hipoteticamente na norma jurídica no mundo dos fatos; (3) a adjetivação do fato como jurídico e a sua entrada no plano da existência do mundo dos fatos jurídicas pela incidência da norma jurídica; (4) a passagem dos fatos jurídicos fundados na decisão humana pelo plano da validade, onde haverá o filtro das nulidades e das anulabilidades; e (5) a entrada do fato jurídico válido ou invalidado por anulabilidade no plano da eficácia onde são produzidas as situações jurídicas, as relações jurídicas, as posições jurídicas subjetivas ativas e passivas, simples ou complexas, que constituem o conteúdo próprio de cada fato jurídico ${ }^{219}$.

Uma vez que os momentos lógicos do fenômeno jurídico sejam corretamente dominados obtém um poderosíssimo mecanismo de análise e estudo do Direito, porque em qualquer circunstância os mesmos degraus da existência até a eficácia serão percorridos, conforme observa M. BERNARDES DE MELLO:

\footnotetext{
"Na análise da juridicidade se constata, com clareza, que tanto no sentido ascendente - iniciando-se da juridicização do suporte fáctico, quando surge o fato jurídico, à terminal eficácia jurídica - como num descendente - partindo-se da eficácia até encontrar a sua fonte, o fato jurídico - os degraus por que se tem de passar são sempre os mesmos, irremovíveis e inelimináveis. Há entre eles, evidentemente, uma relação implicacional, motivo pelo qual toda a vez que esse relacionamento é desconsiderado, eliminando-se ou desconhecendo-se algum de seus estágios, compromete-se a correção no trato dos assuntos jurídicos e se cria
}

conforme mencionado no texto, tanto o mundo fáctico como o mundo jurídico são compostos por fatos, de maneira que a expressão mais estrita para designar ambos os mundos consiste em falar no mundo dos fatos e nos mundos dos fatos jurídicos.

${ }_{218}$ Cf. M. Bernardes De Mello, Teoria do Fato Jurídico - Plano da Existência cit., p. 42.

219 Entender a profundidade de cada momento do fenômeno jurídico está no próprio fundamento do pensamento jurídico, uma forma de construir o raciocínio peculiar ao jurista mencionado por K. ENGISCH, Introdução ao pensamento jurídico, trad. port. João Baptista Machado, 9a ed., Lisboa, Fundação Calouste Gulbenkian, 2004. Contra L. AlEXANDER - E. SHERwIn, Demystifying Legal Reasoning, Cambridge Introductions to Philosophy and Law, Cambridge, 2008, para quem não existe uma maneira de raciocinar própria ao jurista, pois a chamada lógica jurídica não deixa de adotar os mesmos pressupostos lógicos e a mesma estrutura para a tomada de decisão que qualquer outra pessoa em sua vida diária e profissional. Com efeito, as críticas são pertinentes no tocante a reconhecer que o pensamento jurídico não cria uma nova estrutura lógica ou um modelo próprio de raciocinar, valendo-se de todo o arcabouço desenvolvido pela lógica, retórica, matemática, psicologia e ciências sociais. Por outro lado, rejeitar a existência de um pensamento peculiar ao jurista, que explora de modo consciente determinadas estruturas lógicas, como a subsunção, por exemplo, em detrimento a outras e emprega tais estruturas de maneira mais ou menos sistemática para interpretar, compreender e conformar o mundo. 
uma visão distorcida da realidade jurídica"220.

O primeiro momento lógico a ser observado, então, é a norma jurídica que faz a mediação entre os fatos e a juridicização dos fatos valorados relevantes o suficiente para serem coloridos como jurídicos.

\subsection{Norma jurídica e fato jurídico}

Segundo a posição adotada neste estudo, o mundo jurídico é composto por fatos que correspondem às situações hipotéticas descritas nas normas jurídicas ${ }^{221}$ e, por isso, sofreram a incidência de normas jurídicas e se tornaram aptos a gerar efeitos jurídicos, como a constituição de situações jurídicas e, especial, de relações jurídicas. É a norma jurídica, então, quem define o fato jurídico e é o ordenamento jurídico enquanto conjunto de normas que edifica o mundo dos fatos jurídicos como um todo ${ }^{222}$.

Talvez uma das mais infindáveis discussões jurídicas gire em torno da natureza da norma jurídica, muitas vezes definida como juízo hipotético, como imperativo ou imperativo condicionado. Não faz parte do presente estudo, nem impacta os resultados da pesquisa, adentrar no debate sobre a natureza da norma jurídica. Basta ter em mente que a norma jurídica apresenta-se no dia a dia das pessoas como o conteúdo semântico unitário decorrente de uma sequência de sinais léxicos linguísticos que exprimem em sua unidade uma decisão política do titular do poder de tomar decisões normativas ${ }^{223}$. Assumindo que a forma gramatical linguística por meio da qual um significado é expresso denomina-se enunciado, então a norma jurídica consiste em uma proposição ${ }^{224}$, um significado, que

\footnotetext{
220 Teoria do Fato Jurídico - Plano da Existência cit., p. 42.

221 Cf. A. Tomasetti Jr., Teoria Geral do Direito Privado, mimeo, São Paulo, 2004

222 Cf. M. BERnARDES DE MEllo, Teoria do Fato Jurídico - Plano da Existência cit., p. 50.

223 Cf. A. Tomasetti JR., Teoria Geral do Direito Privado, mimeo, São Paulo, 2004. Dizer que a norma jurídica é o significado unitário de uma decisão é reconhecer que a norma jurídica é, acima de tudo, fruto de uma ação comunicativa por parte do titular do poder de tomar decisões normativas.

224 Na teoria lógica, a proposição é tratada como o pensamento literalmente expresso por um enunciado com sentido. As diversas teorias lógicas apresentam conceitos próprios de proposição, como, por exemplo, o significado, o sentido, a intenção ou o conteúdo de um enunciado. Adota-se no texto, a teoria que enxerga a proposição como conteúdo semântico (ou significado), isto é, como exprimindo um estado de coisas que podem ou não subsistir no mundo real. D. K. LEWIS critica a definição estipulativa de proposição como conteúdo semântico porque o significado de enunciados só pode ser verdadeiro se houver identificação temporal ou espacial, o que nem sempre ocorre (On the Plurality of Worlds, Oxford, Blackwell, 1986). Por outro lado, J. C KING faz uma defesa fervorosa da proposição como conteúdo semântico por demonstrar que tempo e espaço são melhores definidos com expressões como "em algum lugar" ou "em algum momento".
} 
pode ser construído a partir de diversos enunciados ${ }^{225}$.

As proposições podem ser classificadas segundo sua forma gramatical ou segundo a sua função. Segundo o primeiro critério, as proposições, isto é, os conteúdos semânticos podem ser divididos em proposições declarativas, proposições interrogativas, proposições imperativas e proposições exclamativas ${ }^{226}$. Para qualquer pessoa com o mínimo conhecimento do vernáculo não há maiores dificuldades em discernir os traços identificadores de cada uma das espécies de proposições gramaticais. Assim, a atenção deve ser voltada ao critério funcional, por meio do qual as proposições podem ser classificadas em proposições descritivas (ou informativas), em proposições expressivas (ou avaliativas) e em proposições prescritivas ${ }^{227}$. As proposições descritas, próprias da linguagem científica, possuem como função fazer conhecer informações e, por isso, podem ser avaliadas logicamente a partir de sua correspondência ou não à realidade (ou seja, avalia-se se as proposições descritivas são verdadeiras ou falsas). Proposições expressivas, por outro lado, evidenciam certas crenças e sentimentos e tentam evocá-los no destinatário da proposição com o objetivo de fazêe-lo participar do estado sentimental. Já as proposições prescritivas consistem em comandos, conselhos, recomendações e advertências logrando influenciar a execução de alguma coisa, de maneira que em oposição às proposições descritivas, as proposições prescritivas não podem ser avaliadas com relação à verdade ou falsidade, mas apenas em relação à validade ou à invalidade, à efetividade ou à inefetividade ou quanto à justiça ou à injustiça ${ }^{228}$.

Não há dúvidas de que a norma jurídica seja uma proposição prescritiva, pois, conforme pondera N. BOBBIO, a discussão sobre se a norma jurídica é um imperativo ou

Tais expressões estão sempre implícitas nas proposições, assim, dizer “está chovendo" contém implicitamente a o conteúdo "em algum lugar, em algum momento, chove" (Tense, Modality, and Semantic Value, Philosophical Perspectives, 17, 2003, pp. 195-246). Para uma análise das críticas ao conceito de proposição como um todo, vide W. van ORMAN QuINE, Word and Object, Cambridge, MIT Press, 1960.

Cf. G. LumiA, Elementos da teoria e ideologia do direito, trad. port. Denise Agostinetti, São Paulo, Martins Fontes, 2003, p. 39; N. BoBBIO, Teoria da Norma Jurídica, trad. port. Fernando Pavan Baptista e Ariani Bueno Sudatti, 4. ${ }^{a}$ ed., Bauru, EDIPRO, 2008, p. 73. Vários enunciados podem expressar a mesma proposição, como, por exemplo, "José ama Maria" e "Maria é amada por José". Do ponto de vista léxico linguístico resta inegável que os enunciados são diferentes, mas qualquer pessoa com a mínima habilidade de compreensão de texto perceberá que ambos os enunciados possuem o mesmo significado (=conteúdo semântico).

226 Cf. N. BobBIO, Teoria da Norma Jurídica, trad. port. Fernando Pavan Baptista e Ariani Bueno Sudatti, 4. ${ }^{\text {a }}$ ed., Bauru, EDIPRO, 2008, p. 75.

227 Cf. G. LuMiA, Elementos da teoria e ideologia do direito, trad. port. Denise Agostinetti, São Paulo, Martins Fontes, 2003, p. 39. N. BoBBIO divide as proposições em asserções, perguntas, comandos ou exclamações (Teoria da Norma Jurídica, trad. port. Fernando Pavan Baptista e Ariani Bueno Sudatti, 4. ${ }^{\text {a ed., }}$ Bauru, EDIPRO, 2008, p. 75).

228 Cf. N. BobBIO, Teoria da Norma Jurídica, trad. port. Fernando Pavan Baptista e Ariani Bueno Sudatti, 4. ${ }^{\text {a }}$ ed., Bauru, EDIPRO, 2008, pp. 78-83. 
um juízo hipotético é um debate sobre a espécie, uma vez que tanto os imperativos como os juízos são, acima de tudo, proposições prescritivas que objetivam influenciar o comportamento dos sujeitos ${ }^{229}$. Enquanto proposição prescritiva a norma jurídica comanda a conduta dos destinatários por meio da atribuição, ou melhor, da imputação de certas consequências jurídicas aos fatos que ocorrem e acontecem no mundo ${ }^{230}$.

Partindo desse mecanismo de imposição de consequências a certos fatos, como ocorre na atribuição de inúmeros efeitos ao contrato de participação em grupo de consórcio, é possível representar estruturalmente a proposição prescritiva normativa a partir da descrição, do desenho esquemático de uma situação hipotética (Tatbestand, fattispecie, fatispécie, fato gerador, hipótese de incidência, suposto fático, hipótese jurídica, tipo legal, tipificação legal, pressuposto de incidência), e a prescrição dos efeitos que esta situação deve produzir no mundo do Direito, isto é, no mundo dos fatos jurídicos ${ }^{231}$. Então, uma proposição jurídica sem o desenho de uma situação hipotética ou sem a atribuição de consequência jurídica é incompleta e não pode incidir, pois uma norma que apenas esboçasse uma situação hipotética sem atribuir uma consequência jurídica é sem inútil do ponto de vista da ordenação da vida social, concomitantemente, uma consequência jurídica sem um fato ao qual seja atribuída é totalmente sem sentido na lógica jurídica $^{232}$.

229 Cf. Teoria da Norma Jurídica, trad. port. Fernando Pavan Baptista e Ariani Bueno Sudatti, 4. ${ }^{\mathrm{a}}$ ed., Bauru, EDIPRO, 2008, p. 144.

230 Cf. A. TOMASETti JR., Teoria Geral do Direito Privado, mimeo, São Paulo, 2004; K. ENGISCH, Introdução ao pensamento jurídico, trad. port. João Baptista Machado, $9^{\mathrm{a}}$ ed., Lisboa, Fundação Calouste Gulbenkian, 2004, p. 31; M. Bernardes DE Mello, Teoria do Fato Jurídico - Plano da Existência cit., p. 50 .

231 Cf. A. Tomasetti JR., Teoria Geral do Direito Privado, mimeo, São Paulo, 2004; Cf., também, embora com outra terminologia, M. BERnARdes DE MELlo, Teoria do Fato Jurídico - Plano da Existência cit., p. 50. E. BETTI resume a estrutura da norma jurídica com perspicácia: "A norma jurídica, considerada no seu arranjo lógico, consta de uma previsão e de uma disposição correspondente. Isto é, prevê, em abstracto e em geral, hipóteses de facto, classificadas por tipos e, ao mesmo tempo, orientadas segundo as dirctivas de uma valoração jurídica - hipóteses que, em terminologia técnica, são denominadas fattispecie -, $e$ estabelece-lhes um tratamento apropriado, relacionando com ela, através de uma síntese normativa, como se fosse 'efeitos', situações jurídicas correspondentes"(Teoria Geral do Negócio Jurídico, trad. port. Fernando de Miranda, t. I, Coimbra, Coimbra, 1969, pp. 17-18).

232 Exatamente pelo fato de não pode existir norma jurídica incompleta cabe ao jurista analisar os enunciados normativos com muito cuidado, pois não são raras as ocasiões nas quais a descrição da situação hipotética encontra-se enunciada em certo dispositivo enquanto a consequência jurídica é formulada em outro lugar, até mesmo em outro diploma normativo. É por isso que a compreensão do sistema jurídico de maneira integrada é essencial para a correta identificação das normas jurídicas enquanto conteúdos semânticos estruturados em situação hipotética e consequência jurídica. Como exemplo pode-se citar M. BERNARDES DE Mello exemplifica com o enunciado do art. 402 do Código Civil que discorre sobre o montante da indenização por dano emergente e lucro cessante: "Salvo as exceções expressamente previstas em lei, as perdas e danos devidas ao credor abrangem, além do que ele efetivamente perdeu, o que razoavelmente deixou de lucrar". Percebe-se claramente que o artigo em questão enuncia a consequência jurídica, mas não é em si uma proposição jurídica completa por faltar a descrição da situação hipotética, ainda que do ponto de 
O "fato, ou grupo de fatos" que corresponde ao desenho da situação hipotética da norma jurídica denomina-se suporte fático (Tatbestand), pois é o suporte "sobre o qual a regra jurídica incide ${ }^{233}$, um conceito do mundo dos fatos que corresponde ao esboço ${ }^{234}$, ao desenho hipotético da primeira parte da proposição jurídica. Como na construção da norma jurídica a situação hipotética traça com linhas até grosseiras um esboço do fato que demanda tratamento pelo Direito, o suporte fático em sua inteireza e complexidade não é alçado ao mundo jurídico como fato jurídico, mas tão somente parcela do evento ou da conduta que é juridicamente relevante ${ }^{235}$.

Uma vez concretizado o suporte fático, a norma jurídica instantaneamente, infalivelmente e de modo inesgotável, incide sobre este suporte fático, carimbando-o como jurídico e trazendo a parcela relevante do suporte fático para o mundo jurídico como fato jurídico $^{236}$. Fato jurídico em sentido amplo é, então, a parte do suporte fático sobre o qual a norma jurídica incide e imputa consequências jurídicas ${ }^{237}$, conforme se depreende do conceito exposto por F. C. PONTES DE MIRANDA:

\begin{abstract}
"fato jurídico é o que fica do suporte fático suficiente, quando a regra jurídica incide e porque incide. Tal precisão é indispensável ao conceito de fato jurídico. [...] Fato jurídico é, pois, o fato ou complexo de fatos sobre o qual incidiu a regra jurídica; portanto, o fato de que dimana, agora, ou mais tarde, talvez condicionalmente, ou talvez não dimane, eficácia jurídica. Não importa se é singular, ou complexo, desde que, conceptualmente, tenha unidade. A oferta é fato jurídico: produz efeitos jurídicos. A aceitação também os produz, porque é fato jurídico. O contrato que delas surge é fato jurídico, com suporte de dois fatos jurídicos: a regra jurídica incide sobre dois suportes fáticos, em correlação, dando ensejo, assim, à bilateralidade",238
\end{abstract}

Entender o fato jurídico como a parcela dos eventos e condutas que sofrem a incidência das normas jurídicas é, substancialmente, oposto à visão tradicional e

vista linguístico exista um conteúdo semântico facilmente compreensível. A situação hipotética que completa a proposição jurídica encontra-se no art. 389 do Código Civil: "Não cumprida a obrigação, responde o devedor por perdas e danos, mais juros e atualização monetária segundo índices oficiais regularmente estabelecidos, e honorários de advogado". Desse modo, os enunciados legais dos artigos 389 e 406 do Código Civil expressam apenas uma norma jurídica (Teoria do Fato Jurídico - Plano da Existência cit., p. 56).

F. C. PONTES DE MIRANDA, Tratado de direito privado cit, t. I, § 7. , n. 1, p 19.

234 Cf. A. Tomasetti Jr., Teoria Geral do Direito Privado, mimeo, São Paulo, 2004.

235 Cf. A. Tomasetti JR., Teoria Geral do Direito Privado, mimeo, São Paulo, 2004.

236 Cf. A. Tomasetti JR., Teoria Geral do Direito Privado, mimeo, São Paulo, 2004.

237 Cf. A. Tomasetti JR., Teoria Geral do Direito Privado, mimeo, São Paulo, 2004; M. BERNARDES DE MEllo, Teoria do Fato Jurídico - Plano da Existência cit., p. 145. Embora não deixe explícito o conceito de fato jurídico, E. BETTI constrói o raciocínio

238 Tratado de Direito Privado cit, t. I, p. 77. 
dominante $^{239}$ do fato jurídico como o acontecimento que produz o nascimento, a modificação ou a extinção de relações jurídicas. Do ponto de vista metodológico, o conceito desenhado pela visão tradicional procura desenhar o fenômeno fato jurídico pela sua consequência, identificando corretamente que se existem efeitos jurídicos há fato jurídico em algum lugar do mundo jurídico ${ }^{240}$, mas conceituação dos fenômenos pelos efeitos, embora faça parte da metodologia científica, possui o risco de captar apenas parcelas do fenômeno estudado, deixando de lado fenômenos que são substancialmente os mesmos, mas que geram efeitos distintos ${ }^{241}$. Ao discutir sobre os fatos jurídicos, a doutrina tradicional acaba por perder de foco - e tal distorção pode gerar conclusões errôneas quando aplicada à classificação do contrato de participação em grupo de consórcio - que nem todo fato jurídico produz os efeitos jurídicos próprios descritos na consequência jurídica da proposição jurídica. Como se mostrará, alguns fatos são retidos no plano da validade e assim não produzem efeitos, enquanto outros, apesar de serem válidos, carecem de fatores que lhe permitam a plena produção de efeitos ${ }^{242}$.

Uma vez que seja estipulado o conceito de fato jurídico como a parcela do suporte fático sobre o qual incidiu a norma jurídica que é trazida para o mundo jurídico é preciso, de maneira sumarizada, considerar quais são os elementos do suporte fático e a sua relevância na existência, na validade e na eficácia dos fatos jurídicos.

239 Cf. F. Amaral, Introdução ao Direito Civil, 7. a ed., Rio de Janeiro, Renovar, 2008, p. 379; O. Ascensão, Direito Civil, v. 2, Ações e fatos jurídicos, 3. a ed., São Paulo, Saraiva, 2010, pp. 9-31; C. A. Mota PINTO, Teoria geral do direito civil. $3^{\mathrm{a}}$ ed., Coimbra, Coimbra Editora, 1999, pp. 353-358.

240 Explica F. C. PONTES DE MIRANDA que "Eficácia jurídica é o que se produz no mundo do direito como decorrência dos fatos jurídicos" (Tratado de Direito Privado cit, t. I, § 1., n. 4, p. 4).

241 Outra consequência da definição dos fenômenos pelos seus efeitos é atentar mais para a patologia, a exceção que confirma a regra, do que para a produção de efeitos dentro do padrão aceitável de normalidade.

${ }_{242}$ Todo o fato jurídico, mesmo o eivado de nulidade, produz algum tipo de efeito no mundo jurídico, mas esse efeito não é o efeito jurídico próprio, previsto na consequência jurídica da norma jurídica que incidiu sobre o suporte fático. 


\subsection{Elementos do suporte fático}

Deve-se ter em mente que o suporte fático é conceito do mundo dos fatos, é a parcela do acontecimento que corresponde ao esboço desenhado na situação hipotética e, por isso, recebe a incidência da norma jurídica, que juridiciza ${ }^{243}$ parcela ou a totalidade do suporte fático trazendo-a para o mundo jurídico como fato jurídico. Não se pode confundir o suporte fático com a situação hipotética que compõe a primeira parte da proposição jurídica $^{244}$.

Na definição dos contornos da situação hipotética pode o titular do poder de tomar decisões normativas incluir como suporte fático da norma jurídica uma série de elementos e acontecimentos diferentes, quais sejam: (1) eventos; (2) condutas; (3) dados psíquicos; (4) estimações valorativas; (5) probabilidades; (6) fatos jurídicos e efeitos jurídicos; (7) causalidade física; (8) tempo; (9) elementos positivos; (10) elementos negativos; (11) elementos subjetivos; e (12) elementos objetivos ${ }^{245}$.

Dentre os diversos elementos que podem compor o suporte fático, alguns comentários devem ser tecidos com relação ao elemento subjetivo, por tratar-se de elemento necessário e inafastável do suporte fático, na medida em que o Direito é um fenômeno cultural voltado à conformação e à adaptação da conduta das pessoas. Os efeitos jurídicos somente se produzem em relação a uma pessoa, natural ou coletiva, ou a um ente que, mesmo não sendo dotado de personalidade, o ordenamento jurídico reconhece como sujeito de posições jurídicas subjetivas ${ }^{246}$, e por tal razão todo o suporte fático deve conter

243 Conforme o Vocabulário Ortográfico da Língua Portuguesa (VOLP), preparado pela Academia Brasileira de Letras (5. a ed., Rio de Janeiro, Global, 2009), o vernáculo não admite o verbo "juridicizar" e palavras derivadas. Adota-se no texto, porém, no sentido do neologismo criado por F. C. PONTES DE MIRANDA para designar a ação de tornar jurídico alguma coisa, mais propriamente tornar um acontecimento do mundo dos fatos em um fato jurídico integrante do mundo jurídico.

244 Cf. A. Tomasetti Jr., Teoria Geral do Direito Privado, mimeo, São Paulo, 2004.

245 Para uma análise detalhada de cada um dos elementos que podem compor o suporte fático, vide $\mathrm{M}$. Bernardes de Mello, Teoria do Fato Jurídico - Plano da Existência cit., pp. 76-82.

246 Cf. A. Tomasetti JR., Teoria Geral do Direito Privado, mimeo, São Paulo, 2004. No ordenamento jurídico pátrio, conforme demonstrou M. BERNARDES DE MELlo, o conceito de sujeito de posições jurídicas subjetivas é mais amplo do que o conceito de pessoa, pois existem entes para os quais as normas jurídicas atribuem posições jurídicas subjetivas, ativas ou passivas, ainda que seja a mera capacidade de comparecer em juízo como réu, sem lhes conferir a personalidade, isto é, um centro de imputação autônomo de posições jurídicas subjetivas, ativas e passivas, simples ou complexas (Teoria do Fato Jurídico - Plano da Eficácia, $1^{a}$ parte, $8^{\text {a }}$ ed., São Paulo, Saraiva, 2013, pp. 163 e ss.). Esse assunto será retomado posteriormente quando discutida natureza do grupo de consórcio; por hora, o melhor exemplo de atribuição de posições jurídicas subjetivas sem a atribuição de personalidade é o nascituro. Prescreve a parte final do art. $2 .^{\circ}$ do Código Civil que "a lei põe a salvo, desde a concepção, os direitos do nascituro". Ao mencionar os direitos, ou melhor, posições jurídicas subjetivas do nascituro, a proposição jurídica está explicitamente atribuindo tais posições 
a referência a um sujeito que será objeto da imputação de situações jurídicas.

$\mathrm{Na}$ análise do suporte fático há de se atentar para existência de um elemento cerne, nuclear, que determina a configuração final do fato jurídico e o momento de sua concreção, e elementos que completam o suporte fático, denominados de elementos completantes. Em termos simples, o elemento cerne, ou o conjunto de elementos cerne do suporte fático, relaciona-se à licitude ou ilicitude e à espécie do fato jurídico (fato jurídico stricto sensu, ato-fato jurídico, ato jurídico lato sensu ou negócio jurídico), enquanto os elementos completantes resultam na categorização do fato jurídico dentro de sua respectiva espécie $^{247}$. Por exemplo, caracteriza a espécie negócio jurídico o elemento cerne (1) conformidade ao Direito; e (2) decisão tomada com poder de autorregramento, enquanto o elemento completante acordo para a disposição de bem contra o pagamento de certo preço configura o contrato de compra-e-venda, que é modalidade de negócio jurídico bilateral e patrimonial.

Ao analisar a multiplicidade do elemento volitivo nos negócios jurídicos, F. C. PONTES DE MIRANDA ressalta o papel nuclear desempenhado por alguma das exteriorizações de vontade, definindo o conteúdo específico do negócio jurídico de maneira tão sensível que "sem esse elemento, ou o negócio jurídico não seria, ou seria outro negócio jurídico" ${ }^{248}$. Os demais elementos volitivos, inclusive os decorrentes da incidência de normas dispositivas e supletivas, transladam em torno do núcleo "sem que sejam necessários à determinação do conteúdo específico do negócio jurídico”. Ou seja, enquanto a falta do elemento volitivo nuclear do negócio jurídico repercute no plano da existência, fazendo nenhum o negócio ou criando negócio jurídico de outra categoria, a insuficiência de qualquer elemento complementar ao núcleo não impacta a natureza mesma do negócio jurídico ${ }^{249}$. Exemplificativamente, são elementos complementares do suporte fático dos atos jurídicos lato sensu, verdadeiros pressupostos de validade ou eficácia, a

ao nascituro e, portanto, transforma-o em sujeito de posições jurídicas subjetivas. Contemporaneamente, a primeira parte do art. 2. ${ }^{\circ}$ do Código Civil enuncia uma segunda proposição jurídica completa no sentido de que a "personalidade civil da pessoa começa do nascimento com vida". Não se trata de antecipação da eficácia com caráter resolutivo ou da atribuição de personalidade, visto que a enunciação das duas normas no mesmo dispositivo legal, embora questionável do ponto de vista da técnica de redação de diplomas normativos, acaba por reforçar que a atribuição das posições jurídicas subjetivas é realizada sem conferir-lhe a personalidade. Eventuais considerações éticas sobre o conceito de pessoa sem dúvida estão nos fundamentos da atribuição ao nascituro da situação jurídica de sujeito de posições jurídicas subjetivas e devem ser levadas em conta na identificação concreta de quais são as posições jurídicas atribuídas, mas nem por isso tornam o nascituro como pessoa caracterizada como um centro autônomo de imputação de posições jurídicas subjetivas.

247 Cf. M. Bernardes de Mello, Teoria do Fato Jurídico - Plano da Existência cit., p. 87.

248 Tratado de Direito Privado cit., t. III, $\$ 251$, n. 4, p. 211.

249 Cf. Tratado de Direito Privado cit., t. III, § 251, n. 4, p. 211. 
legitimidade, a capacidade de agir, a forma prescrita para o ato e o poder de disposição.

Retomando a distinção acima, M. BERNARDES DE MELLO construiu uma estrutura de pensamento do fenômeno jurídico englobante de outros dados além do elemento cerne e dos elementos completantes, afirmando que o suporte fático sobre o qual incide a norma jurídica pode ser composto por elementos complementares e elementos integrativos de eficácia $^{250}$. Segundo a proposta do autor, o elemento cerne e os elementos completantes formam o núcleo do suporte fático, que possui influência direta na existência do fato jurídico, pois a norma jurídica somente incidirá quando estiverem concretizados todos os elementos nucleares do suporte fático. Se faltar elemento cerne ou elemento completante o suporte fático não é suficiente e, por isso, a norma jurídica não incide sobre ele ${ }^{251}$. Por outro lado, os elementos complementares e integrativos verificam-se apenas em relação aos atos jurídicos stricto sensu e aos negócios jurídicos e impactam o plano da validade ou da eficácia. Assim, se houver a concreção do núcleo do suporte fático, a norma jurídica incide sobre ele e surge fato jurídico no plano da existência, mesmo se faltar algum elemento complementar ou integrativo, o que faz com que o fato jurídico em questão não seja válido ou não produza os efeitos finais ${ }^{252}$.

É preciso atentar para a função simplificadora desempenhada pela distinção entre elementos nucleares, complementares e integrativos do suporte fático, enquanto um expediente teórico para análise dos fatos jurídicos e especial dos atos e negócios jurídicos. Deve-se tomar cuidado especial para não associar os elementos complementares e integrativos com a parcela não essencial do suporte fático de determinada norma jurídica. Dizer que a observância de determinada regra sobre forma do negócio significa apenas reconhecer que a conduta dita nuclear ao suporte fático de negócio jurídico sofre uma chuva de incidências de um leque de normas jurídicas completas, descrevendo as situações hipotéticas e imputando diversas consequências jurídicas relacionadas à validade é à eficácia desse negócio jurídico. A menção aos elementos complementares e integrativos é uma forma de sistematizar o pensamento do jurista, sintetizando uma série de normas jurídicas qualificadoras da exteriorização de vontade do sujeito. Basta pensar na exigência de escritura pública para a validade dos negócios com a finalidade constituição, transferência, modificação ou renúncia de direitos reais sobre imóveis de valor superior a

\footnotetext{
250 Cf. Teoria do Fato Jurídico - Plano da Existência cit., pp. 85-99.

251 Cf. Teoria do Fato Jurídico - Plano da Existência cit., p. 85.

252 Cf. Teoria do Fato Jurídico - Plano da Existência cit., pp. 95-99.
} 
trinta vezes o maior salário mínimo vigente, enunciada no art. 108 do Código Civil ${ }^{253}$. A escritura pública pode ser classificada como elemento complementar do contrato de compra-e-venda de bem imóvel em valor que supere trinta vezes o salário mínimo, mas é incorreto concluir daí que o enunciado do art. 108 integra-se na proposição enunciada pelo art. $481^{254}$ de forma que o suporte fático descrito na proposição jurídica sobre compra-evenda inclua a escritura pública. Uma conclusão no sentido diverso acabaria por transformar o art. 108 no enunciado de uma norma meramente integrativa, incapaz de incidir por si, tão somente dando detalhes ou cores ao esboço de acontecimento descrito na proposição jurídica enunciada no art. 181, resultando no reconhecimento como proposição jurídica completa apenas as normas jurídicas juridicizantes, com a exclusão lógica das normas jurídicas cuja eficácia normativa é a invalidação, pré-exclusão de juridicidade, deseficacização e desjuridização ${ }^{255}$. De fato, se proposição jurídica contiver "diferenças entre elementos do suporte fático, é que há, na verdade, duas ou mais regras jurídicas",256, uma vez que "[s] e a regra jurídica A considera necessários a, a' e a" para que o fato seja jurídico, mas prevê que seja nulo, ou anulável, ou rescindível, se falta a”, a”, ou se ocorre a",", esses elementos são suporte fático de outras regras jurídicas" ${ }^{, 257}$.

\subsection{A incidência da norma jurídica sobre o suporte fático}

Quando é ocorre no mundo fático um acontecimento que corresponde à situação hipotética descrita na norma jurídica, o suporte fático dessa norma fez-se suficiente e essa norma incide sobre ele para trazê-lo ao mundo jurídico como fato jurídico. O efeito das normas jurídicas, efeito típico e exclusivo do fenômeno jurídico, consiste em incidir sobre suportes fáticos. "A incidência é, assim, o efeito da norma jurídica de transformar em fato jurídico a parte de seu suporte fático que o direito considerou relevante para ingressar no

\footnotetext{
253 "Não dispondo a lei em contrário, a escritura pública é essencial à validade dos negócios jurídicos que visem à constituição, transferência, modificação ou renúncia de direitos reais sobre imóveis de valor superior a trinta vezes o maior salário mínimo vigente no País".

254 "Art. 481. Pelo contrato de compra e venda, um dos contratantes se obriga a transferir o domínio de certa coisa, e o outro, a pagar-lhe certo preço em dinheiro."

255 F. C. PONTES DE MIRANDA, Tratado de direito privado cit, t. I, § 13, n. 2, p. 33: "Não é regra jurídica somente o que, incidindo sobre o fato, faz nascerem direitos, pretensões, ações e exceções, ligadas à juridicização do fato; também no são as regras que, incidindo sobre o fato, dão ensejo a direitos, pretensão, ações, ou exceções, ligadas à negativa de juridicização (= inexistência), de validade (= nulidade; = anulação), ou de irrescindibilidade, ou de eficácia". Para uma análise das diversas eficácias da norma jurídica, cf. M. Bernardes DE Mello, Teoria do Fato Jurídico - Plano da Existência cit., pp. 128-132.

256 Tratado de direito privado cit, t. I, § 13, n. 1, p. 33.

257 Tratado de direito privado cit, t. I, § 13, n. 1, p. 33, reforços gráficos não originais.
} 
mundo jurídico" ${ }^{, 258}$. O quadro mental proposto de F. C. PONTES DE MIRANDA ajuda a visualizar o mecanismo da incidência: "Numa e noutra espécie, ocorridos certos fatosconteúdo, ou suportes fáticos, que têm de ser regrados, a regra jurídica incide. A sua incidência é como a da plancha da máquina de impressão, deixando a sua imagem colorida em cada folha"259. Somente é possível pensar em efeitos jurídicos, isto é, situações jurídicas, após a incidência da norma sobre o suporte fático e entrada respectivo fato no mundo jurídico. Há duas ordens de eficácia diferentes, a eficácia normativa ou eficácia das normas jurídicas e que pode ser resumida no poder de incidir sobre suportes fáticos e transformá-los em fatos jurídicos, e a eficácia jurídica ou eficácia dos fatos jurídicos, consistindo na criação, modificação, regulação e extinção de situações jurídicas. A proibição, a permissão e a obrigação de condutas é fruto dessa interdependência e reciprocidade entre fato e norma jurídica, pois não é a norma sozinha que obriga a essa ou aquela conduta, mas somente a norma jurídica que incidiu sobre seu suporte fático ${ }^{260}$.

Conforme discutido, nem todo o fático compõe o suporte fático da norma jurídica, mas apenas aquela parcela do fato correspondente à descrição esquemática contida na situação hipotética, de maneira que "não se há de pensar" que a parte não essencial do evento ou da conduta "faça parte do suporte fático", pois "suporte fático então é apenas a soma do que é essencial" ${ }^{261}$. Suporte fático é a parcela do fato que sofreu a incidência da norma jurídica e foi juridicizado, trazido para o mundo jurídico, conforme adverte F. C. PONTES DE MIRANDA “[t]em-se procurado distinguir o que é essencial e o que não é essencial no suporte fático [...] porém tal distinção desatende a que, se algo não é essencial, a regra jurídica incide, a despeito da falta"262.

Repousa a força impositiva do Direito no mecanismo da incidência, caracterizado por ser inesgotável e incondicional, pois não importa se os sujeitos querem ou não ou se estão cônscios do significado jurídico ou das consequências de seus atos e decisões, a norma jurídica incidirá sobre o agir humano que corresponder à situação hipotética da proposição jurídica, não importa quantas vezes for concretizado o suporte fático da norma. O pressuposto da incidência é a existência de norma jurídica válida e vigente, isso é, dotada da possibilidade de incidir. Como a incidência é infalível, realizados os fatos previstos na situação hipotética da norma jurídica, ela incide sobre este suporte fático,

\footnotetext{
258 Cf. M. Bernardes de Mello, Teoria do Fato Jurídico - Plano da Existência cit., p. 108.

$259 \quad$ Tratado de direito privado cit, t. I, p. 11.

260 Cf. E. Betti, Teoria Geral do Negócio Jurídico cit., vol. I, p. 23.

261 Tratado de direito privado cit, t. I, § 13, n. 1, p. 33.

262 Tratado de direito privado cit, t. I, § 13, n. 1, p. 33
} 
criando no mundo jurídico um fato jurídico em sentido mais lato possível, com imediata produção da consequência jurídica prevista na norma. Importante notar que incidência independe da aplicação da norma jurídica. Por motivos vários, uma norma jurídica pode não ser observada e aplicada, mas isso nada modifica a incidência da norma jurídica e a criação de fatos jurídicos. A incidência é eficácia normativa; a aplicação é efetividade da norma jurídica. Há, ainda, a eficácia jurídica, que consiste nos efeitos dos fatos jurídicos como imputados pelas normas jurídicas. Eficácia normativa e eficácia jurídica são temas que cabem ao jurista tratar, mas, quanto à efetividade do direito, o jurista necessita de inputs de outras áreas do conhecimento, como a antropologia e a sociologia ${ }^{263}$.

\subsection{O fato jurídico e suas espécies}

Os fatos jurídicos são divididos em espécies conforme a valoração jurídica dos eventos e condutas, a saber: (1) os eventos configuram os fatos jurídicos "stricto sensu"; (2) as condutas humanas cuja valoração do sujeito e poder de decisão são juridicamente irrelevantes configuram os atos-fato jurídicos; e (3) as condutas cuja valoração e poder de decisão são juridicamente relevantes configuram os atos jurídicos "lato sensu", que se subdividem em atos jurídicos stricto sensu e negócios jurídicos ${ }^{264}$.

Dentro da categoria dos atos jurídicos lato sensu, temos uma subdivisão entre ato jurídico stricto sensu e negócio jurídico. A decisão do sujeito é relevante em ambas espécies, mas, a amplitude desta decisão é variável. No ato jurídico "stricto sensu” decidese apenas pela prática ou não do ato, com todos os efeitos pré-estabelecidos pelas normas jurídicas e inalteráveis. Para a consecução do interesse só há um ato jurídico possível, sem possibilidade de escolha entre diversas categorias jurídicas. O negócio jurídico é a espécie de fato jurídico na qual há uma decisão juridicamente relevante e apta a escolher, dentro

\footnotetext{
263 Cf. F. C. PONTES DE MIRANDA, Tratado de direito privado, t. I, cit., § $4^{\text {o }}$, n. 5, p. 12 e ss.

264 Esta é a classificação proposta por F. C. PONTES DE MIRANDA: "A classificação principal dos fatos jurídicos é em relação à origem do elemento fático (origem extra-humana e origem humana, origem humana que se apaga porque o direito, na espécie, somente vê o fato como extra-humano). Após ela vem a classificação binária conforme a atitude da Lei, isto é, conforme a licitude e a ilicitude. Os fatos jurídicos lato sensu entram em quatro classes: fatos jurídicos stricto sensu, atos-fatos jurídicos, atos jurídicos stricto sensu, negócios jurídicos. Não há quinta classe - ou melhor, pode não haver quinta classe - porque o elemento orgânico está, aí, inserto no todo, em que o inorgânico também aparece. Qualquer das quatro classes tem de se dividir conforme a licitude ou a ilicitude. Tanto há fatos (jurídicos) ilícitos stricto sensu, e atos-fatos jurídicos ilícitos como atos jurídicos stricto sensu e negócios jurídicos ilícitos" (Tratado das ações, t. I, São Paulo: Revista dos Tribunais, 1970, § 2º n.1).
} 
dos contornos do ordenamento jurídico, a categoria jurídica mais adequada para a satisfação do interesse do sujeito, mediante a possibilidade de estruturação dos efeitos jurídicos $^{265}$.

Importante ressaltar que, ao contrário do que se costuma afirmar, os atos jurídicos lato sensu prescindem de qualquer exteriorização de vontade, pois conforme demonstram recentes pesquisas psicológicas e neurológicas, a vontade em si é irrelevante para a vida social $^{266}$ : o tecido social e a própria sobrevivência no ambiente dependem da aptidão para tomar decisões ${ }^{267}$. Tais estudos recentes relacionam o poder de decidir com a função executiva do cérebro, que divide o processo $^{268}$ decisório em três fases ${ }^{269}$ : (1) deliberação entre as possíveis alternativas; (2) escolha da alternativa e desenvolvimento de um plano de ação; e (3) realização do plano traçado. A fase deliberativa consiste na comparação das alternativas, pesando seus prós e contras. O momento da escolha significa a seleção de uma alternativa e o autocomprometimento para realizar um comportamento em harmonia com a alternativa escolhida. Por fim, a execução compreende os comportamentos que efetivam a alternativa escolhida e o plano de ação traçado. Todo esse processo ocorre, nos mais das vezes, em poucos instantes. O gasto de energia psíquica com a decisão é enorme, afinal, toda decisão envolve um comportamento para realizar o plano traçado. A vontade, o querer alguma coisa, fica em outra região cerebral e não tem relação direta com o comportamento. Ora, se o Direito regra comportamentos, ele não atua no campo da vontade, mas da decisão. O Direito atua sobre os comportamentos orientados à execução de um plano de ação, após uma deliberação. O Direito atua, assim, no campo das decisões e não da vontade. Todo comportamento humano, o agir e o não agir, não passa de um momento da decisão, mas é o momento sobre o qual o Direito pode atuar, obrigando, proibindo ou permitindo.

265 Em linguagem matemática, o ato jurídico stricto sensu é binário, pratica-se (1) ou não se pratica (0). O negócio jurídico é decimal, podendo ser composto por uma infinita combinação de números representados por dez algarismos (0 a 9). O sujeito não só tem a escolha de praticar ou não o negócio (0 e 1), mas a possibilidade maior ou menor de modificar o conteúdo do negócio por inserir diversos algarismos.

266 K. D. VOHS et al, Making choices impairs subsequent self-control: a limited-resource account of decision making, self-regulation, and active initiative, in Journal of Personality and Social Psychology, v. 94, n. ${ }^{\circ}$ 5, 2008; N. NOVEMSKY - R. DHAR, Goal fulfillment and goal targets in sequential choices, in Journal of Consumer Research, vol, 32, dez, 2005.

267 Cf. K. D. VoHS et al, Making choices impairs subsequent self-control: a limited-resource account of decision making, self-regulation, and active initiative, cit., p. 884.

268 Mais uma vez, a palavra processo não é empregada aqui em seu sentido técnico-jurídico.

269 Cf. K. D. VoHS et al, Making choices impairs subsequent self-control: a limited-resource account of decision making, self-regulation, and active initiative, cit., p. 892. 


\subsection{Suporte fático suficiente, suporte fático deficiente e suporte fato eficiente}

Sempre que o suporte fático é suficiente (= correspondente à situação hipotética descrita na norma jurídica) a norma incide sobre este suporte fático e ele passa a existir no mundo jurídico como fato jurídico. Entretanto, embora o suporte fático seja suficiente, ele pode ser deficiente, isto é, carece de elementos complementares à sua validade ou à sua eficácia. No caso do ato jurídico lato sensu, condutas juridicamente dependentes de valoração e poder de decisão, o ato jurídico passará pelo crivo de sua validade, ou seja, o ordenamento jurídico fará uma valoração a respeito da decisão tomada pelo sujeito. Por fim, os fatos jurídicos são analisados quanto à sua eficácia, sua aptidão para produzir efeitos. Desse modo, o mundo jurídico pode ser classificado em três planos, conforme tradicional lição de F. C. PONTES DE MIRANDA:

\footnotetext{
"No mundo jurídico, há três planos diferentes: o plano da existência, em que há fatos jurídicos e não mais suportes fáticos; o plano da validade quando se trata de ato humano e se assenta que é válido, ou não-válido (nulo ou anulável ), o plano da eficácia em que se irradiam os efeitos dos fatos jurídicos: direitos, deveres; pretensões, obrigações; ações, em sua atividade (posição de autor) e em sua passividade (posição do réu), exceções" 270 .
}

A divisão do mundo jurídico nos planos da existência, da validade e da eficácia é, acima de tudo, uma poderosa técnica analítica de estudo dos fatos jurídicos e, principalmente, do negócio jurídico por meio de um processo de eliminação progressiva, consoante explica A. JUNQUEIRA DE AZEVEDO:

“O exame do negócio, sob o ângulo negativo, deve ser feito através do que
batizamos com o nome de técnica de eliminação progressiva. Essa técnica
consiste no seguinte: primeiramente, há de se examinar o negócio jurídico da
existência e, aí, se ele existe, ou não existe. Se não existe, não é negócio
jurídico, é aparência de negócio (dito 'ato inexistente') e, então, essa
aparência não passa, como negócio, para o plano seguinte, morre no plano da
existência. No plano seguinte, o da validade, já não entram os negócios
aparentes, mas sim somente os negócios existentes; nesse plano, os negócios
existentes serão, ou válidos, ou inválidos; se forem inválidos, não passam para
o plano da eficácia, ficam no plano da validade; somente os negócios válidos
continuam e entram no plano da eficácia. Nesse último plano, por fim, esses
negócios, existentes e válidos, serão ou eficazes ou ineficazes (ineficácia em 
sentido estrito), 271 .

\subsection{Tipologia dos efeitos dos fatos jurídicos}

Em suma, é importante lembrar que no plano da existência entram todos os fatos jurídicos, lícitos ou ilícitos, nulos ou anuláveis e ineficazes. Passam pelo plano da validade os atos jurídicos stricto sensu e os negócios jurídicos, para que a decisão do sujeito seja juridicamente valorada. No plano da eficácia, são admitidos e podem produzir efeitos todos os fatos jurídicos, inclusive os anuláveis e ilícitos e, excepcionalmente, os nulos quando norma jurídica atribuir-lhe eficácia expressamente (= eficácia putativa) ${ }^{272}$.

Denomina-se situação jurídica o conjunto de consequências jurídicas produzidas pelos fatos jurídicos lato sensu que são admitidos no plano da eficácia. A situação jurídica é, assim, o efeito do fato jurídico de atribuição de uma posição a um sujeito de direito no mundo jurídico. Engloba todas as categorias eficaciais decorrentes de fatos jurídicos, desde as simples qualificações e qualidades jurídicas ${ }^{273}$ às relações jurídicas ${ }^{274}$. A mais importante das situações jurídicas é a relação jurídica ${ }^{275}$. Do ponto de vista lógico, relação é uma estrutura formal composta de um termo antecedente (ou referente) e um termo consequente (ou relato) e um operador relacional, de maneira que dizer "igual a", "menor que", "tantas vezes a" são operadores relacionais tais como o "ser titular de direito a" ou "ser obrigado a"276.

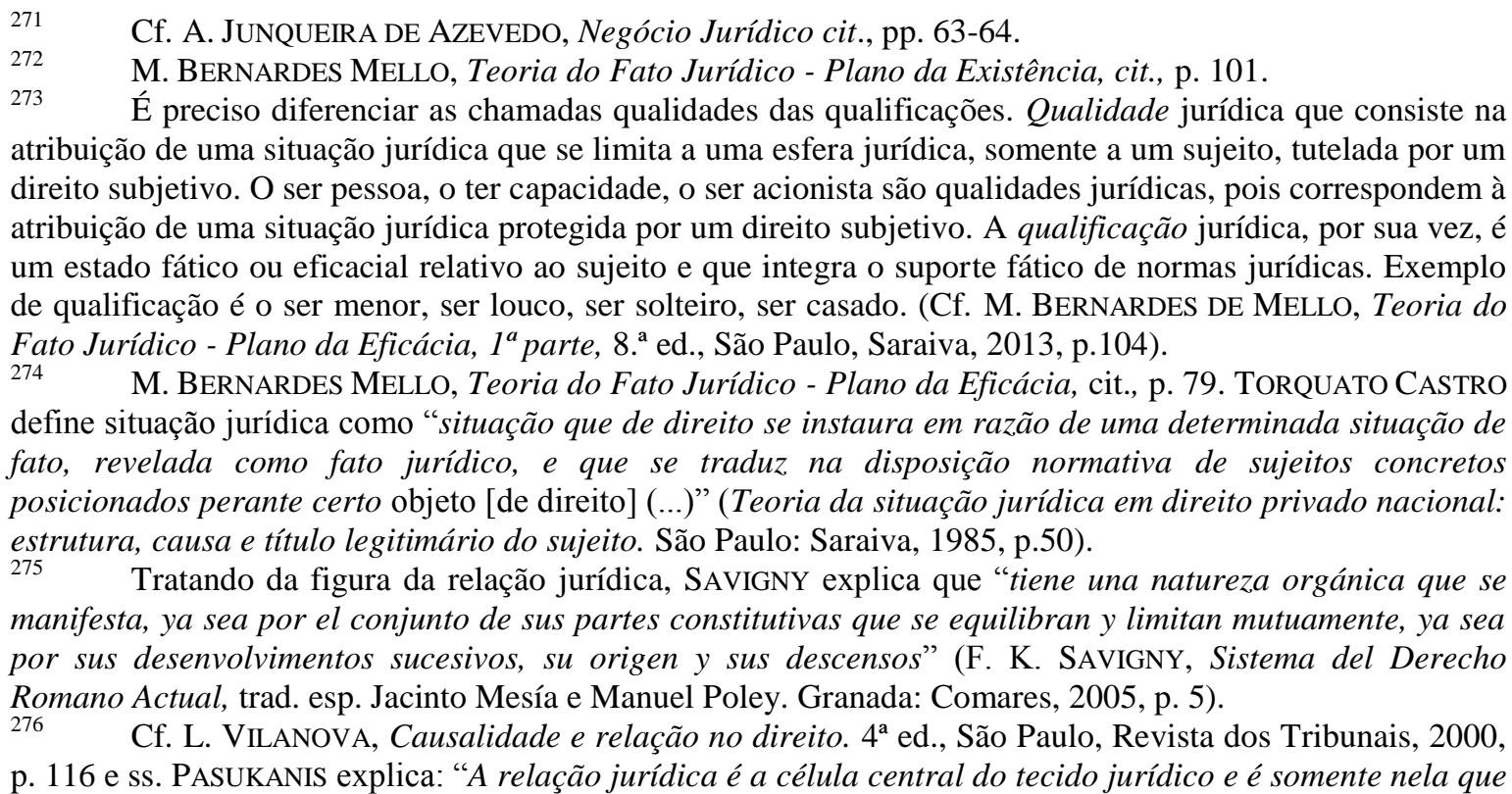


A lógica relacional está no próprio fundamento do Direito, que deve oferecer critérios para decidir conflitos intersubjetivos de interesses com a menor perturbação social possível $^{277,} \mathrm{O}$ interesse consiste na relação de complementaridade entre o sujeito que experimenta uma necessidade e o ente apto a satisfazer tal necessidade ${ }^{278}$. Aquilo que pode satisfazer tais necessidades é denominado "bem”. Por sua vez, o grau de satisfação proporcionado pelo bem varia de sujeito para sujeito e configura a utilidade desse bem. Consequentemente, o interesse é a utilidade específica de determinado bem para certo sujeito $^{279}$. Entretanto, o mundo é incapaz de oferecer bens suficientes para satisfazer todas as necessidades humanas, que crescem em progressão geométrica, enquanto os bens são “produzidos" em progressão aritmética. Como resultado da escassez de bens, muitas vezes a satisfação da necessidade de $A$ depende do mesmo bem apto a satisfazer a necessidade de $B$. Ou seja, a satisfação de um consiste na exclusão do outro ${ }^{280}$. Diz-se que há conflito entre o interesse de $A$ e o interesse de $B^{281}$. Para decidir tal conflito de interesses, o Direito, obriga, proíbe ou permite condutas, segundo modelos típicos de comportamentos esperados. Mas, só faz sentido obrigar, proibir ou permitir condutas quando estas condutas são posicionadas em relação a outro sujeito ${ }^{282}$, pois a vida social é relacional, dependente de interações entre seres; as normas jurídicas regulam e orientam estas interações pela utilização da técnica da relação jurídica ${ }^{283}$. A relação jurídica é sempre efeito de fato jurídico, não podendo existir fora do plano da eficácia ${ }^{284}$, e cujos são os sujeitos, a quem o ordenamento jurídico atribui posições jurídicas subjetivas ${ }^{285}$. Destarte, entende-se por

o direito realiza o seu movimento real" (PASUKANIS, Eugeny Bronislanovich. Teoria geral do direito e o marxismo. Trad. port. Paulo Bessa. Rio de Janeiro: Renovar, 1989, p. 55).

277 Cf. TÉRCIO SAMPAIO FerRAZ JR., Introdução ao Estudo do Direito cit., p. 84.

278 Cf. F. CARNelutTI, Teoria Generale del Diritto, 3. ${ }^{a}$ ed. Roma, Foro Italiano, 1951. p. $11 \mathrm{e}$ seguintes.

${ }_{279}$ Para uma súmula das diversas concepções de interesse na literatura jurídica, vide P. Mota Pinto, Interesse Contratual Negativo e Interesse Contratual Positivo, vol. I, Coimbra, Coimbra, 2008. p. 481 e seguintes.

${ }_{280} \quad$ "O elemento econômico do direito é o conflito de interesses. Onde não há conflito de interesses, não pode haver direito, porque nessa hipótese não há necessidade de direito. Não existe fenômeno jurídico na raiz do qual a análise não procure este conflito" (F. CARNELUTTI, Teoria Generale del Diritto cit., p. 14, tradução livre do original: "L'elemento econômico del diritto è il conflitto di interessi. Dove il conflitto di interessi non c'è non há ragione di essere il diritto; non esiste um fenômeno giuridico, Allá radice Del quale l'analisi non rintracci tale conflitto").

281 Cf. F. CARnelutTi, Teoria Generale del Diritto p. 11-12.

282 Cf. L. VIllanova, Causalidade e Relação no Direito, cit., p. 114; G. LuMiA, Elementos da Teoria e Ideologia do Direito cit., p.99.

283 Cf. M. BernaRDES DE Mello, Teoria do Fato Jurídico - Plano da Eficácia cit., p. 168.

284 Cf. M. Bernardes De Mello, Teoria do Fato Jurídico - Plano da Eficácia cit., p. 169.

285 Cf. L. Vilanova, Causalidade e Relação no Direito, cit., p. 116 e ss. Contra, P. Perlingieri (Perfis do Direito Civil: Introdução ao Direito Civil Constitucional, trad. port. Maria Cristina De Cico. $3^{\mathrm{a}}$ ed., Rio de Janeiro, Renovar, 2007, p. 115), para quem a relação jurídica não se forma entre sujeitos, mas entre o que 
relação jurídica a atribuição a um sujeito, como efeito de fato jurídico, de uma posição jurídica subjetiva ativa sobre um objeto e a atribuição a outro sujeito de uma correlata posição jurídica subjetiva passiva sobre o mesmo objeto ${ }^{286}$. O ativo e passivo são qualificadores dos interesses sobre o objeto, dizendo quem é titular de interesse subordinante (= ativo) e quem é titular de interesse subordinado (= passivo). Como efeito de fato jurídico, a relação jurídica não precisa, necessariamente, de uma relação social como substrato. Há relações sociais que compõem o suporte fático de norma jurídica, sendo juridicizadas como fatos jurídicos cuja eficácia é a constituição de uma relação jurídica, enquanto existem relações que são criadas exclusivamente no mundo jurídico como efeitos de fatos jurídicos, sem a verificação de qualquer relação social prévia ${ }^{287}$.

Para que se possa falar em relação jurídica, devem ser verificados quatro elementos básicos $^{288}$ : (1) sujeitos (pelo menos dois); (2) objeto; (3) fato jurídico gerador; e (4) garantia. Dos sujeitos, objeto e fato jurídico já foi tratado sumariamente acima, faltando comentar a questão da garantia. $\mathrm{Na}$ medida em que a técnica da relação jurídica visa à ordenação e satisfação de interesses, é preciso que o ordenamento jurídico traga um reforço, uma tutela satisfativa do interesse protegido. Esta garantia se dá pela ação de direito material, o poder agir modificando a esfera jurídica do sujeito passivo com a finalidade de satisfação do interesse ${ }^{289}$. Sempre que uma posição jurídica subjetiva ativa consubstanciada em um poder exigir (= pretensão) for violada, nasce ao titular uma ação, de direito material, para perseguir a satisfação do seu interesse próprio. Entretanto, como o Estado monopoliza a coação institucionalizada, vedando a autotutela, este poder agir, esta ação, deve ser exercitada em juízo, pela proposição da "ação" de direito processual.

ele denomina de "situação jurídica". O conceito de "situação jurídica" adotado pelo autor corresponde à posição jurídica subjetiva proposta por A. TOMASETTI JR., Teoria Geral do Direito Privado, mimeo, 2004.

286 CF. A. TomasetTi JR., Teoria Geral do Direito Privado, mimeo, 2004.

287 Cf. M. Bernardes De Mello, Teoria do Fato Jurídico - Plano da Eficácia cit., p. 169; G. LuMIA, Elementos da Teoria e Ideologia do Direito cit., p. 100; L. VILANOVA, Causalidade e Relação no Direito cit., p. 123. Sem razão, M. A. Domingues AndRADE, Teoria Geral da Relação Jurídica, vol. I, Coimbra, Almedina, 2003, p. 2; A. von TuHR, Derecho civil - Teoría General del Derecho Civil Alemán, trad. esp. Tito Ravá, vol. I, t. I, Madrid, Marcial Pons, 1999, p. 127.

288 M. A. Domingues DE ANDRADE, Teoria geral da relação jurídica, v. I, Coimbra, Almedina, 2003, p. 19.

289 O elemento garantia ficava expresso no antigo artigo 75 do Código Civil de 1916, que prescrevia: "A todo direito corresponde uma ação, que o assegura". Comentando o dispositivo, Clóvis BEVILAQUA explica que a ação é o direito em seu momento defensivo (Código Civil dos Estados Unidos do Brasil, v. 1, $11^{a}$ ed., Rio de Janeiro, Paulo de Azevedo, 1958, p. 255). Se a ação é um "momento do direito" e o direito é determinado no âmbito material, a ação só pode ser conceito de direito material e jamais de direito processual. A grande maioria dos autores pátrios, infelizmente, não compreendeu esta lógica e insistiu que o artigo 75 tratava da "ação" de direito processual, o que levou à inexistência de um dispositivo semelhante no Código Civil de 2002. A ação de direito material como garantia da relação jurídica continua presente no ordenamento jurídico, ainda que não mais expressa como anteriormente. 
Interessa verificar as posições jurídicas subjetivas que são atribuídas aos sujeitos em relação jurídica. A relação jurídica é uma técnica para administração de interesses definindo o interesse subordinante e o interesse subordinado sobre um objeto. O sujeito titular do interesse subordinante figura no polo ativo da relação jurídica (= sujeito ativo), sendo titular de posições jurídicas subjetivas ativas. O sujeito titular do interesse subordinado figura no polo passivo da relação (= sujeito passivo), sendo-lhe imputadas posições jurídicas subjetivas passivas. A posição jurídica do sujeito ativo é correlativa à posição jurídica subjetiva do sujeito passivo; são posições jurídicas de sentidos opostos ${ }^{290}$.

Sistematicamente, seguindo proposta de G. LUMIA ${ }^{291}$, com base em W. N. HOHFELD $^{292}$, e reelaborada por A. TOMASETTI JR. ${ }^{293}$, as posições jurídicas subjetivas elementares a partir da incidência de normas primárias ou normas secundárias ${ }^{294}$ podem ser identificadas por correlação e negação, conforme tabela a seguir. As linhas de cima representam as posições jurídicas subjetivas elementares ativas e as debaixo as posições jurídicas subjetivas elementares passivas. As setas pontilhadas indicam as relações de negação e as setas normais as relações de correlação entre as posições jurídicas subjetivas.
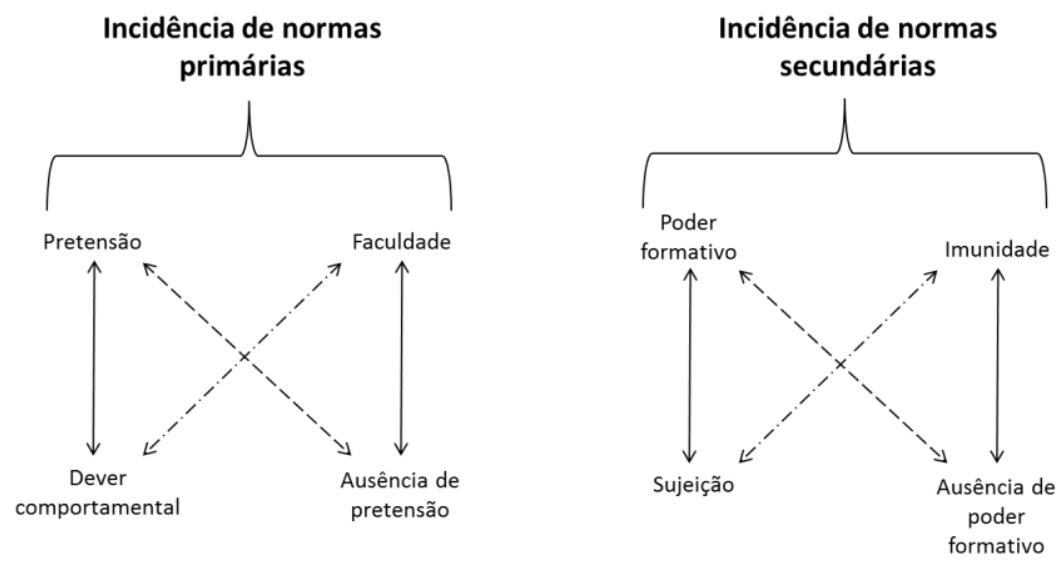

290 Ao contrário do que defende H. KELSEN (Teoria pura do direito. Trad. port. João Baptista Machado. São Paulo: Martins Fontes, 2003, p. 143), a posição jurídica subjetiva ativa não é um mero reflexo da posição jurídica subjetiva passiva. Para que a posição jurídica ativa seja considerada reflexo da posição jurídica subjetiva passiva elas devem ter idêntica intensidade. Entretanto, quando focamos a propriedade percebemos que a intensidade do lado ativo é muito maior, porque a posição jurídica subjetiva passiva é "pulverizada" entre todos os sujeitos (F. C. PonTES DE MIRANDA, Tratado das ações, cit., $\S 4^{\circ}$, n. 3 ).

291 Cf. G. LUMIA, Elementos da teoria e ideologia do direito cit., p. 107.

292 Cf. W. N. HoHFELD, Fundamentals Legal Conceptions as Applied in Judicial Reasoning, New Haven, Yale, 1919, pp. 23 e ss.

293 Cf. A. TOMASETti JR., Teoria Geral do Direito Privado, mimeo, 2004.

294 A exposição que segue é pautada no estudo de G. LuMIA, Elementos da Teoria e Ideologia do Direito cit. p. 105 e ss. A respeito da distinção entre normas primárias e secundárias, cf. HART, Hebert L. A. O Conceito de Direito, trad. port. A. Ribeiro Mendes. $4^{\mathrm{a}}$ ed., Lisboa, Fundação Calouste Gulbenkian, 2005, pp. 89 e ss. 
Portanto, quando uma norma primária confere a um sujeito o poder exigir certo comportamento de outrem, ela atribui ao sujeito ativo uma pretensão (= poder exigir) e ao sujeito passivo um dever comportamental. Pretensão e dever comportamental são posições jurídicas correlatas, não há uma sem a outra. Ao par pretensão / dever comportamental é somado outro, identificado por negação ao primeiro: quando um sujeito não pode exigir uma conduta de outrem significa que a ele há ausência de pretensão, enquanto ao outro há uma faculdade. A incidência de normas primárias gera, no polo ativo, uma pretensão e uma faculdade e no polo passivo um dever comportamental e uma ausência de pretensão.

A incidência de normas secundárias confere ao titular um poder de constituir, modificar ou extinguir relações jurídicas ${ }^{295}$. Como uma relação jurídica precisa sempre de outro sujeito, este é titular de uma posição jurídica de sujeição: ele não pode fazer nada e não deve fazer nada, porque sua esfera jurídica está sujeita a ser modificada (pela criação, modificação e extinção de relações jurídicas) tão-somente pelo exercício do poder formativo. Se um sujeito não é titular do poder formativo de modificar esfera jurídica de outrem há ausência de poder formativo. À ausência de poder formativo de um corresponde uma imunidade de outro. Resumidamente, as posições jurídicas subjetivas elementares ativas oriundas da incidência de normas secundárias são o poder formativo e a imunidade, e as posições jurídicas subjetivas passivas são a sujeição e ausência de poder formativo.

O ordenamento jurídico atribui as posições jurídicas elementares nas mais diversas combinações, criando posições jurídicas subjetivas complexas. A posição jurídica complexa é um conceito

\footnotetext{
"unitário (e unificador) de situações [rectius: posições] jurídicas elementares: isso indica um conjunto de faculdades, pretensões, poderes [formativos] e imunidades que se encontram em um estado de habitual e constante ligação, e que são inerentes a um determinado sujeito em relação a um determinado objeto $^{, 296}$.
}

295 Este poder recebeu o nome na Alemanha de Gestaltungsrecht, expressão que já foi traduzida como direito potestativo, direito conformativo e direito formativo. Consoante proposta terminológica de A. TOMASETTI JR (Teoria Geral do Direito Privado, mimeo, São Paulo, 2004), é mais correto denominar esta posição jurídica subjetiva elementar de poder formativo, para frisar (1) sua aptidão de formar e conformar relações jurídicas e (2) o fato de ser uma posição jurídica subjetiva ativa elementar.

296 Cf. G. Lumia, Elementos da Teoria e Ideologia do Direito cit., p. 107. 
A utilização da posição jurídica subjetiva complexa tem o condão de servir como um instrumento para o raciocínio, sintetizando uma infindável quantidade de posições jurídicas elementares que são atribuídas a um sujeito. É uma fórmula de economia mental. Por isso, não é necessário que as posições jurídicas elementares nasçam todas no mesmo instante. Em um contrato de compra-e-venda que se fixa um termo para o pagamento do preço pelo comprador o crédito do vendedor à prestação de dar o dinheiro existe desde a celebração do contrato. Ao mesmo tempo, o comprador já deve a prestação de dar o dinheiro. As posições jurídicas subjetivas complexas ativa (= crédito) e passiva (= débito) já existem, podendo ser objeto de disposição pelas partes (= exercício de poder formativo). Entretanto, o vendedor ainda não pode exigir a prestação, pois seu crédito carece de pretensão (= poder exigir). $\mathrm{Na}$ data do vencimento, a prestação passa a ser exigível, nascendo ao vendedor a pretensão e ao comprador o dever comportamental ${ }^{297}$.

A posição jurídica complexa mais importante é o direito subjetivo, conceituado como o poder conferido pelo ordenamento jurídico ao um sujeito para que este persiga um interesse próprio de acordo com sua decisão. Não pode ser confundido com o poder funcional, isto é, o poder conferido pelo ordenamento jurídico a um sujeito para perseguir interesse de outrem e que, por isso, deve ser exercido de maneira adequada sob pena de suspensão ou perda da posição jurídica. Não se confunde também com o ônus, posição jurídica subjetiva ativa complexa que impõe uma conduta ao titular, conduta esta que não pode ser exigida por ninguém, para a obtenção de um resultado. $\mathrm{O}$ ordenamento jurídico prescreve a modalidade de ação que deve ser observada para o sujeito atingir um resultado vantajoso.

Com base nas considerações metodológicas construídas nesta seção, será será possível entrar na análise concreta da classificação e qualificação do contrato de participação em grupo de consórcio. 


\section{CLASSIFICAÇÃO E QUALIFICAÇÃO DO CONTRATO DE PARTICIPAÇÃO EM GRUPO DE CONSÓRCIO}

O objeto desta seção consiste na análise da classificação e qualificação do contrato de participação em grupo de consórcio a partir da determinação de seu lugar no esquema global do ordenamento jurídico e na sua comparação, dentro da visão esquemática, com figuras afins, logrando traçar os contornos daquilo que aproxima ou afasta o contrato de participação em grupo de consórcio dessas figuras ${ }^{298}$.

É preciso advertir, desde logo, que a tarefa de classificar um contrato não pode ser confundida com a empreitada de qualifica-lo, pois a qualificação envolve "um juízo predicativo que tem como objecto um contrato concretamente celebrado e que tem como conteúdo a correspondência de um contrato a um ou mais tipos, bem como o grau e o modo dessa correspondência" ${ }^{299}$. Por outro lado, classificar um contrato envolve um juízo de sua pertinência a determinado grupo contratual, sendo os grupos repartidos com base na verificação ou ocorrência de certas características ou qualidades adotadas como critérios distintivos $^{300}$. Assim, qualificar um contrato significa identificar se determinado contrato é um contrato de sociedade ou um contrato de compra-e-venda, a partir de um pensamento tipológico dos tipos enquanto modelos regulatórios de sentido próprio e imanente, enquanto classificar esse mesmo contrato consiste em considera-lo comutativo ou aleatório, gratuito ou oneroso, de escopo comum ou de escambo.

\subsection{Noções gerais do contrato de participação em grupo de consórcio}

Por meio da integração das normas enunciadas no caput do art. $10^{301}$ e no art. $2 .^{0302}$ da Lei n. ${ }^{\circ} 11.795 / 08$, é possível depreender o conceito legal de contrato de participação em

\footnotetext{
298 Cf. A. JUNQUEIRA DE AZEVEDO, (Parecer) Natureza Jurídica do Contrato de Consórcio (sinalagma indireto). Onerosidade excessiva em contrato de consórcio. Resolução parcial do contrato, in Novos Estudos e Pareceres de Direito Privado, São Paulo, Saraiva, 2009, p. 351.

299 Cf. Pedro Pais de Vasconcelos, Contratos Atípicos, 2. a ed., Coimbra, Almedina, 2009, p. 166.

300 Cf. Pedro Pais de VASCONCElos, Contratos Atípicos cit,, p. 167.

301 “Art. 10. O contrato de participação em grupo de consórcio, por adesão, é o instrumento plurilateral de natureza associativa cujo escopo é a constituição de fundo pecuniário para as finalidades previstas no art. $2^{\underline{\underline{o}} \text { '? }}$.

“Art. $2^{\underline{0}}$ Consórcio é a reunião de pessoas naturais e jurídicas em grupo, com prazo de duração e número de cotas previamente determinados, promovida por administradora de consórcio, com a finalidade de propiciar a seus integrantes, de forma isonômica, a aquisição de bens ou serviços, por meio de autofinanciamento".
} 
grupo de consórcio como "instrumento plurilateral de natureza associativa cujo escopo é a constituição de fundo pecuniário para propiciar a seus integrantes, de forma isonômica, a aquisição de bens ou serviços, por meio de autofinanciamento". Um dos objetivos claros do legislador foi afastar qualquer dúvida a respeito do processo de formação do contrato de participação em grupo de consórcio, pois todas as referências legais ao contrato acompanham a expressão "por adesão".

A Lei n. ${ }^{\circ} 11.795 / 08$ também tratou de enunciar abstratamente a eficácia típica do contrato de participação em grupo de consórcio, a constituição de relações jurídicas obrigacionais entre os consorciados e entre os consorciados e a sociedade administradora de grupos de consórcio. Por força da existência de relações jurídicas entre a administradora e os consorciados, a sociedade administradora do grupo de consórcio deve, necessariamente, figurar no contrato de participação no grupo na qualidade de gestora de negócios do grupo e de mandatária de seus interesses e direitos. (art. 5.,$\S 1 .^{\mathrm{o} 303}$ ). Ademais, o diploma legal trouxe um viés finalístico-funcional, uma declaração de princípio, orientadora da análise, da interpretação e da compreensão das relações jurídicas creditícias: propiciar a todos os consorciados igual condição de acesso ao mercado de consumo de bens ou de serviços (art. 10, $\S 11^{{ }^{304}}$ ). É exatamente este caráter finalístico-funcional que deve ser levado em conta pela sociedade administradora do grupo de consórcio ao autorizar ou não o exercício do poder de disposição pelo consorciado de suas posições jurídicas subjetivas ativas e passivas, simples e complexas, como um todo (art. 13 da Lei n. $\left.{ }^{\text {o }} 11.795 / 08^{305}\right)$.

Apesar de não disciplinar pormenorizadamente o processo de formação do contrato de participação de grupo de consórcio, aparentemente uma posição consciente em face da complexidade do fenômeno social e da impossibilidade de retratá-lo fidedignamente na linguagem esquemática das proposições jurídicas ${ }^{306}$, a Lei n. ${ }^{\circ} 11.795 / 08$ trata da proposta de participação no grupo de consórcio, o instrumento por meio do qual o interessado

303 "Art. 5."

$\S 1^{0}$ A administradora de consórcio deve figurar no contrato de participação em grupo de consórcio, por adesão, na qualidade de gestora dos negócios dos grupos e de mandatária de seus interesses e direitos".

304 "Art. 10.

$\S 1^{0}$ O contrato de participação em grupo de consórcio, por adesão, criará vínculos obrigacionais entre os consorciados, e destes com a administradora, para proporcionar a todos igual condição de acesso ao mercado de consumo de bens ou serviços".

305 "Art. 13. Os direitos e obrigações decorrentes do contrato de participação em grupo de consórcio, por adesão, poderão ser transferidos a terceiros, mediante prévia anuência da administradora".

306 Conforme discutido neste estudo, a expressão "proposição jurídica" é empregada como sinônimo de norma jurídica, no sentido de proposição prescritiva pertencente a um sistema social normativo complexo caracterizado por normas primárias e secundárias, norma jurídica. 
solicita sua participação no grupo de consórcio, participação esta que dependerá da aprovação da sociedade administradora do grupo. De acordo com dicção legal, tal aprovação é dotada de eficácia fortíssima, transformando (ou convertendo) a proposta de participação no próprio contrato de participação em grupo de consórcio (art. 10, $§ 3{ }^{\mathrm{o} 307}$ ). Embora a proposta de participação seja convertida no contrato de participação no grupo de consórcio pela aprovação da sociedade administradora de grupos de consórcio, o contrato somente será considerado aperfeiçoado após a adesão de um número suficiente de sujeitos para assegurar a viabilidade econômico-financeira do grupo e a constituição do grupo for aprovada pela maioria dos aderentes em assembleia geral de constituição (Lei n. ${ }^{\circ}$ 11.795/08, art. 10, § 4. ${ }^{\mathrm{o}^{308}}$; art. $16^{309}$ ).

Logrando facilitar a obtenção dos recursos necessários para a formação do fundo comum, o instrumento particular de contrato de participação em grupo de consórcio é considerado título executivo extrajudicial, conferindo liquidez e certeza aos diversos créditos decorrentes do contrato e permitindo o ajuizamento de "ação" de execução em caso de inadimplemento por parte dos consorciados dos deveres e obrigações assumidos (art. 10, § 6. ${ }^{\circ}$ da Lei $11.795 / 08^{310}$ ).

A dinâmica consorcial exige que o contrato de participação em grupo de consórcio seja referenciado em bem móvel, em bem imóvel, incluindo no âmbito de empreendimento imobiliário, ou em serviço, consoante o objeto para a aplicação dos recursos captados no fundo pecuniário (art. 12 da Lei n. ${ }^{\circ} 11.795 / 08^{311}$ ). Nesse sentido, a celebração do contrato de participação no grupo de consórcio atribui para cada consorciado uma cota numericamente identificada e nela caracterizada o bem a ser comprado ou o serviço a ser

307 "Art. 10.

$\S 3^{\mathrm{o}}$ A proposta de participação é o instrumento pelo qual o interessado formaliza seu pedido de

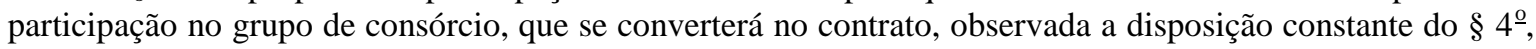
se aprovada pela administradora".

"Art. 10.

$\S 4^{\circ} \mathrm{O}$ contrato de participação em grupo de consórcio aperfeiçoar-se-á na data de constituição do grupo, observado o art. 16".

309 "Art. 16. Considera-se constituído o grupo de consórcio com a realização da primeira assembléia, que será designada pela administradora de consórcio quando houver adesões em número e condições suficientes para assegurar a viabilidade econômico-financeira do empreendimento".

310 "Art. 10.

$\S 6^{\circ} \mathrm{O}$ contrato de participação em grupo de consórcio, por adesão, de consorciado contemplado é título executivo extrajudicial".

311 “Art. 12. O contrato de participação em grupo de consórcio, por adesão, poderá ter como referência bem móvel, imóvel ou serviço de qualquer natureza.

Parágrafo único. O contrato de grupo para a aquisição de bem imóvel poderá estabelecer a aquisição de imóvel em empreendimento imobiliário”. 
contratado com os recursos do fundo pecuniário (art. 11 da Lei n. ${ }^{\circ} 11.795 / 08^{312}$ ). Atribui-se à cota a qualidade de bem móvel, visto que ela pode ser cedida, desde que com anuência da administradora, e adquirida pela própria sociedade administradora do grupo ou partes relacionadas, que, no entanto, somente concorrerá aos sorteios após a contemplação de todos os demais consorciados (art. 15 da Lei n. ${ }^{\circ} 11.795 / 08^{313}$ ).

$\mathrm{Na}$ análise do contrato de participação em grupo de consórcio, que de acordo com a dicção legal, gera relações obrigacionais entre os consorciados e entre os consorciados e a sociedade administradora, a primeira e principal discussão consiste na identificação de quem são as partes contratuais, pois a partir da definição das partes é possível discernir a estrutura do contrato de participação no grupo de consórcio.

Com base na busca pelas partes contratuais, a primeira corrente de autores que se debruçou sobre a estrutura do contrato de participação no grupo de consórcio focou sua atenção na atuação da sociedade administradora de grupos de consórcios, pois é ela quem toma a iniciativa de analisar a viabilidade do consórcio, elaborar o modelo de contrato de participação no grupo e o regulamento interno do grupo de consórcio, fazer os esforços de publicidade e de comercialização das cotas do grupo. Nesse sentido, os signatários dessa corrente sustentam que o emprego das expressões plurilateral e associativo pela Lei 11.795/08 é equivocado, pois o contrato de participação no grupo de consórcio não passa de um negócio jurídico bilateral celebrado entre a sociedade administradora e cada um dos consorciados individualmente, conforme expresso por F. FERNANDES RIBEIRO MAIA:

"O contrato de participação em grupo de consorciados, enfim, nada mais é do
que o instrumento que formaliza a prestação do serviço de gestão e custódia da
administradora em favor do consorciado, bem como o mandato que é conferido à

312 “Art. 11. O contrato de participação em grupo de consórcio, por adesão, implicará atribuição de uma cota de participação no grupo, numericamente identificada, nela caracterizada o bem ou serviço".

313 "Art. 15. A participação de um mesmo consorciado em um grupo de consórcio, para os grupos constituídos a partir da edição desta Lei, fica limitada ao percentual de cotas, a ser fixado pelo Banco Central do Brasil.

$\S 1^{\underline{o}}$ A administradora de consórcio pode adquirir cotas de grupo de consórcio, inclusive sob sua administração.

$\S 2^{\underline{0}}$ A administradora de consórcio, em qualquer hipótese, somente poderá concorrer a sorteio ou lance após a contemplação de todos os demais consorciados.

$\S 3^{\mathrm{o}} \mathrm{O}$ disposto nos $\S \S 1^{\mathrm{o}}$ e $2^{\underline{\mathrm{o}}}$ aplica-se, inclusive:

I - aos administradores e pessoas com função de gestão na administradora;

II - aos administradores e pessoas com função de gestão em empresas coligadas, controladas ou controladoras da administradora;

III - às empresas coligadas, controladas ou controladoras da administradora.

$\S 4^{\circ}$ O percentual referido no caput aplica-se cumulativamente às pessoas relacionadas nos $\S \S 1^{\circ}$ a $3^{\circ}$ " . 
administradora. Além disso, é o título que permite a participação e ingresso no grupo de consorciados" ${ }^{314}$.

Compartilham dessa visão A. M. DE SousA FigueIREdo ${ }^{315}$ e também C. HenRiQue ABRÃO, para quem o contrato de participação em grupo de consórcio é o "contato de adesão pactutado entre os consorciado e a administradora, solene, oneroso, existentes obrigações recíprocas, de duração limitada, e com especificidade no seu propósito ${ }^{316 " .}$ Analisando o fenômeno pela lente do Direito do Consumidor, B. MIRAGEM igualmente enxerga no contrato de participação em grupo de consórcio um contrato por adesão celebrado entre a sociedade administradora do grupo e o consorciado, consistindo em modelo de contrato de outorga de crédito ${ }^{317}$ por meio do qual a administradora assume o papel de fornecedora de serviços financeiros tendentes a viabilizar a compra do bem ou a contratação dos serviços ${ }^{318}$.

Sem dúvida, a grande vantagem de considerar o contrato de participação em grupo de consórcio como um mero contrato por adesão celebrado única e exclusivamente entre o consorciado individualmente e a sociedade administradora do grupo de consórcio é a familiaridade do modelo de contratos bilaterais de escambo, gerando uma relação jurídica de direito obrigacional de prestações correspectivas, na qual uma prestação é a causa da outra. Também torna muito simples apontar a incidência do Código de Defesa do Consumidor, visto existir apenas uma única relação jurídica entre o consorciado de um lado e a administradora do grupo de outro, evidenciando o caráter de consumidor e de fornecedor.

Não obstante, a simplicidade da ideia de um contrato por adesão concluído entre administradora e consorciado adquire elevado grau de complexidade e abstração ao tentar explicar a formação do grupo de consórcios, definido pela lei como "sociedade não personificada constituída por consorciados" com a finalidade de "propiciar a seus integrantes, de forma isonômica, a aquisição de bens ou serviços, por meio de autofinanciamento" (art. 3. ${ }^{\circ}$ caput $^{319} \mathrm{c} / \mathrm{c}$ art. $2 .^{{ }^{320}}$ da Lei n. $\left.{ }^{\circ} 11.795 / 08\right)$. Como a teoria

$314 \quad$ O Sistema de Consórcio Financeiro na Lei 11.795/2008, in Revista de Direito Bancário e do Mercado de Capitais, vol. 47, Jan., 2010, p. 66 e ss.

315 Cf. $A B C$ do Consórcio - Teoria e Prática, 5. a ed., rev. e atual., Curitiba, Juruá, 2009, p. 35.

316 Do consórcio, Rio de Janeiro, GZ, 2010, p. 5.

317 Sobre os contratos de crédito, ver C. LiMA MARQuEs, Os Contratos de Crédito na Legislação Brasileira de Proteção do Consumidor, Revista de Direito do Consumidor, vol. 18, Abr., 1996, p. 53e ss.

318 Curso de Direito do Consumidor, 4. ${ }^{\mathrm{a}}$ ed., rev., atual. e ampl., São Paulo, Revista dos Tribunais, p. 442.

319 “Art. $3^{\circ}$ Grupo de consórcio é uma sociedade não personificada constituída por consorciados para os fins estabelecidos no art. $2^{\mathrm{o}}$ ". 
repousa na existência de contrato bilateral entre consorciado e administradora, o nascimento do grupo de consórcio decorre da realidade fática, um vínculo acidental reconhecido pelo ordenamento jurídico em razão da comunhão de sortes entre os consorciados, disciplinado como sociedade de fato ${ }^{321}$, como associação de fato ${ }^{322}$ ou uma mera reunião eventual e secundária dos consorciados, carecendo de estabilidade e organização suficiente para a sua institucionalização ${ }^{323}$.

A segundo corrente segue o conceito legal e vislumbra no contrato de participação em grupo de consórcio um contrato organizacional ou de colaboração (associativo) celebrado entre os consorciados para o atingimento de um fim comum: a compra de determinado bem ou a contratação de certo serviço ${ }^{324}$, consoante pode ser resumido nas palavras de D. ORFALE GIACOMINI:

\begin{abstract}
"O consórcio é um contrato multilateral em que as partes atuam conjuntamente para alcançar objetivo comum que é a formação do fundo comum apto à aquisição e contemplação de idêntica espécie de bem para todos os integrantes do grupo. Existe reciprocidade de direitos e obrigações entre os consorciados, para que o objetivo do grupo, que é a entrega do bem, seja satisfeito a cada um de seus integrantes" ${ }^{325}$.
\end{abstract}

A teoria do contrato de participação em grupo de consórcio como contrato associativo possui o inegável mérito de atentar para o fenômeno da constituição do grupo de consórcio, considerado pela Lei n. ${ }^{\circ}$ 11.795/08, ao lado do conceito de consórcio e de consorciado, um conceito fundamental para a compreensão, disciplina, estruturação e funcionamento prático do sistema de consórcios. Nesse sentido, antes do advento da Lei n. ${ }^{\circ}$ 11.795/08, S. CAPANEMA DE SouZA reconhecia o caráter associativo do contrato de

\footnotetext{
320 “Art. $2^{2}$ Consórcio é a reunião de pessoas naturais e jurídicas em grupo, com prazo de duração e número de cotas previamente determinados, promovida por administradora de consórcio, com a finalidade de propiciar a seus integrantes, de forma isonômica, a aquisição de bens ou serviços, por meio de autofinanciamento".

$321 \quad$ Cf. A. M. DE Sousa FigueIREDO, ABC do Consórcio cit., p. 33.

322 Cf. O Sistema de Consórcio Financeiro na Lei 11.795/2008, in Revista de Direito Bancário e do Mercado de Capitais, vol. 47, Jan., 2010, p. 66 e ss.

323 Cf. Voto da Min. Nancy Andrighi no Recurso Especial Repetitivo n. ${ }^{\mathbf{1}}$ 1.119.300 - RS, Rel. Min. Luis Felipe Salomão, julgado em 14 de abril de 2010, publicado no DJe de 27 de agosto de 2001.

$324 \quad$ Cf. S CAPANEMA DE SouZA, Responsabilidades Contratuais em face do Ato Declaratório $n .1$ da $S R F / M F$, in ASSOCIAÇÃO BRASILEIRA DE AdVOGAdos, Doutrina em Consórcio, vol. I, t. I, Hermes, 1990, p. 35-36; MARIA Helena Diniz, Tratado teórico e prático dos contratos, vol. IV, 6 a ed., São Paulo, Saraiva, 2006, p. 261; L. Pimentel Nobre - F. Augusto Dadalto Armani, Alguns Comentários sobre a Nova Sistemática dos Consórcios no Brasil, Revista dos Tribunais, vol. 746, Dez., 1997, p. 66; F. DE QUEIROZ BEZERRA CAVAlCANTI, Natureza jurídica do grupo de consórcio, IOB - Repertório de Jurisprudência: Civil, Processual, Penal e Comercial, no. 16, Ago., 1992.

325 A Devolução das Quantias Pagas pelos Consumidores Desistentes e Excluídos dos Contratos de Consórcio à Luz da Lei 11.795/08 e do Código de Defesa do Consumidor, Dissertação de Mestrado, Pontifícia Universidade Católica de São Paulo, 2010, p. 95.
} 
participação no grupo de consórcio, enxergando uma eficácia criadora de um condomínio entre os consorciados (= o grupo de consórcio) e de uma relação jurídica entre o grupo de consórcio e a sociedade administradora do grupo ${ }^{326}$. Por outro lado, a maior parte dos partidários da teoria do contrato associativo, trata o grupo de consórcio como secundário, transferindo a análise para a relação entre o consorciado e a sociedade administradora do grupo, sem explicar exatamente qual o fato jurídico constitutivo dessa relação. Segundo A. D. MALFATTI o contrato de participação em grupo de consórcio possui eficácia dúplice, constituindo relação jurídica de cunho associativo entre os consorciados e inúmeras relações jurídicas entre cada um dos consorciados e a sociedade administradora do grupo de consórcio $^{327}$. Em sua opinião, porém, a relação jurídica primária é a relação entre a administradora e os consorciados, visto que "tudo passa pela atuação da sociedade administradora de consórcio", enquanto os "vínculos entre os consorciados são de natureza acidental e de cunho indireto" com o mero objetivo de "a igualdade entre os consorciados no acesso ao mercado de consumo de produtos e serviços”. Argumenta que, na prática, "nenhum consumidor, de maneira espontânea e perene, busca unir-se a outro para formar um grupo de consórcio, como ocorre nas clássicas figuras jurídicas de associação (art. 53 do CC/2002) ou de sociedade (art. 981 e ss. do CC/2002)", e, portanto, a Lei n." 11.795/08 atribuiu papel fundamental a "uma reunião ocasional dos consumidores ${ }^{\natural 28}$. Em outras palavras, os autores favoráveis à pluralidade do negócio jurídico de participação em grupo de consórcio acabam por chegar a uma encruzilhada, pois ao mesmo tempo em que olham para o fenômeno que chamam de associativo ou de colaboração, consideram mais importante a relação entre os consorciados e administradora do grupo de consórcio do que a relação entre os consorciados.

F. UlHOA COELHO explica que as teorias do contrato por adesão celebrado entre a administradora e os consorciados e do contrato associativo entre consorciados não descrevem satisfatoriamente o fenômeno consorcial pelo simples fato de a Lei n. $^{\text {o }}$ 11.7950/08 não estar preocupada em tipificar o contrato de participação em grupo de consórcio, no sentido de disciplinar de modo completo a relação jurídica por ele constituída. O objeto da Lei n. ${ }^{\circ} 11.795 / 08$ seria, assim, descrever o suporte fático da operação consorcial, transformando o contrato de participação em grupo de consórcio em

\footnotetext{
326 Cf. Responsabilidades Contratuais cit., p. 36.

327 Cf. O Contrato de Consórcio e o Direito do Consumidor, após a Vigência da Lei 11.795/2008, Revista de Direito do Consumidor, $\mathrm{n}^{\circ}$ 70, São Paulo, RT, 2009, pp. 9 e ss.

${ }_{328}$ Cf. O Contrato de Consórcio e o Direito do Consumidor, após a Vigência da Lei 11.795/2008, Revista de Direito do Consumidor, n 70 , São Paulo, RT, 2009, pp. 9 e ss.
} 
contrato misto e atípico, embora juridicamente nominado, que deve ser estudado pela aplicação analógica das normas jurídicas sobre contrato de mandato, contrato de depósito e contrato de sociedade ${ }^{329}$.

\subsection{As várias realidades do contrato}

Meramente pensar na palavra contrato já é suficiente para trazer à mente um fenômeno de múltiplas realidades ou dimensões, começando pela dimensão social, do contrato enquanto mecanismo adotado pelas pessoas em sociedade, como o acordo socialmente vinculativo capaz de definir, de transferir e de extinguir posições sociais e papeis aos diversos atores da vida social, cujo desempenho e aceitação dessas posições e papéis sociais são pautados na confiança e na colaboração entre os atores sociais. Na realidade social, um contrato entre duas pessoas, ou dois atores, é um ato de fé e de confiança que precisa ser protegido na medida em que todo o tecido social é composto, em maior ou menor grau, da linha da fidúcia. Mesmo a divisão do trabalho apontada como o elemento iniciador e responsável pela coesão mecânica da sociedade ainda encontra seu fundamento na expectativa de que cada pessoa compartilhará seu trabalho com o outro. Pode ser uma expectativa decorrente da necessidade, mas é uma expectativa fundada num mínimo de confiança, num pacto expresso ou presumido entre cada ator social. A dimensão social do contrato encontra seu substrato na confiança mútua e na divisão de atribuições e responsabilidades tão necessárias para a vida em sociedade que levou os filósofos iluministas a idealizar o contrato como a pedra fundamental da sociedade. Quando se fala em contrato social como a origem, o fundamento, da vida social, a primeira crítica costumeiramente dirigida a tal proposição é a ausência de consciência e de vontade livre, na medida em que a construção da sociedade impôs-se como necessidade para o frágil ser humano enfrentar as dificuldades e desafios do ambiente. Embora tais críticas estejam alinhadas com as ideias coletivas sobre a origem da ordem social, o emprego da noção de contrato social pelos filósofos não buscava retratar um fato ou a história da civilização, mas era, antes de tudo, um mecanismo de medida racional, uma pedra de toque para analisar a legitimidade dos governos e da construção social. Com base nesta pedra de toque, o valor de determinada sociedade, certo governo ou do Estado deve ser medido e

329 Cf. Curso de Direito Civil, vol. III, 6. ${ }^{a}$ ed., São Paulo, Saraiva, 2013, cap. 39, item 3. 
apreciado pelo grau de êxito ou de fracasso em representar esta sociedade como um efeito de um contrato concluído entre homens racionais ${ }^{330}$.

A par da dimensão social, na verdade como uma subdimensão da realidade social, o contrato é uma realidade econômica, um mecanismo prático de atingimento das mais variadas realidades econômicas por meio da composição de interesses sobre bens econômicos escassos ${ }^{331}$. Economicamente, emprega-se a palavra contrato como um conceito sintetizador de relações econômicas complexas de atribuição e de circulação de bens, cuja escassez torna a titularidade econômica sobre tais bens um critério material e objetivo de riqueza. Os bens não se restringem apenas às coisas, mas a todo e qualquer ente idôneo para satisfazer necessidades do ser humano e por isso dotado de valoração econômica. Pela lógica econômica, é considerado rico o sujeito titular superavitário de bens escassos aptos a satisfazerem as necessidades e desejos de muitas pessoas que, devido à escassez desse bem, são titulares deficitários. O contrato é o instrumento econômico por meio do qual os titulares superavitários transferem seus bens aos titulares deficitários, consiste em um ato material de transferência de riqueza.

Por fim, existe o conceito técnico-jurídico de contrato, autônomo e individualizado em relação ao fato social e ao fato econômico do contrato, construído pelo ordenamento jurídico e pela ciência jurídica com o fim de dotar o pensamento jurídico de expressão técnica de abrangência suficiente para resumir, reelaborar e sintetizar sistematicamente um conjunto de normas jurídicas incidentes sobre a realidade social e sobre a realidade econômica, prescrevendo condutas como obrigatórias, proibidas e permitidas, conferindo aos sujeitos contratuais possibilidades e impondo necessidades ${ }^{332}$. Apesar do conceito jurídico de contrato ser dotado de autonomia, ele não é autossuficiente, não é fechado em si mesmo, pois decorre da incidência das normas jurídicas sobre um fenômeno econômicosocial $^{333}$ e, como tal, implica a interpretação e a representação dessas realidades pelo ordenamento, desempenhando uma função instrumental para o atingimento das diversas

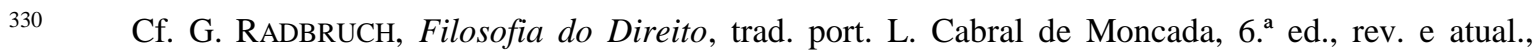
Coimbra, Coimbra, 1997, p. 284.

331 Cf. F. MESsineo, Doctrina General del Contrato, trad. esp. R. O. Fontanarrosa, S. Sentís Melendo, M. Volterra, t. I, Buenos Aireis, Europa-America, 1952, p. 34.

332 Cf. E. Roppo, O Contrato, trad. port. A. Coimbra e M. J. C. Gomes, Coimbra, Almedina, 2009, p. 8.

333 O Direito, como um fenômeno cultural, faz parte da superestrutura da sociedade e, por isso, é condicionado pela estrutura econômico-social decorrente dos modos de produção adotado. É importante notar que a relação entre a estrutura e a superestrutura não é de mão única, pois ao mesmo tempo em que a estrutura condiciona as formas jurídicas ela também é condiciona por essas mesmas formas.
} 
dimensões do fenômeno ${ }^{334}$. Desse modo, apreensão do modelo jurídico dogmático do contrato depende a compreensão dessa realidade econômico-social subjacente à manifestação jurídica do contrato, da correta identificação dos diversos interesses bens econômicos escassos envolvidos e da composição desses interesses por meio do contrato $^{335}$.

\subsection{Modelo dogmático de contrato}

O substrato econômico-social do conceito jurídico de contrato pode ser resumido na ideia de operação econômica ${ }^{336}$; pensar em contratos é pensar, direta ou indiretamente, na confiança socialmente depositada na realização das operações econômicas. Significa, assim, compreender o contrato como a forma ou a veste jurídica para arranjar, adornar e compor os diversos interesses emergentes das operações econômicas e que os agentes econômicos desejam disciplinar, proteger ${ }^{337}$.

Como consequência da identificação da operação econômica como realidade subjacente ao contrato, decorre a constatação de que onde não existe operação econômica não pode existir contrato, pois da mesma forma como as vestimentas não podem sair sozinhas para dar um passeio, necessitando de alguém que as utilize, um contrato não existe no mundo jurídico sem que esteja orientado, formalizando uma operação econômica que é a sua causa e fundamento ${ }^{338}$. Por exemplo, embora o erro substancial seja um defeito que atua no plano da validade dos atos e negócios jurídicos em geral, a análise do erro invalidante de um contrato deve passar, necessariamente, pela constatação de que tal erro é uma expressão jurídica de uma noção falsa da realidade, noção essa fundamental o suficiente para atribuir à operação econômica um significado e um valor concreto diametralmente diferente daquele valor que a parte tinha em mente e utilizou no processo de decisão racional para a conclusão do negócio, o que lhe pode trazer um desbalanceamento dos riscos da operação, criando o risco de prejuízos (e não o prejuízo efetivo) $)^{339}$.

\footnotetext{
334 Para uma visão crítica da origem histórica-ideológica do contrato, ver A. SUPIOT, "Homo juridicus" - Ensaios sobre a Função Antropológica do Direito, trad. port. M. Ermantina de Almeida Prado Galvão, São Paulo, Martins Fontes, 2007 p. 108 e ss.

335 Cf. E. RopPO, O Contrato cit., pp. 8-9; F. MESSINEO, Doctrina General del Contrato cit., pp. 34-36.

336 Cf. E. RopPo, $O$ Contrato cit., p. 8.

337 Cf. F. Messineo, Doctrina General del Contrato cit., p. 34; E. RopPo, O Contrato cit., p. 9.

$338 \quad$ Cf. E. RopPo, $O$ Contrato cit., p. 11.

339 Cf. E. RopPo, $O$ Contrato cit., p. 10.
} 
Afirmar que não pode existir contrato sem operação econômica não pode levar ao equívoco de simplificar a veste jurídica de toda e qualquer operação econômica ao contrato. Existem operações econômicas formalizadas juridicamente por meio de negócios jurídicos unilaterais, como o testamento, enquanto existem operações econômicas que nem sequer recebem uma vestimenta própria do ordenamento jurídico, mas apenas uma coberta básica dentro do poder de autorregramento dos sujeitos. Assim, no modelo dogmático jurídico somente pode existir contrato onde há operação econômica, mas pode existir operação econômica sem haver contrato.

Uma vez que o conceito de operação econômica é o substrato de todo e qualquer contrato, a pergunta a ser respondida consiste em como identificar as operações econômicas. Operações são obras, ações materiais de modificação do mundo pela força ativa do ser humano, que coloca em atividade sua potencia modificadora da realidade, do mundo e da sociedade, permitindo relacionar o conceito de operação com condutas humanas ativas e omissivas orientadas à determinada finalidade. Quanto à qualificação da operação como econômica, E. ROPPO oferece um critério objetivo de análise pautado nos conceitos econômicos de bens escassos e valor econômico, propondo classificar como operação econômica todo ato material de circulação de riqueza, isto é, de transferência potencial ou concreta de riqueza ${ }^{340}$. A despeito de sua grande utilidade prática e razoável facilidade na aplicação, o critério qualificador de E. RoPPO é insuficiente para apanhar a realidade contemporânea na qual o contrato não só funciona de instrumento para a circulação da riqueza, mas também é um veículo de mobilização e desmaterialização dos bens econômicos, assumindo um papel fundamental na geração de riqueza, de utilidades passíveis de valoração econômica ${ }^{341}$. Assim, o critério proposto para identificar a existência de operação econômica, e, portanto, de contrato é a conduta humana orientada à criação ou transferência de bens passíveis de valoração econômica.

Sob a ótica da técnica da relação jurídica, a criação e a transferência de bens passíveis de valoração econômica estão inseridas sistematicamente na disciplina das relações jurídicas patrimoniais, categoria de relação jurídica marcada pela possibilidade de valoração econômica das posições jurídicas subjetivas ativas e passivas, simples e complexas, e consequente expressão pecuniária. São espécies de relações jurídicas patrimoniais as relações jurídicas obrigacionais e as relações jurídicas reais, cujas

\footnotetext{
$340 \quad$ Cf. E. ROPPO, O Contrato cit., p. 13.

341 A. TomasetTi JR., Comentários ao Art. 1. ${ }^{\text {, }}$, in J. DE OliveIRA, Comentários à Lei de Locação de Imóveis Urbanos - Lei n. 8.245, de 18 de outubro de 1991, São Paulo, Saraiva, 1992, p. 7-8.
} 
respectivas posições jurídicas subjetivas integram o setor das esferas jurídicas dos sujeitos denominado de patrimônio, em contraposição ao setor extrapatrimonial e ao setor personalíssimo das esferas jurídicas. Entende-se por patrimônio, então, o conjunto de posições jurídicas subjetivas, ativas e passivas, simples ou complexas, que representa um setor da esfera jurídica de titularidade de um sujeito, passível de valoração econômica e consequente expressão pecuniária ${ }^{342}$. Dessa forma, é possível dizer que há operação econômica para fins do modelo jurídico de contrato sempre que for verificado $o$ deslocamento de posições jurídicas subjetivas de direito obrigacional ou de direito real, ativas ou passivas, simples ou complexas, do patrimônio de um sujeito jurídico para outro, bem como sempre que houver a criação de tais posições jurídicas subjetivas nos patrimônios dos sujeitos jurídicos participantes da operação.

$\mathrm{Na}$ aproximação do modelo dogmático de contrato, identificou-se a operação econômica como o substrato de todo e qualquer contrato, como a função, o porquê concretamente verificado para que possa existir um contrato, visto que os sujeitos jurídicos não celebram um contrato pelo simples prazer de contratar. Por outro lado, apesar de todo contrato conter em seu substrato deslocamento ou criação potencial de posições jurídicas subjetivas patrimoniais, o conceito não é suficiente para captar todas as operações econômicas, como a transferência de posições jurídicas subjetivas por meio do testamento. Como os conceitos jurídicos são culturais, abstratos por natureza, não haveria óbice lógico para a qualificação de um testamento como um contrato se o contrato não representasse também uma dimensão social, relacionada com a relação de confiança criada a partir de um acordo ou de um pacto entre dois ou mais atores sociais. Deveras, a realidade social do contrato, pautada no acordo e na confiança, também conforma o modelo jurídico de contrato, atuando não em seu viés funcional como faz a dimensão econômica, mas no aspecto estrutural, tornando o contrato consequência do acordo entre duas ou mais partes contratuais.

O modelo ${ }^{343}$ dogmático de gradativa captação das realidades econômica e social no conceito jurídico de contrato produziram uma dimensão jurídica estruturada na

342 Cf. A. Tomasetti JR., Comentários cit., p. 7; A. TOMasetti JR., Teoria Geral do Direito Privado, Mimeo, 2004.

343 A metodologia científica reconhece e dedica um papel de extrema importância à utilização de modelos, como, por exemplo, o modelo atômico de Bohr, ou o modelo de dupla hélice do ADN. Funcionalmente, os modelos apresentam-se como representações, tanto de fenômenos como de teorias. No modelo representativo, a ideia de modelo refere-se a um conjunto de características gerais e relativamente estáveis da realidade que são assumidas na construção do raciocínio ou das hipóteses (J. BoGEN - J. Woodward, Saving the Phenomena, Philosophical Review, 97. p. 303-352). Podemos falar, assim, de quatro categorias básicas de modelos: (1) modelos de escala; (2) modelos idealizados; (3) modelos analógicos; e (4) 
participação de pelo menos duas partes atuando de maneira convergente em função de uma operação econômica, conforme explica com clareza A. TOMASETTI JR.:

\begin{abstract}
"Enquanto modelo dogmático, o contrato pode ser conceituado como um negócio jurídico - formado pela congruência entre duas ou mais declarações negociais, contrapostas e convergentes, emitidas por duas ou mais partes, em função de uma operação econômica que tem como eficácia categorial correspondente a autovinculação daquelas partes no sentido de constituir, modificar ou extinguir relação ou relações jurídicas patrimoniais" ${ }^{344}$.
\end{abstract}

De fato, o modelo dogmático trata o contrato como o negócio jurídico bilateral ou plurilateral, formado pela soldagem de dois ou mais negócios jurídicos unilaterais contrapostos e convergentes em função do deslocamento ou criação de posições jurídicas patrimoniais, cuja eficácia típica consiste na constituição, modificação, regulação e extinção de relações jurídicas patrimoniais ${ }^{345}$. Embora a ideia de regulação de relações jurídicas possa ser construída a partir de diferentes doses de constituição, de modificação e de extinção, a regulação apresenta algumas características próprias, podendo ser utilizada pelos sujeitos jurídicos para criar uma moldura, um framework, onde uma ou várias relações jurídicas pode constituir-se, modificar-se ou extinguir-se. Esta moldura de regulação de relações jurídicas patrimoniais é fruto de exercício de profundo poder de autorregramento dos sujeitos conferido pelo ordenamento jurídico e pode ser construído de

modelos fenomenológicos. Os modelos de escala são comuns em nosso cotidiano, funcionando mentalmente a partir da reprodução do objeto de estudo em proporções menores, o que permite uma análise e experimentação mais controlada. Uma maquete utilizada por empresa se demolição para simular uma implosão de um edifício de apartamentos é um exemplo clássico de modelo de escala. Os modelos idealizados são criados por um processo de simplificação e generalização de realidades ou ideias complexas. Não raro, os elementos que formam tal complexidade são tantos e de diversidade tal que podem desviar a atenção para os elementos ou fatores que efetivamente serão analisados. O objetivo de um modelo idealizado, ou modelo ideal, é, assim, reduzir a complexidade, atuando como um atalho para o pensamento, que economiza tempo e energia mental. Um exemplo é o próprio direito subjetivo, que é um conceito englobante de uma série de posições jurídicas subjetivas ativas elementares que são atribuídas a um sujeito que figura no polo ativo de uma relação jurídica. Modelos analógicos, por sua vez, são erigidos sobre as semelhanças e diferenças entre um fenômeno ou ideia e um acontecimento concreto. Trata-se de uma comparação entre características do objeto de estudo e de um objeto próximo do observador. Substitui-se aquilo que é extremamente abstrato e complexo por concretudes usuais e corriqueiras. O modelo da bola de bilhar para a expansão dos gases e o modelo computadorizado para a representação da mente humana são exemplos escolares de modelos analógicos. Os modelos fenomenológicos, por sua vez, são representações das propriedades e funções diretamente observáveis do fenômeno a ser estudado. Muitas vezes, consiste em concreção de uma dada teoria ou lei, o que resulta na exclusão de qualquer elemento indireto.

$344 \quad$ Cf. A. TOMASETTI JR., Comentários cit., p. 6.

345 Contra a posição apresentada no texto, vide E. BETTI, Teoria Geral do Negócio Jurídico, t. II, Coimbra, Coimbra, 1969, p. 198-199, para quem os contratos são negócios jurídicos bilaterais ou plurilaterais de interesses opostos ou paralelos e os acordos são negócios jurídicos plurilaterais e bilaterais nas quais os interesses são convergentes para a busca de um escopo comum, um mecanismo para obter a composição e convergência de interesses contrapostos a partir da colaboração dos sujeitos na perseguição de utilidades comuns. 
maneira concreta, para aplicação em uma única vez, pode ser desenhado abstratamente, para aplicação repetitiva ou para aplicação abstrata ${ }^{346}$.

Importa notar que a noção de contrato enquanto negócio jurídico bilateral ou plurilateral que, em função de uma operação econômica, constitui, modifica, regula e extingue relações jurídicas patrimoniais não se restringe apenas às relações jurídicas creditícias ou obrigacionais, mas abrangem também as relações jurídicas de direito real ${ }^{347}$. Ora, o reconhecimento da dimensão econômica do contrato, de seu papel de vestimenta jurídica das operações econômicas de circulação e criação de riqueza, necessariamente exige observar a existência de contratos de direitos reais, como o famoso acordo de transmissão da propriedade, visto que por mais dinamismo que possa ser conferido pelo direito das obrigações, as relações obrigacionais muitas vezes possuem por escopo a circulação da riqueza e impõem às partes a cooperação necessária para que tal circulação ocorra, mas a circulação apenas aperfeiçoa-se no plano dos direitos reais, com o acordo de transmissão da propriedade ${ }^{348}$.

Após a construção do modelo dogmático de contrato adotado pelo ordenamento jurídico brasileiro, é preciso analisar com mais calma o conceito estruturante e utilizado como critério de classificação dos contratos, de parte contratual.

346 Cf. F. Galgano, Il Negozio Giuridico, Milano, Giuffrè, 2002, p. 36-37.

347 Cf. A. TOMASETti JR., Comentários cit., p. 12. Contra a posição expressa no texto, entendendo que o ordenamento jurídico brasileiro apenas reconhece os contratos de direito obrigacional, ver A. JUNQUEIRA DE AZEVEDo, (Parecer) Natureza Jurídica do Contrato de Consórcio cit., p. 352.

$348 \quad$ Para que a propriedade seja transferida, as partes precisam celebrar um acordo de transmissão cuja eficácia depende da tradição para coisas móveis e do registro para coisas imóveis. Pela própria natureza absoluta dos direitos reais, o acordo de transmissão é um contrato que produz efeitos perante a alteridade. Afinal, o alienante exerce seu poder formativo de disposição contra o alter. Toda a sociedade está sujeita ao exercício do poder de disposição do proprietário. Normalmente, o acordo de transmissão está co-declarado com a decisão de vender e comprar. A decisão é única, mas compõe dois suportes fáticos diferentes: da compra-e-venda e do acordo de transmissão. O acordo de transmissão é causal, mas isso não exclui sua autonomia em relação ao negócio jurídico de direito das obrigações. Um exemplo claro pode ser encontrado nas sociedades por ações. Os contratos de compra-e-venda de ações não transmitem a titularidade; muito menos o Livro de Registro de Ações. É preciso que as partes assinem o termo de transferência no Livro de Registro de Transferência. A assinatura do termo de transferência é o adimplemento da prestação de transferir as ações; a lavratura do termo no livro próprio é forma ao acordo de transmissão das ações, cuja inobservância implica nulidade da transferência. Não se admite, pois, a co-declaração da venda e transferência no mesmo instrumento. Por ser causal, o acordo de transmissão deve fazer menção expressa à causa pressuposta, sob pena de nulidade. A velha formula encontrada nos Livros de Registro de Transferência de Ações pela qual “o acionista A transfere X ações por cessão onerosa a B” é insatisfatória. Esta fórmula significa tão-somente que a transferência é realizada como contraprestação. Não identifica a causa pressuposta (compra-e-venda, permuta, prestação de serviços), mas apenas a situa dentro de um gênero (oneroso / gratuito). Ao fixar uma causa pressuposta a um ato jurídico, procura-se um maior controle de todo o desenrolar de determinada operação econômico. Para permitir tal controle, é preciso que a causa pressuposta esteja totalmente identificada, de maneira que eventual vício no negócio subjacente atingirá o negócio posterior. Um termo de transferência em termos amplos pode ser impugnado por não identificação adequada de sua causa pressuposta. 


\subsection{As partes contratuais}

Conceituar parte contratual no modelo dogmático é uma tarefa aparentemente fácil, mas dotada de complexidade e dificuldade, pois o conceito supera, e muito, o senso comum de parte como todo e qualquer sujeito participante da formação ou da execução de um determinado contrato. Nesse sentido, parte confunde-se com o agente contratual, com o sujeito de situação jurídica emissor do negócio jurídico unilateral de proposta ou com o sujeito emissor do negócio jurídico unilateral de aceitação. Em princípio, o conceito de parte está intimamente relacionado com o sujeito de situação jurídica cuja decisão tomada no exercício de autorregramento preenche o suporte fático de um negócio jurídico patrimonial em função de uma determinada operação econômica; parte é cada sujeito que emite uma declaração negocial orientada a convergir com contra declaração negocial e transforma-se em contrato $^{349}$. Essa noção é tentadora pela sua simplicidade e clareza, mas não explica a situação de um contrato de compra e venda no qual a coisa vendida é comprada e adquirida por vários sujeitos de situações jurídicas, que figuram no contrato como compradores. Olhando para a operação econômica, é inegável haver uma única atuação humana orientada à circulação de riqueza e não tantas operações quantos sejam os condôminos. Se a operação econômica é uma só, então, ou (1) existem tantas partes quantos sejam os vendedores; ou (2) os vários vendedores são figurantes de uma única parte contratual. Do ponto de vista lógico, não existe uma alternativa correta, pois cada ordenamento jurídico pode estruturar o conceito de parte contratual mais condizente com os valores fundantes da respectiva sociedade concretizados no modelo contratual adotado. O ordenamento jurídico brasileiro adotou a alternativa (2), admitindo a figuração de vários sujeitos de situação jurídica dentro do conceito de parte, conforme explica VICENTE RÁO:

\footnotetext{
"Nosso direito e o direito francês adotam o conceito tradicional de parte, assim designado a pessoa ou pessoas que participam de um ato jurídico em concurso com outra, ou outras pessoas (Capitant, Vocab, Jur., verb, partie), ou melhor, o

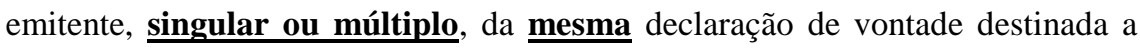
produzir efeitos jurídicos na relação produzida com outra ou outras pessoas" ${ }^{350}$.
} 
A escolha do modelo contratual de múltiplos sujeitos de situações jurídicas no conceito de parte pelo ordenamento jurídico brasileiro ${ }^{351}$, em linha com os ordenamentos jurídicos da Europa continental, traz uma dificuldade prática: identificar de forma prática as partes em um contrato. Nos anos 1920, F. MEssineo, com base em seus estudos da pandectística alemã, propôs um critério praticamente universal para a conceituação de parte, relacionando a parte contratual com um centro autônomo de interesses, que pode ser integrado por apenas um sujeito de situação jurídica na busca por satisfazer o seu interesse ou por dois ou mais sujeitos de situações jurídicas concentrados em um lado do contrato para perseguir interesse ou interesses homogêneos ${ }^{352}$.

A expressão "parte contratual" é empregada como sinônimo da locução "lado contratual", e cada sujeito de situação jurídica titular de interesse que se encontra em um lado do contrato é chamado tecnicamente de figurante. Ao analisar a lateralidade do negócio jurídico, M. BERnARdes DE Mello explica que os figurantes da mesma parte negocial estão posicionados um ao lado de outro e, por esse motivo, suas declarações negociais são paralelas, fundindo-se em um único negócio jurídico unilateral. Por outro lado, figurantes de centros de interesses diferentes estão posicionados um diante do outro, em lados opostos, fazendo com que suas declarações sejam recíprocas e convergentes ${ }^{353}$. Desse modo, para fins de classificação técnica apurada das partes contratuais enquanto centros autônomos de interesses, há partes contratuais unifigurativas, compostas por apenas um sujeito de situações jurídicas, e partes multifigurativas, compostas por dois ou mais sujeitos de situações jurídicas ${ }^{354}$. Além do critério dos figurantes, as partes podem ser classificadas pelo número de interesses aglutinadores, criando uma classificação entre partes simples, compostas por apenas um interesse, e partes complexas, compostas por vários interesses homogêneos ${ }^{355}$. Tais classificações dialogam entre si e permitem identificar cientificamente situações nas quais há partes complexas unifigurativas e partes simples multifigurativas sem correr o risco de baralhamento entre os múltiplos interesses

351 A presença de partes compostas por mais de um sujeito de situação jurídica não é restrita aos contratos, mas faz parte de um modelo dogmático mais amplo envolvendo os atos jurídicos stricto sensu e os negócios jurídicos em geral. As conclusões e os critérios para identificação da parte contratual são igualmente aplicáveis para as partes dos atos e dos negócios jurídicos.

$352 \quad$ Cf. F. Messineo, Doctrina General del Contrato, p. 74; F. GALGANO, Il Negozio Giuridico cit., p. 40; E. Roppo, O Contrato cit., p. 81; A. TomasetTi JR., A Parte Contratual, in M. VIEIRA VON AdAMEK, Temas de Direito Societário e Empresarial Contemporâneos, São Paulo, Malheiros, 2011, p. 757; E. BETTI, Teoria Geral do Negócio Jurídico cit., vol. I, p. 162; M. BERnARdeS DE MELlo, Teoria do Fato Jurídico Plano da Existência cit., p. 235.

$353 \quad$ Cf. Teoria do Fato Jurídico - Plano da Existência cit., p. 235.

354 Cf. A. TOMASETti JR., A Parte Contratual cit., p. 757.

355 Cf. A. TOMASETTI JR., A Parte Contratual cit., p. 761. 
ou sujeitos de relações jurídicas ${ }^{356}$.

Utilizar o critério dos centros de interesse para identificar as partes contratuais também permite traçar as linhas demarcatórias dos efeitos subjetivos dos contratos, tendo em vista o princípio da relatividade dos efeitos contratuais. Em regra, os efeitos dos contratos (e dos atos jurídicos lato sensu) são produzidos na esfera jurídica ou nas esferas jurídicas do sujeito de situações jurídicas ou dos sujeitos de situações jurídicas figurantes da parte. Assim, o princípio da relatividade dos efeitos contratuais pode ser enunciado pelo brocado que o contrato, ou melhor, o ato jurídico é "res inter alios acta, aliis neque nocet neque prodest" ${ }^{357}$. A inexistência na legislação pátria proposição normativa como a enunciada no artigo 1.165 do Code Civile francês ${ }^{358}$ ou no do artigo 1372 do Codice Civile italiano $^{359}$, que prescrevem a relatividade dos efeitos contratuais, não autoriza negar a relatividade dos efeitos dos atos jurídicos com um princípio basilar do direito privado e do direito contratual especificamente ${ }^{360}$.

Analisando o fenômeno da parte contratual no plano da eficácia, em princípio os sujeitos que figuram nas partes contratuais também figuram nos polos ativos ou passivos ou ambos ${ }^{361}$, permitindo relacionar parte com o sujeito de situações jurídicas ou os sujeitos de situações jurídicas a quem são imputadas posições jurídicas subjetivas, ativas ou passivas, identificáveis por negação e correlação das posições jurídicas subjetivas

356 E. BetTI, Teoria Geral do Negócio Jurídico cit., vol. I, p. 162: "Parte é quem, com o negócio, regula um interesse próprio. Por isso, a) se o interesse em jogo é único e idêntico, a parte será única, embora possa ser constituída por várias pessoas [sujeitos de situações jurídicas]. Se, pelo contrário, b) os interesses em jogo são diferentes, encontrar-nos-emos perante duas ou mais partes. [...] O negócio, ou o acto, no primeiro caso (a) será unilateral e referível a uma só parte, embora seja subjectivamente complexo, isto é, composto por várias declarações, bem distintas e provenientes de diversos sujeitos, mas que não se confundem entre si, ainda que sejam coincidentes e visando um conteúdo preceptivo comum e unitário (pense-se no caso da renúncia abdicativa ou constitutiva de servidões, que diversos condóminos façam a respeito da coisa comum). No segundo caso (b), pelo contrário, o negócio, que se desenvolve e conclui entre duas partes, será bilateral'. F. C. PONTES DE MIRANDA, apesar de seguir linha semelhante, critica, com razão, o exemplo fornecido por E. BETTI da constituição das servidões como negócio unilateral, pois, na realidade, cada condômino atua como uma parte independente, exercendo, embora simultaneamente aos demais, os direitos de propriedade de sua titularidade (Tratado de Direito Privado cit., t. III, § 283, n. 1, p. 171)

357 "A coisa pactuada entre os outros, nem aproveita nem beneficia".

358 “Article 1165 Les conventions n'ont d'effet qu'entre les parties contractantes; elles ne nuisent point au tiers, et elles ne lui profitent que dans le cas prévu par l'article 1121".

359 “Art. 1372 Efficacia del contratto

Il contratto ha forza di legge tra le parti. Non può essere sciolto che per mutuo consenso o per cause ammesse dalla legge $(1671,2227)$. Il contratto non produce effetto rispetto ai terzi che nei casi previsti dalla legge (1239, 1300 e seguente, 1411, 1678, 1737)".

360 R. LimOngi FrançA, Autonomia da vontade, in Enciclopédia Saraiva de Direito, vol. IX, São Paulo, Saraiva, 1978, p. 246.

361 Cf. A. TOMASETTI JR., A Parte Contratual cit., p. 761. 
contrapostas, decorrentes do contrato ${ }^{362}$. Nesse sentido, parte contratual é o sujeito de situações jurídicas que figura em um centro autônomo de interesses no momento da celebração do contrato (= parte) e por força de seu interesse, suporta em sua esfera jurídica os efeitos jurídicos de constituição, de modificação, de regulação e de extinção de relações jurídicas produzidos por este contrato ${ }^{363}$. Muitas vezes, porém, determinado sujeito toma parte em um ato jurídico lato sensu, decidindo inclusive seu conteúdo, sem necessariamente ter interesse nos efeitos a serem produzidos, como no caso do procurador, interessado na prática do ato, mas sem interesse imediato em sua eficácia ${ }^{364}$. Para compreender corretamente situações como essa, é preciso distinguir a parte contratual no plano da existência e a parte contratual no plano da eficácia, o que levou E. BETTI a traçar importante distinção quanto ao conceito funcional de parte, denominando de parte em sentido formal "aquele a quem [...] cabe a paternidade do negocio: isto é, aquele a quem deve referir-se, não só a forma do acto - a declaração ou o comportamento - mas também o conteúdo, o preceito do negocio" ${ }^{365}$. Na medida em que à parte em sentido formal imputa-se a decisão que forma e conforma o ato jurídico, o sujeito de situações ou os sujeitos de situações jurídicas figurante da parte em sentido formal assume o papel de agente e, por isso, imputam-se também à parte em sentido formal os requisitos de validade (capacidade, legitimidade, ausência de defeito no ato jurídico) e os fatores de eficácia subjetivos (como a legitimação) ${ }^{366}$. Se existe uma parte em sentido formal, também existe uma parte em sentido material ou substancial, entendida por E. BETTI como o "sujeito em favor de quem a relação deve constituir-se ou desenvolver-se, quer seja ele mesmo a

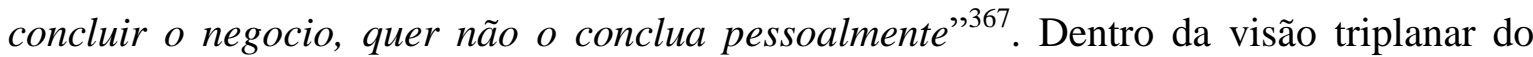
mundo jurídico, a parte em sentido formal atua nos planos da existência e da validade dos fatos jurídicos, enquanto a parte em sentido substancial atua no plano da eficácia, representada por um dos polos da relação jurídica contratual. Como regra geral, a parte em sentido formal e a parte em sentido substancial são idênticas, mas dentro das hipóteses previstas no ordenamento jurídico, como a legitimação para mover a esfera jurídica alheia,

362 Cf. L. DE CAMARgo Penteado, Efeitos contratuais perante terceiros, São Paulo, Quartier Latin, 2007, p. 231.

363 Enquanto o sujeito possui apenas potencialidade de ser sujeito de situação jurídica ele não é parte, contudo, no instante que ele passa a ser um sujeito a quem se imputa, in concreto, situação jurídica, ele deixa de ser mera potencialidade para ser uma parte juridicamente reconhecida e tutelada.

$364 \quad$ O critério é o interesse imediato, porque pode existir um interesse reflexo na eficácia do ato ou negócio. O procurador, por exemplo, tem interesse que o negócio por ele praticado seja eficaz, produzindo os efeitos não em sua esfera jurídica, mas na esfera jurídica do procurado.

365 Teoria Geral do Negócio Jurídico cit., vol. I, p. 158.

366 Cf. A. TOMASETTI JR., A Parte Contratual cit., p. 761

367 Teoria Geral do Negócio Jurídico cit., vol. I, p. 158. 
a parte contratual na existência do contrato pode ser diferente da parte contratual no plano da eficácia.

Em resumo, as partes contratuais correspondem aos centros de interesses autônomos concentrados em cada lado do contrato, onde podem figurar um ou mais sujeitos de situações jurídicas em torno de único interesse ou vários interesses homogêneos. No plano da existência, a parte contratual emite o negócio jurídico unilateral de oferta ou de aceitação necessário para a formação do contrato, devendo realizar-se a análise dos requisitos subjetivos de validade com relação aos sujeitos figurantes da parte, enquanto no plano da eficácia a parte contratual consiste no centro autônomo de interesses polarizados na relação jurídica, correspondendo cada parte a um polo ou lado da relação jurídica contratual. Exceto para fins da verificação dos elementos de existência e dos requisitos de validade, o estudo do contrato e da relação jurídica contratual deve focalizar na parte contratual no plano da eficácia, pois são os figurantes da parte em sentido substancial quem suporta os efeitos do contrato e a quem o fim contratual efetivamente se refere.

\subsection{Formação dos contratos}

Dentro do modelo dogmático adotado, o contrato é considerado um negócio jurídico bilateral ou plurilateral, proveniente da soldagem de dois ou mais negócios jurídicos unilaterais convergentes, emitidos por duas ou mais partes, unifigurativas, multifigurativas, simples ou complexas, em função de uma operação econômica, com o efeito de constituir, modificar, regular ou extinguir relações jurídicas obrigacionais ou relações jurídicas reais. Um ponto fulcral da compreensão da dinâmica contratual, então, passa a ser a compreensão desse processo de soldagem dos vários negócios unilaterais em um negócio jurídico bilateral ou plurilateral contratual ${ }^{368}$.

368 Há autores como F. Messineo (F. MessineO, Doctrina General del Contrato cit., p. 312) e I. Galvão Telles (Manual dos Contratos em Geral, 4. ${ }^{\text {a }}$ ed., Coimbra, Coimbra, p. 246) que negam o caráter negocial da proposta e da aceitação, classificando-as como atos jurídicos que serão fusionados para criar o negócio jurídico. Não obstante, dentro da classificação dos fatos jurídicos adotada, é impossível negar o caráter de exercício de autorregramento privado com escolha de categoria negocial e amplitude de eficácia, visto que não apenas é possível como também é comum a aposição de condições, termos, encargos e outras cláusulas atípicas de regulação da eficácia desses fatos jurídicos. No caso da aceitação, é importante separar a inclusão de condição ou termo ao contrato desejado da aposição de condição ou termo no ato de aceitação. Incluir uma condição suspensiva ou resolutiva para disciplinar a eficácia do contrato a ser celebrado importa 
O negócio jurídico unilateral emitido por uma parte em direção a outra, contendo todos os elementos de existência do contrato desejado ${ }^{369}$, cujo conteúdo consiste na de vinculação ou vinculabilidade do ofertante é denominado de proposta ou oferta ${ }^{370}$ (art. 427 do Código Civil ${ }^{371}$ ). A vinculação ou a vinculabilidade estão relacionados com a exposição da esfera jurídica do ofertante aos efeitos do negócio jurídico unilateral de aceitação da proposta por parte do ofertado, uma vez que, do ponto de vista técnico, a parte ofertante passa a ser titular de uma posição jurídica subjetiva passiva elementar de sujeição enquanto a parte ofertada passa a ser titular de uma posição jurídica subjetiva elementar de modificação da esfera jurídica do ofertante com a constituição da relação jurídica contratual, ou seja, um poder formativo gerador. Se há posição jurídica subjetiva ativa e posição jurídica subjetiva passiva elementar então o ofertante e o ofertado estão colocados um em relação ao outro, evidenciando a existência de relação jurídica entre ofertante e ofertado $^{372}$. Difere a vinculação da vinculabilidade pela existência de uma posição jurídica subjetiva ativa elementar de poder formativo extintivo de titularidade do ofertante, porque nas situações nas quais a oferta é revogável, o ofertante pode, até o momento da aceitação do ofertado, retirar a vox e excluir o negócio jurídico unilateral do plano da existência,

em rejeição da oferta inicial e emissão de contraproposta, pois objetiva alterar o conteúdo eficiacial do contrato. Por outro lado, nada impede que o aceitante aponha uma condição à eficácia, não do contrato, mas da aceitação, como, por exemplo, ela chegar ao conhecimento do ofertante até determinada data em razão da necessidade de a execução do contrato iniciar-se em certo ponto específico no tempo. Apesar de ser situação pouco comum na prática, a mera possibilidade teórica disso acontecer é suficiente para impor a classificação da aceitação, logicamente, como um negócio jurídico unilateral.

$369 \quad$ Cf. I. GALVÃo Telles, Manual dos Contratos em Geral cit., p. 247.

370 Cf. F. C. PONTES DE MIRANDA, Tratado de Direito Privado, t. XXXVIII, 2. a ed., Rio de Janeiro, Borsoi, 1970, § 4.189, n. 1, p. 26: “O que se chama oferta é a primeira manifestação de vontade, a que se há de seguir a aceitação, para que se conclua o negócio jurídico bilateral. Também se costuma chamar proposta à oferta e no Código Civil foi êsse nome o que se empregou".

"Art. 427. A proposta de contrato obriga o proponente, se o contrário não resultar dos termos dela, da natureza do negócio, ou das circunstâncias do caso".

372 M. BeRnARDES DE MELlo (Teoria do Fato Jurídico - Plano da Existência cit., pp. 214-215) nega o caráter relacional, enxergando no fenômeno apenas uma situação jurídica complexa unilateral, pois tanto o poder formativo gerador como a sujeição seriam autônomas, dizendo respeito à apenas uma esfera jurídica. No entendimento do autor, falta a correspectividade característica das relações jurídicas porque como regra ninguém pode modificar a esfera jurídica de outrem, nem mesmo para criar direitos, sem o consentimento do titular dessa esfera jurídica. $\mathrm{O}$ argumento é interessante, mas desconsidera o fato de que ninguém pode modificar a esfera jurídica de outrem, exceto quando o ordenamento jurídico autoriza tal modificação conferindo um poder formativo, gerador, modificativo ou extintivo. A adoção de um modelo negocial e contratual pautado na pontuação da oferta e da aceitação, modelo desenvolvido historicamente para as negociações por correspondência, exige reconhecer tanto ao ofertante como ao ofertado um poder formativo de modificar a esfera jurídica de outrem e, em contrapartida, conferir ao destinatário um poder formativo de constituir a relação jurídica do negócio jurídico ou do contrato. Poder formativo e sujeição são posições jurídicas subjetivas e só existem porque um sujeito está posicionado em relação ao outro, de maneira que não pode existir posição jurídica subjetiva sem relação jurídica. A pergunta a ser respondida em outro local é se referida relação jurídica decorre do negócio jurídico de oferta (=relação jurídica com sujeito passivo determinado) ou se decorre do poder de autorregramento atribuído aos sujeitos em função da relação jurídica fundamental (= relação jurídica com sujeito passivo universal). 
apagando os seus efeitos e excluindo o poder formativo gerador da parte ofertada. Em tais casos nos quais existe um poder formativo extintivo da oferta, fala-se em vinculabilidade do ofertante. Por outro lado, quando a oferta é irrevogável, o ofertante é titular apenas da posição jurídica subjetiva passiva elementar de sujeição e, portanto, verifica-se a vinculação à oferta ${ }^{373}$.

É preciso tomar cuidado para não confundir a oferta revogável com a chamada proposta não vinculativa cada vez mais presente no dia a dia negocial por meio das cartas de intenções, dos memorandos de entendimentos e outras modalidades inseridas nos processos negociais. Conforme o modelo contratual adotado pelo ordenamento jurídico brasileiro, faz parte do núcleo do suporte fático do negócio jurídico unilateral de oferta ou proposta a exposição da esfera jurídica do ofertante ao poder formativo gerador da relação contratual que é efeito final do contrato desejado ${ }^{374}$. Essa exposição ao poder formativo gerador caracteriza a vinculabilidade ou a vinculação necessária para a incidência da norma jurídica sobre referida conduta, trazendo-a para o mundo jurídico como um negócio jurídico unilateral de oferta. Nesse sentido, a chamada "proposta não vinculativa" não contém o elemento vinculação ou o elemento vinculabilidade e por tal motivo não sofre a incidência da norma jurídica disciplinadora da oferta, inexistindo no mundo jurídico como negócio jurídico unilateral de oferta. A revogabilidade pressupõe oferta existente que pode ser desjuridicizada pelo ofertante por exercício de poder formativo extintivo antes da aceitação pelo ofertado. Uma vez aceita a oferta, não cabe mais falar em revogabilididade. Eventual poder de finalizar a relação jurídica contratual será um poder formativo extintivo resolutivo ou resilitivo ou poder formativo modificativo denunciativo no âmbito da relação jurídica contratual já constituída, exercitável apenas em conformidade com as cláusulas do contrato. Falar em "proposta não vinculativa" é uma contradição lógica, pois uma declaração não vinculativa é uma declaração não negocial ou, dependendo das circunstâncias, ainda que sofra a incidência de alguma norma jurídica, não será um negócio jurídico unilateral de oferta. Normalmente, a "proposta não vinculativa” não passa de um

\footnotetext{
373 A diferenciação entre vinculação e vinculabilidade, embora em termos diferentes do adotado no texto, foi proposta por M. Bernardes DE MELlo, Teoria do Fato Jurídico - Plano da Existência cit., pp. 213-215.

374 Cf. F. C. Pontes De MirandA, Tratado de Direito Privado cit., t. XXXVIII, § 4.194, n. 3, p. 48: "Sem que as manifestações de vontade entrem no mundo jurídico não há vinculação, porque a vinculacão já é eficácia do negócio jurídico. Acontece, porém, que a primeira manifestação de vontade já pode vincular. Tal vinculação resulta de negócio jurídico unilateral, a oferta, com que se há de concluir, com a aceitação, o negócio jurídico bilateral ou plurilateral. $\mathrm{O}$ oferente vincula-se por sua oferta e à sua oferta, até que cesse a possibilidade da aceitação, ou à conclusão com os pressupostos necessários".
} 
convite a negociar, estabelecendo os pontos básicos para as discussões entre as partes ${ }^{375}$, podendo, excepcionalmente, conter negócio jurídico unilateral de proposta de contrato de negociação com exclusividade ou de sigilo e confidencialidade. Em tais casos excepcionais, a aceitação do ofertante implica a celebração de um contrato de negociação com exclusividade, um contrato de sigilo e confidencialidade e, em alguns casos, um contrato de negociação por meio do qual as partes passam a ser reciprocamente titulares de direito subjetivo e pretensão a negociar o contrato desejado durante certo prazo. Ainda assim, com relação ao contrato efetivamente desejado pelas partes, a "proposta não vinculativa" continua carecendo de elemento de existência que lhe permita ser considerada como negócio jurídico unilateral de proposta ou oferta.

A decisão unilateral contendo os elementos de existência do contrato desejado como oferta é reconhecida pelo ordenamento jurídico como oferta, "se o contrário não resultar dos termos dela, da natureza do negócio, ou das circunstâncias do caso" (art. 427 do Código Civil), o que significa que existe uma presunção de vinculabilidade ou de vinculação inerente ao conceito de oferta acima discutido. Presume-se que a exteriorização de vontade unilateral contendo todos os elementos de existência de determinado contrato é uma oferta, exceto se a ausência de vinculação ou vinculabilidade for expressa ou decorrer da prática negocial desse tipo de contrato. Eventualmente, pode faltar algum requisito de validade ou fato de eficácia que impeçam a produção do efeito de vinculação ou vinculabilidade, mas o elemento nuclear do suporte fático do negócio jurídico unilateral de oferta foi preenchido e o negócio existe, visto que basta a presença da possibilidade do ofertante ter sua esfera jurídica exposta à aceitação do ofertado, ainda que tal exposição, como efeito da proposta, não venha a se verificar na prática. Ademais, o Código Civil admite a revogação do negócio jurídico unilateral de oferta se o negócio jurídico unilateral revogatório for recebido pelo ofertado antes ou simultaneamente ao recebimento da oferta (art. 428, IV do Código Civil ${ }^{376}$ ), esculpindo como regra geral a vinculação do ofertante após o recebimento do negócio jurídico unilateral de oferta pelo oblato. A situação jurídica de vinculabilidade, decorrente do poder formativo extintivo de revogação da oferta após o recebimento pelo ofertado, também é excepcional e deve estar contar de cláusula expressa

\footnotetext{
375 Cf. I. Galvão Telles, Manual dos Contratos em Geral cit., p. 247.

376 "Art. 428. Deixa de ser obrigatória a proposta:

IV - se, antes dela, ou simultaneamente, chegar ao conhecimento da outra parte a retratação do proponente".
} 
e claramente perceptível do negócio jurídico unilateral de oferta ${ }^{377}$.

Uma vez recebido pelo ofertado o negócio jurídico unilateral de oferta, ele pode (1) aceitar a proposta; (2) rejeitar a proposta; ou (3) propor nova oferta que até pode corresponder com a proposta original com alguma modificação ou restrição ${ }^{378}$. No tocante à aceitação e à rejeição, ambas as espécies podem ser concretizadas de modo expresso, de modo tácito ou pelo silêncio, dependendo das circunstâncias. A aceitação ou rejeição expressa consiste em declaração por meio do qual se utiliza a linguagem (oral, verbal, escrita) e uma língua de aceitação comum entre as partes para tornar clara a decisão de aceitar ou rejeitar ${ }^{379}$. Por sua vez, a aceitação ou rejeição tácita relacionam-se com a manifestação da decisão do ofertado por meio de condutas, positivas ou negativas, condizentes quer com a aceitação quer com a rejeição da proposta (se ofertado vende a outrem a coisa única objeto final da proposta de compra isso significa a rejeição da proposta; lado outro, se toma exteriormente as medidas necessárias para cumprir suas prestações, isso implica a aceitação da proposta), cuja eficácia, porém, depende do ofertante tomar conhecimento dessa conduta manifestadora da decisão dentro do prazo de resposta assinalado ${ }^{380}$. Por sua vez, a completa omissão, o silêncio total e absoluto e não atuação em qualquer sentido importa, em princípio, manifestação de rejeição da oferta. Nas situações nas quais os usos e costumes daquele tipo contratual específico tomam o silêncio como exteriorização de aceitação ou o oferente expressamente informou ao ofertado de que o silêncio interpretar-se-ia como aceitação, o silêncio é tido como manifestação de $\operatorname{aceitação~}^{381}$.

Denomina-se aceitação o negócio jurídico unilateral receptício, logicamente sucessivo à oferta (ainda que aparentemente simultâneo) ${ }^{382}$, por meio do qual o ofertado exerce sua posição jurídica subjetiva ativa elementar de poder formativo constitutivo da

377 F. C. Pontes DE MIRANDA, Tratado de Direito Privado cit., t. XXXVIII, $§ 4.194$, n. 4, p. 48: “A oferta vincula o oferente. Desgraçadamente, nas leis e nos livros de doutrina, por vêzes se emprega 'obrigar' em vez de vincular, ou de 'tornar devedor', como de obrigar stricto sensu. A vinculação, a dívida e a obrigação se confundem. O oferente ainda não deve, a fortiori ainda não é obrigado, mas vinculado fica, exceto se na oferta estabeleceu restrições, ou se a invinculabilidade resulta do tipo mesmo do negócio jurídico, ou de circunstâncias do caso concreto".

378 Cf. K. LARENZ, Derecho de Obligaciones, trad. esp. Jaime Santos Briz, t. II, Madrid, Editorial Revista de Derecho Privado, 1958, p. 86.

379 Cf. F. C. Pontes DE MIRANDA, Tratado de Direito Privado cit., t. XXXVIII, § 4.190, n. 2, p. 28 ; K. LARENZ, Derecho de Obligaciones cit., t. II, pp. 86-87.

$380 \quad$ Cf. F. C. PonTES DE MiRAnDA, Tratado de Direito Privado cit., t. XXXVIII, § 4.190, n. 3, p. 28 ; K. LARENZ, Derecho de Obligaciones cit., t. II, pp. 86-87.

$381 \quad$ Cf. F. C. PONTES DE MIRANDA, Tratado de Direito Privado cit., t. XXXVIII, § 4.190, n. 4, p. 28-29; K. LARENZ, Derecho de Obligaciones cit., t. II, pp. 86-87.

382 Cf. K. LARENZ, Derecho de Obligaciones cit., p. 85. 
relação jurídica contratual, cujo conteúdo eficacial consiste em fundir-se com o negócio jurídico unilateral de oferta para preencher o suporte fático de determinado contrato típico ou de contrato atípico, conforme explicação de F. C. PONTES DE MIRANDA:

\begin{abstract}
"Quando as manifestaçôes de vontade dos figurantes se acordam e entram, como algo de comum, no mundo jurídico, há o negócio jurídico bilateral, ou o negócio jurídico plurílateral. A vínculação é o primeiro efeito do negócio se expôs ao acôrdo (= à entrada no mundo jurídico como ele-jurídico que se concluiu. Houve, porém, provàvelmente, efeito anterior à conclusão, que foi a da manifestação de vontade que o negócio jurídico concluído), ou se fêz, além de exposta, irrevogável"383.
\end{abstract}

Quando a eficácia do negócio jurídico unilateral de aceitação encontra a eficácia do negócio jurídico unilateral de oferta há uma soldagem eficacial e a incidência das normas jurídicas sobre negócio jurídico bilateral ou plurilateral. Como essa soldagem negocial ocorre a partir do encontro dos efeitos dos negócios jurídicos unilaterais de oferta e de aceitação, só haverá a soldagem e a incidência das normas jurídicas quando da recepção da aceitação pelo ofertante. De acordo com o art. 423 do Código Civil ${ }^{384}$, “os contratos [...] tornam-se perfeitos desde que a aceitação é expedida", gerando a falsa impressão de existência de negócio jurídico bilateral ou plurilateral no momento da expedição da aceitação. Trata-se de impressão falsa porque ignora o caráter receptício da aceitação e a soldagem das eficácias da oferta e da aceitação para a formação do negócio jurídico bilateral ou plurilateral. Se o negócio jurídico unilateral de aceitação somente produz efeitos quando da sua recepção pelo ofertante e essa eficácia solda-se com a eficácia do negócio jurídico unilateral de oferta, é ilógico dizer que a soldagem das eficácias ocorra antes da eficácia a ser soldada. Isso fica evidente nas exceções previstas no próprio art. 434, pois o contrato deixa de se tornar perfeito se antes da aceitação ou simultaneamente a ela "chegar ao proponente a retratação do aceitante" (art. 434, I c/c art. 433 do Código Civil $^{385}$ ) ou se a aceitação "não chegar no prazo convencionado" (art. 434, III do Código Civil). Ou o contrato existe desde o momento da expedição da aceitação, mas pode ser

383 F. C. PONTES DE MIRANDA, Tratado de Direito Privado, t. XXXVIII, 2. a ed., Rio de Janeiro, Borsoi, $1972, \S 4.194$, n. 1, p. 47.

384 "Art. 434. Os contratos entre ausentes tornam-se perfeitos desde que a aceitação é expedida, exceto: I - no caso do artigo antecedente;

II - se o proponente se houver comprometido a esperar resposta;

III - se ela não chegar no prazo convencionado".

385 "Art. 433. Considera-se inexistente a aceitação, se antes dela ou com ela chegar ao proponente a retratação do aceitante". 
desconstituído no plano da existência se a revogação da aceitação chegar antes ou simultaneamente à aceitação ou se a recepção da aceitação atrasar, ou o contrato não existe até o momento da recepção da aceitação dentro do prazo e sem qualquer revogação, assumindo-se, que os efeitos do contrato, o nascimento da relação jurídica contratual, retroagem até a data da expedição da aceitação. Ambas as alternativas são viáveis, mas apenas a segunda alternativa conforma-se ao processo de composição do suporte fático do contrato, trazendo menor trauma no mundo jurídico, visto que a retro-operação de efeitos verifica-se apenas no plano da eficácia, sem atacar os fatos no plano da existência.

Eventual negócio jurídico unilateral denominado aceitação, mas contendo modificação de qualquer cláusula ou ponto da oferta não é aceitação, mas uma nova oferta ou contraproposta (art. 431 do Código Civil ${ }^{386}$ ). O modelo dogmático contratual transforma o processo de negociação em um jogo de tênis de ofertas, em vívida ilustração proposta por F. C. PONTES DE MIRANDA:

\footnotetext{
“À oferta ou sucede a aceitação pura e simples, que bilateraliza o negócio jurídico e vincula os figurantes, ou a recusa, ou a aceitação modificativa que não é, própriamente, aceitação, mas sim nova manifestação de vontade, outra oferta, no lugar da aceitação ou da recusa pura e simples, que se havia de esperar. $\mathrm{O}$ oferente passa à situação de destinatário da nova oferta e tem de aceitá-la, ou de recusá-la, ou, por sua vez, em lugar de proceder como destinatário, novamente oferecer. Nesse jôgo de tênis de ofertas, tem-se de chegar ao ponto final: ou uma delas é aceita, totalmente, e pois não há pensar-se em nova oferta; ou há a recusa (nada feito)".
}

Após esta fixação sumária do processo de dinâmica contratual, desse jogo de saque e troca de ofertas, às vezes com acordos parciais sobre determinados pontos, até a conclusão do negócio jurídico bilateral ou plurilateral com eficácia de constituição, modificação, regulação ou extinção de relações jurídicas patrimoniais, em função de uma operação econômica concreta, é possível analisar as diversas classificações dogmáticas dos contratos.

386 “Art. 431. A aceitação fora do prazo, com adições, restrições, ou modificações, importará nova proposta". 


\subsection{As classificações dos contratos}

A crescente complexidade do mundo natural e suas repercussões no mundo jurídico incrementam a problemática associada aos processos de criação de conceitos e definições, exigindo abstração e generalidade cada vez maiores e não raro tornando impossível a delimitação do conceito ou a levam a conceitos por demais amplos, sem verdadeira utilidade no pensamento. Como resposta, o método conceitual impõe o expediente classificatório, por meio do qual são criadas classes ideais nas quais os fenômenos reais serão enquadrados por subsunção, bastando corresponder aos critérios distintivos entre uma classe ou outra. $\mathrm{O}$ critério classificatório passa a ter um papel central, pois o mesmo fenômeno pode ser classificado de maneiras diversas conforme o critério de classificação adotado, o que não é logicamente falso na medida em que os muitos critérios classificatórios procuram analisar facetas diferentes do fenômeno, atomizando cada parte constitutiva e transformando-a em objeto próprio de estudo. Em seguida, as diversas classificações são fundidas num conceito mais concreto do que as categorias gerais, permitindo uma compreensão mais globalizante do fenômeno analisado. Quanto mais critérios classificatórios adotados, maior a probabilidade de o conceito concreto retratar fielmente o fenômeno pela reconstrução das diversas partes constitutivas.

$\mathrm{Na}$ dogmática jurídica, o método classificatório é extremamente importante para a compreensão dos fatos jurídicos e de seus efeitos, assumindo especial tom no campo contratual, tendo em vista ampla criatividade dos sujeitos de situações jurídicas no exercício do poder de autorregramento privado para vestir as mais diversas e novas operações econômicas. Assim, esta seção secundária analisará de maneira sintética as mais importantes classificações de contratos propostas tradicionalmente pela doutrina e que tenham utilidade na tarefa de classificar e, posteriormente, qualificar o contrato de participação em grupo de consórcio ${ }^{387}$.

387 Não há a pretensão de se esgotar os critérios classificatórios dos contratos, pois a grande complexidade do fenômeno contratual em suas mais diversas dimensões torna impossível uma classificação exaustiva dos contratos. Serão analisadas as classificações tradicionais e que possam mais contribuir na classificação e posterior qualificação do contrato de participação em grupo de consórcio. 


\subsubsection{Classificação dos contratos pela sua função econômica}

Devido ao modelo dogmático de contrato adotado, reconhecendo o papel do fato econômico subjacente ao contrato, o primeiro critério classificatório deve olhar para a operação econômica concreta envolvida na vestimenta jurídica contratual, pois é ela quem dá a substancia do contrato, é por causa dessa operação econômica particular que as partes decidem exercitar seu poder de autorregramento, modificando suas esferas jurídicas não apenas com a constituição, a modificação, a regulação ou a extinção de relações jurídicas patrimoniais, mas a fim de obter, após a conclusão e execução do contrato, uma mudança mais profunda em sua esfera jurídica, com a realocação de posições jurídicas subjetivas ativas e passivas das esferas jurídicas dos sujeitos de situações jurídicas.

Com base no critério da função econômica, F. MESSINEO ${ }^{388}$ propôs dividir os contratos em oito classes distintas, podendo comportar subclasses ou espécies, a saber: (1) contratos que disciplinam relações familiares patrimoniais; (2) contratos facilitadores da circulação de riqueza; (3) contratos de colaboração; (4) contratos de prevenção de risco e de previsão; (5) contratos de conservação e de cautela; (6) contratos tendentes a prevenir ou dirimir uma controvérsia; (7) contratos de concessão de créditos; e (8) contratos constitutivos de direitos reais de gozo ou de garantia.

Aparentemente, o objetivo não declarado do autor ao criar uma classe específica para os contratos disciplinadores de relações familiares patrimoniais foi ressaltar que tais contratos, apesar de criarem, de modificarem, de regularem ou de extinguirem relações jurídicas obrigacionais ou reais, estão adstritos aos princípios jurídicos próprios do Direito de Família e devem, por tal razão, receber um tratamento classificatório específico. Do ponto de vista da funcional, porém, é impróprio falar em operações econômicas familiares, na medida em que a criação e a circulação de riqueza características da operação econômica não são substancialmente afetadas pelo fato da operação ocorrer dentro ou fora da família. Para a Economia enquanto campo de estudo, pode até ser interessante analisar tais operações econômicas sob um microscópio especial, mas por mais características próprias atribuídas, as operações econômicas no âmbito familiar ainda são operações econômicas. Para a dogmática jurídica, no entanto, criar uma classe específica dentro de uma classificação cujo critério discriminador é a função econômica subjacente ao contrato,

388 Cf. Doctrina General del Contrato cit., pp. 35-37. 
acaba por baralhar o pensamento classificatório pela sobreposição de critérios. Um critério de classificação pela função econômica, então, exclui a categoria dos contratos disciplinadores de relações jurídicas familiares patrimoniais, deixando a discussão sobre se os princípios do Direito de Família são ou não aplicáveis como critério discriminador das categorias de contratos pelo regime jurídico aplicável.

Na proposta de F. MESSINEO, a categoria dos contratos facilitadores da circulação de riqueza é composta pelos contratos aptos a estimular e formalizar o intercâmbio de bens, que pode ser com sacrifício econômico para ambas as partes (oneroso) ou com sacrifício econômico para apenas uma ou algumas partes contratuais (gratuito) ${ }^{389}$. Os contratos dessa categoria podem ser subdivididos em (1) contratos de intercâmbio que visem formalizar um dou e dê (do ut des) ou um toma-lá-dá-cá, nos quais a matéria de intercâmbio é a transferência da plenitude de poderes econômicos sobre um bem de um lado contra a transferência da plenitude de poderes econômicos sobre outro bem do lado oposto $^{390}$; (2) contratos de intercâmbio que visem um dou-e-faça (do ut facias), por meio dos quais há a troca entre a plenitude de poderes econômicos sobre determinado bem contra uma conduta positiva ou negativa dotada de valor econômico ${ }^{391}$; (3) contratos de intercâmbio formalizando uma operação econômica de faço-e-faça (facio ut facias), por meio dos quais há a troca de uma conduta positiva ou negativa dotada de valor econômico por outra conduta positiva ou negativa também dotada de valor econômico ${ }^{392}$; e (4) contratos de intercâmbio que formalizam uma operação econômica de dou ou faço, por meio dos quais há a transferência da propriedade de um bem ou a realização de uma conduta positiva ou negativa dotada de valor econômico em que a troca é simplesmente o enriquecimento da outra parte ${ }^{393}$. Sob o critério da função econômica, os conceitos de dar e fazer são um tanto diferentes da noção comum, considerando-se o dar a transferência de poderes econômicos plenos sobre um bem e o fazer a transferência de poderes econômicos de gozo (usar e fruir) sobre determinado bem ${ }^{394}$.

A categoria dos contratos de colaboração ou de cooperação, por sua vez, engloba os contratos cuja operação econômica subjacente consiste no desempenho de atividade em colaboração ou com a cooperação entre as partes contratuais, ainda que a atividade de cada 
parte seja independente ou autônoma em relação à atividade da outra parte ou das outras partes $^{395}$. Nesse sentido, os contratos de colaboração conferem uma vestimenta jurídica para as operações econômicas criadores de riqueza, pois atuam nas diversas formas e dimensões do momento econômico da produção de bens ou de serviços ${ }^{396}$.

Autoexplicativas, as demais categorias de contratos classificados pela operação econômica não necessitam de maiores esclarecimentos, englobando operações como o seguro, o depósito, a intermediação de crédito, o usufruto e a hipoteca.

Tendo em vista a íntima relação entre a operação econômica e contrato como vestimenta jurídica dessa operação, é possível perceber uma aproximação muito forte entre a classificação pela função econômica do contrato e a classificação pelo objeto contratual. Entretanto, a classificação pela função econômica divide os contratos pelo sua causa, a compreensão do por que as partes concluíram determinado contrato em concreto, enquanto uma classificação pelo objeto divide os contratos com base na resposta obtida ao questionamento "o quê", qual é o objeto do contrato.

\subsubsection{Contratos reais e contratos consensuais}

A categoria dos contratos reais e dos contratos solenes relaciona-se com os elementos de existência, com a verificação ou não de elementos nucleares do suporte fático das normas jurídicas tipificadoras de determinados contratos. No modelo dogmático contratual, por princípio conclui-se o contrato pelo encontro e pela soldagem da eficácia do negócio jurídico unilateral de oferta com a eficácia do sucessivo negócio jurídico unilateral de aceitação, bastando assim a existência de acordo, do encaixe de eficácia de oferta e de aceitação sobre os elementos nucleares do suporte fático do contrato para a norma jurídica. Como regra, então, os contratos são meramente consensuais, concluindo-se e entrando no mundo jurídico pelo mero consenso sobre os elementos de existência desse contrato, como, por exemplo, o contrato de compra-e-venda que existirá no mundo como tal sempre que as partes, vendedor e comprador, consentirem com a transferência da propriedade e da posse de determinada coisa pelo vendedor contra a transferência da propriedade e da posse de moeda corrente nacional em quantidade suficiente para compor certa soma de valor. 
Apesar da regra geral da formação contratual fixar a fusão eficacial do negócio jurídico unilateral de oferta com o negócio jurídico unilateral de aceitação como núcleo do suporte fático, há situações nas quais o ordenamento jurídico, no âmbito do seu processo de valoração, inclui alguns elementos completantes do núcleo do suporte fático de certos tipos contratuais, de maneira que a incidência da norma jurídica depende da suficiência desses elementos completantes. Assim, denomina-se contrato real a classe de contratos que possuem o acordo de transmissão da posse, o acordo de transmissão da propriedade, o atofato jurídico real de entrega ou o ato-fato jurídico de tradição como elementos completantes do núcleo do suporte fático desses contratos, cujo cerne é composto pela soldagem das eficácias do negócio jurídico de oferta e do negócio jurídico de aceitação. Na tradição pátria, o comodato é o exemplo clássico de contrato real ${ }^{397}$ cujos elementos de existência consistem na oferta de contrato de transferência gratuita da posse de coisa infungível para uso e posterior restituição, na aceitação dessa oferta, na celebração do acordo de transmissão da posse e na efetiva entrega da coisa (art. 579 do Código Civil ${ }^{398}$ ). Em linha semelhante, também o mútuo é tratado como contrato real ${ }^{399}$, considerando-se o acordo de transmissão da posse, o acordo de transmissão da propriedade e a tradição como elementos completantes do núcleo do suporte fático do mútuo, elementos esses que completam o encontro da oferta com a aceitação que se compõe o cerne do núcleo do suporte fático do contrato de mútuo.

Como as normas jurídicas disciplinadoras dos contratos reais somente incidem quando verificado o suporte fático suficiente, e como o suporte fático dos contratos reais prevê o acordo de transmissão da posse, o ato-fato jurídico de entrega, eventualmente o acordo de transmissão da propriedade e o ato-fato jurídico real da tradição, inexistindo a entrega ou a tradição (e os respectivos acordos de transmissão da posse e da propriedade), o suporte fático é insuficiente e não sofre a incidência das ditas normas jurídicas. Ou seja, sem o acordo de transmissão da posse e a entrega ou sem o acordo de transmissão da propriedade e a tradição, os contratos reais não existem como tais. $\mathrm{O}$ fenômeno se passa

397 Cf. C. Bevilaqua, Código Civil dos Estados Unidos do Brasil, vol. IV, 11. a ed. atual. por Achilles Bevilaqua e Isaías Bevilaqua, Rio de Janeiro, Francisco Alves, 1958, p. 352; S. DE SALvo VenosA, Direito Civil, vol. III - Contratos, 10. ${ }^{a}$ ed., São Paulo, Saraiva, 2010, p. 180.

398 "Art. 579. O comodato é o empréstimo gratuito de coisas não fungíveis. Perfaz-se com a tradição do objeto.”.

$399 \quad$ Cf. C. Bevilaqua, Código Civil dos Estados Unidos do Brasil cit., vol. IV, p. 357; S. DE SALvo Venosa, Direito Civil cit., vol. III, p. 194. A classificação de contrato real conferida ao mútuo decorre de reminiscências históricas, pois inexiste dentre as normas jurídicas enunciadas no Código Civil proposição jurídica semelhante ao comodato com relação ao aperfeiçoamento do contrato pela tradição da coisa. 
completamente no plano da existência ${ }^{400}$. Em tais situações de ausência da entrega ou da tradição, até pelo princípio da conservação dos negócios jurídicos, é comum sustentar a possibilidade das partes concluírem um contrato preliminar por meio do qual uma das partes fica adstrita a celebrar o contrato real definitivo por meio da celebração do acordo de transmissão da posse, da realização do ato-fato jurídico real de entrega, da celebração do acordo de transmissão e a prática do ato-fato jurídico de tradição completantes do núcleo do suporte fático do contrato ${ }^{401}$.

Conceitualmente, a inclusão do elemento real (ato-fato jurídico real de entrega ou de tradição) como elemento de existência de alguns contratos leva em conta o caráter de honra e cortesia subjacentes a tais operações econômicas, permitindo que a parte realizadora da atribuição patrimonial mude de ideia e desista de realizar a operação se a conduta ou situação da contraparte puder gerar insegurança e quebra da relação de confiança inerente a esse tipo de negócio. Analisando os contratos de comodato, de mútuo e de depósito no ordenamento jurídico português, C. A. Mota PINTO faz críticas contundentes à categoria dos contratos reais, afirmando que "falece [...] uma razão teleológica, legitimadora de sua qualificação real", pois a categoria não corresponde nos dias atuais "a uma função útil ou a um interesse suficientemente relevante" ${ }^{402}$. Raciocina que eventual lógica de proteção de um dos lados contratuais adotada pelo ordenamento jurídico por fazer depender a existência mesma do contrato à atribuição patrimonial realizada por essa parte, essa lógica de proteção não pode afastar o princípio do Direito Privado da livre disponibilidade das posições jurídicas subjetivas ativas patrimoniais, permitindo à parte renunciar a essa proteção sem modificar a categoria de contratual ${ }^{403}$. Também não faz sentido o argumento da necessária entrega prévia para justificar o dever e a obrigação de restituir típicos das figuras contratuais reais, pois, além de existirem contratos consensuais com prestação de restituição, como a prestação do locatório após o término da locação ${ }^{404}$, o argumento confunde os deveres e obrigações, que são fenômenos do plano da eficácia, com questões relacionadas com a existência do contrato. Assim, a manutenção da categoria dos contratos reais é um anacronismo histórico do início da evolução do Direito Romano, tendo em vista que, como aponta R. ZIMMERMANN, no

\footnotetext{
$400 \quad$ Sem razão I. GALVÃo Telles (Manual dos Contratos em Geral cit., p. 467), que por baralhamento dos planos do mundo jurídico, enxerga no contrato real sem a transferência da posse um contrato inválido, eventual passível de conversão substancial em contrato preliminar.

401 Cf. M. Bernardes De Mello, Teoria do Fato Jurídico - Plano da Existência cit., p. 250.

402 Cessão da Posição Contratual, Coimbra, Almedina, 2003, p. 11, nota 1.

403 Cf. C. A. Mota Pinto Cessão da Posição Contratual, Coimbra, Almedina, 2003, pp. 11-12, nota 1

404 Cf. C. A. Mota PINTO, Cessão da Posição Contratual, Coimbra, Almedina, 2003, pp. 12-13, nota.
} 
período clássico a força vinculante do mútuo decorria do consenso entre as partes, ficando o elemento real, o dare re, como o pressuposto lógico para a utilização da conditio para a restituição da coisa $^{405}$. Acrescente-se que o espírito prático dos romanos estava mais preocupado com o momento do surgimento da relação obrigacional contendo o dever de restituição do que com o momento de conclusão do contrato. Ora, um modelo dogmático capaz de lidar corretamente com o plano da existência e com o plano da eficácia não precisa da categoria dos contratos reais.

Apesar da discussão a respeito da utilidade ou inutilidade da categoria dos contratos reais nos ordenamentos jurídicos contemporâneos, não se pode esquecer que as normas jurídicas pátrias efetivamente tratam o elemento real como elementos completantes do seu suporte fático, tornando a incidência dependente da verificação de tais elementos, tornando necessário conservar a distinção entre contratos reais e contratos consensuais. Por outro lado, o poder de autorregramento dos sujeitos concretizado na liberdade de contratar alinhado com o modelo contratual pautado na dinâmica da oferta e da aceitação, permite concluir que é totalmente possível existirem contratos de mútuo e contratos de comodato sem os acordos de transmissão e a entrega ou tradição, contratos esses eventualmente não legalmente típicos, mas socialmente tipificados e aceitos ${ }^{406}$. Nesse sentido, F. C. PONTES DE MIRANDA esclarece que a criatividade dos sujeitos no exercício de seu poder de autorregramento permite conceber e aceitar contratos consensuais correspondentes aos contratos reais:

\footnotetext{
"Em verdade, o fato de a lei ter concebido o negócio jurídico como negócio jurídico real apenas significa que os princípios expostos a respeito do negócio jurídico típico somente se hão de invocar se o negócio jurídico real se perfaz. De modo nenhum se há de concluir que se vedam pré-contratos, ou que se afasta a perfeicão de negócios jurídicos consensuais que lhes correspondam. A atitude que sustenta o contrário revela resíduo histórico e sistemático, já hoje injustificável [...]. O direito de hoje parte do pressuposto da vinculabilidade livre. Não mais há a distinção romana entre contratos que são ou podem ser consensuais e contratos que sômente podem ser reais. Hoje, os contratos ou são consensuais ou são reais, porém o que se tinha como contrato imprescindivelmente real deixou de existir. Há contratos consensuais que correspondem aos contratos reais. O que se passa é que não exsurge o dever que, por sua natureza, depende de ter havido o fato real; e. $g$., o dever de devolver a coisa recebida em comodato ou de restituir o que se deva em mútuo. Aliás, ocorre o mesmo com a locação de bens: o arrendatário somente tem o dever de devolver o bem tocado se o recebeu. E o arrendamento não é contrato real" 407 .
}

\footnotetext{
$405 \quad$ Cf. The Law of Obligations cit., pp. 155 e ss.

406 Cf. C. A. Mota Pinto, Cessão da Posição Contratual, Coimbra, Almedina, 2003, pp. 14, nota.

407 Cf. F. C. PONTES DE MIRANDA, Tratado de Direito de Privado cit., t. XXXVIII, $\S 4.254$, n. 3, p. 361, reforços gráficos não originais.
} 


\subsubsection{Contratos solenes e não solenes}

Esta categoria utiliza como critério a presença ou não de certa forma especial ou necessidade observância de determinado procedimento rígido para a conclusão do contrato como requisitos de validade e, excepcionalmente, como elementos de existência do contrato $^{408}$. Diz respeito ao plano da validade e, excepcionalmente, ao plano da existência, e não engloba as situações nas quais apesar de determinado tipo contratual não requerer forma específica para a sua validade, tal forma ou solenidade é necessária para a prova do contrato e da relação jurídica contratual. Estão incluídos na categoria de contratos solenes todos os contratos que possuam como elemento de existência ou requisito de validade determinada forma prescrita em norma jurídica ou observância de certa solenidade, procedimento disciplinado pelo ordenamento jurídico e considerado fundamental para a plena validade do contrato. Por contraposição, são considerados contratos não solenes todos os tipos contratuais nos quais a existência e a validade não dependem de certa forma imposta por normas jurídicas nem da observância de procedimentos para a conclusão ou documentação do contrato.

Não se pode incorrer no equívoco de considerar os contratos não solenes como contratos sem forma, pois a forma faz parte do funcionamento do universo, na medida em que todo acontecimento, todo evento ou conduta ocorre desenvolve-se em alguma forma. Consequentemente, todo fato jurídico, incluindo os negócios jurídicos e os contratos, possuem algum tipo de forma como elemento de existência, devendo-se a expressão "aformal" ou "sem formal" serem entendidas como elipses da expressão "sem forma prescrita", conforme pontua F. C. PONTES DE MIRANDA:

\footnotetext{
"Não há negócio jurídico, unilateral, bilateral, ou plurilateral, sem forma, defeito que a expressão 'aformal' tem de ser entendida como 'sem forma especial'. A manifestação de vontade oral, ou por gestos, tem forma, mas diz-se aformal, no sentido estrito a que nos referimos ${ }^{, 409}$.
}

Por princípio, há ampla liberdade formal para os negócios jurídicos e contratos em 
função da consagração do poder de autorregramento dos sujeitos ${ }^{410}$, de modo a serem admitidos no plano da existência negócios jurídicos e contratos pela simples exteriorização da decisão negocial. Exteriorizar a decisão negocial relaciona-se a por em marcha, executar um plano de ação desenvolvido na mente e cujos atos implicam uma comunicação em linguagem compreensível pelos demais sujeitos figurantes do negócio jurídico ou do contrato. De ordinário, basta essa conduta compreensível como decisão do sujeito, como o querer dos voluntaristas, para o elemento de existência forma estar preenchido. Entretanto, existem situações nas quais a norma jurídica exige uma forma especial, e essa exigência formal pode, conforme a valoração do ordenamento jurídico, ser tratada como elemento de existência ou como requisito de validade do negócio ou do contrato. $\mathrm{O}$ casamento e o testamento, respectivamente um negócio jurídico bilateral não contratual de Direito de Família e um negócio jurídico unilateral de Direito das Sucessões, são exemplos de negócios jurídicos para os quais a exigência de forma especial ganha contornos especialíssimos, atuando no próprio plano da existência ${ }^{411}$. Como regra, porém, quando o ordenamento exige certa forma para a prática do ato jurídico ou do negócio jurídico, tal exigência atua no plano da validade (art. 104, inciso III do Código Civil ${ }^{412}$ ), tornando nulo o ato, o negócio ou o contrato (art. 166 do Código Civil ${ }^{413}$ ).

\subsubsection{Contratos onerosos e gratuitos}

De ordinário, a classificação entre contratos onerosos e gratuitos utiliza como critério diferenciador a análise do objeto do contrato, isto é, o objeto da relação jurídica contratual, resultando na classificação de onerosos os contratos nos quais há prestação e contraprestação e como gratuitos os contratos cujo objeto consiste apenas em uma

\footnotetext{
$410 \quad$ Cf. F. Galgano, Il Negozio Giuridico cit., p. 134.

411 "Art. 166. É nulo o negócio jurídico quando:

I - celebrado por pessoa absolutamente incapaz;

II - for ilícito, impossível ou indeterminável o seu objeto;

III - o motivo determinante, comum a ambas as partes, for ilícito;

IV - não revestir a forma prescrita em lei;

$\mathrm{V}$ - for preterida alguma solenidade que a lei considere essencial para a sua validade;

VI - tiver por objetivo fraudar lei imperativa;

VII - a lei taxativamente o declarar nulo, ou proibir-lhe a prática, sem cominar sanção".

412 “Art. 104. A validade do negócio jurídico requer:

III - forma prescrita ou não defesa em lei”. 
prestação de um lado a outro ${ }^{414}$. V. RoPPo traz alguns traços distintivos importantes, ressaltando que não basta haver prestação e contraprestação para caracterizar um contrato oneroso, sendo preciso também que a prestação seja um sacrifício jurídico-econômico realizado por uma parte em troca da vantagem jurídico-econômica representada pela contraprestação da outra parte. Ademais, a relação entre vantagem e sacrifício jurídicoeconômico pressupõe a satisfação de um interesse anterior e externo ao contrato por meio da prestação contratual, e nunca um interesse sucessivo ou decorrente do contrato ${ }^{415}$.

A noção de vantagem e sacrifício jurídico-econômico pode ser expressa tecnicamente pelo conceito jurídico de atribuição patrimonial ${ }^{416}$, distinto dos conceitos próximos de disposição e alienação, uma vez que toda alienação é uma disposição e uma atribuição patrimonial, mas nem toda disposição é alienação e nem toda disposição é uma atribuição patrimonial. Haverá atribuição patrimonial sempre que um sujeito proporciona a outro um benefício patrimonial, que pode consistir tanto num efetivo incremento patrimonial como no impedimento de diminuição do patrimônio de outrem. Pode haver atribuição patrimonial, por exemplo, quando (1) há disposição de uma posição jurídica subjetiva; (2) há um benefício patrimonial de A sem a diminuição correspondente do patrimônio de B; (3) ocorrem atos-fatos jurídicos que impliquem benefício patrimonial para outrem, como a prescrição e a decadência; e (4) há assunção de dever patrimonial por um sujeito frente a outro ${ }^{417}$. Verifica-se a disposição, por sua vez, quando um sujeito pratica um negócio jurídico que tem como eficácia imediata a modificação de uma relação jurídica ou uma posição jurídica subjetiva ativa de maneira a diminuir o ativo patrimonial de sua titularidade ${ }^{418}$, modificando de tal maneira a relação jurídica que os atos jurídicos lato sensu ulteriores encontram limites no ato dispositivo anterior. Nesse sentido, são espécies de disposição: (1) alienação; (2) gravame real; (3) alteração da posição jurídica subjetiva; e (4) renúncia ${ }^{419}$. Importante notar que só haverá disposição quando a modificação na posição jurídica subjetiva ativa implique a perda ou enfraquecimento desta posição jurídica subjetiva ativa. Destarte, a assunção de deveres não é disposição, mas

414 Cf. F. C. Pontes De MIRANDA, Tratado de Direito de Privado cit., t. XXXVIII, § 4.258, n. 1, pp. 359-360.

415 Il Contratto, Milano, Giuffrè, 2001, pp. 434-435.

416 Cf. J. M. ANTunes VARela, Das Obrigações em Geral, vol. I, 10. a ed. rev. e atual., Coimbra, Almedina, 2002, p. 404; I. GALVÃo Telles, Manual dos Contratos em Geral cit., p. 480.

$417 \quad$ Cf. A. vON TuHr, Derecho Civil - Teoría General del Derecho Civil Alemán, trad. espa. Tito Ravá, vol. III, Madrid, Marcial Pons, 2005, p. 45 ss.

418 Cf. A. von TuHR, Tratado de las Obligaciones, trad. esp. W. Roces, Granada: Comares, 2005, p. 115.

419 Cf. A. von TuHr, Derecho Civil - Teoría General del Derecho Civil Alemán, trad. esp. Tito Ravá, vol. II, Madrid, Marcial Pons, 2005, pp. 215 e ss. 
constituição. Por fim, haverá alienação quando decorrer de negócio jurídico dispositivo a sucessão translativa da integralidade de uma posição jurídica subjetiva de uma esfera jurídica a outra, de maneira que o titular anterior sofra uma perda definitiva desta posição jurídica subjetiva $^{420}$.

Focalizar a distinção entre onerosidade e gratuidade na atribuição patrimonial, além de aproximar a análise do elemento econômico, da operação subjacente ao contrato, evita confundir a classificação com os contratos unilaterais, bilaterais e plurilaterais, pois em tese é possível compreender um contrato unilateral e oneroso ${ }^{421}$. Desse modo, os contratos onerosos caracterizam-se pela necessidade imposta a todas as partes de realização de atribuição patrimonial (= sacrifício) em favor de outra parte para beneficiar-se de uma atribuição patrimonial. Nos contratos gratuitos falta a reciprocidade da atribuição patrimonial, pois uma ou algumas partes atribuem em favor de outras partes, mas nem todas as partes beneficiadas pela atribuição realizam uma contra atribuição patrimonial ${ }^{422}$.

A compreensão do papel da atribuição patrimonial também permite discernir a diferença entre gratuidade e liberalidade. Relaciona-se a gratuidade com a realização de atribuição patrimonial em favor de outrem sem que esse precise suportar o sacrifício de fazer outra atribuição patrimonial em reciprocidade. Mas como visto, o conceito de atribuição patrimonial é deveras amplo e engloba situações nas quais há incremento patrimonial ou evita-se a redução patrimonial sem necessariamente ocorrer empobrecimento do sujeito que realiza a atribuição patrimonial. Sempre que a atribuição patrimonial envolver o empobrecimento de um sujeito (redução do ativo ou aumento do passivo) e o enriquecimento de outro (aumento do ativo ou redução do passivo) sem a reciprocidade da atribuição patrimonial, haverá liberalidade. Por outro lado, nas hipóteses nas quais há atribuição patrimonial que não consista em enriquecimento de um sujeito (aumento do ativo ou redução do passivo) ou empobrecimento (redução do ativo ou aumento do passivo) de outro, como no comodato, no mútuo e no mandato, haverá gratuidade, mas sem liberalidade ${ }^{423}$.

\footnotetext{
$420 \quad$ Cf. A. vON TUHR, Derecho Civil cit., pp. 53 e ss. Para uma síntese e confronto dos conceitos, conferir M. Domingos DE ANDRADE, Teoria geral da relação jurídica, vol. II, Coimbra, Almedina, 2003, pp. 66-68.

421 Cf. J. M. Antunes Varela, Das Obrigações em Geral cit., vol. I, p. 405.

422 Cf. I. Galvão Telles, Manual dos Contratos em Geral cit., p. 480; J. M. Antunes Varela, Das

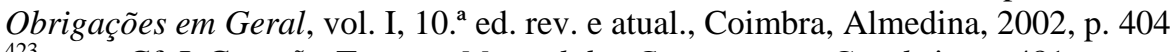

423 Cf. I. Galvẽo Telles, Manual dos Contratos em Geral cit., p. 481.
} 


\subsubsection{Contratos comutativos e aleatórios}

Como o modelo dogmático reconhece os contratos como as vestes jurídicas de operações econômicas, o risco, uma das noções mais fortes do agir econômico, também está presente na lógica contratual, pois as diversas cláusulas de um contrato voltadas a proteger esse ou aquele interesse, do ponto de vista econômico, estão orientadas a fazer um esforço de alocação do risco econômico, da possibilidade de perda e da possibilidade de ganho. Existem contratos, porém, nos quais a álea ganha especial relevo, gerando não apenas um risco econômico para uma das partes, mas também um risco jurídico. A noção de álea possui um perfil objetivo relacionado com a sorte e um perfil subjetivo relacionado com risco, inserindo-se nos contratos onerosos nos quais uma das partes assume o risco de determinado fato (evento ou conduta) criar-lhe a obrigação de prestar sem a contraprestação da outra parte ou com contraprestação economicamente desproporcional em relação à vantagem e à desvantagem das prestações ${ }^{424}$.

Em termos simples, pertencem à categoria dos contratos aleatórios todas as figuras contratuais nas quais as partes assumem um risco com relação à prestação em si e por si (e não apenas com relação ou custo ou ao valor), causador de desequilíbrio econômico por fazer que a vantagem econômica (e não apenas patrimonial) de uma parte seja obtida apenas com perda econômica (e não apenas patrimonial) da outra parte ${ }^{425}$.

Nos contratos aleatórios, a causa da prestação de uma das partes não é a contraprestação da outra, mas a obtenção da possibilidade de auferir ganhos econômicos decorrentes de fato ou fatos incertos cuja não verificação conforme esperado resultará num prejuízo econômico pelo menos correspondente à prestação realizada. Assim, nos contratos de compra de coisa futura na qual o comprador assume o risco da coisa não vir a existir, a causa da prestação do comprador é exatamente a assunção do risco, ele paga o preço não pela coisa, mas por colocar-se em posição de beneficiar-se com a possibilidade da coisa vir a existir. Essa possibilidade da coisa vir a existir possui valor econômico, e é essa possibilidade que o comprador de coisa futura está, na verdade, comprando. $\mathrm{O}$ vendedor, por outro lado, sofre uma perda econômica com relação ao custo de oportunidade, na medida em que a coisa futura já está vendida a determinado sujeito. Há reciprocidade nas atribuições econômicas das expectativas e riscos, mas pode não haver reciprocidade nas

$424 \quad$ Cf. V. Roppo, Il Contratto cit., p. 443.

425 Cf. V. RopPo, Il Contratto cit., pp. 443-444. 
prestações, e essa possibilidade, esse risco, caracteriza o contrato aleatório, sem desnaturar a onerosidade ${ }^{426}$. Logicamente, a categoria contraposta dos contratos comutativos engloba os contratos onerosos nos quais a prestação não corre risco jurídico (risco da prestação em si e por si) nem risco econômico relacionado ao seu valor ou utilidade ${ }^{427}$.

4.6.6. Contratos de prestações correspectivas, contratos de prestação de uma parte, contratos de prestações para consecução de escopo comum

É comum classificar como unilateral o contrato por meio do qual apenas uma das partes figura no polo passivo da relação jurídica obrigacional, ficando adstrita a cumprir o dever jurídico principal de prestação, e como contrato bilateral ou sinalagmático aquele contrato por meio do qual a ambas as partes são imputadas posições jurídicas subjetivas passivas complexas cujo objeto é a realização da prestação ${ }^{428}$. No mesmo sentido, emprega-se o termo contrato plurilateral para classificar os contratos nos quais há pluralidade de partes e cada uma das partes figura no polo passivo da relação jurídica contratual com a titularidade de posição jurídica subjetiva passiva complexa com objeto correspondente à prestação principal. Denominar as categorias contratuais de unilaterais e bilaterais pode gerar confusões com os negócios jurídicos unilaterais, bilaterais e plurilaterais, pois a lateralidade em cada caso diz respeito a situações diferentes ${ }^{429}$. A lateralidade do negócio jurídico atua no plano da existência, relacionando-se com o número de lados ou centros autônomos de interesses originários das decisões negociais. Cada centro de interesse pode ter muitos figurantes concentrados em torno de um ou vários interesses e a exteriorização da decisão desse centro de interesses, desse lado do negócio jurídico, faz-se por meio dos atos coletivos (e atos colegiais), nas quais as várias manifestações ou declarações lado a lado e no mesmo sentido para formar uma única decisão ${ }^{430}$. O negócio jurídico será unilateral se tiver apenas um lado, um único centro de

\footnotetext{
426 Cf. I. Galvão Telles, Manual dos Contratos em Geral cit., p. 483.

$427 \quad$ Cf. V. RopPO, Il Contratto cit., p. 445.

428 Cf. S. Salvo Venosa, Direito Civil cit., vol. III, pp. 403-404; J. M. Antunes Varela, Das Obrigações em Geral cit., vol. I, pp. 395-396.

429 Cf. F. MessineO, Doctrina General del Contrato cit., p. 414.

$430 \quad \mathrm{O}$ ato coletivo pode ser dividido em ato coletivo criativo (como na fundação) e ato coletivo autorizativo, que pode ser aprovativo ou ratificativo. Entretanto, o ato coletivo não é espécie autônoma dentro da classificação dos fatos jurídicos, mas apenas um modo de formação de um ato jurídico stricto sensu ou de um negócio jurídico para os quais não se pode considerar as decisões convergentes como distintas, mas
} 
interesses, ainda que multifigurativo e complexo, do qual se origina a decisão negocial. Por sua vez, o negócio jurídico será bilateral ou plurilateral se possuir dois ou mais lados, centros autônomos de interesses simples ou complexos, unifigurativos ou multifigurativos, dos quais emanam negócios jurídicos unilaterais contrapostos e convergentes e que são fusionados em um único negócio jurídico bilateral ou plurilateral. Conforme o modelo dogmático, o contrato é fruto da soldagem da eficácia do negócio jurídico unilateral de oferta e do negócio jurídico unilateral de aceitação, de maneira que todo contrato é, no plano da existência, um negócio jurídico bilateral ou plurilateral ${ }^{431}$. A unilateralidade, bilateralidade ou pluralidade nos contratos diz respeito ao plano da eficácia, aos efeitos jurídicos contratuais, mas especificamente ao objeto da relação jurídica ${ }^{432}$. Desse modo, para evitar as confusões no pensamento e ressaltar que o critério diferenciador da categoria é reciprocidade das prestações, adota-se a terminologia proposta pelos autores italianos entre a categoria dos contratos de prestação correspectiva, dos contratos de prestação de apenas uma parte e dos contratos de prestações para fim comum ${ }^{433}$.

A categoria do contrato de prestações correspectivas (ou recíprocas) engloba os contratos por meio do qual todas as partes são titulares de posições jurídicas subjetivas passivas complexas denominadas dívida ou débito cujos objetos consistem em prestações principais ou típicas ligadas entre si por um nexo de mútua reciprocidade e interdependência denominado tradicionalmente sinalagma ${ }^{434}$. Para que exista a correspectividade ou o sinalagma é preciso que as prestações sejam recíprocas, ou seja, a realização de uma prestação pressupõe a realização da outra, e interdependentes, no sentido de que uma prestação é baseada ou encontra sua causa na outra ${ }^{435}$. A noção de reciprocidade também pressupõe que as posições jurídicas subjetivas passivas complexas de dívida nasçam ao mesmo tempo, ainda que o nascimento das posições jurídicas subjetivas elementares de obrigação seja escalonado por prazos diferentes de vencimento das dívidas ${ }^{436}$. Referida relação lógica de reciprocidade e interdependência entre as prestações necessariamente encontra sua gênese no momento de celebração do contrato,

apenas integrativas de uma única decisão (Cf. F. C. PONTES DE MIRANDA, Tratado de Direito Privado cit., t. III, §283, p. 171).

Cf. J. M. Antunes VAREla, Das Obrigações em Geral cit., vol. I, pp. 396.

432 Cf. F. MEssineo, Doctrina General del Contrato cit., p. 410.

433 Cf. F. Messineo, Doctrina General del Contrato cit., p. 410, V. RopPo, Il Contratto cit., p. 439.

434 Cf. F. Messineo, Doctrina General del Contrato cit., p. 411, V. RoPPO, Il Contratto cit., p. 439; J. M. Antunes Varela, Das Obrigações em Geral cit., vol. I, pp. 395-397; I. Galvão Telles, Manual dos Contratos em Geral cit., p. 485.

$435 \quad$ Cf. V. Roppo, Il Contratto cit., p. 439.

436 Cf. F. MESsineo, Doctrina General del Contrato cit., p. 411. 
pois a função econômica-social concreta dos contratos de prestações correspectivas é a circulação, intercâmbio de riqueza por meio da conduta que pode ser exigida do devedor pelo credor para satisfazer um interesse do credor (= prestação) ${ }^{437}$, sendo ordinariamente denominada de sinalagma genético, porque na raiz do contrato as prestação típica ou principal assumida por uma das partes encontra sua causa na prestação típica ou principal assumida pela contraparte ${ }^{438}$. Ademais, a força do nexo de reciprocidade $\mathrm{e}$ interdependência entre as prestações é tão grande que esse nexo deve ser mantido durante toda a vida da relação jurídica contratual, inclusive em face das vicissitudes pelas quais passa a relação, de maneira a assegurar a união e o paralelismo das prestações e a operação econômica para a qual o contrato está funcionalizado. Por isso, a relação de reciprocidade e interdependência durante a vida da relação jurídica contratual recebe o nome de sinalagma funcional $^{439}$, com profundas repercussões no processo contratual, como a exceção de prestação contratual não cumprida ou o poder formativo resolutivo ou resilitvo da relação contratual por força do inadimplemento da prestação no tempo e na forma prevista.

Logicamente, a categoria dos contratos de prestações correspectivas conversa com a categoria dos contratos onerosos, pois todos os contratos de prestações correspectivas pressupõem atribuições patrimoniais de cada uma das partes e favor da outra, no entanto, nem todo contrato oneroso é um contrato de prestações correspectivas. Basta pensar no típico contrato real de mútuo feneratício, caracterizado como oneroso pela atribuição patrimonial inicial por parte do mutuante, e consistindo em elemento de existência do contrato, e a dupla atribuição patrimonial do mutuário relacionada com a restituição da mesma quantidade e qualidade da coisa fungível e transferência de moeda corrente em soma corresponde ao valor dos juros. Nesse exemplo, apesar de evidente a onerosidade, carece o elemento contraprestação recíproca e interdependente, uma vez que a transferência da propriedade da coisa fungível pelo mutuante não foi realizada em cumprimento a nenhuma obrigação, mas apenas concluir o contrato típico de mútuo ${ }^{440}$.

Em outro turno, estão inseridos na categoria dos contratos de prestação de uma

\footnotetext{
437 Cf. V. RopPo, Il Contratto cit., p. 439-440.

438 Cf. J. M. ANTUNES VARELA, Das Obrigações em Geral cit., vol. I, pp. 395-397; I. GALVÃO TELLES, Manual dos Contratos em Geral cit., p. 485.

$439 \quad$ Cf. J. M. Antunes VARELA, Das Obrigações em Geral cit., vol. I, p. 397; I. GALVÃo TELLES, Manual dos Contratos em Geral cit., p. 485.

440 Por outro lado, admitindo-se a celebração de contrato consensual de mútuo feneratício correspondente ao contrato real típico, a imposição de dever e posterior obrigação de transferência da propriedade da coisa fungível pela tradição permite classificar tal contrato atípico como de prestações correspectivas.
} 
única parte aqueles contratos cujo conteúdo eficacial consiste na atribuição à apenas uma parte contratual de posição jurídica subjetiva passiva complexa de dívida da prestação principal ou típica ${ }^{441}$.

O critério discriminador entre as categorias olha para a prestação principal ou típica do contrato e não para as prestações secundárias, acessórias ou laterais ${ }^{442}$, o que permite rejeitar a categoria intermediária dos contratos sinalagmáticos imperfeitos, criada para englobar nas quais o contrato é originariamente um contrato de prestação de única parte, mas dada a dinâmica contratual podem surgir eventuais débitos para a contraparte, como no contrato sem remuneração no qual o mandante deve reembolsar as despesas do mandatário no cumprimento do mandato. Ora, a prestação devida pelo mandante neste caso não é principal ou típica do contrato de mandato, mas apenas eventual, sem qualquer nexo de reciprocidade e interdependência com as prestações do mandatório. Ademais, além da questão das prestações típicas ou principais, também é preciso atentar para o momento de surgimento da dívida de cada parte, porque nos contratos de prestações correspectivas, as dívidas nascem simultaneamente, mesmo que as obrigações nasçam em pontos diferentes do tempo ${ }^{443}$. Mas na pseudo-categoria dos contratos sinalagmaticos imperfeitos, há diferença temporal no nascimento das dívidas, nascendo-se normalmente a dívida principal em primeiro lugar e apenas depois a dívida eventual, há sucessividade e não simultaneidade. Por tais motivos, é forçoso concluir que os chamados contratos de sinalagma imperfeito não passam de contratos de prestação imposta à apenas uma parte ${ }^{444}$.

Contratos de prestações para consecução de escopo comum foram autonomizados em anos recentes, embora a utilidade da categoria ainda seja questionada ${ }^{445}$, como uma categoria de contratos nos quais há multiplicidade de prestações convergentes, mas sem contraprestação ou qualquer correspectividade, pois as partes prestam para atingir ou realizar o fim comum ${ }^{446}$. A função econômica de tais contratos não é o intercâmbio de bens econômicos entre as partes, mas o atingimento de fim comum às diversas partes, donde não

441 Cf. F. Messineo, Doctrina General del Contrato cit., p. 413, V. RopPo, Il Contratto cit., p. 440; J. M. Antunes VAREla, Das Obrigações em Geral cit., vol. I, p. 396; I. Galvão Telles, Manual dos Contratos em Geral cit., p. 486.

442 Cf. C. A. Mota PINTO, Cessão da Posição Contratual cit., pp. 335-380.

443 Cf. F. MESsineO, Doctrina General del Contrato cit., p. 411.

444 Cf. I. Galvão Telles, Manual dos Contratos em Geral cit., p. 486; J. M. Antunes Varela, Das Obrigações em Geral cit., vol. I, p. 398; F. MESSINEO, Doctrina General del Contrato cit., p. 415-416.

445 Cf. A. JunQueIRA DE AZEVEDo, (Parecer) Natureza Jurídica do Contrato de Consórcio cit., p. 353; F. Galgano, Il Negozio Giuridico cit., pp. 202 e ss.

$446 \quad$ Cf. V. RopPO, Il Contratto cit., p. 440. 
se cabe falar em sinalagma. "O fim comum pré-elimina o antagonismo",447, pois impede que uma parte fique à frente da outra parte, mas todas as partes orbitam o fim comum. Ainda assim, os contratos de prestações para consecução de fim comum contém uma reciprocidade indireta e mediata, visto que cada uma das partes presta por causa relação entre as prestações das demais partes e a consecução do escopo comum ${ }^{448}$. O fato de uma das partes não cumprir a sua prestação no âmbito de uma relação jurídica decorrente de contrato de comunhão de escopo não autoriza a resolução dessa relação jurídica, exceto se isso colocar em risco ou inviabilizar o atingimento do escopo comum ${ }^{449}$. Os elementos nucleares da categoria dos contratos de prestações consistem na identidade das prestações $^{450}$ e no escopo comum, tendo em vista que as prestações convergem, fundem-se para o atingimento do escopo comum ${ }^{451}$.

Todo contrato de prestações direcionadas para o atingimento de escopo comum, ainda que composto por apenas duas partes contratuais, é um negócio jurídico plurilateral, pois a comunhão de fim permite a multilateralidade do negócio no plano da existência e multiplicação das partes contratuais no plano da eficácia ${ }^{452}$. O negócio jurídico não perde a plurilateralidade pelo fato de existirem apenas duas partes, porque o elemento nuclear do negócio plurilateral é a finalidade comum e a existência dessa finalidade impõe, logicamente, a adesão de infinitas partes que também compartilhem o mesmo escopo ${ }^{453}$. A natureza de plurilateral do negócio jurídico, então, decorre do fim comum e da possibilidade de participação de mais de duas partes ${ }^{454}$. Por princípio, eventuais defeitos na adesão de uma das partes ao negócio jurídico plurilateral e, desde que o escopo comum ainda seja atingível, não extinguem a relação jurídica decorrente do negócio ${ }^{455}$.

$\mathrm{Na}$ análise das vicissitudes da relação jurídica contratual decorrente do contrato de prestações dirigidas à consecução de escopo comum, é importante reconhecer os diversos

447 F. C. POnTES De Miranda, Tratado de Direito de Privado, t. XLIX, 2. a ed., Rio de Janeiro, Borsoi, $1972, \S 5.169$, n. 2.

448 Cf. T. AsCARElli, O Contrato Plurilateral, in Problemas das Sociedades Anônimas e Direito Comparado, Campinas, Bookseller, 2001, p. 420; V. RoPPO, Il Contratto cit., p. 441.

449 A. JUNQUEIRA DE AZEVEDO chama essa relação lógica entre as prestações de sinalagma indireto ((Parecer) Natureza Jurídica do Contrato de Consórcio cit., pp. 363 e ss.).

$450 \quad$ A identidade das prestações deve ser compreendida de maneira ampla, sem atentar para o objeto da prestação. Na sociedade, todos os sócios devem efetuar prestações idênticas no sentido de contribuírem para a formação do patrimônio societário. Mesmo no caso da entrada que consista em prestação de serviços, a identidade remanesce na atribuição patrimonial em favor da sociedade.

$451 \quad$ Cf. A. TOMASETti JR., Comentários cit., p. 12.

452 Cf. F. C. Pontes De MIRANDA, Tratado de Direito Privado, t. XXXVIII, § 4.185, n. 1.

453 Cf. M. Bernardes De Mello, Teoria do Fato Jurídico - Plano da Existência cit., p. 241.

454 Cf. T. AsCARELl, $O$ Contrato Plurilateral cit., p. 387.

455 Cf. M. Bernardes De Mello, Teoria do Fato Jurídico - Plano da Existência cit., p. 242. 
graus de intensidade da comunhão de fim refletida na relação entre as prestações, pois quando o escopo comum é muito intenso, a prestação de uma parte pode influenciar a posição das demais partes e até o contrato como um todo ${ }^{456}$. Nessas situações de altíssima intensidade da comunhão de fim, o sinalagma indireto e mediato também fica mais forte, pois o inadimplemento de uma parte pode colocar a perder a consecução do fim comum.

\subsubsection{Contratos de comunhão de escopo e contratos organizativos}

Muitas vezes os contratos de prestações dirigidas para a consecução de escopo comum são classificados como contratos associativos ${ }^{457}$, por meio do qual as partes contratuais organizam-se em relação ao desenvolvimento de uma atividade ulterior necessária para atingir o fim comum ${ }^{458}$. Entretanto, os contratos constitutivos de organizações compõem uma subcategoria dos contratos de prestações dirigidas para a consecução de escopo comum, subcategoria na qual a comunhão de finalidade assume especial relevo, sem esgotarem o conceito, pois podem existir contratos de escopo comum sem a constituição de organização ${ }^{459}$. Da mesma forma como a intensidade do escopo comum pode variar de contrato para contrato, as partes podem perseguir a finalidade por elas compartilhas com diferentes graus de institucionalização, sem a necessidade de constituição de uma organização em sentido estrito.

O objeto do contrato organizativo é a constituição de uma organização, conceituada juridicamente como a "coordenação da influência recíproca sobre atos" ${ }^{460}$. Não obstante, apesar de a organização ser efeito do contrato organizativo, ela está relacionada com a realidade social e econômica subjacente ao contrato, extrapolando os limites do mundo jurídico e assumindo um papel na sociedade, reconhecida como um ente, uma instituição, um sistema social com normas próprias para a realização de certos fins. Da mesma forma como o modelo dogmático de contrato, o conceito jurídico de organização deve ser

\footnotetext{
$456 \quad$ Cf. V. Roppo, Il Contratto cit., p. 442.

457 A expressão "contratos associativos" é bastante utilizada para designar os contratos constitutivos de organização, contudo deve ser evitada por ser um termo insuficiente para delimitar o fenômeno além de causar confusão com o conceito técnico jurídico de associação, que é efeito de um negócio jurídico plurilateral dito associativo. A noção de contrato associativo está relacionada com a constituição de uma estrutura comum institucionalizada, uma organização e, por tal razão, é mais coerente simplesmente falar em contrato organizativo ou contrato de organização.

458 Cf. T. AsCARELLI, O Contrato Plurilateral cit., pp. 396-397.

459 Cf. V. RoPPO, Il Contratto cit., pp. 441-442.

460 Cf. C. SAlomão Filho, O Novo Direito Societário, 4. a ed., São Paulo, Malheiros, 2011, p. 45.
} 
buscado no seio social, onde a organização é caracteriza pela existência de divisão de tarefas, distribuição de papéis, definição de sistema de autoridade, criação de um sistema de comunicação e desenvolvimento e aplicação de um sistema de retribuição e contribuição $^{461}$. O grau de institucionalização de cada organização dependerá da complexidade e da interdependência entre esses caracteres básicos do fenômeno organizativo, sendo totalmente possível encontrar organizações com dimensões incipientes e pouco evoluídas, sem perder a natureza de organização. No modelo jurídico dogmático, as diversas características das organizações são interpretadas e disciplinadas por meio de um regime tríplice, focado na existência de um ordenamento organizacional (orientado a disciplinar a finalidade comum, a estrutura de tomada de decisão e a relação entre os membros da organização entre si e com a organização), de um ordenamento patrimonial da organização (disciplinando a transferência de recursos entre a organização e os seus membros e criando regras para utilização desse patrimônio no exercício da atividade) e de um ordenamento da atividade organizacional (compreendendo as formas de direção dessa atividade, principalmente com relação à administração) ${ }^{462}$.

Com base na compreensão do modelo dogmático de contrato e nas diversas classificações dos contratos, será possível classificar e qualificar o contrato de participação em grupo de consórcio.

\subsection{Análise do contrato de participação em grupo de consórcios a partir das classificações contratuais propostas}

De acordo com a Lei n. ${ }^{\circ} 11.795 / 08$, o contrato de participação em grupo de consórcio classifica-se como "plurilateral de natureza associativa" cujo escopo comum consiste na "constituição de fundo pecuniário para propiciar a seus integrantes, de forma isonômica, a aquisição de bens ou serviços por meio de autofinanciamento”. A despeito

461 Cf. P. Bernoux, A Sociologia das Organizações, trad. port. Adão Carvalho, Porto, Rés, 2005, p. 116.

462 Cf. H. Wiedemann, Direito Societário, vol. I. Fundamentos, trad. port. E. Valladão Azevedo Novaes França, in E. Valladẽo Azevedo Novaes FrançA, Temas de Direito Societário, Falimentar e Teoria da Empresa cit., pp. 626-639, fala para fins das sociedades (que na, Alemanha diferentemente do atual regime Brasileiro, possuem amplo escopo e não estão limitadas apenas ao fim lucrativo), no ordenamento societário, no ordenamento patrimonial e no ordenamento da empresa. Exatamente, pela amplitude do conceito societário alemão, a tripartição porposta por H. WIEDEMANN goza de poder englobante tão amplo que pode ser transposta para análise da disciplina jurídica das organizações em geral, com óbvias adaptações terminológicas. 
da classificação legal, há quem entenda que o contrato de participação em grupo de consórcio classifica-se como contrato de prestações correspectivas celebrado entre a sociedade administradora do grupo de consórcio e cada consorciado individualmente, em razão do papel destacado desempenhado pela administradora de grupos de consórcio, responsável pela elaboração das cláusulas contratuais, do regulamento do grupo de consórcio, pela comercialização do grupo, pela escolha dos consorciados e pela gestão do fundo comum.

Por força das diversas dimensões do fenômeno contratual e do reconhecimento dessas dimensões no modelo dogmático de contrato, a análise do contrato de participação em grupo de consórcio depende da compreensão das manifestações sociais do contrato e da operação econômica concreta que é causa do contrato. Conforme foi possível depreender da evolução histórica e da dinâmica de funcionamento, desde as origens entre os servidores do Banco do Brasil até os dias atuais, a noção social de consórcio está intimamente relacionada à cooperação dos consorciados para a constituição de um fundo comum a ser periodicamente atribuído por sorteio a um dos consorciados, devendo o consórcio continuar em funcionamento até que todos os consorciados sejam sorteados e possam aplicar os recursos do fundo na compra de certo bem ou na retribuição pela prestação de determinado serviço. Sob a ótica da circulação da riqueza, existiam várias operações econômicas pontuais envolvendo a transferência de riqueza de cada consorciado para o fundo comum e a posterior transferência de riqueza desse fundo comum para um dos consorciados, coordenadas em uma única operação econômica englobante de cooperação. Com o passar do tempo, surgiram administradoras de grupos de consórcio, tomando a iniciativa de constituir os grupos e gerir o funcionamento contra o pagamento por cada consorciado de contraprestação na forma de taxa de administração. Trata-se de nova operação econômica com a transferência de riqueza em mão dupla, com o intercâmbio entre a utilidade da atividade da administradora e a utilidade dos recursos pecuniários transferidos pelos consorciados a título de taxa de administração. Sob a ótica da administradora, o mecanismo do consórcio como um todo passou então a ser desenvolvido em três etapas básicas ${ }^{463}$ : (1) captação de recursos junto ao público e formação dos grupos de consórcio; (2) administração dos recursos coletados; e (3) contemplação e utilização do crédito. Os problemas práticos na relação entre os consorciados e a administradora do grupo chamaram a atenção da doutrina, que passou a tratar a operação econômica entre 463 E. Fortuna, Mercado Financeiro - Produtos e Serviços, 18. a ed., Rio de Janeiro, Qualitymark, 2010, p. 958. 
consorciado e administradora como principal dentro do mecanismo do consórcio, até mesmo ignorando a operação econômica entre consorciados.

A Lei n. ${ }^{\circ}$ 11.795/08 procurou englobar o histórico social do consórcio e o desenvolvimento das operações econômicas ao longo do tempo por meio do conceito do contrato de participação em grupo de consórcio, fixando como núcleo conceitual do modelo de contrato de participação no grupo de consórcio os seguintes elementos: (1) os deveres de prestar parceladamente para a formação de patrimônio comum uma quantidade de moeda corrente em soma correspondente a percentual do valor de determinado bem ou serviço; (2) o dever de realizar sorteios periódicos para atribuição de crédito à prestação de transferência a propriedade sobre os recursos financeiros do patrimônio comum como pagamento do preço de compra de bem ou da retribuição pela prestação de serviço; (3) dever de transferir a propriedade sobre os recursos financeiros do patrimônio comum como preço de compra de bem ou retribuição pela prestação de serviço; (4) o poder de gerir os interesses e administrar o patrimônio comum; e (5) o dever de prestar a retribuição devida por causa da gestão e da administração do patrimônio comum. Por se tratarem de elementos completantes do núcleo do suporte fático do contrato de participação em grupo de consórcio, a ausência de qualquer dos elementos implica a insuficiência do suporte fático, a não incidência das normas jurídicas disciplinadoras do tipo contratual, e a consequente inexistência do contrato.

Partindo do núcleo conceitual do contrato de participação em grupo, o primeiro dever de prestar (= dívida) relaciona-se com a criação de "vínculos obrigacionais entre os consorciados" (art. 10, $\S 1 .^{\circ}$ da Lei n. $\left.{ }^{\circ} 11.795 / 08\right)$ e existência de um patrimônio comum, pois a prestação é destinada à formação desse patrimônio, o que pressupõe comunhão de finalidade e a possibilidade de multiplicidade de centros autônomos de interesses. O contrato de participação em grupo de consórcio é negócio jurídico patrimonial plurilateral caracterizado pela existência de uma finalidade comum (a obtenção de recursos para comprar certo bem ou contraprestar por determinado serviço) e pela possibilidade de existirem múltiplos lados exteriorizando a decisão negocial. Em razão da íntima relação entre negócios jurídicos plurilaterais e contratos de comunhão de escopo, o contrato de participação em grupo de consórcio configura-se então como contrato de prestações direcionadas para a consecução de fim comum. A pluralidade de prestações direcionadas para o fim comum permite identificar, de início, os consorciados como os devedores dessas prestações e, portanto, como partes do contrato de participação no grupo de consórcio. 
Importa apontar a unicidade do objeto da posição jurídica subjetiva passiva complexa imposta a cada consorciado, ou seja, a contribuição para o patrimônio comum é apenas una, integralmente correspondente ao percentual do valor do bem ou do serviço referenciado no contrato, mas esta prestação, até pela natureza do consórcio, é parcelada ao longo do prazo de eficácia do contrato. Assim, não é técnico falar na prestação mensal do consorciado para o patrimônio comum, exceto se entendido como prestação parcial da entrada para o patrimônio comum. As atualizações das parcelas em relação à valorização ou desvalorização do valor do bem ou do serviço decorrem do fato da dívida do consorciado consistir em dívida de valor, na qual a prestação consiste na transferência da propriedade de pecúnia cuja soma de valor corresponda ao valor de certo bem ou determinado serviço. Nas dívidas de valor, a moeda desempenha a função liberatória, pois é apenas pela entrega de moeda que o devedor pode cumprir sua prestação, mas ela não desempenha a função de servir como unidade de medida de valor, ficando tal função a cargo de algum bem ou serviço referenciado no contrato.

A identificação de eventual elemento organizativo no contrato de participação em grupo de consórcio depende da análise de seu objeto, cujo enunciado normativo do art. 10 parece indicar ser a constituição do patrimônio comum. Todavia, a compreensão do objeto do contrato passa pelo conceito tido como fundamental pela Lei $n .^{\circ} 11.795 / 08$ que é o grupo de consórcio, legalmente definido como uma "sociedade não personificada constituída por consorciados". Se o grupo de consórcio é um elemento fundamental do sistema de consórcios e o sistema é baseado no contrato de participação em grupo de consórcio, o objeto do contrato deve ser mais amplo do que apenas constituir o patrimônio comum, deve, necessariamente, englobar a constituição desse grupo. A posição oposta levaria a uma situação esdrúxula na qual o contrato de participação em grupo de consórcio cria um patrimônio comum dos consorciados e o conceito fundamental do grupo de consórcio é meramente presumido ou constituído como efeito acessório do contrato.

Observando o grupo de consórcios sob a lente dos fenômenos organizativos, identifica-se a presença em maior ou menor grau dos elementos típicos de uma organização enquanto um sistema composto por regras próprias para a influência recíproca de atos, notadamente os sistema de distribuição de papéis entre os consorciados contemplados, não contemplados e excluídos, a divisão de tarefas entre os consorciados e a sociedade administradora por meio dos representantes dos consorciados, sistemática clara de comunicação e de punições. Alguns elementos são fracos, como o sistema de 
autoridade, mas estão presentes em carga suficiente para permitir a caracterização do grupo de consórcio como organização, visto que a sociedade administradora ser dotada de autoridade para a atuação do dia a dia do grupo enquanto a assembleia geral extraordinária é titular de poderes para destituir a administradora e até encerrar o grupo de consórcio. De fato, o próprio contrato de participação em grupo de consórcio disciplina os três ordenamentos da organização, pois no âmbito do ordenamento organizacional, define a finalidade comum especificando qual o bem o serviço para o qual o patrimônio comum deve ser utilizado, atribui o status de consorciado, atribuindo posições jurídicas subjetivas ativas e passivas e estrutura a tomada de decisão nas assmbleias gerais, no campo do ordenamento patrimonial disciplina a transferência de recursos dos consorciados para o grupo de consórcio e cria os procedimentos e condições para o grupo de consórcio transferir recursos para o consorciado, e, por fim, o ordenamento da atividade se dá pela designação da administradora do grupo, com atribuição de funções internas e externas, e a delimitação de seus poderes. Consequentemente, é possível classificar o contrato de participação em grupo de consórcio consiste em contrato organizativo de prestações dirigidas à consecução de um fim comum.

Torna-se necessário então identificar se este ente organizativo é autônomo ou passível de qualificação dentro das espécies tradicionais de organizações, as associações ou as sociedades ${ }^{464}$. Como as organizações são decorrentes de contratos de comunhão de escopo, por meio dos quais os sujeitos organizam seus esforços e cooperam para o atingimento de certo fim, o conceito de fim comum é estrela polar dos fenômenos organizativos $^{465}$, pois os sujeitos de situações jurídicas figuram nas relações organizativas única e exclusivamente para atingir o fim comum que constitui e funcionaliza a organização.

Sob o aspecto do escopo comum, no ordenamento jurídico brasileiro, celebram o contrato organizativo societário "as pessoas que reciprocamente se obrigam a contribuir, com bens ou serviços, para o exercício de atividade econômica e a partilha, entre si, dos resultados" (Código Civil, artigo 981). Do ponto de vista estrutural, a finalidade comum "partilha do resultado" que decorre do "exercício de atividade econômica" é elemento completante do núcleo do suporte fático do contrato plurilateral societário, de modo que a não verificação desse fim comum no momento de celebração do contrato resulta na sua

464 As fundações foram excluídas do rol porque decorrem de negócio jurídico unilateral fundacional e o contrato de participação em grupo de consórcio é negócio jurídico plurilateral.

465 Cf. H. WIEDEMANn, Direito Societário cit., p. 625. 
inexistência do contrato e consequente ausência de sociedade, que é efeito do contrato societário $^{466}$, e, por isso, é possível afirmar que o escopo comum "partilha do resultado obtido pelo exercício de determinada atividade econômica" possui função constitutiva da própria sociedade ${ }^{467}$. Atente-se que o conceito de fim comum é amplo e somente pode ser compreendido por meio da decomposição do conceito em escopo-meio e escopo-fim. O escopo-meio ou objeto social é a atividade econômica explorada pela organização societária, enquanto o escopo-fim ou objetivo da sociedade consiste na obtenção de um resultado positivo decorrente da exploração do objeto social e na partilha desse resultado entre os todos os sócios (em outras palavras, o objetivo de toda sociedade é o lucro em sentido amplo $)^{468}$. A tutela do objetivo social lucrativo dá-se por várias maneiras, como a vedação geral ao pacto leonino ${ }^{469}$ consagrada pelo artigo 1.008 do Código Civil e imposição legal de que as sociedades por ações somente podem ser constituídas para exercer e explorar atividade lucrativa (artigo $2^{\circ}$ da Lei das Sociedades por Ações ${ }^{470}$ ). Na

466 J. H. PINTO FURTADO considera que o fim lucrativo é normalmente verificado no contrato societário, mas não configura elemento de existência propriamente dito. Como argumento, afirma que existem várias sociedades que não têm a lucratividade como finalidade precípua. Exemplifica com a sociedade holding cujo objetivo é concentrar e racionalizar participações societárias, sem lograr lucros diretamente, e com a sociedade cooperativa, na qual a vantagem é atribuída ao sócio e não à sociedade (Curso de direito das sociedades, $5^{\mathrm{a}}$ ed., Coimbra, Almedina, 2004, pp. 138 e ss). O argumento não convence, pois a concentração e racionalização das participações societárias feitas pela sociedade holding possui como critério racional o incremento da lucratividade global da sociedade e de suas controladas. Pelo argumento de J. H. PINTO FURTADO, uma sociedade puramente holding seria pouco atrativa do ponto de vista dos investidores no mercado de capital, já que sua lucratividade é indireta, mas pelo menos no mercado brasileiro, verifica-se uma grande quantidade de companhias cujo objeto consiste em controlar outras sociedades com elevado valor de mercado e liquidez, reflexo da percepção dos investidores com relação à lucratividade e geração de caixa livre por tais companhias.

467 Cf. H. WIEDEMANN, Direito Societário cit., p. 625.

468 Cf. E. Valladẽo de Azevedo e Novaes FranÇA - M. Vieira Von AdameK, “Affectio Societatis” cit., p. 43.

469 A vedação à sociedade leonina é princípio fundamental do direito societário desde os romanos, conforme menciona UlPIANO: "Aristo refere que Cassius deu um parecer segundo o qual uma sociedade não poderia ser combinada de modo a que um receberia todo o lucro e o outro suportaria o prejuízo; uma tal sociedade é chamada, habitualmente, sociedade leonina. Mós concordamos que uma tal sociedade é nula, pois um recebe o lucro e o outro nenhum lucro, mas antes o dano: tal tipo de sociedade é iniquíssimo, pela qual só se expecta dano e não também lucro” (D. 17.2.29.2). Anota A. MENEZES CORDEIRO que a ideia de sociedade leonina tem como origem a fábula de ESOPO denominada "o leão, o burro e a raposa". Reza a fábula: "Um leão, um burro e uma raposa, feito um pacto entre eles, andaram à caça e depois de terem capturado uma quantidade abundante de peças, o leão encarregou o burro de as dividir. O burro repartiu-a em três partes iguais e ofereceu aos companheiros o direito de escolher. Mas o leão, enfurecido com aquela repartição, rangendo os dentes perante a divisão, devorou-o e impôs à raposa repartir a presa. A raposa, pelo contrário, reuniu as três partes numa só e entregou tudo ao leão sem deixar nada de lado para si. $O$ leão, então, perguntou: 'Quem te ensinou a fazer divisões?' E prontamente a raposa: 'Ensinou-me a experiência do burro'. A fábula mostra que o perigo dos outros torna as pessoas mais cautelosas" (Manual de direito das sociedades, vol. I, Coimbra, Almedina, 2004, p. 531).

470 "Art. $2^{\circ}$ Pode ser objeto da companhia qualquer empresa de fím lucrativo, não contrário à lei, à ordem pública e aos bons costumes.

$\S 1^{\circ}$ Qualquer que seja o objeto, a companhia é mercantil e se rege pelas leis e usos do comércio.

$\S 2^{\circ} \mathrm{O}$ estatuto social definirá o objeto de modo preciso e completo. 
trilha da análise pelo escopo-fim lucrativo e do escopo-meio atividade econômica organizada, é possível verificar que a organização denominada grupo de consórcio não é uma sociedade orientada a explorar uma atividade para partilhar os resultados, pois a finalidade comum dos consorciados consiste na aquisição de determinado bem ou na obtenção de certo serviço por meio da coordenação e influência recíproca de atos de modo a formar um patrimônio comum cujos recursos serão dirigidos ao pagamento do preço de compra de bem ou da retribuição de serviços referenciados no contrato. Eventual argumento de que os consorciados partilham um resultado lucrativo decorrente da poupança das despesas ${ }^{471}$ com juros é falacioso, porque podem existir consórcios cuja taxa de administração superam economicamente os juros de um contrato de financiamento. Em tais casos, é possível aos consorciados saberem, ou pelo menos estimarem com bastante segurança, qual das modalidades é mais onerosa e, por uma série de circunstâncias concretas, decidirem pelo contrato de consórcio. O mecanismo do consórcio não é, necessariamente, mecanismo mais barato em relação às modalidades tradicionais de financiamento, mas se apresenta para muitas pessoas como o único instrumento para acessar o mercado de consumo, e tais pessoas não estão interessadas em obter um resultado positivo com a operação, sua preocupação é conseguir comprar o bem ou obter o serviço referenciado no contrato. Desse modo, carece ao grupo de consórcio o fim lucrativo típico das sociedades, cuja função constitutiva implica a inexistência de sociedade sempre que o objetivo da organização não for obter lucro por meio da exploração de atividade econômica e repartir, direta ou indiretamente, esse lucro entre os consorciados. Resumindo, o grupo de consórcio não é uma modalidade de organização societária.

Por princípio, uma vez excluída a espécie societária, restaria ao grupo de consórcio apenas a figura da associação ${ }^{472}$, cujo escopo comum consiste na perseguição de "fins não econômicos" (art. 53 do Código Civil ${ }^{473}$ ). Da mesma maneira como no caso das

$\S 3^{\circ}$ A companhia pode ter por objeto participar de outras sociedades; ainda que não prevista no estatuto, a participação é facultada como meio de realizar o objeto social, ou para beneficiar-se de incentivos fiscais".

471 Ao empregar o vocábulo resultado para conceituar a finalidade comum da sociedade, o Código Civil adota um conceito amplo de finalidade lucrativa, abrangendo toda vantagem econômica que repercute no patrimônio social e seja, em última instância, destinada aos sócios. Assim, considera-se resultado passível de partilha tanto o incremento do patrimônio inicial como a poupança de despesas, conforme explicam $\mathrm{F}$. FERRARA JR. e F. CORSI: "Così pure è indifferente che l'utile consista in un lucro, cioè in incremento patrimoniale, oppure in um risparmio di spesa" (F. FERRARA JR. - F. CORSI, Gli imprenditori e le società, 13. a ed. Milano, Giuffrè, 2006, pp. 227-228).

472 Obviamente, o grupo de consórcio não é um partido político ou uma organização religiosa, então tais espécies de organizações nem foram consideradas no texto.

473 "Art. 53. Constituem-se as associações pela união de pessoas que se organizem para fins não econômicos. 
organizações societárias, a perseguição de fins não econômicos possui uma função constitutiva, porque é elemento completante do núcleo do suporte fático do negócio jurídico plurilateral organizativo de associação, de maneira que a falta do fim comum impede a incidência da norma jurídica enunciada no art. 53 do Código Civil e não produz os efeitos constitutivos da organização. Apesar do enunciado legal empregar a locução "fins não econômicos", entende-se que o escopo comum das associações é a perseguição de um fim não lucrativo, pois o conceito de fim não econômico excluiria uma série de atividades econômicas que podem ser exploradas pela associação sem necessariamente serem lucrativas ${ }^{474}$. Com base nesse conceito amplo de fim associativo, que transforma a associação em um conceito organizativo captador de várias realidades, o grupo de consórcio até poderia ser considerado como uma associação não personificável, pois a atividade de adquirir o bem ou o serviço referenciado no contrato seria não lucrativa. Não obstante, mesmo com este conceito captatório de associação que poderia em tese englobar o grupo de consórcio, a verdade é que a Lei n. ${ }^{\circ}$ 11.795/08 criou uma nova espécie de organização, com uma finalidade especial e sujeita a um regramento próprio, diferenciado do regramento das associações, como fica evidente ao comparar os requisitos de validade do negócio jurídico plurilateral associativo com os requisitos de validade do contrato de participação em grupo de consórcio, ou pensar na impossibilidade de personificação do grupo de consórcio, excepcionando brutalmente o princípio da personificação das associações que é tão presente no ordenamento jurídico pátrio que leva alguns desavisados confundirem a associação com a própria personificação. Da mesma maneira como lei especial derroga lei geral, uma organização societária com finalidade especial e regramento próprio derroga uma organização societária de finalidade geral ${ }^{475}$, transformando o grupo de consórcio em uma espécie autônoma de organização, dotada de regras próprias.

\footnotetext{
Parágrafo único. Não há, entre os associados, direitos e obrigações recíprocos”.

474 Cf. F. Assis Alves, Associações, sociedades e fundações no Código Civil de 2002, São Paulo, Juarez de Oliveira, 2004, p. 38.

475 Ademais, a opinião ampliativa do escopo da associação está baralhando o escopo-meio, a atividade da associação, com o objetivo da associação, que é realizar fins idealísticos, altruístas, morais, religiosos, de interesse geral ou de benefício da comunidade. Associações podem exercer atividades econômicas organizadas e procurar obter um resultado positivo dessa atividade econômica, desde que isso sirva como um meio, um instrumento (escopo-meio) para que ela atinja um fim não econômico. Nessa acepção mais estrita, então, o grupo de consórcio não poderia ser considerado como uma organização associativa porque seu fim é econômico, a aquisição de bem ou obtenção de serviço no mercado, ainda que não seja lucrativo no sentido de repartição do benefício econômico. O benefício do consorciado no grupo de consórcio é sempre individual e varia de consorciado para consorciado não apenas com relação ao valor da categoria, mas também em decorrência do momento em que ele é contemplado e no momento em que utiliza o crédito.
} 
A menção legal ao grupo de consórcio como "sociedade não personificada" não foi uma tentativa classificatória por parte do legislador, mas o reconhecimento de que o grupo de consórcio, embora não seja pessoa jurídica, é sujeito de situações jurídicas, podendo figurar no polo ativo e passivo de relações jurídicas como titular de posições jurídicas subjetivas ativas e passivas, simples e complexas. Com efeito, ao mesmo tempo em que o enunciado legal define o grupo de consórcio como "sociedade não personificada", também atribui legitimação à sociedade administradora do grupo de consórcio para representar o grupo de consórcio, "em caráter irrevogável e irretratável, ativa ou passivamente, em juízo ou fora dele, na defesa dos direitos e interesses coletivamente considerados e para a execução do contrato de participação em grupo de consórcio, por adesão" (art. $3 .^{\circ}, \S 1 .^{\circ}$ da Lei n. ${ }^{\circ}$ 11.795/08). O tratamento legal foi além da atribuição de capacidade de parte prevista no art. 12, VII do Código de Processo Civil ${ }^{476}$, incluindo também a "representação" extrajudicial do grupo de consórcio, o que significa a atribuição de capacidade jurídica de direito material. Como demonstrou M. BERNARDES DE MELlo, no ordenamento jurídico brasileiro, o conceito de sujeito de direito e de pessoa não são sinônimos, pois podem existir sujeitos a quem o ordenamento jurídico imputa situações jurídicas e, principalmente, posições jurídicas subjetivas ativas e passivas, sem atribuirlhes a personalidade ${ }^{477}$. Quando o art. 12, VII do Código de Processo Civil atribui capacidade de ser parte ${ }^{478}$, cria a possibilidade para diversas organizações não personificadas, personificáveis ou impersonificáveis, serem titulares de posições jurídicas subjetivas, ativas e passivas, simples ou complexas, no âmbito de relação jurídica processual. Se há a possibilidade desses entes não personificados figurarem em relações jurídicas, então eles são dotados de capacidade jurídica e são sujeitos de situação jurídica. Sujeito, portanto, é todo ente a quem o ordenamento jurídico dotado da aptidão para ser titular de situações jurídicas, conforme conceitua M. BERNARDES DE MELLO:

\footnotetext{
476 "Art. 12. Serão representados em juízo, ativa e passivamente:

VII - as sociedades sem personalidade jurídica, pela pessoa a quem couber a administração dos seus bens".
477

Cf. Teoria do Fato Jurídico - Plano da Eficácia cit., pp. 141-183; A. TOMASETTI JR., A Parte Contratual cit., pp. 758-759.

$478 \quad$ Capacidade de ser parte é a possibilidade de ser parte em relação jurídica processual, qneuanto a capacidade processual consiste na possibilidade de agir pessoalmente em juízo. A capacidade de ser parte está para a capacidade civil como a capacidade processual está para a capacidade de agir. Cf. M. Bernardes de Mello, Teoria do Fato Jurídico - Plano da Eficácia cit., pp. 141-183; A. TomASETTI JR., A Parte Contratual cit. pp. 139-140.
} 


\begin{abstract}
"Sujeito de direito é todo ente, seja grupo de pessoas, sejam universalidades patrimoniais, a que o ordenamento jurídico atribui a capacidade jurídica $(=$ capacidade de direito) e, que, por isso, detém titularidade de posição como termo, ativo ou passivo, em relação jurídica de direito material (= ser titular de direito ou de dever, de pretensão ou obrigação, de ação ou de situação de acionado, de exceção ou de situação de excetuado) ou de direito formal (= ser autor, réu, embargante, opoente, assistente ou, apena, recorrente), ou, mais amplamente, de alguma situação jurídica" ${ }^{\text {"479 }}$.
\end{abstract}

A personalidade enquanto conceito jurídico consiste na atribuição pelo ordenamento jurídico da possibilidade ampla de ser um centro autônomo de imputação de situações jurídicas e de posições jurídicas subjetivas ativas e passivas, simples e complexas, patrimoniais e não patrimoniais, de titularidade desse centro de imputação de maneira orbital, formando uma esfera jurídica própria ${ }^{480}$. Nesse sentido, o grupo de consórcio pode não ser pessoa, não ser reconhecido como um centro autônomo de situações jurídicas, mas é, sem dúvida alguma, sujeito de situações jurídicas de direito formal e, por força de expressa prescrição legal, de direito material também. Significa isso que o grupo de consórcio pode figurar como parte em negócios jurídicos e nos polos de relações jurídicas como parte contratual em sentido substancial.

Como o grupo de consórcio pode figurar nos polos ativos e passivos de várias relações jurídicas, agrupar as posições jurídicas subjetivas ativas e passivas, simples e complexas, decorrentes de relações jurídicas obrigacionais e relações jurídicas reais $(=$ posições jurídicas subjetivas patrimoniais) de titularidade do grupo de consórcio facilita o pensamento e leva à conclusão lógica da existência de um patrimônio de titularidade do próprio grupo de consórcios. Não obstante, em tais situações, é comum abstrair o sujeito não personificado e focalizar nas relações entre os membros da organização, reconhecendo-se a presença de um patrimônio especial de titularidade em comum de todos os consorciados (art. 988 do Código Civil ${ }^{481}$ ). Esse patrimônio especial de titularidade dos múltiplos consorciados também pode ser denominado de patrimônio coletivo ${ }^{482}$ ou patrimônio em mão comum e corresponde ao conceito de Gesamthand do direito alemão, proveniente do princípio da vinculação em mão comum previsto no $§ 719$ do BGB, na qual a titularidade das posições jurídicas subjetivas patrimoniais ativas e passivas pertence em

\footnotetext{
479 Teoria do Fato Jurídico - Plano da Eficácia cit., p. 142, itálicos originais.

480 Em razão da maior amplitude do conceito de sujeito em comparação com a pessoa, emprega-se neste estudo o termo sujeito de situações jurídicas, ainda que se esteja tratando de pessoas naturais. Eventuais menções à pessoa sem maiores esclarecimentos são feitas no sentido comum, não técnico dogmático.

481 "Art. 988. Os bens e dívidas sociais constituem patrimônio especial, do qual os sócios são titulares em comum".

${ }_{482}$ Cf. C. A. Mota PInTo, Teoria Geral do Direito Civil, Coimbra, Coimbra, 1992, pp. 349 e ss.
} 
bloco, globalmente, ao conjunto de sujeitos titulares desse patrimônio ${ }^{483}$. DARCY BESSONE sustenta que a distinção entre a propriedade em mão comum e a copropriedade repousa na divisão ideal do direito ou na divisão ideal da coisa, acrescentando que "admitida a divisão da coisa em partes, ainda que abstratas, não haveria razão para negar-se a autonomia do direito de cada condômino" ${ }^{\text {,484 }}$. Nesse sentido, ordenamento jurídico brasileiro teria adotado o modelo individualista da copropriedade romana por quotas ideais, caracterizada pela atribuição de tantos direitos de propriedade sobre a coisa quantos sejam os condôminos, cujo conteúdo é a propriedade sobre toda a coisa, mas com exercício quantitativamente limitado pelo direito de propriedade do outro ${ }^{485}$. Com efeito, a copropriedade (titularidade simultânea de posições jurídicas subjetivas ativas de direito real sobre o mesmo bem, conceito mais amplo do que apenas a titularidade simultânea da propriedade plena ou domínio) é a regra no direito brasileiro, mas, como toda regra, admite situações excepcionais nas quais a há a atribuição comum da titularidade ${ }^{486}$ de posições jurídicas subjetivas ativas e passivas, como no caso claro do patrimônio especial. Normalmente, a doutrina traça o marco divisório entre a comunhão e a copropriedade na existência ou não de quotas ideais passíveis de livre disposição pelo titular ${ }^{487}$, noção que poderia ser utilizada para refutar a existência do patrimônio em mão comum dos consorciados. Tal argumento seria falho, no entanto, na medida em que no patrimônio coletivo inexistem quotas ideais sobre a coisa, como ocorre no caso da copropriedade, mas nada impede que existam quotas ideais do patrimônio comum como um todo unitário. Segundo K. LARENZ, enxergar quotas ideais do patrimônio coletivo no fenômeno da comunhão possui caráter conceitual e auxiliar, e dificilmente pode o jurista abrir mão dessa noção, visto que o comunheiro não pode dispor de fração sobre algum bem integrante do patrimônio comum, mas pode dispor, dentro dos limites permitidos pelo ordenamento jurídico, de sua fração no patrimônio coletivo como um todo unitário ${ }^{488}$. Pode ocorrer de as quotas ideais no patrimônio coletivo não aparecerem, ficando escondidas e não sendo

483 Cf. J. Lamartine CorrêA De Oliveira, A Dupla Crise da Pessoa Jurídica, São Paulo, Saraiva, 1979, pp. 62-28.

$484 \quad$ Cf. DARCY BeSSOne, Direitos Reais, São Paulo, Saraiva, p. 53.

485 Cf. DARCY BESSONE, Direitos Reais cit., p. 54.

486 Explica TORQUATO CASTRO que título "é, pois o nexo causal, ou relação, de pertinência de uma posição jurídica a uma pessoa cera; nexo jurídico que é expresso, de modo valorativo, no fato causa" (Cf. Teoria da Situação Jurídica em Direito Privado Nacional - Estrutura, Causa e Título Legitimário do Sujeito, São Paulo, Saraiva, 1985, p. 92). O autor faz a importante ressalva que "o título não se reduz ao fato, ainda que através do fato se expresse; e, por outro lado, advertir que título não é a própria posição do sujeito, cuja relação de pertinência, tão-só ele revela" (Cf. Teoria da situação jurídica cit., p. 94).

487 Cf. K. LARENZ, Derecho Civil - Parte General, trad. esp. Miguel Izquierdo y Macías-Picavea, EDERSA, 1978, p. 183.

488 Cf. K. LARENZ, Derecho Civil cit., pp. 183-184. 
passíveis de disposição até o momento de liquidação do patrimônio em comum, como no caso da meação do cônjuge ou do quinhão do herdeiro. A cessão da cota pelo consorciado importa, assim, transferência de uma qualificação jurídica e a consequente transferência da quota ideal Assim, é possível visualizar no condomínio pluralidade de situações jurídicas e pluralidade de sujeitos, enquanto na comunhão observa-se apenas pluralidade de sujeitos e unicidade da situação jurídica ${ }^{489}$. A pluralidade de situações jurídicas na copropriedade significa mais do que somente multiplicidade de posições jurídicas subjetivas ativas, pois pode representar pluralidade de relações jurídicas ${ }^{490}$, a depender da unicidade causal da copropriedade. Essa pluralidade também explica porque a copropriedade recai sobre bens específicos, sendo tratada de maneira individual ainda que os mesmos sujeitos sejam coproprietários de vários bens, enquanto a comunhão sempre engloba um patrimônio, quer o ativo patrimonial seja referido a apenas um bem, quer a vários. Ademais, a comunhão sempre exige um elemento finalístico, um escopo comum justificador do tratamento especial conferido a figura pela unicidade de posições jurídicas subjetivas, ativas ou passivas.

Para fins ilustrativos, a situação de copropriedade pode ser representada graficamente como uma das estruturas abaixo, a depender da existência de uma causa comum apta a gerar unicidade da relação jurídica ou não:

\section{Condomínio}

$\begin{array}{ll}\text { Polo Ativo Polo Passivo } & \end{array}$

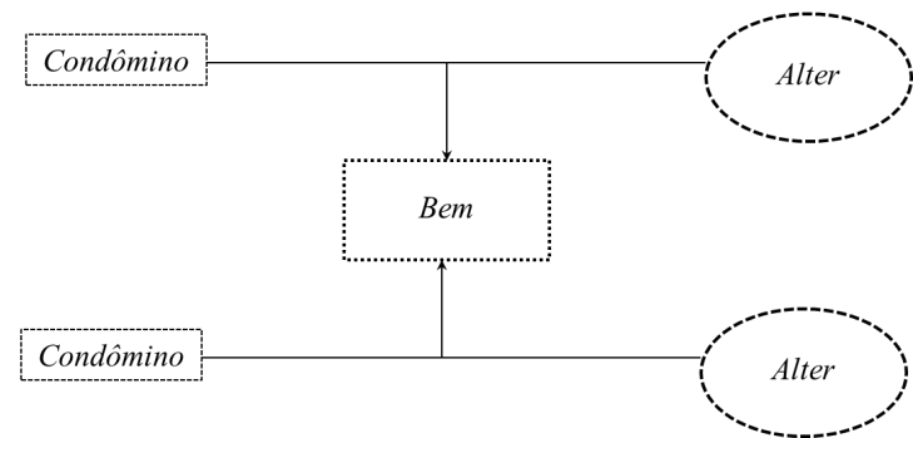

489 Cf. L. CAmargo Penteado, Direito das Coisas, 2. ${ }^{\text {a }}$ ed., rev., atual e ampl., São Paulo, Revista dos Tribunais, 2012, p. 454.

$490 \quad$ Cf. F. C. PONTES DE MIRANDA, Tratado de Direito Privado, t. XII, 2. a ed., Rio de Janeiro, Borsoi, $\S 1.273$. 
ou

\section{Condomínio}

Polo Ativo

Polo Passivo

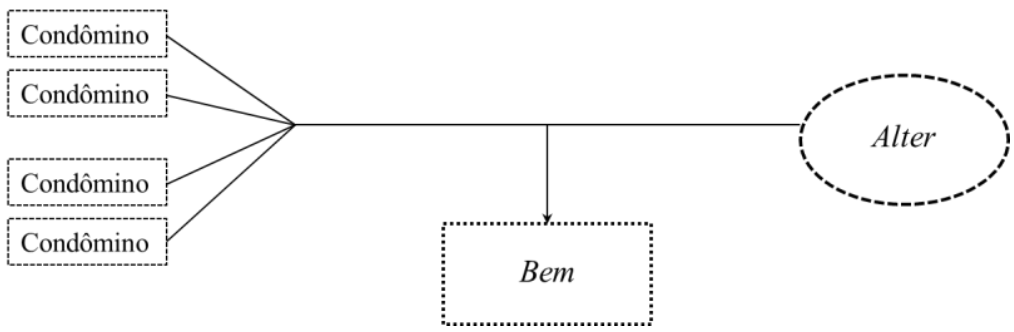

A relação jurídica no caso da comunhão pode ser representada conforme

\section{Comunhão}

Polo Ativo Polo Passivo

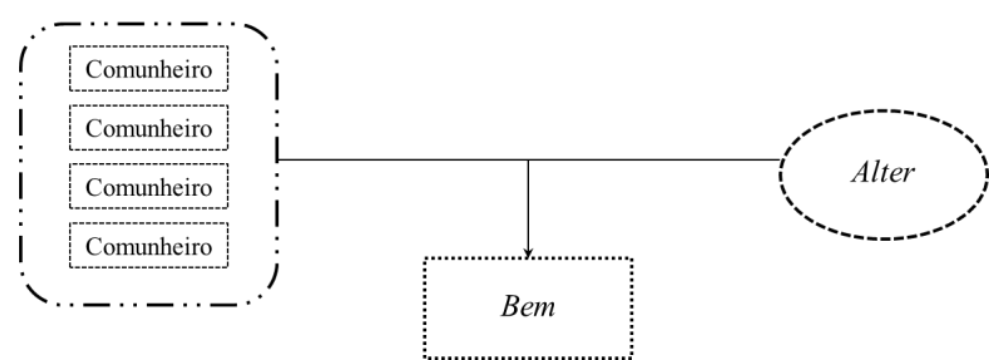

Identificar a existência de patrimônio em mão comum e do fenômeno organizativo traz impacto sensível na definição do papel da sociedade administradora do grupo de consórcio, pois uma das características da disciplina da organização consiste na definição de um centro diretivo e de gestão que atua como órgão administrativo da organização, denominando-se órgão o centro de imputação de poderes funcionais dentro de uma organização, compondo uma unidade organizacional mínima ${ }^{491}$. O órgão administrativo concentra uma série de poderes funcionais voltados à gestão, à tomada de decisões e à prática de atos que busquem o atingimento do fim comum da organização. Genericamente,

491 Cf. L. Brito CorreiA, Os Administradores de Sociedades Anónimas, Coimbra, Almedina, 1993, pp. 202-204. 
administrar consiste em tomar decisões quanto à aplicação de bens (em sentido amplíssimo) para a satisfação de necessidades, envolvendo, pois, decidir concretamente quais dentre os diversos interesses serão satisfeitos e quais bens serão utilizados para propiciar tal satisfação, por meio de uma atividade de escolha de objetivos últimos - planejamento a longo, médio ou curto prazo - ou de objetivos próximos, de organização, de provimento, de direção e de controle do agir de outro sujeito ${ }^{492}$.

Toda a organização precisa de um órgão administrativo mais ou menos institucionalizado, mas um mínimo de imputação de poderes funcionais é necessário, ou do contrário a organização jamais atingiria seu fim pela paralisia completa decorrente da necessidade de decisões dos membros para os assuntos mais corriqueiros. No caso do consórcio, o modelo legal atribui à sociedade administradora do grupo de consórcio o conjunto de poderes funcionais integrativos do órgão administração, transformando a relação entre grupo de consórcio e sociedade administradora do grupo em relação orgânica, com abstração de eventual negócio jurídico subjacente a essa relação, englobando, também, a também a administração do patrimônio em mão comum. A chamada taxa de administração, então, dentro do modelo legal, não é contraprestação por prestação de serviços ou por gestão e administração de interesses no âmbito de contrato de mandato ${ }^{493}$, consistindo em remuneração devida pelo grupo de consórcio à sociedade administradora do grupo de consórcio por sua atuação como órgão do grupo. No âmbito do Direito Civil, o modelo legal de contrato de participação em grupo de consórcio constitui relação orgânica entre o grupo de consórcio e a sociedade administradora, dotada de poderes funcionais para mover o patrimônio coletivo do grupo, limitando-se as relações jurídicas entre consorciados e sociedade administradora de consórcio aos deveres laterais decorrentes da boa-fé objetiva no âmbito do contato social negocial entre o consorciado e administradora, que faz uma espécie de intermediação entre os vários consorciados para formar o grupo de consórcio $^{494}$.

492 Cf. L. BRITO CORREIA, Os Administradores cit., p. 59.

493 O mandato é o contrato por meio do qual um sujeito fica recebe poderes (não necessariamente poderes de representação) para administrar interesses alheios, podendo a atividade administrativa tomar parte com ou sem legitimação para o mandatário movimentar a esfera jurídica do mandante (Cf. F. C. PONTES DE MIRANDA, Tratado de Direito Privado, t. XLIII, § 4.675-§ 4.676). Assim, é tecnicamente incorreto falar em contrato de prestação de serviços de administração ou de gestão, pois a prestação positiva de fato administração é a prestação típica do contrato de mandato, cuja especialização exclui a incidência das normas jurídicas sobre prestação de serviços.

$494 \quad$ Fala-se no âmbito do Direito Civil porque a ausência de relação entre consorciado e sociedade administradora não pré-exclui, a qualificação jurídica da administradora do grupo como fornecedora para fins de aplicação do Direito do Consumidor. A atuação ativa da sociedade administradora do grupo de consórcio 
Subjacente à noção de órgão encontra-se a ideia de parte do corpo, pois o órgão não representa a organização, mas ele a faz presente como se fosse boca, olhos, ouvidos e mãos da organização, é um presentante e não um representante ${ }^{495}$. Do reconhecimento do grupo de consórcio como um sujeito de situações jurídicas e do papel da sociedade administradora do grupo como presentante do grupo, evidencia-se o equívoco prático de atribuir à sociedade administradora a propriedade sobre os recursos do grupo, que são tratados como patrimônio separado, ou constituir em favor dela as garantias dos consorciados contemplados que utilizaram o crédito. A propriedade é de titularidade do grupo de consórcio e as garantias beneficiam o grupo de consórcio, e qualquer atribuição de propriedade à sociedade administradora só pode ocorrer de incompreensão dos conceitos e deve ser tratada como uma aquisição pautada na fidúcia, aquisição fiduciária no sentido estrito do termo e não no sentido de propriedade condicional para garantia de dívida, conforme adotado pelo Código Civil. Não se diga que a ausência de personalidade impede a aquisição de propriedade ou a constituição da garantia em favor do grupo de consórcio, pois o grupo de consórcio é sujeito de situações jurídicas relacionadas à consecução do escopo comum. O negócio jurídico por meio do qual o grupo de consórcio referenciado em serviços adquirisse a propriedade de bem imóvel sem relação com o fim comum seria inexistente por falta de capacidade jurídica. Mas o depósito em contacorrente dos recursos aportados pelos consorciados e as garantias constituídas, todas elas devem ser realizadas em nome do grupo de consórcios, dotado de capacidade jurídica para figurar em tais relações jurídicas.

De todo o exposto, é possível delimitar que as partes (= centro autônomo de interesses) do contrato de participação em grupo de consórcio, de acordo com o modelo legal, são, única e exclusivamente, os diversos consorciados, que celebram, por adesão, contrato organizativo de prestações dirigidas à escopo comum. Dentro desse modelo legal, a sociedade administradora não é parte do contrato, mas figurante anexa que aceita a nomeação para o desempenho das funções administrativas do grupo de consórcio.

É fundamental ressaltar que essa relação orgânica entre a sociedade administradora do grupo de consórcio e o próprio grupo de consórcio faz parte do modelo legal, mas não se coaduna com o modelo social do funcionamento do grupo de consórcio. Apesar de o

na formação do grupo e captação dos consorciados pode ser suficiente para considera-la fornecedora de serviços, mas tal questão não é objeto deste estudo, do qual expressamente foi excluída a análise da matéria consumerista.

495 Cf. A. Tomasetti JR., A Parte Contratual cit., p. 759. 
consórcio nascer no âmbito da atividade criadora dos sujeitos no exercício de seu poder de autorregramento e passar a ser paulatinamente aceito e regulado pelo Direito, a Lei $\mathrm{n}^{\circ}$ 11.795/08 não apenas correu atrás da prática social como, em alguns pontos, ultrapassou-a, indo sensivelmente à frente do que os agentes do setor estavam acostumados. A relação entre sociedade administradora e grupo de consórcio é um exemplo claro dessa ultrapassagem, pois apesar da possibilidade de presentação orgânica por parte da sociedade administradora, tal modalidade ainda não é muito presente na prática. Na verdade, sob o nome de contrato de participação em grupo de consórcio, são celebrados dois negócios jurídicos coligados, o contrato organizativo do grupo de consórcio e um contrato de mandato entre o consorciado e a sociedade administradora do grupo. Em razão desses dois contratos, surgem duas relações jurídicas diferentes, a relação jurídica organizativa, por meio da qual os consorciados ficam adstritos a prestar para o patrimônio coletivo do grupo de consórcio, e a relação jurídica de mandato constituída entre a sociedade administradora do grupo de consórcio e cada um dos consorciados individualmente. Nesta relação jurídica de mandato, a taxa de administração não é paga pelo grupo de consórcio, mas sim pelo consorciado diretamente para a administradora, que possui a função de representar todos os consorciados na administração do patrimônio coletivo.

O próximo passo para a compreensão do contrato de participação em grupo de consórcio consiste na análise sumária do seu processo de formação, focalizando principalmente na dinâmica da proposta de participação e da constituição na primeira assembleia geral do grupo.

\subsection{Processo de conclusão do contrato de participação em grupo de consórcio}

No tocante ao processo de conclusão do contrato de participação em grupo de consórcio, a Lei n. ${ }^{\circ}$ 11.795/08 inovou ao criar a figura da proposta de participação no grupo de consórcio, por meio da qual o interessado requer à sociedade administradora a sua admissão no grupo, convertendo-se a proposta de participação no contrato de participação no grupo a partir da aprovação da administradora (art. 10, § 3. ${ }^{\circ}$ ). A lógica subjacente ao dispositivo está relacionada à necessidade da sociedade administradora analisar o perfil do cliente, seu risco de crédito e sua adequação àquele determinado grupo. Comentando o dispositivo, A. MALFATTI tece duras críticas a essa inovação que 
aparentemente inverte o papel do consorciado enquanto aderente e por isso assevera que a proposta de participação já é o próprio contrato, vinculando a sociedade administradora desde logo:

\begin{abstract}
“A 'proposta de participação' não se diferencia do contrato. Trata-se de uma oferta que, uma vez aceita pelo consumidor, produz efeitos contratuais e vincula o fornecedor, na forma do art. 30 do CDC. Ou seja, não deve haver diferença conceitual entre proposta de participação e contrato de consórcio. A proposta aceita (expressamente) pelo consumidor vincula a administradora de consórcio, que colocou a cota de consórcio no mercado de consumo. O contrato existe e, preenchidos os requisitos legais (formação e conteúdo), também é válido" ${ }^{\text {"496. }}$.
\end{abstract}

A. MALFATTI também critica a necessidade de realização de assembleia geral para a constituição do grupo de consórcio, pois se esse fator de eficácia do contrato de participação no grupo de consórcio, se não estiver evidente para o consumidor no instrumento de contrato que lhe é apresentado, deve ser considerado como desnecessário para a constituição do grupo de consórcio, in verbis:

\begin{abstract}
"Primeiro requisito legal para a validade da cláusula de eficácia criada pelo art. 10 , $\S 3 .^{\circ}$ e $4 .^{\circ}$, da Lei 11.795/2008: ser prévia e efetivamente informada ao consumidor. Do contrato de participação em grupo de consórcio, seja ele denominado "proposta de participação" ou de qualquer outro nome, deverá constar expressamente a disposição sobre a referida condição. Em outras palavras, se a administradora de consórcio não informar adequada, prévia e efetivamente o consumidor, por meio de cláusula contratual com destaque sujeitar-se o negócio a uma condição não deixa de ser uma limitação do direito do consumidor - e de maneira ostensiva no instrumento, torna-se inafastável a seguinte conclusão: o contrato desde logo produz efeitos, considerando-se constituído o grupo de consórcio, independente da realização da primeira assembléia de consorciados" ${ }^{497}$
\end{abstract}

As críticas de A. MALFATTI estão relacionadas com a transmissão de informações claras para o consumidor, devendo ser considerando o contrato existente, válido e eficaz imediatamente em caso de não cumprimento satisfatório do dever de informar e proteger o consumidor imposto à sociedade administradora na qualidade de fundadora do grupo de consórcio. Essas críticas devem ser avaliadas e compreendidas a partir do reconhecimento do contrato de participação em grupo de consórcio como contrato de prestações dirigidas à

496 Cf. O Contrato de Consórcio e o Direito do Consumidor, após a Vigência da Lei 11.795/2008, Revista de Direito do Consumidor, $\mathrm{n}^{\circ}$ 70, São Paulo, RT, 2009.

497 Cf. O Contrato de Consórcio e o Direito do Consumidor, após a Vigência da Lei 11.795/2008, Revista de Direito do Consumidor, ${ }^{\circ}$ 70, São Paulo, RT, 2009. 
consecução de escopo comum, celebrados entre os consorciados por um processo de conclusão sucessiva de contrato entre ausentes ${ }^{498}$, sem perder de vista que, no modelo legal, a sociedade administradora do grupo de consórcio somente figura de forma anexa no contrato na qualidade de "fundadora" do grupo de consórcio e nomeada para exercer a função de órgão do grupo de consórcio.

No processo de conclusão sucessiva dos negócios jurídicos unilaterais, e com grande relevo no caso do contrato de participação em grupo de consórcio, a sociedade administradora atua como fundadora, pois não só é ela quem elabora o contrato e o regulamento do grupo de consórcio, como também recebe e organiza as adesões dos interessados. A atuação da fundadora é essencial para a conclusão do contrato, pois as partes não dificilmente se encontrariam sem a intermediação de alguém que esteja efetivamente interessado na celebração do contrato e na constituição do grupo de consórcio. Com efeito, as adesões são dirigidas à fundadora, no caso, à sociedade administradora, que toma todas as atitudes necessárias para lograr a conclusão do contrato e a constituição do grupo de consórcio.

Ao analisar o processo sucessivo de formação das sociedades por ações a partir de contrato organizativo, T. ASCARELLI concluiu que a subscrição realizada pelos interessados possui a natureza de oferta de adesão dirigida aos fundadores e cabem a eles (fundadores) aceitarem ou rejeitaram essa oferta dentro dos parâmetros fixados no prospecto ${ }^{499}$. Esta concepção da subscrição ou adesão como oferta dirigida aos fundadores repercutiu na Lei n. ${ }^{\circ} 11.795 / 08$, pois a figura da proposta de participação nada mais é do que uma oferta de cada interessado em aderir ao contrato de participação em grupo de consórcio. A atuação da sociedade administradora neste caso é instrumental, sendo titular de legitimação para aceitar ou rejeitar a oferta por todos os consorciados e atuais consorciados. Essa noção da subscrição como oferta de adesão é artificial e cria maiores inconvenientes práticos do que facilita o funcionamento da conclusão sucessiva do contrato. Na realidade, as chamadas “propostas de participação" são verdadeiros negócios jurídicos unilaterais de adesão ao contrato organizativo, cuja eficácia depende da aprovação da sociedade administradora do grupo de consórcio ${ }^{500}$. Após a aprovação do negócio pela administradora, a eficácia do negócio jurídico unilateral de adesão irá fundir-se com a eficácia dos demais negócios jurídicos unilaterais de adesão dos demais aderentes, mas ainda não irá formar o contrato

\footnotetext{
498 Cf. T. AsCARELl, O Contrato Plurilateral cit., pp. 390-392.

499 Cf. T. AsCARELLI, O Contrato Plurilateral cit., pp. 391-393.

$500 \quad$ Cf. F. C. Pontes DE MIRANDA, Tratado de Direito Privado, t. L, § 5.299.
} 
de participação em grupo de consórcio ${ }^{501}$. Nesse momento, a fusão da eficácia dos diversos negócios jurídicos unilaterais de adesão irá gerar apenas uma situação jurídica de vinculação dos aderentes, já há relação jurídica e os aderentes são titulares de posições jurídicas subjetivas passivas elementares de sujeição à conclusão do contrato de participação em grupo de consórcio na primeira assembleia geral. Ou seja, a realização da assembleia geral não é mero fator de eficácia do contrato de participação em grupo de consórcio, mas verdadeiro elemento completante do núcleo do suporte fático do contrato $^{502}$

Sem dúvida, nesta sociedade líquida orientada para o consumo, o consumidor encontra-se em situação de vulnerabilidade e deve ser protegido com medidas enérgicas, mas tais medidas devem ser ponderadas com outros valores do ordenamento jurídico, como a coerência interna dos modelos dogmáticos. A sociedade administradora de grupos de consórcio deve informar de forma ampla o consumidor interessado (1) de que sua adesão está condicionada à aprovação da sociedade administradora após análise de perfil; e (2) que conclusão do contrato e a constituição do grupo de consórcio somente ocorrerão na primeira assembleia geral após serem obtidas adesões em número suficiente para garantir a viabilidade econômica do grupo. Em caso de descumprimento do dever de informar a respeito da necessidade de aprovação da adesão do interessado, é plenamente cabível a atribuição de eficácia direta a tal negócio jurídico unilateral de adesão, mesmo sem a aprovação da sociedade administradora. Vale notar que a atribuição de eficácia direta ao negócio jurídico de adesão não implica a celebração do contrato ou a constituição do grupo, mas apenas a vinculação do aderente e da sociedade administradora. Por outro lado, a falta de comunicação quanto à necessidade da assembleia geral para a conclusão do contrato e constituição do grupo não pode resultar na formação do grupo de consórcio por dois motivos básicos. Primeiro, a garantia de viabilidade econômica do grupo e a realização da assembleia geral são elementos do núcleo do suporte fático do contrato porque fazem parte do modelo de conclusão sucessiva de contratos de escopo comum e não podem ser substituídos simplesmente porque faltou uma informação no contrato. Segundo, porque considerar constituído o grupo antes de atingir o número necessário de adesões para garantir a viabilidade não protege o consumidor, mas coloca-o em uma situação de grande exposição a risco, visto que o grupo não possui condições financeiras para funcionar corretamente. Em tal situação de falta do dever de informação, a sociedade 
administradora deve responder ao consumidor pelos prejuízos causados por seu descumprimento.

Uma lacuna na disciplina do contrato de participação em grupo de consórcio é a fixação de responsabilidades específicas para a sociedade administradora enquanto desempenhando o papel de fundadora dos grupos de consórcio. Dentro do modelo legal de contrato de participação em grupo de consórcio, é esta atuação da sociedade administradora que poderá qualifica-la como fornecedora de serviços para eventual aplicação do Direito do Consumidor. Além disso, é possível trazer por analogia as normas atinentes aos fundadores das sociedades por ações, que respondem por dolo e culpa por todos os prejuízos causados pelos atos causados anteriormente à constituição da companhia e por violação de normas jurídicas cogentes.

\subsection{Consentimento por adesão e contrato por adesão}

Exceto quando o negócio jurídico plurilateral é celebrado entre todas as partes presentes, o processo de conclusão sucessiva do negócio invariavelmente resulta em uma ou algumas partes apenas aderirem ao conjunto de cláusulas negociais, sem efetiva negociação dessas cláusulas. Apesar de o consentimento se realizar por adesão nesses casos, nem todo o negócio jurídico plurilateral constitutivo de relações jurídicas patrimoniais pode ser classificado como do contrato por adesão. O modelo clássico de contrato é pautado na ampla discussão do conteúdo contratual por cada uma das partes, racionais, em pé de igualdade, e dotadas de ampla liberdade contratual, na qual as partes trocam propostas, acordando paulatinamente em pontos específicos, até que uma das partes aceita a proposta completa da outra, uma verdadeira "luta de vontades" embates nunca são idênticos, ainda que os lutadores sejam os mesmos, cada contrato é único, com um conteúdo particular e próprio que o diferencia dos demais contratos ${ }^{504}$, pautado no pressuposto da igualdade formal entre os contratantes ${ }^{505}$. Na atual sociedade líquida, verifica-se um fenômeno recorrente ao redor de todo o globo: a estandardização das relações sociais e, consequentemente, das relações contratuais ${ }^{506}$, o que afeta

\footnotetext{
503 I. Galvão Telles, Manual dos Contratos em Geral cit., p. 311.

504 I. Galvão Telles, Manual dos Contratos em Geral cit., p. 311

505 J. M. ANTUNES VARELA, Das Obrigações em Geral cit., vol. I, p. 252.

506 As considerações que seguem são inspiradas nos apontamentos constantes em E. RoPPO, O Contrato
} 
diretamente a empresa, que por natureza já tem como função funcionar como uma alternativa ao mercado a partir de um nexo organizado de contratos com objetivo de reduzir os custos de negociação (transction costs) de cada contrato individualizado ${ }^{507}$ ao organizar a produção, a circulação e o consumo de bens ou serviços. Destarte, surge uma necessidade incontrolável de uniformizar as relações contratuais em seu conteúdo, o que permite uma série de contratações indefinidas com uma quantidade também indefinida de sujeitos, resultando no crescimento constante da sociedade como um instrumento de eficiência de organização do modo de produção. Com efeito, a ideia é a racionalização da atividade econômica a partir da predisposição antecipada de um esquema contratual complexo e uniforme, aplicado indistintamente a todas as relações jurídicas de uma mesma categoria ou tipo. Nessa ótica, as características pessoais da contraparte deixam de ser relevantes. Quem desejar manter relações contratuais com o predisponente precisará aceitar o esquema contratual, reduzindo-se a discussão e a negociação a poucos aspectos comerciais. Cabe-lhe apenas o papel passivo de aceitar, ou melhor, aderir em bloco às cláusulas previamente dispostas, de modo unilateral e impositivo.

A utilização de contratos com regramentos uniformes, predispostos, rígidos e genéricos acelera radicalmente a conclusão dos contratos, reduz os custos de negociação e serve como um parâmetro para a organização interna e estratégia da empresa no setor de atuação. Ademais, a estandardização dos contratos facilita a execução dos vários contratos, pois a quantidade de contratos celebrados e de longa duração é tão absurda que seria economicamente inviável para a grande empresa monitorar e executar cada contrato individual com suas especificidades próprias, o que permite, também, a racionalização quantitativa, pois o conjunto de contratos de determinado tipo ou categoria pode ser mais facilmente avaliado na contabilidade empresarial. Na prática, começam a surgir formulários e modelos que contém um clausulado geral, denominado de "condições gerais de contratação" ou "cláusulas contratuais gerais". Tais cláusulas são incorporadas aos contratos concretos por referência direta, e, não raramente, nem sequer são apresentadas ao aderente.

cit., p. 311-319.

Cf. R. H. COASE, The Nature of the Firm, in Economatica, vol. 4, 1937, pp. 386-405; R. H. COASE, The Problem of Social Cost, in Journal of Law and Economics, vol. 3, 1960, pp.1-44. ). Estes custos de negociação (ou transaction costs) consideráveis são fruto do arcabouço institucional no qual a operação é realizada e da tecnologia adotada para efetivar a operação (Cf. D. NORTH, Institutional Change and Economic Performance, Cambridge, Cambridge University Press, 1990, p. 34). 
O contrato por adesão é marcado pela ausência de efetiva discussão e negociação entre as partes ${ }^{508}$, visto que uma das partes formula sua proposta de contrato cabendo à outra parte simplesmente decidir se aceita ou não a proposta. Em um primeiro momento, a estrutura segue o padrão legal da proposta de uma parte e a aceitação ou rejeição, mas há um dado na dinâmica entre as partes que muda sensivelmente a situação. Ao contrário do que ocorre na conclusão tradicional do contrato, no contrato por adesão o ofertado não tem a alternativa de apresentar uma nova proposta, tendo em vista que o proponente original não está interessado em negociar. Desse modo, os ofertados

\footnotetext{
"são apenas livres de aderir ao modelo, padrão ou cláusula que lhes é oferecida, ou de a rejeitar, não de discutirem ou alterarem o conteúdo da proposta. Não há aqui, por conseguinte, a livre discussão entre as duas partes, que salurtamente costumava preceder a fixação do conteúdo do contrato e da qual nascia a seivajurídica do negócio bilateral”, ${ }^{, 509}$.
}

J. Matos Antunes Varela conceitua contrato por adesão como "aquele em que um dos contraentes [...], não tendo a menor participação na preparação e redacção das respectivas cláusulas, se limita a aceitar o texto que o outro contraente oferece, em massa, ao público interessado" ${ }^{, 510}$.

Ao que tudo indica, a expressão "contrato de adesão" foi cunhada por R. SALEILLES que, ao estudar o Código Civil alemão, apontou a existência de uma espécie contratual marcada pelo "predomínio absoluto de uma só vontade, que, agindo como vontade unilateral, dita a sua lei, não já a um indivíduo mas a uma comunidade indeterminada" ${ }^{\text {,11. }}$. Essa locução faz referência à estrutura de conclusão do contrato, que depende da mera adesão de uma das partes. Mais tecnicamente, assim, deve-se falar em contrato por adesão, entendendo que o consentimento se faz "por adesão". É por isso que se costuma diferenciar os chamados contratos de adesão - contratos em que há uma posição monopolística do contratante que fixa unilateralmente a regulamento contratual - dos contratos por adesão, que abrangem as várias modalidades de contratos em que há uma parte dotada de grande poder negocial.

\footnotetext{
508 Cf. W. Monteiro - C. A. Dabus Maluf - R. B. TAvares Silva, Curso de direito civil, vol. V, direitos das obrigações - $2^{a}$ parte, 38. ${ }^{a}$ ed., São Paulo Saraiva, 2011, p. 50; I. GALVÃo TELlES, Manual dos Contratos em Geral cit., p. 311; J. M. ANTUNES VARELA, Das Obrigações em Geral cit., vol. I, p. 252 509 Cf. J. M. Antunes VARELA, Das Obrigações em Geral cit., vol. I, p. 253, itálicos originais.

510 Cf. J. M. Antunes VARELA, Das Obrigações em Geral cit., vol. I, p. 252-253.

511 Cf. R. SAlEILles, De la Déclaration de Volonté - Contribution à l'étude du Code Civil Allemand,
} Paris, F. Pchon-Successeur, 1901, p. 129. 
No caso dos contratos organizativos com processo de conclusão sucessiva, I. GALVÃo TELLES entende não serem, em princípio, verdadeiros contratos por adesão, pois esta categoria é reservada "para os casos em que a atitude passiva de mera adesão se apresente como algo estrutural e constante, no âmbito de um número indeterminado de contratos, e não como qualquer coisa de contingente ou esporádico" ${ }^{\text {,512 }}$. Deveras, os elementos caracterizados do contrato por adesão podem, assim, ser apontados como ${ }^{513}$ : (1) superioridade do poder negocial de um dos contratantes, que se coloca em posição de ditar as cláusulas contratuais; (2) unilateralidade das cláusulas, concebidas apenas pelo contratante forte, normalmente visando apenas seu interesse próprio; e (3) a invariabilidade do texto negocial, que deve ser aceito em bloco pelo aderente.

Pensando nos contratos de participação em grupo de consórcio, modalidade de contrato de prestações dirigidas à consecução de fim comum, seria possível, de início, excluí-los da órbita do regramento dos contratos por adesão, pois embora o consentimento seja por adesão, a celebração esporádica de um contrato como esse não estaria inserida no fenômeno da estandartização das relações contratuais. Não obstante, a sociedade administradora de consórcios não atua como fundadora e figura como órgão administrativo em apenas um único contrato de participação em grupo de consórcio, mas elabora as cláusulas, forma os grupos e atua como administradora em inúmeros contratos e grupos de consórcio, utilizando cláusulas padronizadas, predispostas e rígidas. Embora não seja efetivamente parte dos contratos, ela possui interesse econômico direto e profissional nos contratos e nos grupos de consórcio, caracterizando uma modalidade de contrato no qual não só o consentimento ocorre por adesão, mas há também um processo estruturado e constante de uniformização de relações contratuais.

Finalizadas as considerações a respeito das matérias controvertidas dos contratos de participação em grupos de consórcio, é possível passar para a classificação e qualificação do contrato. 


\subsection{Classificação do contrato de participação em grupo de consórcio}

Do exposto, é possível determinar que na classificação dos contratos pela função econômica, o contrato de participação em grupo de consórcio afigura-se como um contrato de colaboração recíproca para a obtenção de um fim comum. Sob o critério da existência de elemento tradição ou entrega como completante do suporte fático do contrato, trata-se de um contrato consensual, sofrendo a incidência das normas jurídicas pela fusão dos efeitos dos negócios jurídicos unilaterais de adesão conjugado com a realização da assembleia geral de constituição que certificar a viabilidade econômico-financeira do grupo de consórcio. No plano da validade, apresenta-se como contrato não solene, porque não existe norma jurídica impositiva de qualquer tipo de forma, principalmente a forma escrita. Há uma série de cláusulas de inserção obrigatória no contrato e cuja inobservância pode acarretar a invalidação da adesão de algum consorciado e até do contrato como um todo, mas não se trata de exigência quanto à forma do negócio jurídico plurilateral, e sim com relação ao seu conteúdo. A instrumentalização do contrato de participação em grupo de consórcio é uma necessidade lógica e prática em razão da sua complexidade, mas não imposição de norma jurídica sobre forma. Quanto a critério da onerosidade, o contrato de participação em grupo de consórcio impõe a todas as múltiplas partes a realização de atribuição patrimonial em favor do grupo de consórcio, revertendo ulteriormente em atribuição patrimonial do grupo de consórcio para cada um dos consorciados. Pelo critério da classificação a partir do risco jurídico e econômico da prestação, afigura-se como contrato comutativo com equilíbrio normal de risco entre as diversas. Com base no critério da correspectividade das prestações, consiste em contrato de prestações direcionadas para a consecução de fim comum. Por último, o contrato de participação em grupo de consórcio é um contrato organizativo, cuja eficácia típica consiste na constituição de uma organização autônoma denominada grupo de consórcio.

Em síntese, no modelo legal, o contrato de participação em grupo de consórcio é negócio jurídico plurilateral celebrado entre os consorciados por adesão, consensual, não solene, oneroso, comutativo, de prestações convergentes à consecução de um fim comum e constitutivo de uma organização autônoma denominada de grupo de consórcio e reconhecida como sujeito de situações jurídicas. 


\subsection{Impossibilidade de qualificação do contrato de participação em grupo de consórcio}

Qualificar um contrato é um juízo predicativo, consistindo na atribuição a certo contrato concreto a correspondência a este ou aquele tipo em virtude qualidades típicas, por meio de um processo de relacionação entre o conteúdo contratual efetivamente negociado pelas partes e o ordenamento jurídico com seus modelos típicos ${ }^{514}$. A proposta de qualificação do contrato de participação em grupo de consórcio decorria do entendimento da doutrina contemporânea que considera o contrato como atípico, por falta de regulação completa de seus efeitos jurídicos, que devem ser reconduzidos a outros tipos contratuais, especialmente a sociedade e o mandato ${ }^{515}$.

A análise do contrato de participação em grupo de consórcio revelou uma disciplina jurídica bastante completa e complexa, capaz de preencher as lacunas nas decisões das partes quando necessário e de prescrever condutas e efeitos jurídicos diversos, incluindo a constituição de uma organização, a atribuição da capacidade jurídica limitada a essa organização, um patrimônio em mão comum e um órgão de administração titular de uma série de poderes funcionais. Nesse sentido, o contrato de participação em grupo de consórcio é objeto de disciplina suficiente para ser considerado nominado e legalmente típico, de maneira que não cabe falar em processo de qualificação desse contrato. Por outro lado, uma vez admitida a tipicidade do contrato de participação em grupo de consórcio, o juízo predicativo de atribuição de correspondência a partir de qualidades próprias e tipicamente verificadas. Operações de consórcio plenamente típicas, nas quais a sociedade administradora figura como fundadora e posteriormente como administradora da organização desenvolvida para a formação de patrimônio comum a ser aplicado no pagamento do preço de compra de bem ou na retribuição pela prestação de serviço. Maior complexidade surge em situações nas quais o mecanismo é adotado entre sujeitos sem a participação da sociedade administradora dos recursos. Seria isso um contrato de participação em grupo de consórcio? Com base no processo tipológico é possível afirmar que sim, pois embora muito importante no modelo legal, a figura da sociedade administradora não é essencial ao tipo contratual, que possui por qualidade típica o patrimônio comum e a atribuição periódica de crédito a um membro do grupo.

514 Cf. P. PAES DE VASCONCELOS, Contratos Atípicos cit., p. 170.

515 Cf. F. UlhoA Coelho, Curso de Direito Civil cit., vol. III, cap. 39, item 3.3.3. 


\section{CONCLUSÃO}

A palavra consórcio, desde seu uso na Roma pré-clássica, está intimamente associada com a união de pessoas ou bens que compartilham a mesma sorte, o destino comum. Foi um nome apropriado para a iniciativa dos servidores do Banco do Brasil no início dos anos 1960 que buscavam fugir das altas taxas de juros e da inflação elevada no período por meio da criação de um fundo comum e o sorteio em favor de um dos membros a cada mês. Não é possível saber se o mecanismo teve alguma inspiração nos antigos clubes de mercadoria ou no Tanomoshi-Ko, mas em pouco o mecanismo de consórcio tornou-se uma febre nacional, e acabou sofrendo com grande sucesso quando algumas pessoas aventureiras começaram a atuar entre os administradores de grupos de consórcios.

O contrato de participação em grupo de consórcio é um exemplo evidente do processo da absorção pelo legislador dos tipos sociais dos contratos criados pela criatividade dos sujeitos, pois paulatinamente o modelo regulatório foi mudando da simples permissão, para o controle da atividade das administradoras e, por fim, da disciplina de um sistema de consórcios. O objetivo claro da Lei n. ${ }^{\circ}$ 11.795/08 foi consolidar as bases para um todo mais amplo, um verdadeiro sistema de consórcios, isto é, um complexo de elementos que interagem entre si, de modo que um determinado elemento apresenta um comportamento específico em relação a outro elemento, tal comportamento é tão específico que só existe na relação entre ditos elementos. Por força dessa interação particular entre cada um dos elementos, há uma relação de interdependência, condicionamento, coordenação e subordinação entre os vários elementos do sistema, o que implica a modificação de todo o sistema quando um elemento é modificado ${ }^{516}$. Isso

516 Cf. L. VON BERTALANFFly, General System Theory - Foundation, Development and Applications, New York, George Braziller, 1969, pp. 55-56; M. E. BALleSTERo AlvarEZ, Organização, sistemas $e$ métodos, v.1, São Paulo, McGraw-Hill, 1990, p. 17. No âmbito do Direito, G. LuMIA sustenta que a ideia de ordenamento jurídico como sistema seja caracterizado pela existência de pluralidade de elementos e pela existência de regras de composição disciplinadoras das relações entre os diversos elementos e a modificação interna do sistema, em razão das relações de condicionamento entre os elementos, o conjunto não constitui apenas um agregado, mas uma totalidade que é muito maior do que a soma dos elementos considerados individualmente. Como cada elemento condiciona os demais, a modificação de cada propriedade do sistema acarreta a alteração de todas as suas partes (Elementos da Teoria e Ideologia do Direito, trad. de Denise Agostinetti, São Paulo, Martins Fontes, 2003, p. 65 e s). N. BobBIO esclarece que o ordenamento jurídico é um sistema social normativo complexo, decorrente da existência de normas primárias de conduta dos sujeitos e normas secundárias que disciplinam a identificação de normas dentro do sistema, a modificação de normas do sistema e a aplicação de normas do sistema (Normas primarias y normas secundárias, in Contribución a la Teoría del Derecho, Madrid, Editorial Debate, 1990, pp. 317-332). Em sentido contrário, vide C. WILHELM CANARIS, para quem o ordenamento jurídico não é um sistema de normas, mas uma ordem teleológica de princípios gerais do Direito, qualificada pela abertura e mobilidade (Pensamento Sistemático e Conceito de 
significa que existem dois sistemas disciplinados pela Lei n. ${ }^{\circ} 11.795 / 08$, o consórcio enquanto um sistema envolvendo as sociedades administradoras de grupos de consórcio e os grupos de consórcio, e o sistema composto pelos diversos consórcios espalhados pelo país.

Ambos os sistemas encontram no contrato de participação no grupo de consórcio sua estrela polar, seu nascente e também o seu norte. Dentro do modelo dogmático brasileiro, contrato consiste em negócio jurídico bilateral ou plurilateral, concluído em função de uma operação econômica, que constitui, modifica, regula e extingue relações jurídicas patrimoniais. Nesse sentido, o contrato de participação em grupo de consórcio consiste em negócio jurídico plurilateral celebrado entre os consorciados por adesão, consensual, não solene, oneroso, comutativo, de prestações convergentes à consecução de um fim comum e constitutivo de uma organização autônoma denominada de grupo de consórcio.

O grupo de consórcio é efeito do contrato de participação em grupo de consórcio e consiste em espécie autônoma de organização cujo fim comum é concentrar recursos pecuniários a serem atribuídos periodicamente aos consorciados para a compra do bem ou obtenção do serviço referenciado no contrato. O grupo de consórcio é sujeito de situações jurídicas e deveria ser o titular dos bens e das garantias formalizadas. Assim, de lege ferenda, deveria ser reconhecido no âmbito administrativo, em especial a Secretaria da Receita Federal do Brasil e do Banco Central a autonomia do grupo de consórcio, permitindo-lhe constar em cadastras e registros em nome próprio.

O patrimônio do grupo de consórcios é disciplinado pelas regras da comunhão, que admitem a divisão de quotas sobre o patrimônio, e não sobre os bens individualmente. A transferência da cota de consorciado implica assim a transferência do status de membro da organização e cessão da quota ideal no patrimônio coletivo.

No modelo legal, a administradora de consórcios atua como órgão do grupo de consórcios e não figura em relação jurídica individual com os consorciados. Eventual responsabilidade da administradora em relação aos consorciados individualmente deve ser apurada a partir de sua atuação como fundadora do grupo no processo de conclusão sucessiva do contrato de participação em grupo de consórcio.

Sistema na Ciência do Direito, trad. port. C. A. Menezes Cordeiro, 3. ${ }^{a}$ ed., Lisboa, Calouste Gulbenkian, 2002). 
Ademais, do ponto de vista do equilíbrio econômico, percebe-se que o mecanismo de consórcios poderia, a exemplo do Tanomoshi-Ko, admitir em caráter facultativo em cada grupo a possibilidade dos primeiros contemplados pagarem juros aos últimos contemplados. Trata-se de mecanismo de justiça, pois do ponto de vista econômico, o último contemplado experimento um custo de oportunidade altíssimo e do ponto de vista financeiro ele efetivamente financia os primeiros contemplados. 


\section{REFERÊNCIAS BIBLIOGRÁFICAS}

ABRÃo, Carlos Henrique, Do consórcio, Rio de Janeiro, GZ, 2010.

AcAdemia Brasileira De Letras, Vocabulário Ortográfico da Língua Portuguesa (VOLP), 5. ${ }^{\text {a }}$ ed., Rio de Janeiro, Global, 2009.

AleXANDER, Larry - SHERwIn, Emily, Demystifying Legal Reasoning, Cambridge Introductions to Philosophy and Law, Cambridge, 2008.

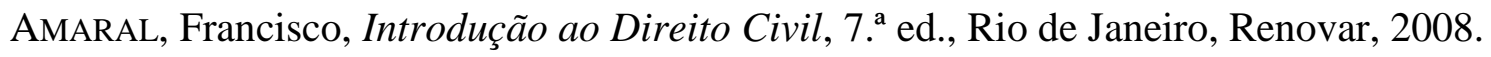

Antunes Varela, João de Matos, Das Obrigações em Geral, vol. I, 10. a ed. rev. e atual., Coimbra, Almedina, 2002.

ARAngio-Ruiz, Vincenzo, La società in Diritto Romano, Napoli, Jovene, 1950.

Ascenção, José de Oliveira , Direito Civil, v. 2, Ações e fatos jurídicos, 3. a ed., São Paulo, Saraiva, 2010.

Associação Brasileira DAS AdMinistradoras De ConsóRcio, Consórcio - uma poupança programada, São Paulo, 2008.

. Consórcio - A realidade de um Sonho Brasileiro, São Paulo, ABAC, 2005.

AzEVEDo, Antônio Junqueira de, Negócio Jurídico - Existência, Validade e Eficácia, São Paulo, Saraiva, 4. ${ }^{\mathrm{a}}$ ed., 2002.

. (Parecer) Natureza Jurídica do Contrato de Consórcio (sinalagma indireto).

Onerosidade excessiva em contrato de consórcio. Resolução parcial do contrato, in Novos Estudos e Pareceres de Direito Privado, São Paulo, Saraiva, 2009.

BAuman, Zigmund, Amor líquido - sobre a fragilidade dos laços humanos, trad. port. Carlos Alberto Medeiros, Rio de Janeiro, Zahar, 2004.

- O mal-estar da pós-modernidade, trad. port. Mauro Gama, Cláudia Martinelli Gama, Rio de Janeiro, Zahar, 1999, p

. Vida para o consumo - a transformação das pessoas em mercadoria, trad. port. Carlos Alberto Medeiros, Rio de Janeiro, Zahar, 2008, p

Bernardes De Mello, Marcos de, Teoria do fato jurídico - Plano da Existência - 12. ed., São Paulo, Saraiva, 2003.

. Teoria do fato jurídico - Plano da Existência - 18. a ed., São Paulo, Saraiva,

2012. 
Teoria do Fato Jurídico - Plano da Eficácia - 1. ${ }^{a}$ parte, 8. ${ }^{a}$ ed., São Paulo, Saraiva, 2013.

BetTI, Emilio, Teoria Geral do Negócio Jurídico, trad. port. Fernando de Miranda, t. I, Coimbra, Coimbra, 1969.

.Teoria geral do negócio jurídico, trad. port. Ricardo Rodrigues Gama, v. I, Campinas, LZN, 2003.

Beviláqua, Clóvis, Código Civil dos Estados Unidos do Brasil. $11^{\mathrm{a}}$ ed., Paulo de Azevedo, Rio de Janeiro, 1958.

BiancA, Massimo, Condizioni generali di contrato, , v. 2, t. 2, In Realtà socieale ed effetività della norma: scritti giuridici, Milano, Giuffré, 2002p. 475.

Bluteau, Raphael, Vocabulario Portuguez \& Latino - aulico, anatomico, architectonico, v. 2, Coimbra, Collegio das Artes da Companhia de Jesu, 1728.

BobBIO, Norberto, Teoria da Norma Jurídica, trad. port. Fernando Pavan Baptista e Ariani

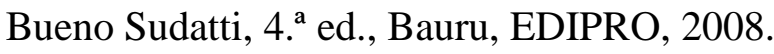

Bogen, James, Woodward, James, Saving the Phenomena, Philosophical Review, 97.

Camargo Penteado, Luciano de, Efeitos contratuais perante terceiros, São Paulo, Quartier Latin, 2007.

Capanema De Souza, Sylvio, Responsabilidades Contratuais em face do Ato Declaratório n. 1 da SRF/MF, in ASSOCIAÇÃo BRASILEIRA DE AdVOGAdOS, Doutrina em Consórcio, vol. I, t. I, Hermes, 1990.

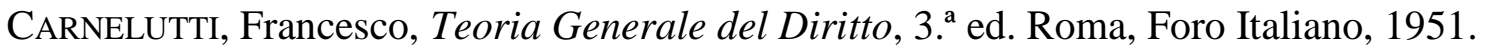

CAVAlCANTI, Flávio de Queiroz Bezerra, Natureza jurídica do grupo de consórcio, IOB Repertório de Jurisprudência: Civil, Processual, Penal e Comercial, nº 16, Ago., 1992.

Cavichiolli Carmona, Paulo Afonso, O Consórcio Imobiliário Como Instrumento de Intervenção Urbanística, Belo Horizonte, Fórum, 2007.

Chaves, Antonio, Tratado de direito civil, vol. II, t. II, 3. a ed., São Paulo, Revista dos Tribunais, 1984.

COASE, Ronald Harry, The Nature of the Firm, in Economatica, vol. 4, 1937.

.The Problem of Social Cost, in Journal of Law and Economics, vol. 3, 1960.

Comparato, Fabio Konder, Estudos e Pareceres de Direito Comercial, Rio de Janeiro, Forense, 1978.

Comissão de RedaÇão, Consortium, in Enciclopédia Saraiva de Direito, v. 18, São Paulo, Saraiva, 1978. 
Cruz, Ricardo - RosA, Daniel de - KeISI, Minami, Almanaque do Centenário da Imigração Japonesa no Brasil, São Paulo, Escala, 2008.

Dabus Maluf, Carlos Alberto, As condições no direito civil: doutrina e jurisprudência, Rio de Janeiro, Forense, 1983.

DEKLE, Robert - KoICHI, Hamada, On the Development of Rotating Credit Associations in Japan, Economic Development and Cultural Change, vol. 49, n. 1, 2000.

Del Chiaro, Emile, Le Contrat de Société en Droit Privé Romain Sous la République et au Temps des Jurisconsultes Classiques, Paris, Sirey, 1928.

Dicionário Houaiss da Língua Portuguesa, Rio de Janeiro, Objetiva, 2009.

DINIZ, Maria Helena, Tratado teórico e prático dos contratos, vol. IV, $6^{\mathrm{a}}$ ed., São Paulo, Saraiva, 2006.

DOMINGUeS DE ANDRADE, Manuel A., Teoria geral da relação jurídica, v. I e II, Coimbra, Almedina, 2003.

DUGUIT, León, Las transformaciones generales del derecho (público y privado), Buenos Aires, Editorial Heliasta, 1975.

ENGISCH, Karl, Introdução ao pensamento jurídico, trad. port. João Baptista Machado, 9a ed., Lisboa, Fundação Calouste Gulbenkian, 2004.

FERguson, Niall, The Ascent of Money - a Financial History of the world, New York, Penguin, 2009.

FLÜME, Werner, Allgemeiner Teil des Bürgerlichen Rechts, vol. II, Das Rechtsgeschäft, 4. ${ }^{\mathrm{a}}$ ed., Berlin - Heidelberg - New York - London - Paris - Tokyo - Hong Kong - Barcelona - Budapest, Springer, 1992.

Franco Neto, Ary Azevedo, in Lamy Filho, Alfredo - Bulhões Pedreira, José Luiz Direito das Companhias, vol. II, Rio de Janeiro, Forense, 2009.

FranÇA, Erasmo Valladão de Azevedo e Novaes, A Sociedade em Comum, São Paulo, Malheiros.

FrAnÇA, Erasmo Valladão de Azevedo e Novaes - VON ADAMEK, Marcelo Vieira, "Affectio Societatis": um Conceito Jurídico Superado no Moderno Direito Societário pelo 
Conceito de "Fim Social", in FrançA, Erasmo Valladão de Azevedo e Novaes -Temas de Direito Societário, Falimentar e Teoria da Empresa, São Paulo, Malheiros, 2009.

FreUd, Sigmund, O mal-estar na civilização, 2. ${ }^{\text {a }}$ ed., Coimbra, Relógio D’Água, 2008.

GAIO, Instituições - direito privado romano, trad. e notas J. A. Segurado e Campos, Lisboa, Calouste Gulbenkian, 2010.

Galgano, Francesco, Il Negozio Giuridico, Milano, Giuffrè, 2002.

Galvão Telles, Inocêncio, Manual dos Contratos em Geral, 4. ${ }^{a}$ ed., Coimbra, Coimbra Editora, 2002.

Garcia-Amigo, Manuel, Condiciones generales de los contratos, Madrid, Revista de Derecho Privado, 1969.

Gomes, Orlando, Contratos de adesão: condições gerais dos contratos, São Saulo, Revista dos Tribunais, 1972.

GraU, Eros Roberto, O Direito Posto e o Direito Pressuposto, São Paulo, Malheiros, 1996.

HART, Herbert Lionel Adolphus, $O$ conceito de direito. Trad. port. A. Ribeiro Mendes. $4^{\mathrm{a}}$ ed., Lisboa, Fundação Calouste Gulbenkian, 2005.

HondIUS, Edwoud H. Il controlo sulle condizioni generali nel diritto olandese, in BIANCA, Massimo (coord.), Le condizioni generali di contrato, Milano, Giuffré, 1981.

JENSEN, Michael Cole - William Henry Heckling, The Nature of Man, Journal of Applied Corporate Finance, vol. 7, n. ${ }^{\circ}$ 2, 1994.

JOSSERAND, Louis, L'essor moderne Du concept contractuel, In, Recueil d'etudes sir Le sources du droit en l'honneur de François Geny, s.d. t. II. Paris, Recueil Sirey.

KELSEN, Hans, Teoria pura do direito. Trad. port. João Baptista Machado. São Paulo: Martins Fontes, 2003. 
KEYNES, John Maynard, The General Theory of Employment, Interest and Money, New York, Martino Fine Books, 2011.

KING, Jeffrey C., Tense, Modality, and Semantic Value, Philosophical Perspectives, 17, 2003.

LarenZ, Karl, Derecho de Obligaciones, trad. esp. Jaime Santos Briz, t. II, Madrid, Editorial Revista de Derecho Privado, 1958.

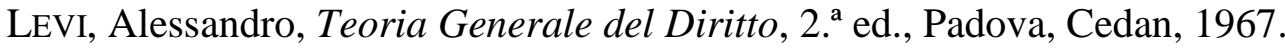

LEvine, Ross, Finance and Growth - Theory and Evidence, in Aghion, Philippe - Durlauf Steven, Handbook of economic growth, v.1, Amsterdam, North-Holland, 2006.

LEwIS, David Kellogg, On the Plurality of Worlds, Oxford, Blackwell, 1986.

Lima Marques, Cláudia, Os Contratos de Crédito na Legislação Brasileira de Proteção do Consumidor, Revista de Direito do Consumidor, vol. 18, Abr., 1996.

LimONGi FrançA, Rubens, Autonomia da vontade, in Enciclopédia Saraiva de Direito, vol. IX, São Paulo, Saraiva, 1978.

LôBo, Paulo Luiz Netto, Condições gerais dos contratos e cláusulas abusivas, São Paulo, Saraiva, 1991.

LoPes FerreIRA, Fabiano, Consórcio e Direito - Teoria e Prática, Belo Horizonte, Del Rey, 1998

LÓPEZ, Juan José Martin, El ámbito de aplicación de la ley sobre condiciones generales de la contratación, In, CARLO, Ubaldo Nieto et al, Condiciones generales de la contratación e cláusulas abusivas, Válladoilid, Lex Nova, 2000.

Loss, Louis, Securities Regulation, vol. I, 2. ${ }^{\text {a }, ~ B o s t o n, ~ L i t t l e ~ B r o w n, ~} 1961$.

LumiA, Giuseppe, Elementos da teoria e ideologia do direito, trad. port. Denise Agostinetti, São Paulo, Martins Fontes, 2003.

MAIA, Felipe Fernandes Ribeiro, O Sistema de Consórcio Financeiro na Lei 11.795/2008, Revista de Direito Bancário e do Mercado de Capitais, vol. 47, Jan / 2010. 
Consórcio financeiro - o Sistema e o Pedido de Restituição do Consorciado na Falência da Administradora, Dissertação de mestrado, Belo Horizonte, Universidade Federal de Minas Gerais, 2007.

Malfatti, Alexandre David, O Contrato de Consórcio e o Direito do Consumidor, após a Vigência da Lei 11.795/2008, Revista de Direito do Consumidor, $\mathrm{n}^{\circ}$ 70, São Paulo, RT, 2009.

MANKIW, Nicholas Gregory, Introdução à economia, 5. ${ }^{a}$ ed., trad. port. Allan Vidigal Hastings, Elisete Paes e Lima, ver. téc. Carlos Roberto Martins Passos, Manuel José Nunes Pinto, São Paulo, Cengage Learning, 2009.

Masset Lacombe, Francisco José, Dicionário de negócios - mais de 6.000 termos em inglês e português, São Paulo, Saraiva, 2009.

MElo, Diogo L. Machado de, Cláusulas contratuais gerais, contratos de adesão, cláusulas abusivas e o código de 2002, São Paulo, Saraiva, 2008.

MessineO, Francesco, Doctrina General del Contrato, trad. esp. R. O. Fontanarrosa, S. Sentís Melendo, M. Volterra, t. I, Buenos Aires, Europa-America, 1952.

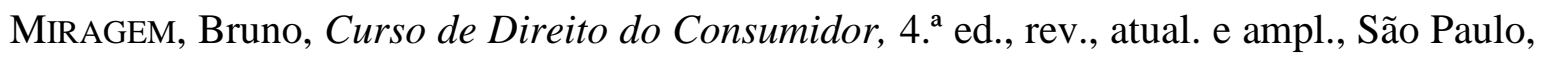
Revista dos Tribunais.

MonteIRO, António Pinto, Contratos de adesão e cláusulas contratuais gerais: problemas e soluções, Revista Trimestral de Direito Civil, Rio de Janeiro, Padma, ano 2, v. 7.

MonteIRo, Washington de Barros - Dabus Maluf, Carlos Alberto; Silva, Regina Beatriz Tavares da. Curso de direito civi-direitos das obrigações ,2a parte. 38. ${ }^{\mathrm{a}}$ ed., São Paulo, Saraiva, 2011.

Moraes Silva, Antonio, Diccionario da Lingua Portugueza - Recompilado dos Vocabularios Impressos ate Agora, e Nesta Segunda Edição Novamente Emendado e Muito Acrescentado, por Antonio de Moraes Silva, 2. ${ }^{a}$ ed., vol. I, Lisboa, Typographia Lacerdina, 1813,

MoraIS, Fernando, Corações Sujos - A história da Shindo Renmei, São Paulo, Companhia das Letras, 2000. 
MotA, Maurício, As condições gerais dos contratos no direito brasileiro, In, Questões de direito civil contemporâneo, Rio de Janeiro, Elsevier, 2008.

Mota PInTo, Carlos Alberto da, Teoria geral do direito civil. $3^{\mathrm{a}}$ ed., Coimbra, Coimbra Editora, 1999.

. Cessão da posição contratual, Coimbra, Almedina, 2003.

Mota Pinto, Paulo Cardoso Correia da, Interesse Contratual Negativo e Interesse Contratual Positivo, v. 1, Coimbra, Coimbra, 2008.

NorTh, Douglass Cecil, Institutions, Institutional Change and Economic Performance, 27. ${ }^{a}$ ed., New York, Cambridge University Press, 2009.

NOVEMSKY, Nathan - DHAR, Ravi, Goal fulfillment and goal targets in sequential choices, in Journal of Consumer Research, vol. 32, dez. 2005.

O'BrIEn, David James - FugitA, Stephen S., The Japanese American Experience, Bloomington, Indiana University Press, 1991.

Orfale Giacomini, Daniel, A Devolução das Quantias Pagas pelos Consumidores Desistentes e Excluídos dos Contratos de Consórcio à Luz da Lei 11.795/08 e do Código de Defesa do Consumidor, Dissertação de Mestrado, Pontifícia Universidade Católica de São Paulo, 2010.

Pais de Vasconcelos, Pedro, Contratos Atípicos, 2. ${ }^{a}$ ed., Coimbra, Almedina, 2009.

PACHUKANIS, Evgeni Bronislávovich, Teoria geral do direito e o marxismo, trad. port. Paulo Bessa, Rio de Janeiro, Renovar, 1989.

PERLINGIERI, Pietro, Perfis do direito civil: introdução ao direito civil constitucional, trad. port. Maria Cristina De Cico, $3^{\mathrm{a}}$ ed., Rio de Janeiro, Renovar, 2007.

PetiT, Eugene, Tratado Elementar de Direito Romano, trad. port. J. L. Custódio Porto, adap. R. Rodrigues Gama, Campinas, Russell, 2003.

Pimentel Nobre, Lionel, Armani, Flavio Augusto Dadalto, Alguns Comentários sobre a Nova Sistemática dos Consórcios no Brasil, Revista dos Tribunais, vol. 746, Dez., 1997.

Pontes De MiRAnda, Francisco Cavalcanti de, Tratado de Direito Privado, vol. I, II, III, XXV, XXXVIII, XLIX, L e LI, 2. a ed., Rio de Janeiro, Borsoi.

Tratado das ações, t. I, São Paulo: Revista dos Tribunais, 1970. 
Radbruch, Gustav, Filosofia do Direito, trad. port. L. Cabral de Moncada, 6. ${ }^{\text {a }}$ ed., Coimbra, Arménio Amado, 1997.

RizZARDo, Arnaldo, Contratos, 5. ${ }^{\text {a }}$ ed., Rio de Janeiro, Forense, 2005.

Rodrigues Penteado, Mauro, Anotações sobre o consórcio de empresas, Dissertação, Faculdade de Direito da Universidade de São Paulo, São Paulo, 1978.

Roppo, Enzo, O Contrato, trad. port. A. Coimbra e M. J. C. Gomes, Coimbra, Almedina, 2009.

RopPo, Vincenzo, Il Contrato, Milano, Giuffrè, 2001.

SÁ, Almeno de, Cláusulas contratuais gerais e directiva sobre cláusulas abusivas, 2. ed., Coimbra, Almedina, 2005.

SALEILles, Raymond, De la déclaration de volonté, contribution à l'étude Du Code Civil Allemand, Paris, F. Pchon-Successeur, 1901.

SAVIGNY, Friedrich Karl von. Sistema del derecho romano actual. Trad. esp. Jacinto Mesía e Manuel Poley. Granada: Comares, 2005.

Senise LisboA, Roberto, Manual de direito civil, vol. III, 3. ${ }^{a}$ ed., São Paulo, Revista dos Tribunais, 2005.

Silva Pinto, Luiz Maria da, Diccionario da Lingua Brasileira por Luiz Maria da Silva Pinto, natural da Provincia de Goyaz, Na Typographia de Silva, 1832.

Silveira Marchi, Eduardo C., Guia de Metodologia Jurídica - Teses, Monografias e Artigos, 2. ed., São Paulo, Saraiva, 2009.

SMITH, Adam, The wealth of nations, New York, Random House, 1994.

Sousa FigueIREdo, Alcio Manoel de, ABC do Consórcio - Teoria e Prática, 5. ${ }^{\circ}$ ed., Curitiba, Juruá, 2009.

SuPIOT, Alain, Homo juridicus" - Ensaios sobre a Função Antropológica do Direito, trad. port. M. Ermantina de Almeida Prado Galvão, São Paulo, Martins Fontes, 2007.

TrABUCCHI, Alberto, Istituzioni di diritto civile, 40. ed., Milano, CEDAM, 2009. 
TomasetTi JR., Alcides, Teoria Geral do Direito Privado, mimeo, São Paulo, 2004. .Comentários ao Art. $1 .^{o}$, in J. DE OllVEIRA, Comentários à Lei de Locação de Imóveis Urbanos - Lei n. 8.245, de 18 de outubro de 1991, São Paulo, Saraiva, 1992.

.A Parte Contratual, in M. VIEIRA VON ADAMEK, Temas de Direito Societário e Empresarial Contemporâneos, São Paulo, Malheiros, 2011.

TuHr, Andreas von, Derecho civil: teoría general del derecho civil alemán, trad. esp. Tito Ravá, v. I, t. I, Madri, Marcial Pons, 1999.

Ulhoa Coelho, Fabio, Curso de Direito Civil, vol. III, 6. a ed., São Paulo, Saraiva, 2013.

VAN ORMAN QuINE, Willard, Word and Object, Cambridge, MIT Press, 1960.

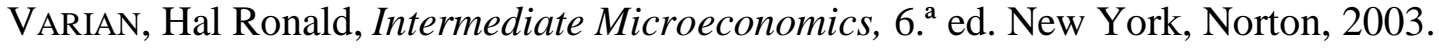

Venosa, Silvio de Salvo, Direito Civil, vol. III - Contratos, 10. a ed., São Paulo, Saraiva, 2010.

VENTURA RIBEIRO, Renato, Aspectos da societas Romana, in Revista da Faculdade de Direito da Universidade de São Paulo, v. 101, jan./dez. 2006.

Vilanova, Lourival, Causalidade e relação no direito. $4^{\mathrm{a}}$ ed., São Paulo, Revista dos Tribunais, 2000.

VoHS, Kathleen D. Making choices impairs subsequent self-control: a limited-resource account of decision making, self-regulation, and active initiative, in Journal of Personality and Social Psychology, v. 94, n. ${ }^{\circ}$ 5, 2008.

WILLIANSOM, Oliver Eaton, The economic institutions of capitalism, New York, Free Press, 1985.

XAVIER, Alberto, Consórcio: Natureza Jurídica e Regime Tributário, Revista Dialética de Direito Tributário, n. 64. 
ZimmermanN, Reinhard, The Law of Obligations - Roman Foundations of the Civilian Tradition, Cape Town/Wetton/Johannesburg, Juta, 1992. 